
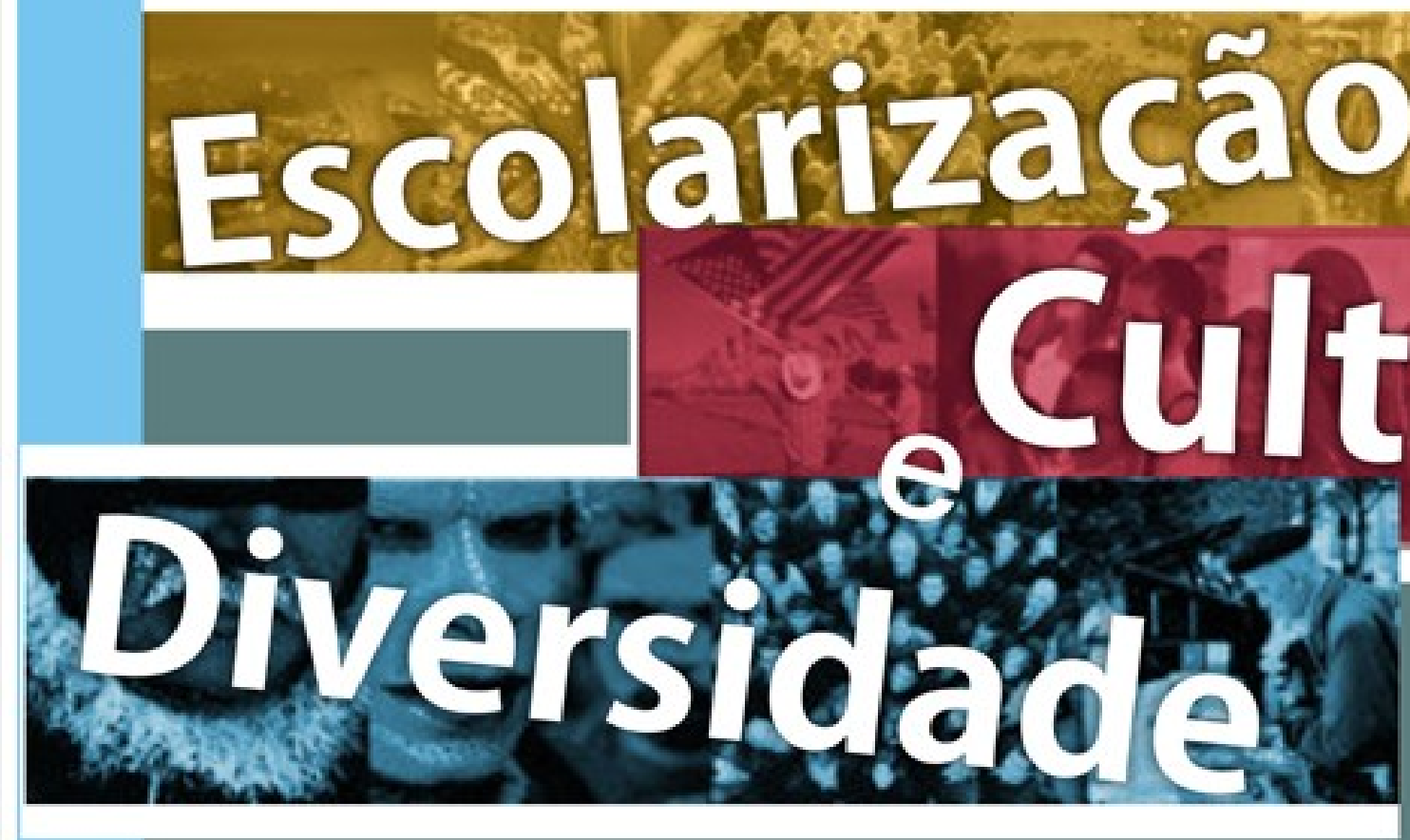

\title{
Percursos Anterculturais
}

ORGANIZADORAS

Josélia Gomes Neves Juracy Machado Pacífico Maria Cândida Müller Maria Ivonete Barbosa Tamboril Marli Lúcia Tonatto Zibetti 


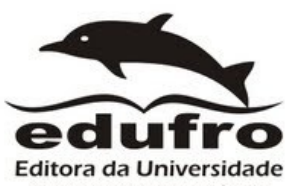

Editora da Universidade Federal de Rondônia

Campus José Ribeiro Filho

BR 364, Km 9,5 - Porto Velho - RO

CEP: $78900-000$

www.edufro.unir.br

edufro.unir@gmail.com 
Organizadoras:

Josélia Gomes Neves, Juracy Machado Pacífico

Maria Cândida Müller

Maria Ivonete Barbosa Tamboril

Marli Lúcia Tonatto Zibetti

ESCOLARIZAÇÃO, CULTURA E DIVERSIDADE.

Percursos Interculturais

$1^{\circ}$ Edição

EDUFRO

Porto Velho - RO, 2013 
Ficha catalográfica - Biblioteca Central da UNIR

E747

Escolarização, cultura e diversidade: percursos interculturais / organizadora Josélia Gomes Neves ... [et all.]. Porto Velho-RO: EDUFRO, 2013. 136 p. : il.

ISBN 978-85-7764-051-5

1. Educação escolar 2. Educação intercultural 3. Diversidade I. Neves, Josélia Gomes org. II. Titulo

CDU: 37.035

Bibliotecária Responsável: Ozelina Saldanha CRB 11/947

Preparo de originais: Autor(es)

Revisão Gramatical: Autor(es)

Revisão de Normas Técnicas: Autor(es)
Capa: Thallisson Lopes

Composição: EDUFRO

Editor: Jairo André Schlindwein

Fundação Universidade Federal de Rondônia

\author{
Maria Berenice Alho da Costa Tourinho \\ Reitora \\ Maria Cristina Victorino de França \\ Vice-Reitora \\ Adilson Siqueira de Andrade \\ Chefe de Gabinete \\ Ivanda Soares da Silva \\ Pró-Reitor de Administração
}

\author{
Osmar Siena \\ Pró-Reitor de Planejamento \\ Jorge Luiz Coimbra de Oliveira \\ Pró-Reitora de Graduação \\ Ari Miguel Teixeira Ott \\ Pró-Reitora de Pós-Graduação e Pesquisa \\ Rubens Vaz Cavalcante \\ Pró-Reitor de Cultura, Extensão e Assuntos Estudantis
}

Conselho Editorial da EDUFRO:

Jairo André Schlindwein (Prof. UNIR), José Lucas Pedreira Bueno (Prof. UNIR), Emanuel Fernando Maia de Souza (Prof. UNIR), Rubiani de Cássia Pagotto (Profa. UNIR), Osmar Siena (Prof. UNIR), Júlio César Barreto Rocha (Prof. UNIR), Marli Lucia Tonatto Zibetti (Profa. UNIR), Sirlaine Galhardo Gomes Costa (Bibliotecária. UNIR), Cléberson de Freitas Fernandes (EMBRAPA), Dante Ribeiro da Fonseca (ACLER).

Depósito legal na Biblioteca Nacional conforme Lei nํㅜ 10.994, 14 de dezembro de 2004.

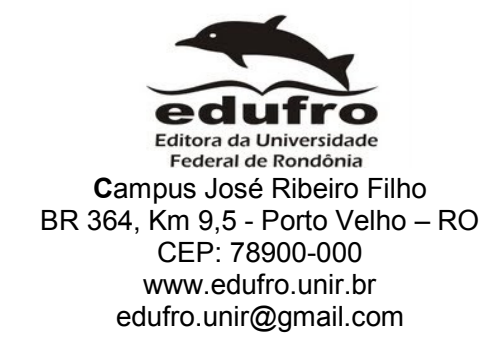




\section{SUMÁRIO}

Página

APRESENTAÇÃO

A PRODUÇÃO DAS DIFERENÇAS PELA ESCOLA

Reinaldo Matias Fleuri

EDUCAR EM TODOS OS CANTOS: POR UMA EDUCAÇÃO INTERTRANSCULTURAL

18

Paulo Roberto Padilha

PRODUZINDO INÉDITOS VIÁVEIS NA ESCOLA PÚBLICA

26

Corinta Maria Grisolia Geraldi

FORMAÇÃO E OCUPAÇÃO PROFISSIONAL DE PROFESSORAS DE EDUCAÇÃO INFANTIL DO MUNICÍPIO DE VILHENA/RO

Juracy Machado Pacífico

CULTURA E CURRÍCULO: PERCURSOS INDISSOCIÁVEIS NO PROCESSO DE FORMAÇÃO CONTINUADA DA PROFESSORA DOS ANOS INICIAIS

Maria Cândida Müller

PROGRAMA DE FORMAÇÃO DE PROFESSORES ALFABETIZADORES: RESULTADOS DE UMA EXPERIÊNCIA DE FORMAÇÃO CONTINUADA

Edna Maria Cordeiro

UM OLHAR SOBRE O CICLO BÁSICO EM ROLIM DE MOURA - RONDÔNIA

Bianca Santos Chisté, Luzenir da Mota Alves

EDUCAÇÃO COMO DIÁLOGO DE SUJEITOS: AS CULTURAS NO ESPAÇO ESCOLAR

Flávia Pansini

EDUCAÇÃO E DIVERSIDADE: DESAFIOS À PRÁTICA PEDAGÓGICA

Marli Tonatto Zibetti

TER, FAZER E PENSAR A EXPERIÊNCIA: UMA SAÍDA EPISTEMOLÓGICA PARA COMPREENDER O COTIDIANO E TODA A SUA DIVERSIDADE

Orestes Zivieri Neto

DIÁLOGO INTERCULTURAL: CURRÍCULO, INCLUSÃO DIGITAL E IDENTIDADE CULTURAL ... Neide Borges Pedrosa

AS POLÍTICAS PÚBLICAS DE EDUCAÇÃO DO CAMPO EM RONDÔNIA: INTERVENÇÃO ESTATAL A SERVIÇO DO IMPERIALISMO

Marilsa Miranda de Souza

A PARTICIPAÇÃO DAS MULHERES CAMPONESAS NO MOVIMENTO SOCIAL DO CAMPO: UM ESTUDO NA REGIÃO DO CONE SUL DO ESTADO DE RONDÔNIA

Maria Ivonete Barbosa Tamboril, Juracy Machado Pacifico, Juliane Oliveira, Klésia Regina Gregória Prudente

O CURSO DE LICENCIATURA INTERCULTURAL NA UNIR: HISTORIOGRAFANDO INTERCULTURALIDADE 


\title{
APRESENTAÇÃO
}

\begin{abstract}
O sonho pela humanização, pela concretização é sempre processo, e sempre devir, passa pela ruptura das amarras reais, concretas, de ordem econômica, política, social, ideológica etc., que nos estão condenando à desumanização. O sonho é assim uma exigência ou uma condição que se vem fazendo permanente na história que fazemos e que nos faz e re-faz. (Paulo Freire) ${ }^{1}$
\end{abstract}

Escolarização, cultura e diversidade: percursos interculturais, como o próprio nome anuncia, é uma obra em que o processo de escolarização é discutido, pesquisado e vivido como experiência cultural caracterizada pela diversidade, principalmente no espaço-tempo de terras rondonienses, cujo percurso intercultural das pessoas que aqui habitam exige que processos educacionais hegemônicos e excludentes sejam desconstruídos e em seu lugar edificados projetos nos quais as diferenças não resultem em desigualdades.

Perseguindo o sonho da humanização dos processos educacionais, a partir de nossa atuação nos cursos de Pedagogia de três campi da Universidade Federal de Rondônia, e de nossos grupos de Pesquisa, a saber: GEP - Grupo de Estudos Pedagógicos (Campus de Vilhena), GPEA - Grupo de Pesquisa em Educação na Amazônia (Campus de Ji-Paraná) e GEPPEA - Grupo de Estudos e Pesquisas em Psicologia e Educação na Amazônia (Campus de Rolim de Moura), buscamos planejar e desenvolver ações conjuntas em favor da democratização do acesso ao conhecimento, tanto para populações tradicionalmente excluídas, quanto para professores e professoras em formação.

Dessa maneira, ao invés de compactuarmos com atitudes de disputa e divisão interna, comuns no espaço acadêmico, procuramos estabelecer um diálogo produtivo entre os/as profissionais dos três grupos citados, atuando de maneira colaborativa na elaboração de projetos de pesquisa, eventos e produção acadêmica. E foi neste contexto que surgiu o Seminário de Educação, evento que está em sua terceira edição cuja temática orientadora interculturalidade - tem atravessado os diferentes trabalhos produzidos pelos membros dos grupos de pesquisa dos três campi, além de permitir o intercâmbio com pesquisadores e pesquisadoras de outras regiões do país. Boa parte das produções dos grupos sobre a temática, bem como os textos dos colaboradores e colaboradoras externos, compõe este livro.

As experiências de formação e pesquisa, vividas no interior dos grupos e também no intercâmbio entre eles, têm permitido que GEP e GEPPEA integrem as atividades do Programa de Mestrado Acadêmico em Psicologia - MAPSI, não só por meio da contribuição das professoras que atuam no curso, mas também por meio da preparação de futuros pesquisadores e pesquisadoras capazes de prosseguir sua formação em nível de Pós-

\footnotetext{
${ }^{1}$ FREIRE, P. Pedagogia dos Sonhos Possíveis. São Paulo: editora UNESP, 2001.
} 
Graduação como evidenciam os cinco mestrandos/as do referido programa, oriundos dos dois grupos citados.

Assim, se "Sonhar é imaginar horizontes de possibilidades;" e se "sonhar coletivamente é assumir a luta pela construção das condições de possibilidade" ${ }^{2}$ convidamos os leitores e leitoras a nos acompanhar neste percurso que em seu ponto de partida não passava de imaginação, mas como sonho coletivo passou a garantir as condições possíveis para que hoje possamos tornar pública a presente obra, construída com o trabalho de muitas pessoas que acreditam na possibilidade de superação da escola que temos pela construção da escola que todos e todas merecemos.

Evidenciando que esta é uma obra produzida pelo esforço coletivo de muitas mentes e mãos, os três primeiros textos, gentilmente cedidos pelos nossos interlocutores externos, discutem de forma didática e consistente, conceitos importantes para o campo da escolarização, abordando, principalmente questões curriculares. Como nos questiona Reinaldo Matias Fleuri no primeiro texto, é preciso que nos perguntemos como trabalhar com a diversidade na escola de forma que esta não seja produtora (discriminatória) de diferenças? E, é possível tratar igualmente os diferentes? Que alterações curriculares são necessárias para superar a homogeneização do currículo incompatível com a diversidade que caracteriza os sujeitos escolares?

Por sua vez, Paulo Roberto Padilha defende uma educação intertranscultural que supõe um currículo que trabalha tanto com as diferenças, quanto com as semelhanças dando ênfase à diversidade cultural no currículo.

Trabalhando com o conceito de inédito viável, inspirada nas idéias de Paulo Freire, Corinta Geraldi compartilha suas reflexões sobre alguns aspectos da experiência de gestão municipal vivida por ela como Secretária de Educação do município de Campinas de 20012004. A análise toma como foco o protagonismo de alunos, o trabalho docente, a organização coletiva do projeto pedagógico e o suporte governamental como indutores e catalisadores da política colocada em ação durante o período.

Os quatro textos seguintes iniciam a divulgação de estudos e pesquisas realizados em Rondônia e tomam por base a formação de professores. O primeiro deles escrito por Juracy Machado Pacífico (GEP), a partir de dados coletados por ocasião de sua pesquisa de doutoramento, analisa o trabalho docente das professoras de Educação Infantil em Vilhena $\mathrm{RO}$, utilizando-se das categorias formação e ocupação profissional.

O trabalho de Maria Cândida Muller (GEP) refere-se a uma proposta de formação de professoras dos anos iniciais do ensino fundamental na área de ensino de matemática, visando à constituição de uma comunidade científica educacional capaz de contribuir para o aperfeiçoamento docente, garantindo aprendizagens que considerem as questões culturais como orientadoras da construção do currículo em ação nas escolas públicas.

O Programa de Formação de Professores Alfabetizadores - PROFA - é o foco da pesquisa apresentada no capítulo 6, na qual Edna Cordeiro (GEP) buscou investigar as contribuições do referido programa ao desenvolvimento da prática docente, analisando em que medida os objetivos que orientaram as ações do Programa de Formação continuada foram efetivamente alcançados.

\footnotetext{
${ }^{2}$ Ana Lúcia Freitas no prefácio do livro FREIRE, P. Pedagogia dos Sonhos Possíveis. São Paulo: editora UNESP, 2001.
} 
O trabalho de Bianca Chisté e Luzenir Alves (GEP e GEPPEA) também toma como ponto de partida uma experiência de formação continuada analisando, a partir dela, as percepções das professoras alfabetizadoras e equipes gestoras de escolas públicas estaduais de Rolim de Moura, sobre a política de organização das séries iniciais do ensino fundamental em Ciclo.

Em outro bloco, temos três produções cujas preocupações estão mais voltadas para o atendimento às diferenças no cotidiano escolar.

No texto Educação Escolar e Cultura: um diálogo de sujeitos, Flávia Pansini (GEPPEA) nos convida a refletir sobre a pedagogia desenvolvida no cenário escolar alertando-nos para a manutenção de práticas que ocultam e desvalorizam as condições de vida de grupos sociais minoritários e/ou marginalizados, a despeito de vivermos um tempo em que os discursos pósmodernos dão grande ênfase às produções sobre multiculturalismo. Assim a autora discute como se apresentam as diferenças culturais no espaço escolar, como a escola lida com essas diferenças e as implicações que se colocam para o estabelecimento de uma prática dialógica.

Marli Zibetti (GEPPEA) problematiza a forma como têm sido entendidas as diferenças no cotidiano escolar e as conseqüências dessas concepções para a produção do fracasso escolar. Utilizando dados de pesquisas desenvolvidas em escolas públicas de Rolim de Moura, apresenta elementos que nos permitem discutir as necessárias transformações no espaço escolar para a construção de uma educação que acolha a diversidade como elemento constitutivo das relações humanas.

A diversidade do cotidiano escolar é objeto de reflexão no texto de Orestes Zivieri Neto (GEPPEA) que, à luz do conceito de experiência, convida o leitor a ter coragem para "alçar o primeiro vôo" em busca de uma maior compreensão das dificuldades enfrentadas pelos docentes em salas de aulas com diferentes necessidades, nem sempre fáceis de serem atendidas. Percebemos aqui a experiência do pesquisador tornar-se parte da experiência dos sujeitos da pesquisa revelando como a inserção respeitosa no cotidiano escolar permite a compreensão da realidade pela ótica daqueles e daquelas que a vivenciam diuturnamente.

Os quatro últimos textos trazem à tona investigações que nos remetem à inserção da tecnologia na formação de educadores indígenas, educação do campo, participação das mulheres camponesas nos movimentos sociais do campo e ainda a preocupação com o acesso da população indígena à escolarização.

Neide Borges Pedrosa (GPEA), a partir da narrativa de uma experiência de inclusão digital com docentes indígenas, levanta alguns questionamentos que orientam seu processo de pesquisa sobre os pressupostos capazes de embasar uma política inclusiva comprometida com a emancipação dos sujeitos envolvidos. E aponta para a necessidade de se trabalhar o acesso às Tecnologias da Informação de maneira crítica considerando-se que elas tanto podem ser utilizadas para a dominação quanto para a humanização, propondo que esse acesso seja promovido por meio de um "diálogo intercultural".

O texto de Marilsa Miranda de Souza (GEPPEA) analisa as relações de dependência do Estado Brasileiro diante da expansão do capitalismo, principalmente em relação às políticas públicas educacionais. A autora analisa os interesses que sustentam os investimentos de agências de regulação multilaterais (Organização Mundial do Comércio - OMC, Fundo Monetário Internacional - FMI, Banco Mundial, etc.) em políticas públicas para a educação do campo em Rondônia. 
A participação das mulheres nas diferentes instâncias da vida social é tema relevante para pesquisadores e pesquisadoras preocupadas com a superação das desigualdades sofridas pelas mulheres historicamente. Desta forma, o texto de Maria Ivonete Barbosa Tamboril (GEP) e colaboradoras discutem, sob a perspectiva de gênero, a inserção das mulheres nos movimentos social e sindical do campo, no Cone Sul de Rondônia, pois é preciso conhecer como se dá a presença dessas mulheres nas instâncias organizativas e deliberativas em uma área profissional em que lhes era negado inclusive o título de propriedade da terra.

Josélia Gomes Neves (GPEA) encerra o livro brindando-nos com um texto que sinaliza o sonho da forma como o destacamos no início desta apresentação: a atuação coletiva em favor da criação de possibilidades. A autora enfatiza a possibilidade de um diálogo intercultural entre a universidade e os povos da floresta, viabilizando-se um encontro a favor não só do reconhecimento das diferenças culturais, mas principalmente da construção de propostas de enfrentamento da diferença, na perspectiva de aprendermos coletivamente.

E por acreditarmos que é possível aprender nesses percursos interculturais que vimos trilhando coletivamente, convidamos vocês, leitores e leitoras a nos acompanharem nessa trilha, domando nossos sonhos, como recomenda Thiago de $\mathrm{Mello}^{3}$, poeta amazonense.

"Sei que é preciso sonhar.

Campo sem orvalho, seca

a fronte de quem não sonha.

Quem não sonha o azul do vôo

Perde o seu poder de pássaro.

[...]

Sonhar, mas sem deixar nunca.

Que o sol do sonho te arraste

Pelas campinas do vento.

É sonhar, mas cavalgando.

o sonho e inventando o chão

Para o sonho florescer."

Rolim de Moura, junho de 2010.

Marli Lúcia Tonatto Zibetti

\footnotetext{
${ }^{3}$ MELLO, T. de. Mormaço na Floresta. 2. ed. Rio de Janeiro: Civilização Brasileira, 1983.
} 


\section{A PRODUÇÃO DAS DIFERENÇAS PELA ESCOLA}

\section{Reinaldo Matias Fleuri}

Sabemos que a escola recebe ano a ano alunos diferentes entre si. Cada um com as suas peculiaridades culturais, étnicas, religiosas, sociais. A idéia de respeitar essa diversidade torna-se incongruente com a proposta de se trabalhar de maneira homogênea, ou seja, com objetivos únicos, currículo determinado. Pode-se considerar que essa é uma especificidade da escola no século XXI das mais desafiadoras, pois pressupõe uma mudança quase que total na organização do currículo em nossas instituições educativas.

Como trabalhar essa diversidade na escola de forma que esta não seja uma produtora (discriminatória) de diferenças? É possível tratar igualmente os diferentes? Levando-se em consideração que seja possível trabalhar um currículo diferenciado, ajustado às peculiaridades de cada aluno, como fazê-lo sem promover (ou chancelar mesmo que implicitamente) a discriminação e a exclusão?

É possível desenvolver estratégias de inclusão em escolas tradicionais, sem mudar suas características de austeridade, de valorização do conhecimento e da organização?

\section{Os desafios da atualidade}

Com o processo de globalização, enfrentamos hoje mudanças contextuais e metacontextuais profundas e radicais. Semelhante às mudanças ocorridas entre a idade média e a moderna. Com a descoberta dos novos mundos, verificou-se que o mundo não se reduz à paisagem conhecida, ao próprio país. Com as descobertas astronômicas de Copernico e Galileu, descobriu-se que a terra não é o centro do universo: não é o sol que gira em torno da terra, mas é a terra que gira em torno do sol.

Hoje, com a mundialização do mercado, das novas tecnologias, dos meios de comunicação e de locomoção, descobrimos que todos estamos ligados a todos, que todo ato individual e local tem repercussões globais e que as mudanças socioambientais globais interferem diretamente na vida e nas opções individuais. $E$ isto produz contradições nos planos econômico, político, social e educativo, que desafiam nosso modo tradicional de ver o mundo.

No plano econômico acentua-se o processo de universalização do mercado capitalista, que se confronta com os modos de produção locais. Por exemplo, a terra, que para as empresas é objeto de exploração e propriedade, é, ao contrário, para os povos autóctones, chamados indígenas, a mãe que sustenta os seres humanos e, por isso, precisa ser cuidada e respeitada.

No plano político, muitos movimentos sociais lutam por defender a equidade de direitos e de oportunidades ao mesmo tempo que o seu direito à diferença pessoal e cultural. 
Boaventura de Sousa Santos expressa esta tensão afirmando que é preciso defender a igualdade quando a diferença nos sujeita e a a diferença, quando a igualdade nos homogeneiza.

No plano social, coloca-se a necessidade de se construir a autonomia dos sujeitos, individuais ou coletivos, ao mesmo tempo que relações sociais de respeito e solidariedade entre os diferentes sujeitos. Individualismo e totalitalismo são dois riscos constantes na busca de construir coesão entre diferentes pessoas e grupos sociais.

Tais desafios se constituem no plano educativo pela necessidade de se desenvolver processos para se compreender os conflitos, no sentido de fortalecer a identidade cultural de cada pessoa e de cada grupo, construindo processos de cooperação entre eles.

De modo geral, portanto, coloca-se a necessidade de se enfrentar os conflitos, de modo a fortalecer as identidades pessoais e culturais, ao mesmo tempo em que construir processos de entendimento e cooperação entre os diferentes grupos sociais. Neste sentido, a relação entre movimentos sociais de diversos matizes, enraizados em contextos diferentes, requer a elaboração de novas linguagens e de novos modelos interculturais à altura da complexidade dos desafios contemporâneos.

Para além da polissemia terminológica e da evidente diversidade de perspectivas que se expressam nas teorias e propostas relativas ao multiculturalismo, interculturalismo, transculturalismo, o eixo conceitual em torno do qual se situam as questões e as reflexões emergentes neste campo, e que caracteriza os mais espinhosos problemas do nosso tempo, é o da possibilidade de respeitar as diferenças e de integrá-las em uma interação que não as anule, mas que ative o potencial criativo e vital da conexão entre diferentes agentes e entre seus respectivos contextos.

\section{Cultura e identidade}

Para compreender a complexidade desta temática, retomemos um conceito chave: a cultura. Clifford Geertz entende a cultura como a totalidade acumulada de padrões culturais, ou seja, de "sistemas organizados de símbolos significantes" com base nos quais os seres humanos identificam as finalidades de suas ações.

Diferentemente dos animais inferiores, cujas fontes genéticas de informação ordenam estreitamente suas ações, o ser humano é dotado de capacidades inatas de resposta muito gerais. Por isso, sua capacidade de ação é muito mais plástica, complexa e criativa. Mas, por isso mesmo, depende de sistemas de controle extracorpóreos para orientar sua ação. A cultura pode ser vista justamente como "um conjunto de mecanismos de controle - planos, receitas, regras, instruções (o que os engenheiros de computação chamam de 'programas') para governar seu comportamento" (GEERTZ, 1989, p. 56).

Do ponto de vista do indivíduo, estes símbolos são dados. Ele os encontra já em uso na comunidade em que vive. Utiliza-os deliberada ou espontaneamente para se orientar na construção dos acontecimentos através dos quais ele vive. E, sobretudo, deles depende para se orientar. Sem a referência a padrões culturais - sistemas organizados de símbolos significantes - o ser humano seria incapaz de governar seu comportamento e sua experiência não apresentaria qualquer forma. A cultura - a totalidade acumulada de tais padrões - é, pois, uma condição essencial da existência humana e sua principal base de concretização específica. 


\section{Interculturalidade e autoconhecimento}

A interação com os outros desafia-nos a entender os significados que eles atribuem a suas ações. A "estranheza" do comportamento de outro nos choca porque a lógica do contexto cultural que determina seu significado é diferente da lógica inerente aos nossos padrões culturais. Para entender o comportamento de outra pessoa, é preciso compreender a lógica da "organização dos símbolos significantes" desenvolvida por seu grupo. Ao mesmo tempo, a compreensão da lógica de padrões culturais diferentes permite, por contraste, entender a especificidade da lógica dos nossos padrões culturais e a relatividade dos significados que atribuímos aos nossos atos. Desta maneira, ao refletir sobre nossas ações sob a perspectiva de outros padrões culturais, podemos descobrir outros significados que nossas próprias ações podem assumir e, com isso, descobrir formas diferentes de orientá-las.

Conversar com os outros - e não apenas falar sobre eles ou para eles - é a condição para desenvolvermos a compreensão dos significados e das estruturas significantes de nossas próprias ações. A compreensão do sentido da ação do outro é uma condição importante para a compreensão dos sentidos de nossa própria ação. A compreensão da lógica de significação, inerente aos padrões culturais de outros grupos, facilita a compreensão da lógica inerente aos nossos próprios sistemas simbólicos de significação. A relação entre culturas é, assim, a condição para o desenvolvimento de cada cultura.

\section{Educação e diálogo entre culturas}

Destas considerações se levanta uma hipótese radical para o campo da educação. Já é sabido que, para o indivíduo, a educação é essencial, como processo de aprendizagem da própria cultura. Sem apropriar-se de padrões culturais vigentes em seu contexto, o indivíduo seria virtualmente incapaz de se orientar e mesmo de sobreviver em sociedade. E "os seres humanos se educam em relação, mediatizados pelo mundo", tendo a própria cultura como mediação (FREIRE, 1975, p. 79). Mas do ponto de vista da cultura como tal, cada grupo social, sem interagir com outras culturas, seria incapaz de compreender a lógica dos próprios padrões culturais, nos quais se baseia para dar sentido à sua vida coletiva. A interação com outras culturas aparece como essencial para a evolução da própria cultura. Assim, parafraseando Paulo Freire, poderíamos supor que as culturas se educam em relação, mediadas pelas pessoas. As pessoas que interagem, individual ou coletivamente, com pessoas de contextos sociais diferentes colocam em questão os padrões culturais próprios e, vice-versa, coloca em cheque os princípios e a lógica que regem a cultura alheia.

\section{Desafios interculturais}

Confrontar-se com estranhos não são relações fáceis e tranqüilas. São relações profundamente conflitantes e dramáticas. A história nos revela que muitas de tais relações entre povos e grupos sociais diferentes têm resultado em guerras, genocídios, processos de colonização e de dominação. Da mesma forma, no interior de grupos e instituições sociais, a interação entre pessoas que se diferenciam por etnia, gênero, geração, cultura, características 
físicas e mentais, produz conflitos e tensões que podem resultar em exclusão ou sujeição. Entender, pois, tais processos de relações interculturais torna-se a condição para, não só compreender as lógicas que conduzem à destruição ou sujeição mútua, mas sobretudo para descobrir as possibilidades criativas e dialógicas das relações entre pessoas e grupos de contextos culturais diferentes.

As relações interculturais também não são relações cujos significados se configuram a partir de perspectivas singulares, individuais, nem se consolidam em pouco tempo. A formação dos padrões culturais e os processos educativos a ela inerentes configuram-se no entrecruzamento paradoxal de muitas perspectivas que, por isso mesmo, constituem-se dinâmica e conflitualmente. $\mathrm{E}$, embora cada ato tenha efeitos educativos, que contribuem para a configuração e transformação dos padrões culturais, estes só se constituem em processos históricos de longa duração. Por isso, a perspectiva intercultural implica em uma compreensão complexa da educação, que busca - para além das estratégias pedagógicas e mesmo das relações interpessoais imediatas - entender e promover lenta e prolongadamente a formação de contextos relacionais e coletivos de elaboração de significados que orientam a vida das pessoas.

Todavia, o estudo e a promoção de relações interculturais só podem se desenvolver a partir das relações interpessoais em sua facticidade histórica. O conhecimento das culturas e de suas inter-relações, objeto principal da Etnografia, implica a "descrição densa" das estruturas significantes a partir das quais cada pessoa, em cada contexto cultural, elabora os significados de seus atos e dos eventos de que participa. A compreensão dos padrões culturais, assim de suas transformações e inter-relações, só evolui com base no estudo atento e minucioso dos significados que cada ato e cada relação de cada sujeito vão assumindo em seu contexto. "Temos que descer aos detalhes, além das etiquetas enganadoras, além dos tipos metafísicos, além das similaridades vazias, para apreender corretamente o caráter essencial não apenas das várias culturas, mas também dos vários tipos de indivíduos dentro de cada cultura, se é que desejamos encontrar a humanidade face a face" (GEERTZ, 1989, p. 65).

Neste sentido, a relação entre pessoas é uma relação entre projetos, propostas, significados. E a relação entre culturas, que ocorre no encontro entre pessoas de culturas diferentes, coloca em questão todos os aparatos simbólicos a partir dos quais cada sujeito se orienta. E é nisso que consiste, ao nosso ver, a relação intercultural. Sujeitos, pessoas de culturas diferentes, que atribuem significados diferenciados às suas ações, ao interagirem colocam em questão não só o sentido de sua ação ou de seu discurso, mas colocam em cheque todo o seu referencial cultural, que lhe permite dar sentidos a cada uma de suas ações, escolhas, palavras, sentimentos.

\section{Escola e desafios interculturais}

Reconhecer que na sociedade, em geral, convivem sujeitos de culturas diferenciadas e que na escola, em particular, as pessoas se educam mediante o diálogo sobre os problemas e conflitos que enfrentam em sua prática, coloca em cheque a concepção homogeneizadora da prática curricular, ainda predominante em nossa sociedade. Segundo este entendimento, o processo de aprendizagem é igual para todos os sujeitos e deve ocorrer de acordo com um único modelo válido de ensino, um padrão de tarefas a ser solicitado, um modelo invariante de seqüências didáticas. Frente a um modelo fixo de aluno, de ensino e de aprendizagem, tudo o 
que aparece como "diferente" passa a ser visto como inadequado, sinônimo de dificuldade ou até mesmo de incapacidade.

\section{A educação intercultural numa perspectiva complexa}

A educação intercultural deve se constituir como um processo educacional, simultaneamente "para todos e para cada um". Superando o modelo de escola da modernidade - que parte de único ponto, desenvolve um único processo didático e chega a um padrão homogêneo de resultados - a educação intercultural busca partir de múltiplos contextos (culturais, subjetivos, sociais, ambientais), promover com as pessoas e grupos, simultânea e articuladamente, diferentes percursos, de modo a produzir múltiplos e complexos impactos sócio-educacionais. Este nos parece, justamente, o desafio intercultural que se coloca nas práticas educacionais: articular a diversidade de sujeitos, de contextos, de linguagens, de ações, de produções culturais, de modo que a potencialização de suas diferenças favoreçam a construção de processos singulares e contextos sócio-educacionais críticos e criativos.

Por isso, é preciso problematizar a organização escolar que se fundamenta exclusivamente na programação de "conteúdos de ensino".

Os "conhecimentos historicamente produzidos pela humanidade", geralmente entendidos como "conteúdos" de ensino escolar, podem - ao nosso ver - se referir ao conjunto de informações e produções culturais codificadas e registradas nas mais diferentes mídias que constituem os imensos acervos de bibliotecas, museus, eventos culturais, monumentos, instituições científicas, culturais, educacionais, dos diferentes povos e nações. Ampliar a acessibilidade a este patrimônio cultural da humanidade implica desde a eliminação de barreiras físicas, psicológicas, sociais, ambientais e culturais, até o desenvolvimento de processos de formação do interesse e da capacitação para o entendimento e recriação das produções culturais. Entretanto, o conhecimento não se restringe ao acervo de mídia em que os registros culturais se configuram objetivamente. O conhecimento se constitui e se reconstitui como processo vivo criado, alimentado ou ressignificado, ou mesmo descontinuado, pela relação entre diferentes sujeitos pessoais e coletivos. O conhecimento se configura como relação viva entre sujeitos em diálogo, conflito e negociação contínua. O patrimônio cultural desenvolvido pela humanidade oferece instrumentos importantes e fundamentais para conferir e elevar a qualidade das relações e ações humanas e sociais. Mas a apropriação crítica e criativa destas "ferramentas" culturais só se faz pela interação intencional e contextualmente sustentada das pessoas entre si. O acesso aos conhecimentos historicamente produzidos, assim como às possibilidades de sua recriação e ressignificação, decorre da efetivação de possibilidades de articulação ativa e orgânica em contextos relacionais inter pessoais e socioculturais.

A concepção estereotípica de "conteúdo", ou dos objetivos básicos de ensino (como se estes tivessem significado fora dos contextos relacionais efetivos entre as pessoas e sociedades), enseja a interpretação quantitativista de acrescentar ou retirar itens de um elenco definido de conceitos, atitudes e habilidades a serem aprendidas. Já o entendimento complexo do conhecimento como "relação entre sujeitos, mediatizados pelo mundo", sugere que a tematização e a definição dos objetivos a serem desenvolvidos por um grupo em seu processo educativo, devem ser deliberados, avaliados e replanejados constantemente pela interação 
entre todos e cada um dos sujeitos envolvidos. Assim, aos educadores compete propor e alimentar as mediações de comunicação entre os sujeitos participantes, mantendo instrumentos democráticos de controle coletivo, para garantir que as propostas de cada um sejam entendidas, negociadas e articuladas com o conjunto das outras propostas, assim como facilitar o desenvolvimento de acesso institucional, e de reelaboração critica e criativa, das informações necessárias para o trabalho educacional.

Desta forma, torna-se possível e necessário trabalhar educacionalmente com as experiências subjetivas e intersubjetivas de professores e estudantes, potencializando as diferenças emergentes, ao mesmo tempo em que a necessária coesão sociocultural, sem que as singularidades sejam anuladas.

Destarte, no processo educativo, é preciso questionar o conceito de aluno "padrão", tomando-se a constituição da diferença como parâmetro da reorganização das escolas. As crianças trazem para a prática pedagógica a necessidade de construção e reconhecimento de sua singularidade. Com efeito, as pessoas são sujeitos que não têm uma identidade fixa, permanente, essencial, mas constituem, singularmente, "um conjunto diversificado de identidades, diante de um eu que não é sempre o mesmo, seguro e coerente, mas um eu cambiante, com cada um dos quais podemos nos confrontar e nos identificar temporariamente. É no contato, na interação entre diferentes sujeitos que estes constroem seus processos de identificação. Por ser relacional, a identidade se constitui de modo fluido, ambivalente, múltiplo.

A relação educativa se constitui, entretanto, na medida em que se desenvolvem mediações (ações, linguagens, dispositivos, representações) que potencializem a capacidade de iniciativa e de interação das pessoas. Por exemplo, nas brincadeiras, ao representar um objeto por outro, a criança se reapresenta e se reconhece. Ela aprende, assim, a simbolizar, dar sentido, significar. Ao mesmo tempo em que a criança descobre a si e ao mundo, ela também descobre e recria esse mundo.

\section{Uma experiência de construção curricular}

As relações educacionais em uma prática escolar pressupõem uma estruturação. Tradicionalmente consideramos que a organização da prática pedagógica se resume à enunciação dos temas a serem ensinados, assim como das técnicas de indução à aprendizagem dessas informações e hábitos. Mas o currículo implica em dimensões e elementos mais complexos. Percebemos isso com muita clareza no desenvolvimento de um curso de formação de educadores do SESI de Santa Catarina, que realizamos recentemente.

A partir do diagnóstico preliminar, assim como do processo de codificação temática vivenciado no primeiro dia do curso, constituíram-se três subgrupos de participantes, que formularam os termos representativos dos desafios e das propostas mais significativos. Entretanto, o desenvolvimento pedagógico encontrou-se num impasse: como organizar tais indicações em um projeto político-pedagógico coerente e consistente. Verificou-se a necessidade de adotar categorias analíticas e procedimentos didáticos para conduzir o grupo neste processo de construção curricular. As categorias analíticas da prática educacional enunciadas no livro Educar para quê? (FLEURI, 2001) indicavam o sujeito, o objetivo, o método, o tema e a avaliação como fatores estruturantes da prática pedagógica. Mas vários enunciados do grupo não quadravam pertinentemente com estes conceitos. Este impasse nos instigou a reformular nossas categorias de sistematização da prática educacional. 


\section{Construção do plano curricular}

Impelidos pela necessidade de criar novas chaves de interpretação e de organização das informações sobre a prática educacional, utilizamos uma estratégia didática baseada na brincadeira popular da "amarelinha" ${ }^{4}$. Esta brincadeira apresenta um percurso com dez casas a serem percorridas pelo jogador. Tomando este jogo como metáfora para organizar as diferentes informações formuladas sobre sua prática, o grupo foi instigado a imaginar dez categorias de organização da atividade pedagógica, portanto cinco conceitos a mais do que se havia pensado até então. Ao tentar formular questões sobre o processo educativo, aquele grupo constatou que o fator estruturante da prática educacional são as pessoas. E que os agentes construtores do processo educacional configuram papéis diferentes, que respondem a questões diferentes. Assim, os sujeitos da educação não são apenas os educadores (quem educa), mas também os educandos (a quem se educa), assim como os que constituem seu contexto familiar e comunitário (com quem se educa). Complexificou-se a concepção de agente da educação, ao se considerar que as pessoas assumem diferentes protagonismos na qualidade de professor, estudante ou parceiro. Embora com papéis diferenciados, são sempre construtores ativos da interação educativa.

Da mesma forma, a concepção da temática (o que se ensina) se reconfigurou ao se considerar as diversas intenções que mobilizam os estudantes a aprender (por que se aprende). Tal formulação permite identificar a articulação entre ensino-aprendizagem. A proposição de temáticas de estudo só se torna significativa e pedagogicamente eficaz na medida em que se articula organicamente com os contextos, com as necessidades e com as intenções que induzem as pessoas a aprenderem.

Também a concepção de metodologia didática se ampliou para além dos métodos (como se educa) e da avaliação (critérios de condução). Ao se considerar a organização dos espaços (onde) e da temporalidade (quando) como estruturante do processo educacional, amplia-se a concepção de método para a de mediação pedagógica. Trata-se de organizar estratégica, política e culturalmente contextos espaçotemporais que instiguem e sustentem a interação crítica, participante e criativa de todas as pessoas incluídas no processo educativo. De tal forma que as pessoas se eduquem, em interação, mediatizadas pelo mundo.

A própria representação gráfica do mapa curricular, seguindo a metáfora da "amarelinha", sugere que a estruturação do processo pedagógico tem como ponto de partida os educadores que interagem com os educandos e com as pessoas que compõem seus respectivos contextos comunitários. A interação educativa é promovida e sustentada por mediações que articulem as intenções dos estudantes com os temas de estudo e que promovam a organização dinâmica dos espaços e dos tempos pessoais e coletivos, assim como o desenvolvimento de estratégias didáticas e de instrumentos para a condução participante do processo pedagógico. Enfim os objetivos, enunciados preliminarmente como metas, se consolidam nos resultados do processo de construção pedagógica.

\footnotetext{
${ }^{4} \mathrm{O}$ jogo da "amarelinha" consiste em pular sobre um desenho riscado com giz no chão, que também pode ter inúmeras variações. Em uma delas, o desenho apresenta quadrados ou retângulos numerados de 1 a 10 e no topo o céu, em formato oval. Em outros países, o jogo assume formas diferentes. No México, por exemplo, a brincadeira é conhecida por "avión" e as casas, mesmo em número de 10 , se estruturam de modo ligeiramente diferente.
} 


\section{Considerações finais}

04.Para que?

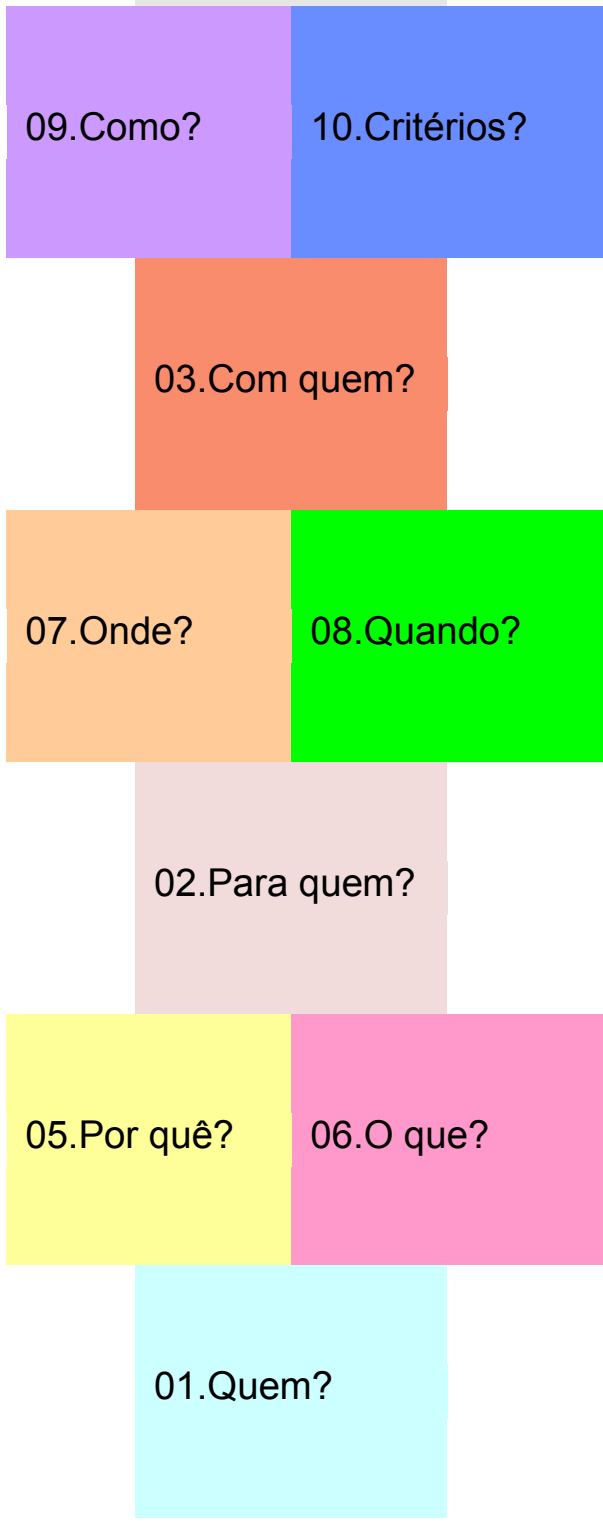

Todo processo educacional implica a interação entre pessoas que constroem processos de identificação e diferenciação sociocultural. A dimensão fundamental e estruturante do processo educativo é constituída pelas pessoas, que se assumem como sujeitos ativos $e$ protagonistas desta prática. Tratar igualmente os diferentes significa considerá-los como autores e co-autores da prática educativa. Tanto os educadores, quanto os estudantes e as pessoas que fazem parte da sua rede de relações próximas devem ser assumidos sujeitos, com papéis sociais diferenciados, mas sempre sujeitos ativos do processo educativo.

O currículo não se reduz à programação dos temas a serem estudados, nem se configura como um processo homogêneo de ensino. É justamente o pressuposto homogeneizador do percurso pedagógico que produz a discriminação e sujeição. Tampouco basta criar processos individualizados de formação ou auto-formação. Se a educação se faz pela relação entre sujeitos, mediatizados pelo mundo, é fundamental desenvolver estratégias interativas para que cada um possa, dinamicamente, explicitar suas intenções, negociar e estabelecer propostas comuns, articulá-las com os contextos históricos, sociais, culturais, a que cada sujeito se vincula, desenvolver atividades e meios pertinentes, avaliando-as e controlando a direção do trabalho conjunto. Na medida em que cada integrante participa ativamente da condução do trabalho coletivo, torna-se mais possível a aprendizagem crítica, rigorosa, criativa, solidária, significativa, prazerosa, transformadora, em suma, educativa.

\section{Referências}

FLEURI, R. M. Educar, para quê. 9. ed. São Paulo: Cortez, 2001.

FLEURI, R. M. (Org.). Educação intercultural: mediações necessárias. Rio de Janeiro: DP\&A, 2003.

FREIRE, P. Pedagogia do oprimido. 3. ed. Rio de Janeiro: Paz e Terra, 1975.

GEERTZ, C. A Interpretação das culturas. Rio de Janeiro: LTC, 1989. 


\section{EDUCAR EM TODOS OS CANTOS: POR UMA EDUCAÇÃO INTERTRANSCULTURAL ${ }^{5}$}

\section{Paulo Roberto Padilha}

A intertransculturalidade supõe, de início, uma educação que trabalha com as diferenças e com as semelhanças culturais, visando a todo tipo de inclusão e às aproximações, às interações e interconexões de experiências educacionais que acontecem na escola e na cidade. A educação intertranscultural, segundo teorizo, dá ênfase à diversidade cultural no currículo de qualquer instituição educacional, e essa diversidade carrega em si mesma diferentes diferenças e múltiplas semelhanças.

Pensando no ensino regular ou formal, a educação intertranscultural contribui para fundamentar a problematizar, criativamente, processos educacionais que estimulem a criação, nas unidades educacionais, de espaços e tempos para o diálogo interativo e comunicativo entre as aprendizagens que acontecem em todas as modalidades e níveis de ensino, e as decorrentes dos processos de educação não formal e informal. Trata-se de educar e tentar superar as dicotomias que resultam da desinformação, do fundamentalismo de todo tipo, das incertezas ou das certezas absolutas no campo das ciências, das artes, da religião, da política. Isso significa caminharmos "entre", "ao mesmo tempo" e "para além" das históricas visões particularistas ou universalistas que resultam de diferentes interesses de pessoas, grupos e instituições, entre os quais, os econômicos, que, por exemplo, negam sistematicamente o diálogo para enfatizar e tornar único o discurso pedagógico, social, cultural e político, subordinando tudo às leis do mercado.

Estamos defendendo o diálogo crítico como alternativa às construções monoculturais em educação para que sejamos capazes de conviver reconhecendo, respeitando e valorizando as diferenças e as semelhanças culturais, pois ambas são fundamentais e presentes em nossa humanidade, conforme as nossas origens, etnias, histórias individuais e coletivas e de acordo com os contextos glocais (global + local), socioculturais, socioambientais, políticos, econômicos - enfim, planetários, em que vivemos.

Nossa perspectiva educacional é trabalhar mais com as conexões (uma coisa e outra) do que simplesmente com a negação (uma coisa ou outra) dos vários conhecimentos e saberes humanos e suas respectivas manifestações socioculturais e socioambientais, relacionais e produtivas, visando a uma educação que promova realmente a inclusão social, humana, com olhar ecossistêmico e considerando todas as formas e manifestações de vida existentes no planeta. Daí, a necessidade de um currículo da escola que trabalhe com e para além da multirreferencialidade humana.

5 Este texto é parte do "sétimo movimento" intitulado "Por uma Educação Intertranscultural" do meu livro Educar em Todos os Cantos: reflexões e canções por uma Educação Intertranscultural" (São Paulo, Cortez/IPF, 2007), que reorganizo e atualizo em setembro de 2008. 
A educação escolar, nessa perspectiva, beberá na fonte várias concepções curriculares, educacionais e políticas, mas não negará aqueles saberes e conhecimentos considerados subjetivos, não fenomenais, difíceis de serem observados sob o ponto de vista dos critérios para que determinados conhecimentos sejam considerados científicos e que, por isso mesmo, foram sendo deixados de lado na história da ciência moderna, tanto pela comunidade acadêmica, como pelas próprias escolas.

Se pensarmos na íntima relação entre educação e cultura, estaremos, então, procurando superar o trabalho monocultural muitas vezes realizado pelos profissionais da educação, entre os quais me incluo, que deixa de lado a riqueza e a diversidade cultural e multicultural presente em nossas vidas, nas nossas salas de aula e nos outros espaços de convivência social e cultural como é o caso das comunidades, onde se manifestam com intensa força ricas experiências de educação popular que pouquíssimas vezes têm sido aproveitadas pela escola regular.

Apresento aqui uma primeira característica da educação intertranscultural: procurar ter sempre uma visão de totalidade das ações propostas nos processos educativos e evitar se conformar, por exemplo, com a prática do projetismo, das ações imediatas, que dispensam um processo de formação do sujeito sem que ele seja capaz de estabelecer profundas relações com outros sujeitos e entre diferentes manifestações do conhecimento e da sabedoria acumulada pela humanidade.

Uma segunda característica marcante da educação, e, portanto, do currículo intertranscultural, é valorizar o trabalho interdisciplinar quando este cria condições para o encontro entre diferentes disciplinas ou áreas do conhecimento e quando propõe uma ação curricular emancipadora das pessoas. Parte-se, como observamos, das disciplinas ou das áreas do conhecimento para trabalhar o currículo da escola.

Ao trabalharmos na perspectiva da intertransculturalidade, os nossos pontos de partida não são exatamente as disciplinas, as áreas do conhecimento ou as ciências. Os nossos pontos de partida são as pessoas, os coletivos humanos e as relações que eles estabelecem entre si e com o mundo em que vivem. Portanto, começamos o processo educacional, na perspectiva da educação intertranscultural, pelo reconhecimento das histórias de vida, das culturas e das identidades, semelhanças e diferenças culturais entre as pessoas.

As relações humanas é o que nos interessa no início do processo pedagógico, justamente porque se trata de educar PA+ra a convivência, para as inter-relações e para as interconexões entre as pessoas e entre elas com o planeta, nas suas mais complexas, mais singelas e mais dinâmicas dimensões.

Seremos tanto mais intertransculturais, quanto mais nos colocarmos do ponto de vista da outra cultura, resgatando, respeitando e valorizando as várias etnias e, a partir disso, conhecendo melhor a nossa própria cultura e as nossas múltiplas identidades. $E$ isso não significa apenas trabalhar, por exemplo, com grupos de pessoas que se encontram pela primeira vez em determinados contextos socioculturais de migração. Isso significa reconhecer, no cotidiano de nossas relações, que todas as pessoas são, em alguma dimensão, diferentes e semelhantes às outras, em determinados aspectos, e essa situação nos ajuda a construir uma relação educacional mais humanizada, mais condizente com os interesses, com as experiências, com as necessidades e com as características de cada cultura. 
A diferença e a semelhança cultural, por exemplo, étnica, social, de gênero, geracional, religiosa, entre outras, estão presentes na nossa vida cotidiana, nas salas de aula, nas creches, nos espaços públicos, nos ambientes diversos que freqüentamos para trabalhar, para o lazer, para qualquer tipo de convivência social, começando pela própria família. Por isso, é que precisamos reconhecê-las até mesmo para melhorar e humanizar a nossa própria convivência humana, bem como nossas relações com todas as formas de vida do planeta. Com isso estamos afirmando que ao falar de educação intertranscultural, não podemos nos restringir aos conflitos multiculturais nascidos dos movimentos migratórios, como acontecia nos primórdios dos estudos sobre multiculturalismo e sobre diversidade cultural, como ainda hoje acontece.

Os tempos, os espaços de relação e de contatos culturais, principalmente levando em consideração as novas tecnologias da comunicação, são outros, muito mais complexos e amplos, exigindo novas formas de enfrentamento do fenômeno multicultural e de suas manifestações mais diretas, como a violência, o preconceito, os conflitos sociais, raciais, étnicos, sexuais, religiosos, econômicos, políticos, entre outros.

A educação intertranscultural viabiliza e propõe atividades transdisciplinares, tentando transcender o conhecimento científico, dando ênfase à cultura como referência primeira na relação com outras formas e manifestações do conhecimento e da sensibilidade humana.

Observemos que Paulo Freire trabalhava com os "Círculos de Cultura" e não com círculos de educação, porque cultura e educação estão em relação, mas a primeira é muito mais ampla do que a segunda ${ }^{6}$.

Quando me refiro à cultura, utilizo como referência o conceito antropológico formulado por Antônio Custódio Gonçalves:

\begin{abstract}
totalidade social mais vasta que a própria sociedade [...] que abrange não só os sistemas normativos como sistemas de relações sociais, mas também os sistemas de representações, de expressão e de ação, por meio dos quais a totalidade social é apreendida nas características distintivas dos comportamentos individuais e das populações artesanais, artísticas, econômicas, políticas e religiosas dum grupo ou duma sociedade. Nesse sentido, a cultura compreende o conjunto, socialmente significativo, dos comportamentos, dos saberes, do saber-fazer e do poder-fazer específicos dum grupo ou duma sociedade, adquiridos por um processo contínuo de assimilação e de enculturação e transmitidos à comunidade (GONÇALVES, 1997, p.117-8).
\end{abstract}

Importante é acentuar as aprendizagens e as vivências humanas no processo de ensino e aprendizagem, e não apenas os conhecimentos historicamente acumulados com os quais a escola tanto trabalha. Desta forma, estimulamos o diálogo, o conflito, a diversidade cultural, o reconhecimento das diferenças, das diferenças dentro das diferenças, das identidades dos sujeitos envolvidos, visando tornar sempre possível a ampliação do diálogo e à melhor qualidade de vida das pessoas envolvidas nesses ciclos vitais de ensino e de aprendizagem.

Quando falamos de currículo e de educação intertranscultural, não estamos nos limitando à educação formal, até porque, para nós, a educação acontece em todos os cantos,

6 Sobre "Círculos de Cultura", sugiro a leitura do item 2.4 - "Círculo de Cultura e Currículo, no meu livro Currículo Intertranscultural: novos itinerários para a educação" (PADILHA, 2004, p. 160-182). Ver também o livro de Carlos Rodrigues Brandão, intitulado "A educação como cultura" (1985, p. 139), no qual "toda educação é cultura". 
em todos os momentos, em todas as horas da nossa vida e em todos os espaços em que vivemos e convivemos. Daí também a idéia de um Mundo Educador, que valoriza a cultura, a ciência, a política, enfim, as várias manifestações do conhecimento, do sentir e do saber da humanidade, acumulado e por vir. Procurar aprender a utilizar as várias linguagens artísticas, as várias formas de expressão simbólica e representativa, material e imaterial, presentes em nossas vidas cotidianas, é uma forma de avançar na direção da construção de uma educação intertranscultural.

A palavra currículo, quando associada a processos educacionais, tem sido historicamente considerada sinônimo de conteúdos programáticos que fazem parte de uma determinada "grade curricular"7 que a unidade educacional deve trabalhar com seus alunos e com suas alunas. A dificuldade de se estabelecer um currículo que seja mais apropriado à educação na "era da informação", rumo à "era do conhecimento" - e nós diríamos, na direção da "era de humanização" e da tessitura de novos saberes ${ }^{8}$ - reside, talvez, na dicotomia entre teoria e prática que os estudos sobre currículo revelam, sobretudo quando se trata de definir quais conhecimentos deverão ser estudados na escola e como isso será feito.

Quando dicotomizamos teoria e prática, estamos diante de uma concepção fragmentada de ciência e de currículo, que opera com lógicas excludentes. Daí, por exemplo, a dificuldade de concretizar projetos interdisciplinares, pois, ao mesmo tempo em que se busca a troca e a cooperação entre as disciplinas, o nível de especialização delas cria uma verdadeira "fronteira disciplinar, com sua linguagem e com os conceitos que lhe são próprios, isolando a disciplina em relação às outras e em relação aos problemas que ultrapassam as disciplinas" (MORIN, 1999, p. 28).

Quando nos deparamos com propostas curriculares que, explícita ou subliminarmente, consideram algumas ciências superiores às outras, uma cultura melhor que a outra e que, assim, hierarquizam saberes e subordinam as relações humanas no processo de ensino e de aprendizagem, estamos diante de um determinado modo de entender e de dar sentido ao conhecimento do e sobre o mundo, que é por oposições (ou/ou). Não é essa a nossa lógica.

O currículo intertranscultural compreende o mundo com base nas relações dialógicas que nele se estabelecem e que também podem se dar por conexões (e/e).

Se pensarmos especificamente na sala de aula, podemos exercitar os contextos favorecedores do diálogo aprofundado sobre a nossa cultura, sobre as nossas origens, sobre os nossos sonhos, desejos, expectativas e qualidade de vida, de trabalho, de aprendizagens e sobre as nossas visões de mundo. Poderemos então resgatar a capacidade de criticar, de problematizar, de planejar juntos o que será estudado, de entender a relação do que se aprende nos contextos educacionais com as discussões relacionadas à gestão democrática ou compartilhada das instâncias de decisão coletiva na escola ou na comunidade.

Em síntese, na perspectiva da educação intertranscultural, quando tratamos de currículo formal ou não formal, devemos:

- Partir das relações e da cultura das pessoas.

- Criar espaços e tempos de encontros na escola, na cidade, no bairro, na comunidade,

7 Sugiro também superarmos a lógica da "grade" associada ao currículo, pois ela nos dá a idéia de prisão, de limites, de censura, de fragmentação do conhecimento. Falemos, simplesmente, de currículo da escola ou da unidade educacional.

8 Num momento em que discutimos a possibilidade de "mudar o mundo sem tomar o poder" (HOLLOWAY, 2003) e em "mudar o mundo transformando o poder" (SANTOS, 2005). 
onde o diálogo entre as pessoas é estimulado.

- Realizar a "leitura do mundo" do contexto, problematizando a realidade.

- Refletir sobre os diferentes significados dos múltiplos sentidos do real.

- Promover a tentativa de reconhecimento dos símbolos e das representações culturais, materiais e imateriais da realidade que nos cerca.

- Vivenciar experiências de aproximações e de afastamentos identitários conforme o grau de comunicação que as nossas linguagens nos permitem.

Esse movimento relacional procura desvelar quais são as visões de mundo e de natureza humana que cada pessoa traz na sua experiência cultural, educacional, social, política e espiritual. E, assim, processualmente, criam-se as possibilidades para o autoconhecimento individual, pessoal, intra, interpessoal e coletivo.

Diferenças e semelhanças reconhecidas se desdobram nos seus aspectos pedagógicos, filosóficos, históricos, antropológicos, sociológicos, psicológicos, lingüísticos, políticos, econômicos etc.

A educação e o currículo intertranscultural nascem, assim, de um processo cultural e educacional que visa à conectividade humana, ao reconhecimento de relações híbridas da descoberta dos "entre-lugares", instâncias nas quais fundimos os nossos múltiplos saberes e procuramos superar o monoculturalismo e o "daltonismo cultural" (STOER; CORTESÃO, 1999). Procuramos novas cores, novos sabores e novos sentidos para o ato de educar.

O conteúdo da educação intertranscultural inclui também, por exemplo, todas as dimensões da organização do trabalho educacional ao qual estamos vinculados, seja ele numa escola, numa creche, numa associação de moradores, num salão paroquial, na favela, na fábrica, no sindicato, no clube de futebol, na escola de samba, em qualquer lugar onde a educação acontece de forma intencional. É por isso que é importante participar do projeto ecopolítico-pedagógico, da gestão democrática/compartilhada da escola, da valorização do exercício da cidadania pelas crianças desde a infância e da decisão sobre as parcerias comunitárias e sociais que organizam e colaboram com o trabalho educacional, sociocultural e socioambiental que estamos desenvolvendo.

É também por essa razão que avaliar dialógica e continuadamente a qualidade sociocultural e socioambiental da nossa própria formação humana é fundamental para que estejamos sempre pensando e reavaliando como se dão as relações humanas e de aprendizagem.

O objeto do conhecimento numa organização curricular intertranscultural considerará os referenciais da nossa práxis (união dialética entre teoria e prática) e, por conseguinte, selecionará bibliografia, registros e sistematizações das experiências, bem como materiais didático-pedagógicos compatíveis com as exigências próprias do processo educacional aqui proposto. São também conteúdos de aprendizagem, nessa perspectiva, as mais recentes descobertas das ciências, em todas as suas áreas - da biologia, da bioética, da física quântica, da cibernética, do imaginário, das neurociências, da psicopedagogia, da semiótica, da lingüística, da neurolinguística, da antropologia, das sociologia política, das pedagogias, do direito, enfim, das ciências humanas, naturais e produtivas, associadas às novas tecnologias e às artes, que favorecem os processos educacionais e o avanço das próprias ciências e de outras formas de expressão e sentir humanos.

Como vemos a educação intertranscultural, para um mundo educador, é fator primordial para viabilizarmos o que hoje chamamos de educação integral, que também não se refere 
apenas a determinados espaços ou tempos de aprendizagem, como se a educação tivesse que acontecer apenas dentro dos calendários fixos, seriados ou ciclados, mas que favorece a mobilidade, a ampliação dos espaços da comunidade que já são potencialmente educacionais, mas que, muitas vezes, são ou estão ociosos. Trata-se de abrir a mente e o coração para as diferentes possibilidades de ensino e de aprendizagem que formos capazes de realizar, como sujeitos criativos, emocionais, sensíveis, criativos, políticos e culturais que somos, e de buscarmos articular saberes a partir de projetos integrados e integradores, de ações e parcerias intergeracionais, intersetoriais e interculturais.

A Educação Integral depende, naturalmente, de um projeto coletivo bem elaborado, que saiba aproximar cuidadosamente estado e sociedade civil, interconectando o interesse de todas as pessoas e instituições para que se ofereça, na cidade, uma educação de qualidade sociocultural e socioambiental, unindo sonhos coletivos, projetos intersetoriais e intersecretariais. $E$ isso depende de decisão, de iniciativa individual e coletiva, de arregaçar as mangas, de criticar e de sempre acreditar que, pela nossa ação, o que fazemos na educação e na sociedade em que vivemos pode ser sempre melhor realizado.

Valorizar cada sujeito desse processo também é fundamental, de forma que alunos e alunas, familiares, professores e professoras, coordenadores e diretores escolares, funcionários das unidades educacionais envolvidas e das instâncias governamentais participantes - além de toda a organização da sociedade civil - movimentos sociais, igrejas, sindicatos, clubes, bibliotecas, teatros etc. saibam exatamente o que está para acontecer na educação da cidade. Por isso, a comunicação, a transparência, a veiculação de informação de todos os lados é exigência inicial para dar visibilidade tanto ao que se pretende fazer, quanto ao que já foi feito, até porque, se não se sabe o que está acontecendo, como podem as pessoas e instituições se associar e defender algum projeto? A comunicação é essencialmente educativa.

Trabalhar com a formação continuada dos sujeitos para viabilizar a Educação Integral é outra exigência desse processo, compondo uma verdadeira sinfonia em torno do projeto que se quer construir, o que depende de vários músicos, vários sujeitos, maestros e instrumentos diríamos, recursos e condições humanas, financeiras e materiais concretas.

Educar integralmente significa, primordialmente, educar para garantir direitos e contribuir para a promoção de todas as formas de inclusão. Temos quase sempre pensado e trabalhado na perspectiva dos oprimidos, visando à não exclusão, procurando contribuir para a superação da expulsão das pessoas que, direta ou indiretamente, já estão inseridas nos processos e nos projetos participativos. Mas não basta. Ir além disso significa trabalhar também pela inclusão, em todos os sentidos, das crianças, jovens, adolescentes e dos adultos que estão fora da escola, que não estão matriculados nas instituições oficiais de ensino nem, tampouco, nos processos educacionais não formais.

A Educação Integral ultrapassa aquela noção apenas parcial de ser um processo inclusivo para os alunos que poderiam evadir-se da escola. Ela significa, acima de tudo, termos o cuidado intenso com a inclusão em todos os níveis, e não apenas com a inclusão de pessoas deficientes ou com "necessidades especiais de aprendizagem". Significa inclusão e participação com perspectivas de emprego, trabalho e renda, com continuidade dos estudos e com políticas socialmente justas, culturalmente inclusivas e humanamente compatíveis com as Cartas das Declarações Mundiais de Direitos - Humanos, da Terra, dos Fóruns Sociais 
Mundiais, dos Fóruns Mundiais de Educação, das Cartas e Declarações Mundiais do Meio Ambiente, da Agenda 21, só para dar alguns exemplos.

Uma educação intertranscultural não limita professores e alunos na escola nem fora dela. Não significa educar só no bairro ou apenas na escola. Não dicotomiza atividades lúdicas e atividades formativas, estudos e jogos, brincadeiras e pesquisa. Não prende nem professores nem oficineiros em grades curriculares ou grades de atividades, que muitas vezes são propostas como se fossem uma forma diferente de educar, mas que mantém não apenas a lógica das "grades" como também a dicotomia entre currículo e atividade, como se uma coisa não estivesse sempre íntima relação e interação com a outra.

Nessa perspectiva educacional, são importantes para a formação humana as experiências das diversas gerações que "se educam em comunhão", pois professores e alunos fazem parte do currículo e, por conseguinte, dos estudos realizados em sala de aula, no bairro, na cidade, das relações humanas, pessoais, interpessoais, intergeracionais, intergeracionais estabelecidas em todos os tempos históricos e também as que estamos construindo hoje nos nossos espaços de convivência, sem deixar de considerar as influências que terão em nosso futuro comum.

Para concluir, destacamos alguns princípios, valores e orientações que podem também facilitar a nossa práxis relacionada à educação e ao currículo intertranscultural: visar à educação permanente de todas as pessoas que participam e atuam direta ou indiretamente na escola, para o exercício da cidadania planetária; questionar todo e qualquer discurso, informação, conhecimento e processo de ensino e de aprendizagem que se autodenomine neutro ou que se apresente numa perspectiva homogeneizadora; valorizar o intercâmbio e o diálogo entre os grupos culturais e seu mútuo enriquecimento, questionando e buscando a superação de qualquer manifestação que pretenda, sob qualquer alegação, naturalizar o predomínio de uma cultura sobre a outra; trabalhar os processos de reconstrução do conhecimento sempre visando à justiça social e à humanização da educação, estimulando a aprendizagem como forma de intercâmbio e partilha; respeitar e reler, criticamente, os diversos documentos surgidos nas amplas discussões nacionais e internacionais, como demanda dos povos, bem como incentivar também a permanente atualização crítica dos referidos princípios declarados nessas cartas, de acordo com as exigências e necessidades das sociedades contemporâneas, respeitados os limites éticos da convivência humana justa, pacífica, sustentável e emancipadora.

A Educação Integral na perspectiva intertranscultural é tema de grande relevância, principalmente se pensarmos nas essências de uma educação que tenha qualidade sociocultural e socioambiental em pleno Século XXI. É por isso que, com base nos referenciais teóricos aqui abordados, estamos iniciando o "Programa de Educação para a Cidadania Planetária: formação de educadores/as, estudos e pesquisas sobre Educação Integral na perspectiva Intertranscultural e Transdisciplinar", para aprofundar nas dimensões práticas e teóricas, criando referencialidades no âmbito da educação e do currículo.

Para isso, também inspirados na obra de Paulo Freire e em outros autores, temos por objetivo constituir equipes transdisciplinares de educadores e de outros profissionais no intervalo entre a pessoa, educação e a cultura, voltados a pensar e a realizar, dialogicamente, a Educação Integral como processo de formação humana que se fundamenta na Educação Intertranscultural, visando à crescente construção de cidadanias planetárias. Com base nas relações, diferenças e semelhanças que os constituem, as equipes de trabalho devem pensar 
e propor a difusão de ações e materiais didático-pedagógicas fundados na transdisciplinaridade e nos processos assentados em relações objetivas, subjetivas e intersubjetivas entre educadoras e educadores formais e não formais, realizando de maneira efetiva um fazer educativo que busque articular os diferentes saberes, conhecimentos e valores e criando novas referencialidades nas áreas da Educação e do Currículo.

\section{Referências}

BRANDÃO, Carlos Rodrigues. A educação como cultura. São Paulo: Brasiliense, 1985.

FREIRE, Paulo. Educação como prática da liberdade. 14. ed. Rio de Janeiro: Paz e Terra, 1983.

GONÇALVES, António Custódio. Questões de Antropologia Social e Cultural. São Paulo: Edições Afrontamento, 1997.

MORIN, Edgar. Complexidade e transdisciplinaridade: a reforma da universidade e do ensino fundamental. Tradução: Edgard de Assis Carvalho. Natal: EDUFRN, 1999.

PADILHA, Paulo Roberto. Currículo Intertranscultural. Novos itinerários para a educação. São Paulo: Cortez: Instituto Paulo Freire, 2004.

- Educar em todos os cantos - reflexos e canções por uma educação intertranscultural. São Paulo: Cortez: Instituto Paulo Freire, 2007.

STOER S. R.; CORTESÃO, Luiza. Levantando a pedra: da pedagogia inter/multicultural às políticas educativas numa época de transnacionalização. Porto: Afrontamento, 1999. 


\section{PRODUZINDO INÉDITOS VIÁVEIS NA ESCOLA PÚBLICA ${ }^{9}$}

\section{Corinta Maria Grisolia Geraldi}

\section{Possibilidades ensejadas pelo conceito de Inéditos Viáveis em Paulo Freire}

Trabalhar o conceito de inédito viável em Paulo Freire como potente para fugir das simplificações do papel da escola numa sociedade complexa, capitalista, globalizada e neoliberal, sem abrir mão da flexibilidade, fluidez e estrutura cambiante em que se inserem as práticas sociais e culturais, bem como a produção teórica nesses tempos difíceis de sonhos desfeitos ${ }^{10}$, é a proposta deste texto.

O presente trabalho explicita algumas das hipóteses que informaram a gestão pública da educação municipal de Campinas pelo Governo Democrático e Popular, no período de 2001-2004, quando fui Secretária de Educação. Elas sinalizam o protagonismo de alunos (crianças, jovens e adultos) na produção da ESCOLA VIVA mediado pelo trabalho docente autoral, pela organização coletiva do projeto pedagógico e pelo suporte governamental (pedagógico, material, administrativo, legal e financeiro) que age como indutor e catalisador dessa política que tem, em cada uma das 200 unidades educacionais municipais de Campinas ${ }^{11}$, sua expressão singular.

Afastar-me, por um tempo determinado, do "protegido" ambiente acadêmico para exercer o cargo de Secretária de Educação de um município brasileiro com um milhão de habitantes, participando da gestão política de um governo democrático e popular (liderado pelo Partido dos Trabalhadores), não se constituiu em decisão fácil. Significou refazer aprendizados acadêmicos, desconstruindo e revisitando nossas leituras de tempo histórico, marcado pela necessidade de "distanciamento" (temporal e espacial) do objeto empírico, para poder incluir o aprendizado de trabalhar com o tempo de governo. Este deslocamento é imprescindível não só para alguém se incluir nele, como também, e principalmente, para participar de sua gestão,

\footnotetext{
${ }^{9} \mathrm{O}$ presente texto sintetiza as principais idéias desenvolvidas na abertura do I/ Seminário Internacional de Educação, para sinalizar a política educacional ESCOLA VIVA implementada pela Secretaria Municipal de Educação de Campinas, SP, 2001/2004. Em grande parte este artigo consta no meu artigo (GERALDI, 2004) presente no livro organizado por Geraldi, Riolfi e Garcia (2004). Nem este artigo nem o livro supra citado pretendem representar a descrição e análise dos inúmeros programas e projetos desenvolvidos na Rede Municipal de Ensino de Campinas e FUMEC, período 2001/2004, cuja explicitação precisa e deverá ser elaborada e analisada, pela caligrafia de seus autores.

${ }_{10}$ A propósito, ver Geraldi, J.W.(2007). Problematizar o futuro não é perder a memória do que há de vir.

${ }^{11}$ A Rede Municipal de Educação de Campinas possui cerca de 200 Unidades Educativas, sendo 156 de Educação Infantil e 44 de Ensino Fundamental completo (modalidades regular e supletiva), com cerca de 70 mil estudantes e 5 mil profissionais, organizados em duas instituições municipais, dirigidas conjuntamente: Secretaria Municipal de Educação (SME) e Fundação Municipal de Educação Comunitária (FUMEC).
} 
colocando-se em condições de poder intervir nesse objeto através de ações políticas.

Neste período, portanto, foi necessário associar, mesmo com muitas mediações e provisoriedades, o mundo cultural, temporal e espacialmente constituído, o mundo da política com o mundo da academia para a (re) (des) formulação de políticas públicas capazes de responder aos desafios da desigualdade social que ocorre de forma contundente na cidade de Campinas.

Significou, antes de tudo, aprender a "lidar" com um tempo e espaço específicos, numa conjuntura dada, contextualizado historicamente pela mundialização excludente, que, inexorável, toma-se incapaz de impedir a existência, às vezes fluida, outras nem tanto, de novos movimentos sociais e culturais que sinalizam para o descongelamento de uma certa ideologia que se dispôs a fixar o fim da história ${ }^{12}$.

Campinas tem inscrito no seu território, marcas de desigualdades que ficam veladas pela impessoalidade das médias estatísticas. Por um lado, Campinas possui um IDH ${ }^{13}$ invejável, acima de 0,8; é considerada a cidade-pólo da América Latina em ciência e tecnologia não só por suas Universidades ${ }^{14}$, mas também pelos inúmeros Institutos públicos de Pesquisa ${ }^{15}$, e laboratórios e empresas de produção de Ciência \& Tecnologia $^{16}$. A Região Metropolitana de Campinas representa $10 \%$ do PIB nacional. Nessa mesma Campinas de um milhão de habitantes, vivem cem mil desempregados e 37 mil analfabetos. Segundo a Fundação SEADE, dados de 2000 mostravam que Campinas é a terceira cidade do estado de São Paulo em analfabetismo juvenil e jovens fora da escola (São Paulo e Guarulhos a precedem). O Mapa da Vulnerabilidade Social de Campinas ${ }^{17}$ mostrou que convivem na nossa cidade chefes de famílias com diferença de rendimento de quase 500 vezes e, nesses mesmos bairros, diferenças de anos de escolaridade de 93 vezes, sinalizando as verdadeiras causas da violência a que estão submetidas às grandes cidades do terceiro mundo.

Por outro lado, em 2001 o Governo Democrático e Popular assume o Governo de uma cidade falida: sua dívida, depois de devidamente auditada, equivalia a três orçamentos anuais. $\mathrm{Na}$ educação, 10 mil crianças na fila de espera por uma vaga em creche, que era e é a demanda mais explícita da população de Campinas na agenda eleitoral.

Não tivemos a pretensão - nem apostamos nisso enquanto governantes de uma cidade - de realizar a democracia social e econômica, através das políticas públicas no âmbito municipal, entre elas, a educacional, o que denotaria, no mínimo, ingenuidade. Porém, compreender os processos de exclusão a que estão submetidos os estudantes das escolas públicas municipais de Campinas, buscar dar visibilidade às suas existências, bem como buscar alternativas de inclusão, por provisórias que fossem, ou seja, considerá-los como parte dos problemas a enfrentar, foi uma diretriz estratégica.

Nossa pretensão é explicitar a tese de que é possível trabalhar no bojo dessas

\footnotetext{
${ }^{12}$ Ver sobre o tema, entre outros, Gentilli e Sader (2000); Boneti (2000); Freire (1996).

13 Índice de Desenvolvimento Humano.

${ }^{14}$ Em especial, a Unicamp.

${ }^{15}$ Tais como o Instituto Agronômico, ITAL, EMBRAPA, CPQD, entre outros.

${ }^{16}$ Tal como o Laboratório Síncroton.

${ }^{17}$ A referência utilizada pelo Mapa da Vulnerabilidade Social de Campinas é a utilizada pelo IBGE Instituto Brasileiro de Geografia e Estatística - no Censo Populacional Decenal (neste caso o de 2000), bem como nos PNADs -População Nacional de Amostragem por Domicilio (a cada ano). Nesse caso, a unidade territorial de referencia é denominada UTB - Unidade Básica de Território.
} 
contradições com a produção de "inéditos viáveis" ${ }^{18}$, permitindo a construção do avesso à exclusão e à barbárie. Através do trabalho coletivo, tecemos pelo avesso a ESCOLA VIVA pela participação de crianças, jovens e adultos, com suas diferenças, na de novos caminhos e inserções capazes de fazer com que Campinas se "re-territorialize" no bojo dos novos atores sociais, antes 'invisíveis', mas que também querem deixar suas marcas.

ESCOLA VIVA se inscreve no movimento dos projetos e práticas educacionais progressistas que vêm se realizando no Brasil, a partir dos 80 , após a ditadura militar e especialmente nos municípios, tal como o Movimento de Reorientação Curricular (cidade de São Paulo - gestão Paulo Freire), Escola Plural (Belo Horizonte), Escola Candanga (Brasília), Escola Cabana (Belém), Escola Cidadã (Porto Alegre), para sinalizar as mais conhecidas. Procuramos produzir uma síntese própria que conjugasse essas experiências, avaliações e dificuldades com as histórias e caminhos da própria Rede Municipal de Campinas ${ }^{19}$.

Partimos do princípio segundo o qual, para explicar a pedagogia da ESCOLA VIVA, é necessário realizarmos o caminho inverso ao da pasteurização da escola que temos nesses tempos de neoliberalismo e de barbárie. Cumpre observar que corro o risco aqui ao utilizar o vocábulo "escola", mesmo compreendendo o quanto ele pode ser redutor, uma vez que tentamos, o tempo todo, desconstruir o sentido "escolástico" da escola, tal como o descreve Freinet (1995), como o da tradição da rotina, do já feito, do já dado, do hegemônico, da obediência, da pasteurização e homogeneidade.

Tentamos desconstruir pela produção coletiva. Assim, a ESCOLA VIVA não só tenta produzir desvios a essa tradição 'escolástica', como também, em parte, busca certos deslocamentos, de aspectos dos projetos progressistas praticados com significados e já elaborados previamente, para que o novo, o vivo, as diferenças tivessem lugar e se compusessem com o que foi previamente consolidado e fixado. Além disso, o novo assusta e a prudência da professora (LIMA, 2003) compromete nosso pouco tempo de governo para 'mexer' corações e mentes.

Com diferentes táticas, os profissionais da educação, no trabalho cotidiano realizado nas escolas, ou escondem, total ou parcialmente, no que apostam e fazem, ou "se perdem", "rejeitam" ou "resistem" ao novo, tendendo voltar à pasteurização anterior.

Percebemos e estudamos esses 'caminhos' percorridos por docentes no GEPEC ${ }^{20}$, através de vários encontros de estudos, seminários e pesquisas realizadas com ou por professores e professoras da rede pública de ensino, em diferentes cidades (incluindo Campinas) e estados brasileiros ${ }^{21}$. É o caso de inúmeras propostas interessantes que acabam "não pegando", porque representam muito mais as apostas e os trabalhos elaborados por

${ }^{18}$ Expressão utilizada por Paulo Freire. Ver, entre outros, Freire (2001), denominado Pedagogia dos sonhos possíveis.

${ }^{19}$ Por questão de espaço/tempo, deixa-se de abordar neste texto os inúmeros problemas e desafios enfrentados no encaminhamento da situação funcional dos profissionais da educação, as disputas por modelos de gestão, a sindicância por emissão fraudulenta de certificados de Cursos de Especialização lato sensu, as disputas de projetos de carreira docente, os concursos públicos realizados, as inúmeras ações na justiça. Para completar, a degradação dos espaços públicos (180 prédios 'detonados'), encarnando a barbárie produzida pela política de Estado Mínimo na cidade, Estado e país, inseridos nos movimentos neoliberais globais.

${ }^{20}$ Grupo de Estudos e Pesquisas sobre Educação Continuada, da Faculdade de Educação/ UNICAMP.

${ }^{21} \mathrm{Ver}$, entre outras, as pesquisas de Lima (2003), Menegaço (2004), Garcia (2002), Messias (2000), Furgeri (2001), Dickel (1996), Pereira (2003), Ribeiro (2001), Ferreira (2004), Braga (1996), Chaves (2000). 
grupos políticos hegemônicos (das secretarias de educação, de grupos de intelectuais ou das universidades) do que dos que as constroem cotidiana e coletivamente.

É para evitar isso que A ESCOLA VIVA pretende ser compreendida como em gestação constante, incluindo as pluralidades que compõem seus processos de produção, com seus tempos, espaços e pessoas que procuram inovar na forma de preenchimento dos significados. É também por isso que A ESCOLA VIVA não se construiu a partir de uma proposta pronta e acabada. Ao contrário, ela indicia uma concepção pedagógica e epistemológica que não se fixa nos limites e marcos do conhecimento moderno. Ou seja, sem desconsiderá-los, buscamos neles incluir como 'conhecimento legítimo' as diferentes expressões artísticas, as diferentes culturas e linguagens, os diferentes fazeres e saberes que são produzidos, individuais ou coletivamente, nos espaços educativos da cidade e, usualmente, ficam à margem do 'conhecimento' e da 'cultura' oficiais (APPLE,1997), especialmente das escolares. Para obtermos uma compreensão analítica mais densa do que está em gestação, precisaremos de novos tempos e novas abordagens epistemológicas capazes de auxiliar a compreensão de tais processos, que não cabem em formas pré-concebidas, muito menos em avaliações parametrizadas. Considerando o locus a partir do qual estamos tratando a ESCOLA VIVA, quer nos parecer que a abordagem multirreferencial para compreensão dos fenômenos educacionais poderá ser de grande valia, já que pretende preservar sua complexidade ${ }^{22}$.

Procuremos tratar alguns dos processos desencadeados, advertindo que a versão aqui produzida está marcada pelo lugar e pelo momento político de quem a escreve. Ou seja, é provável que o foco, as referências, as ênfases fossem outras, se outros fossem seus escritores, uma vez que a ESCOLA VIVA supõe esse jogo aberto, rizomático, com as dores, delícias e críticas de assumi-las, especialmente quanto à falta de controle/regulador externo e único ${ }^{23}$, avaliação comum, que a parametrize, com objetivo de participação de ranking (oficial ou oficiosamente) e outros que-tais. Essa referência política está informada pelas análises feitas das reformas educacionais neoliberais (de 1995 para cá) que, via de regra, propõe-se a "descentralizar", mantendo o controle através de processos de regulações, tais como provas externas padronizadas, com maior ou menor sofisticação na sua elaboração ${ }^{24}$. Procuremos explicitá-la.

\section{Situando espaços e tempos}

Campinas traz em sua bandeira a fênix, uma ave que ressurge das cinzas e consegue alçar vôo, resgatando a dimensão de altura. Também tendo sido assim a educação de Campinas. Desde 2001, temos insistentemente lutado a favor da vida, contra a violência, a degradação e omissão do Estado; a favor dos espaços públicos, na defesa dos Direitos das Crianças e Adolescentes de Campinas, dos portadores de deficiências, dos afrodescendentes, mulheres, grupos sexuais, dentre outros. Para isso foi preciso redesenhar/compreender/incluirse cuidadosamente num complexo emaranhado de problemas, e deficiências de ordem material (prédios e materiais), organizacional (anomia como regra) e humana (desorganização

\footnotetext{
${ }^{22}$ A esse respeito ver Martins, 2004, p.85-94.

${ }^{23}$ Optamos por não aceitar as regulações tais como previstas nas análises das abordagens de educação neoliberais e naturalizadas como 'verdadeiras', inclusive, em projetos progressistas. Por isso a Escola Viva supõe um processo de avaliação que supere tais referências e poderão ser melhor compreendidas no artigo de Freitas et al.

${ }^{24}$ A esse respeito ver Popkewitz e Pereyra (1994) e Apple (2000). 
das vidas profissionais), contando com preciosos tesouros:

1. A própria vida, que luta contra a morte, representando as crianças e jovens, bem como seus pais, os grupos organizados no entorno da escola, que teimosamente estavam ou queriam entrar nas unidades educacionais da Rede Municipal de Campinas e aí deixar suas marcas de vida e crescimento;

2. Os diferentes Conselhos (sejam os 200 Conselhos de Escola, sejam os Conselhos gerais da Educação, sejam ainda os demais Conselhos que representam diferentes segmentos e lutas da sociedade civil organizada), pouco valorizados em governos anteriores, mas que, junto com as demais organizações da sociedade civil, procuravam representar a todos e todas (crianças, jovens, portadores de deficiências, comunidade negra, mulheres da periferia, idosos, entre muitos outros) na busca de seus direitos e visibilidade; e

3. Os profissionais da Educação, em suas diferentes especificidades, que reivindicavam seus direitos e a possibilidade do trabalho coletivo e autoral, bem como o resgate do Estado de Direito nas relações de trabalho com o Município, para que pudessem cumprir seu papel histórico e educativo.

Esses 'tesouros' foram aliados a um projeto político de governo, eleito pelo povo de Campinas para 2001/2004, liderado pelo Partido dos Trabalhadores (PT), com o lema que marcou seu governo e a gestão na educação: coragem de mudar. Nada foi gratuito ou fácil. Essa "coragem de mudar" custou o assassinato, nove meses depois de ter sido empossado no cargo, do prefeito eleito Antonio da Costa Santos ${ }^{25}$. Foi um duro período de luto, mudanças na equipe de governo, aliadas às dificuldades oferecidas pela desorganização e degradação da máquina pública, pela "naturalização", tão em voga, de redução do papel do Estado, especialmente o ligado às políticas públicas.

À morte - do Toninho prefeito, e dos muitos Toninhos (jovens, homens e negros, em sua grande maioria) de nossa cidade - ao 'estado mínimo' para as políticas públicas, das escolas sempre-iguais - contrapropusemos a vida, alteridade e incompletude - por isso ESCOLA VIVA - que sugerem novos horizontes de possibilidades (para e das crianças, jovens, bem como de grupos subordinados socialmente, tais como negros, mulheres, portadores de deficiências), expressas nas artes, nos saberes, nos conhecimentos, segundo diferentes culturas. Este princípio orientador não poderia ser expresso num programa ou política educacional previamente delimitado e delineado, porque a defesa da alteridade e da incompletude implica necessariamente que cada uma das 200 Unidades Educacionais se singularize e torne diferentemente presente, em seus próprios projetos pedagógicos, a diferença que encorpa as possibilidades, sem igualar-se uma a outra Unidade Escolar, desejo sempre persistente dos controles e das implantações de políticas previamente desenhadas. Muita vida nas escolas foi reorganizada nesse curto período que consiste um mandato, quando as referências são mudanças culturais e estruturais. Esta reorganização nos mostra:

- Escolas com vontade de serem felizes, fortalecendo as autorias dos trabalhos individuais e coletivos;

- As pessoas se reaproximando da escola como espaço de vida;

- O aparelho público da educação (seus prédios, materiais em geral, mas especialmente,

${ }^{25}$ Toninho do PT, como era chamado. Coube, então, à Vice-Prefeita Izalene Tiene, em circunstâncias trágicas, assumir a liderança do processo iniciado por ambos. 
pedagógicos, seus instrumentos legais e seu financiamento) se reorganizando para dirigir o melhor de si na construção do caminho inverso.

À inevitável visão fragmentária que é experimentada por aqueles e aquelas que viveram de perto tais reorganizações, gostaria de contrapor um olhar 'multirreferenciado', para compartilhar com o leitor não apenas a imobilidade aparente deste texto, mas para sinalizar/indicar algumas imagens, momentos cuja realização possibilitou a leitura de fragmentos desse processo. Alguns desses momentos foram os eventos criados para (nos) mostrarmos uns aos outros e para a cidade, com o objetivo de indicar no que e como é gasto o dinheiro público em educação. Assim surgiu o projeto Escola Viva, Presente! ${ }^{26}$, realizado em 2002, 2003 e 2004. Neles tivemos a oportunidade de observar, emocionados, alguns exemplos tocantes de inclusão: o belíssimo espetáculo das bailarinas em suas cadeiras de rodas, o ritmo contagiante dos meninos com deficiência visual no batuque do Hino Nacional Brasileiro, enquanto outro grupo o expressava através do corpo a alegria de jovens e adultos podendo ver seu trabalho exposto em lugar de prestígio social (como foi, para eles e elas, o Ginásio de Esportes da Unicamp, local onde ocorreu o primeiro evento, em 2002).

A alegria pela auto-estima conquistada pelos jovens tendo voz e vez nas escolas, durante e no final de semana, através das oficinas organizadas no programa "A Escola é Nossa" premiado por promover a paz e solidariedade, ao produzir vínculos do bairro e dos jovens com a escola, tanto através de cursos de Informática \& Cidadania como através de oficinas de batuque, poesia, artes circenses, teatro, brake, rap, grafite, skate, entre outros. Os resultados dessas diferentes manifestações culturais trabalhadas nas escolas eram apresentados em eventos públicos da Secretaria e da Prefeitura; a Rádio Comunitária produzida em uma escola e totalmente dirigida pelos estudantes.

O livro produzido por um grupo de professores num espaço semanal de formação continuada, remunerada, coordenado por um professor da própria Rede, como resultado de dois anos de estudos e pesquisas do grupo sobre a história de Campinas. A produção de professores da rede, organizada em dezenove volumes de texto eletrônico a ser disponibilizada até o final do ano, com o financiamento do MEC/FNDE.

É muito difícil selecionar, para marcar presença neste texto, extratos desse movimento que já advirto, é incompleto, e não se propõe a fazer uma análise crítica de sua qualidade e visibilidade no cotidiano das aulas. Mas podemos afirmar que no horário curricular ou na sua ampliação, com professores remunerados para tal, milhares de processos foram desencadeados. Por exemplo, as crianças negras e brancas brincando com muitas bonecas negras; as tantas apresentações frenéticas de Hip Hop feitas por jovens estudantes das periferias, quer agora tinham na escola, um espaço de vivência para além de seu tempo curricular e da supervisão necessária de professores/as; o orgulho dos meninos da Febem ao terminarem seus cursos de informática e cidadania (na mesma turma em que funcionários municipais, entre os quais, a própria guarda municipal), e receberem um certificado com a emoção de quem tem a chance de realizar este gesto pela primeira vez.

\footnotetext{
${ }^{26}$ Eventos criados nesta gestão para possibilitar que a própria Rede Municipal, pais e familiares dos alunos, os próprios profissionais da SME/FUMEC, tivessem uma visão mais aproximada desse todo, com todos os limites que supõe uma aparição em um evento. Nesses eventos, cada escola era convidada a apresentar algo que estivesse elaborando, seja em painéis, quadros ou vídeos, ou a apresentação no palco de poesias, danças e outras possibilidades artísticas.
} 
No outro lado, temos os estudantes apresentando os resultados de suas pesquisas em vários espaços (ou contextos) como, por exemplo, os I e II Seminários de alunos na Unicamp no projeto "Ciência na Escola" - ocasião em que alunos de ensino fundamental puderam expor o conhecimento produzido em suas pesquisas, sobre a história dos moradores de seus bairros, questões ambientais, obre a história dos moradores de seus bairros e as condições de infra-estrutura, bem como resgatando sistematicamente as culturas, saberes dos lugares de onde seus pais vieram (muitos de Minas, Bahia, Pernambuco e Paraná), entre tantos outros momentos ímpares em que presenciamos a vida, teimando em resistir mesmo em situações concretas tão difíceis. As mais de 20 fanfarras das escolas, a criação da Fanfarra Municipal de Campinas, os grupos de danças envolvidos no Prodança Criança Escola, que reúne 4500 crianças e jovens das escolas municipais de Campinas, que dançam desde o balé clássico até os ritmos contemporâneos, advindos das diferentes culturas brasileiras ou as danças de rua, em especial, o brake e o street dance. A Capoeira na Escola incluída como possibilidade curricular, como atividade cultural e educativa, cujos orientadores são mestres selecionados a partir dos saberes e da organização dos conhecimentos culturais acumulados pelos afrodescendentes, fazendo jus à sua ancestralidade.

Estas produções, iluminadas pela diversidade temática, pelos lugares ocupados e focalizados, pelos olhares dirigidos, quase todos com uma profunda vinculação com o cotidiano das escolas, mostram que a proposta política de que todo/a educador/a seja uma pesquisador/a de sua prática é, nos dias de hoje, muito mais do que um sonho. Já vem se construindo como realidade. Talvez um dos méritos da ESCOLA VIVA seja 'dar a ver' um trabalho, supostamente inexistente ou quase invisível, não reconhecido por muitos espaços institucionais, historicamente presos à naturalização da prática como espaço do fazer, do já feito, do já visto, do sempre-igual, que aceitam consciente ou tacitamente a afirmação da incapacidade de pensar daqueles que 'fazem'. Ao contrário, aqui estão sinalizadas a força e o potencial de produção dos profissionais da educação pública básica de nosso país, e em especial de Campinas. Assim como a verba trimestralmente distribuída e destinada com critérios sociais, para manutenção cotidiana das escolas é decidida e controlada pelo Conselho da Escola, também nestes Conselhos são aprovados e avaliados os Projetos Pedagógicos de cada Unidade Educativa, que por sua vez testemunham que em cada canto de nossa cidade há um/a educador/a, um grupo, uma escola..., coletivamente produzindo e sistematizando saberes sobre os intrincados meandros do ensinar e do aprender, e do (com/como) viver.

$\mathrm{Na}$ impossibilidade de mostrar singularmente a riqueza e singularidade de cada trabalho, registro o testemunho de algumas das muitas lições aprendidas.

\section{O vivo do trabalho com fragmentos e provisoriedades}

A todo o momento vemos a vida explodir nas condições mais adversas: é a árvore que se sustenta no barranco por suas raízes retorcidas, é a pequena planta que busca a superfície através da fresta no cimento, são os liquens que teimam em florir nas regiões mais geladas ou os cactos que transformam folhas em espinhos, para reter a água escassa.

Essa energia estende-se e intensifica-se no mundo humano, fortalecido pela esperança. Apesar de sua aparente fragilidade, a vida sempre teima em persistir. Ela não se contém, jorrando sempre em sua energia criadora. Assim também na escola coisa bonita! 
ESCOLA VIVA significa esse movimento de resgate e construção do novo, não a partir do previamente definido, mas pelo esforço de construir espaços e projetos, nem sempre aqueles que pensamos serem os melhores, mas que são os melhores para aqueles que o elaboram e o executam, projetos que fortaleçam a vida das crianças e jovens em primeiro lugar, organizando cada Escola a partir de seu entorno (SINGULARIDADE), buscando sempre um lugar especial e melhor para aquele e aquela que já sofrem a discriminação ou formas de exclusão na sociedade (INCLUSÃO RADICAL), assegurando que as decisões sejam tomadas com a participação de todos os interlocutores de uma escola viva, especialmente dos pais e da população do entorno da escola, viabilizando a participação no projeto de educação de seus filhos, controle social e transparência das verbas da educação (PARTICIPAÇÃO DINÂMICA).

Esse caminho construído coletivamente tem se nutrido da vontade política de resgate da cidadania. Seguindo o ensinamento dos alunos de Barbiana (1977) nada mais injusto que distribuir partes iguais a pessoas desiguais, procuramos ampliar a heterogeneidade das possibilidades de saberes, conhecimentos e culturas, com oportunidades inversamente proporcionais a que nossa sociedade injusta possibilita na dura luta pela sobrevivência. Por este motivo, incluímos diferentemente as diversas formas de expressão, seja pelo aprendizado nos conhecimentos disponíveis na biblioteca, Internet ou com os educadores e educadoras de cada escola, seja pela pesquisa e estudos temáticos e produtores de conhecimentos pelos próprios estudantes que se tornam mais sujeitos de seu processo de aprender porque se inserem no mundo como protagonistas, seja pelas diferentes formas de expressão artística, acessibilidade, condições de aprendizagem viva, de acesso às culturas sem discriminação. Essa dimensão de escola, que aqui chamamos de viva, só se efetiva se contar, paralelamente, com a formação contínua dos profissionais da educação que também resgate o sentido da autoria dos educadores e educadoras, da produção coletiva do projeto pedagógico da escola, a partir de novos modos de organização do trabalho pedagógico e de sua avaliação.

Para colaborar na construção de uma ESCOLA VIVA é necessário construir um olhar através do qual seja possível ter acesso ao que se passa dentro de cada uma das escolas, com diferentes possibilidades de ver, focalizar, a partir do que as pessoas dão a ver, para além daquilo que as Secretarias gostam muito de mostrar como grandes projetos ou como marcos teóricos conceituais freqüentemente já mortos nos papéis em que se inscrevem. Não temos percebido convenientemente os movimentos que ocorrem nos espaços e tempos não documentados, nas presenças civis dentro da escola: trata-se de como professores e professoras, alunos e alunas, funcionários e funcionárias, pais e mães se apropriam da escola.

São processos que não estão nos documentos e, por esse motivo, para pesquisá-los será necessário conviver na escola de modo a poder olhar para aquilo que foge para aquilo que é o peculiar, que escapa do dito, do não dito, do pronunciado, do que se estabelece como uma polifonia num suposto silêncio homogeneizado dos documentos. É exatamente no que quebra a hegemonia totalizante que está a vida da escola. Ezpeleta e Rockwell (1986) podem fornecer algumas referências para compreender as multiplicidades da história e as construções peculiares de cada escola da rede municipal que devem ser levadas em conta quando pensamos na construção do projeto político pedagógico. Esse olhar vai além do estatal, do instituído, do homogeneizado nos documentos oficiais.

Considero o projeto pedagógico como uma metodologia de trabalho que supõe três momentos sucessivamente consecutivos: da crítica à proposta, da proposta à ação, da ação à crítica,... Trata-se de um movimento que pode começar pelo que gera o maior consenso 
possível do grupo num determinado momento histórico, por aquilo que está nos preocupando no momento, bastando que haja consenso de um grupo dos envolvidos e este fato vivo que são a vontade e a possibilidade de batalhar por uma solução.

Não devemos sequer tentar fazer tudo ao mesmo tempo. Essa vã tentativa nos dá uma sensação de impotência, enquanto nos anima começar por aquilo que se pode fazer, pelo que a gente vem fazendo e que não tem tido tempo de refletir. É importante nos reunir em grupo, tentar explicitar uma crítica da situação existente, sempre complexa e complicada e, a partir dela, construir urna proposta, uma pauta das ações importantes para realizar.

Estabelecida a proposta, passa-se à ação, ou modifica-se a ação até então realizada. Nossa prática mostrou que esta é a passagem mais difícil. Quase todos se reúnem para fazer a crítica, para imaginar corno poderia ser diferente do hoje. Da crítica à proposta muita gente se mobiliza. Entretanto, para transformar esse planejamento no cotidiano da sala de aula é muito difícil. Só quem está na prática sabe o quanto isso é difícil! Cada um vê o novo de um jeito, quer realizar do seu modo, faltam parcerias, o corre-corre dificulta a busca desses jeitos diferentes, que são sempre mais complexos.

O movimento seguinte é o da ação à crítica. A partir do que foi realizado é necessário fazer sua avaliação para ver o que ocorreu, onde estão os nós. Por esse motivo, o momento de registro do realizado é mais relevante do que a descrição anterior. O registro do feito tende a mostrar melhor a peculiaridade, a singularidade. O projeto não é documento, não é plano. Projeto é esse processo que, como já foi dito, é peculiar, é singular, é movimento. É necessário tomar muito cuidado para não burocratizar o projeto pedagógico.

Projeto pedagógico, para nós, é o instrumento de construção da intencionalidade, da função social da escola. Ele é centrado no ensino, dado que essa função é nossa missão primeira, mas está vinculado aos processos de pesquisa e de intervenção. É por isso que um projeto pedagógico não pode ser definido à distância daqueles que o executam, e nem mesmo podem ser uniformizados, porque as pessoas são diferentes, têm histórias diferentes e fazem diferença. É preciso aprender com estas diferenças, especialmente quando se está no exercício de um mandato, cujo tempo não é o tempo da criação, o tempo da paciência, o tempo da espera. No entanto, se não soubermos conviver com este tempo, só aparentemente construímos mudanças nas escolas.

\section{Compartilhando com o leitor um convite à vida...}

Para terminar, trago uma reflexão do escritor e filósofo francês Albert Camus (1989) que já qualificava o momento que estamos vivendo de absurdo. $O$ autor relata que para ele este absurdo era tão grande que achou que a melhor coisa a fazer era suicidar-se.

Decisão tomada, Camus passou a refletir o que aconteceria caso a levasse a cabo. $O$ que este ato geraria? Interrogou-se, portanto, como seria visto socialmente esse protesto dele contra o absurdo da vida. Chegou, então, à conclusão que com seu ato ele não expressaria um protesto convenientemente, mas sim acrescentaria ainda mais absurdo ao absurdo. Chegou, então, à enunciação dessa frase: "Tiro assim do absurdo três conseqüências, que são: a minha revolta, a minha liberdade e a minha paixão. Pelo jogo da consciência, transformo em regra de vida o que é um convite à morte" (p.80).

Então, nesse momento tão absurdo, em que tudo nos convida à morte, eu convido a todos nós para transformar em regra de vida esse convite à morte que o neoliberalismo fez ao 
nosso país: a luta pela vida precisa continuar, o assassinato de jovens da periferia ainda não foi estancado, mas ao invés da contabilidade da morte (quantos jovens assassinados, em comparação com o mês, ano anteriores) em que cada dor de perda é sepultada na impessoalidade dos números, propomos fazer a contabilidade da vida: quantas crianças e adolescentes foram redimidos à esperança, pelo trabalho persistente, criativo e amoroso de nossos educadores? Quantas crianças com necessidades especiais recobraram pouco a pouco sua cidadania? Quantos talentos para a arte, a literatura, as ciências, a filosofia, foram desenterrados e valorizados? Quantos sorrisos surgiram pelo esforço de conhecer e ser recompensado com a consciência de cidadania que amplia horizontes?

\section{Referências}

APPLE, M. Conhecimento oficial. Petrópolis: Vozes, 1997.

Mercados, padrões e desigualdades na educação: lições sobre como criar desigualdades no ambiente escolar. In. AZEVEDO et al. (Org.). Utopia e Democracia na Educação Cidadã. VII Seminário Internacional de Reestruturação Curricular. Porto Alegre: Editora da Universidade - UFRGS e Pref. Mun. de Porto Alegre, 2000, p. 87-108.

BARBIANA. Carta a uma Professora pelos rapazes da Escola de Barbiana. 3. ed. Lisboa: Editorial Presença, 1977.

BRAGA, Á. J. P. Do Mobral ao computador: a implantação de um projeto de informática educativa na educação de jovens e adultos. Campinas, Dissertação de Mestrado: Faculdade de Educação, Unicamp, 1996.

CAMPINAS, SP. Mapa da vulnerabilidade social de campinas. Elaborado e editado em CD Rom pela Secretaria Municipal de Assistência Social, Governo Democrático e Popular de Campinas, São Paulo, 2004.

CAMUS, A. O mito de Sisifo. Ensaios sobre o absurdo. Rio de Janeiro: Guanabara, 1989.

CATTANI, A. D. Fórum Social Mundial. A construção de um mundo melhor. Porto Alegre, Petrópolis: Editora da Universidade / UFRGS, Vozes, Unitrabalho, Corag e Veraz Comunicação, 2001.

CHAVES, S. A construção coletiva de uma prática de formação de professores de ciências: tensões entre o pensar e o agir. Campinas: Tese de Doutorado: Faculdade de Educação, Unicamp, 2000.

DICKEL, A. A produção de um grupo de professoras na produção do trabalho docente. Programa de Mestrado da Faculdade de Educação da Unicamp, 1996. Mimeo.

ESTABLET, R.; BAUDELOT, C. L'école capitaliste en France. Paris: Maspero, 1971.

EZPLETETA, J.; ROCKWELL, E. Pesquisa participante. São Paulo: Cortez: Autores Associados, 1986.

FERREIRA, G. M. Cooperação e democracia na escola: construção de parcerias no cotidiano escolar como formação continuada. Campinas-SP, Dissertação de Mestrado: Faculdade de Educação, Unicamp, 2004.

FREINET, C. Para uma escola do povo. São Paulo: Martins Fontes, 1995.

FREIRE, P. Pedagogia da autonomia. Rio de Janeiro: Paz e Terra, 1996.

Pedagogia dos sonhos possíveis. São Paulo: Ed UNESP, 2001.

FREITAS, L. C. et. Al. Dialética da inclusão e da exclusão: por uma qualidade negociada e emancipadora nas escolas. In: Corinta G. Geraldi; Claudia R. Riolfi e Maria de F. Garcia. 
(Org.). Escola Viva: elementos para a construção de uma educação de qualidade social. Campinas: Mercado de Letras, 2004, v. , p. 61-88.

FURGERI, D. K. P. Do enorme ao pequeno, do dizer à escuta, do prescrever à leitura: lugares de desconstituição de uma orientadora Pedagógica. Campinas: Dissertação de Mestrado, Faculdade de Educação, Unicamp, 2001.

GARCIA M. F. A produção do conhecimento na escola pública: o projeto ciência na escola. Campinas. Tese de Doutorado: Faculdade de Educação, Unicamp, 2002.

GENTILLI, P.; SADER, E. (Org.). Pós-neoliberalismo II - que Estado para que democracia? Petrópolis: Vozes, 2000.

GERALDI, C. M. G.; RIOLFI, C. R.; GARCIA, M. F. (Org.). Escola viva - elementos para a construção de uma educação de qualidade social. Campinas: Mercado de Letras, 2004.

GERALDI, C. M. G. Escola Viva: política educacional por uma escola contra a barbárie. In. GERALDI, C. M. G.; RIOLFI, C. R.; GARCIA, M. F. (Org.). Escola viva - elementos para a construção de uma educação de qualidade social. Campinas: Mercado de Letras, 2004, p. 35-60.

GERALDI, J. W. Problematizar o futuro não é perder a memória do que há de vir. Revista ECOS, Cáceres, ano V, n. 5, p. 67-70, 2007.

GRAMSCI, A. Os intelectuais e a organização da cultura. 2. ed. Rio de Janeiro: Civilização Brasileira,1978.

LIMA, M.; Emília. C. C. Sentidos do trabalho mediados pela educação continuada em Química. Campinas, Tese de Doutorado: Faculdade de Educação, Unicamp, 2003.

MARTINS, J. E. Contribuições epistemológicas da abordagem multireferencial para a compreensão dos fenômenos educacionais. In: Revista Brasileira de Educação. Rio de Janeiro: Anped, Mai/Jun/Jul/ Ago, No. 26, p. 85-94, 2004.

MENEGAÇO, R. C. C. Lições das descontinuidades: fragmentos de tempos e espaços compartilhados na formação da educadora. Campinas: Dissertação de Mestrado: Faculdade de Educação, Unicamp, 2004.

MESSIAS, M. G. M. Aventurando-se no conhecimento: a construção de uma partitura "porvir". Campinas, Tese de Doutorado: Faculdade de Educação, Unicamp, 2000.

PEREIRA, I. A. A desconstituição de uma professora a partir da reflexão do próprio trabalho pedagógico. Ou, da provisoriedade das certezas pedagógicas. Campinas, Dissertação de Mestrado: Faculdade de Educação, Unicamp, 2003.

POPKEWITZ, T.; PEREYRA, M. Estúdio comparado de lãs prácticas contemporâneas de reforma de la formacion del profesorado en ocho países: configuraciôn de la problemática y construcciôn de una metodologia comparativa. In. POPKEWITZ, T. (Org.). Modelos de poder y regulación social en Pedagogía. Barcelona: Ed. Pomares-Corredor, 1994. p. 15-91.

RIBEIRO, R. M. E. Etnias e educação: trajetórias de formação de professores frente à complexidade das relações étnicas no cotidiano escolar. Campinas. Tese de Doutorado: Faculdade de Educação, Unicamp, 2001. 


\title{
FORMAÇÃO E OCUPAÇÃO PROFISSIONAL DE PROFESSORAS DE EDUCAÇÃO INFANTIL DO MUNICÍPIO DE VILHENA/RO
}

\author{
Juracy Machado Pacífico
}

\section{Introdução}

A leitura de alguns autores e autoras (CODO, 1999; NÓVOA, 1999; ESTEVE, 1991; 1999; SCHÖN, 1992; CONTRERAS, 2002; FREITAS, 2002; TARDIF; RAYMOND, 2000; 2003; OLIVEIRA, 2004, entre outros) nos mostra que o trabalho docente é analisado a partir de categorias que poderiam ser assim organizadas: formação profissional, carreira docente, ocupação e, ainda, o mal-estar docente.

A primeira categoria, a formação profissional, refere-se aos níveis e modalidades de ensino, ao tipo de certificação, que por sua vez remonta à instituição formadora (se universidade, faculdade, pública ou privada), à democratização do ensino, entre outras temáticas.

A segunda categoria, a carreira docente, nos remete a pensar de que sujeito falamos. Leva-nos, portanto, a outras subcategorias: a identidade social docente, à representação da e do profissional na sociedade, remuneração, políticas públicas de escolarização, precarização do trabalho docente, entre outras.

A terceira categoria, a ocupação, passa pelas práticas pedagógicas, pelos saberes docentes e considera o docente e a docente como socializadores do conhecimento. É na ocupação que podemos pensar quais domínios esse sujeito precisa para socializar o conhecimento, ou seja, que capacidades serão necessárias para esse profissional contemporâneo?

A quarta categoria de análise do trabalho docente está voltada para o estudo do docente enquanto sujeito que pensa, sente, sofre e angustia-se com e na profissão. Discute o mal-estar docente, sendo este definido por Esteve (1999) como "[...] efeitos permanentes de caráter negativo que afetam a personalidade do professor como resultado das condições psicológicas e sociais em que se exerce a docência". (p. 25).

$\mathrm{Na}$ tentativa de analisar o trabalho docente da professora de Educação Infantil fizemos um recorte e este texto discutirá duas, das quatro categorias apontadas: a formação profissional e a ocupação profissional. Isso não significa ignorar as demais ou não considerá-las fundamentais para a análise do trabalho docente; apenas não serão enfatizadas neste texto.

Neste estudo, essas categorias foram discutidas e analisadas a partir de dados sobre a formação e a ocupação das professoras de Educação Infantil, levantados no Município de Vilhena/RO, em outubro e novembro de 2007. Os dados coletados nos mostraram que havia sete (07) escolas que trabalhavam com Educação Infantil na zona urbana do Município de 
Vilhena, mas nem todas atendiam exclusivamente crianças de zero a seis anos. Havia também 80 (oitenta) professoras lotadas nessa etapa. Das 80 (oitenta) professoras, 25 (vinte e cinco) professoras devolveram os instrumentais de coleta de dados respondidos, o que representa um universo de $31 \%$ do total de professoras lotadas na etapa.

\section{A formação profissional da professora de educação infantil}

No Brasil, a partir da década de noventa, e principalmente, com a promulgação da Lei de Diretrizes e Bases da Educação Nacional $n^{\circ}$ 9394, de 20 de dezembro de 1996, desencadeou-se uma reforma na educação produzindo alterações na concepção de formação de professores. Considerando que a década da educação se encerraria em dezembro de 2007, procuramos saber como estava a formação das professoras de Educação Infantil do Município de Vilhena.

No levantamento que fizemos junto a todas as escolas de Educação Infantil, das 80 docentes, 79 eram do sexo feminino e apenas um (01) do sexo masculino. Também destas 80 professoras, 01 tem apenas o ensino fundamental, 09 o ensino médio, 45 nível superior completo e 25 cursando nível superior.

Se considerarmos o que propõe a LDBEN n 9394/96, o município não responde legalmente pela Educação Infantil no quesito formação docente. Mas, mais interessante é observar as características que marcam o percurso de formação das 25 (vinte e cinco) professoras que responderam ao instrumental que levantava dados sobre essa questão. Desse número de professoras, 12 (doze) já fizeram o ensino superior e 13 (treze) estavam cursando.

Das 12 professoras que já cursaram nível superior, nove estudaram em instituição pública e três em instituição privada. Outro dado importante é que dessas 12 professoras, 11 estavam, naquele ano, cursando ou já cursaram uma especialização latu sensu, porém apenas uma na área de educação infantil. As demais, todas na área de gestão, supervisão e orientação escolar. Ressaltamos ainda que todas pagaram por sua especialização e não receberam nenhum incentivo financeiro da prefeitura para tal.

Já das 13 (treze) que estavam cursando nível superior, somente 04 estudavam em instituição pública e 07 estudavam em instituição privada. Duas professoras não responderam a essa questão. Seis estudavam em cursos regulares e seis em cursos à distância. Também nesse item uma professora não respondeu.

Os dados também nos revelam que as professoras que já cursaram o nível superior estão na faixa de 6 a 27 anos de profissão, o que nos possibilita inferir que o município há anos não vem contribuindo com a formação de seus quadros, pois das sete professoras que estudavam em instituições privadas, nenhuma delas recebia auxílio financeiro. Outras três que estudam na universidade pública também não recebiam nenhum tipo de auxílio, o que nos mostra que o Artigo 87, das Disposições Transitórias, não “colou”, pois concluímos a Década da Educação e "[...] somente serão admitidos professores habilitados em nível superior ou formados por treinamento em serviço", e as professoras pagam por suas formações com seus parcos salários, mas foram contratadas somente com o magistério, em tempos de Artigo 87 da LDBEN n 9394/96.

Observamos ainda que todas as 25 professoras que responderam aos instrumentais ingressaram no serviço público municipal por concurso público. As professoras que ainda não 
concluíram o nível superior estão na faixa de um (01) a seis (06) anos na educação, o que implicaria em responsabilidade para o município com a formação das mesmas (Formação em serviço), mas não é o que os dados nos revelam.

\section{A ocupação profissional de professoras da educação infantil: saberes e práticas}

Dubar (1992; 1994 apud TARDIF; RAYMOND, 2000, p. 209) afirma que "trabalhar não é exclusivamente transformar um objeto ou situação em uma outra coisa, é também transformar a si mesmo em e pelo trabalho". Nesse sentido o trabalho modifica também a identidade de quem o produz. Trabalhando o ser humano, além de fazer alguma coisa, faz também alguma coisa de si mesmo, consigo mesmo.

De acordo com Tardif e Raymond (2000), os últimos anos do século passado ou, mais precisamente, a partir dos anos de 1980 , os pesquisadores norte-americanos produziram vários estudos sobre a formação docente, divulgados em suas literaturas, que vêm tratando dos saberes que servem de suporte para a tarefa de ensinar, sendo estes saberes entendidos e organizados em duas categorias:

a) Sentido restrito:

[...] designa os saberes mobilizados pelos "professores eficientes" durante a ação em sala de aula (por exemplo, nas atividades de gestão da classe e de gestão da matéria), saberes esses que foram validados pela pesquisa e que deveriam ser incorporados aos programas de formação de professores. (p. 212).

b) Sentido amplo:

[...] designa o conjunto dos saberes que fundamentam o ato de ensinar no ambiente escolar. Esses saberes provêm de fontes diversas (formação inicial e contínua dos professores, currículo e socialização escolar, conhecimento das disciplinas a serem ensinadas, experiências na profissão, cultura pessoal e profissional, aprendizagem com os pares, etc.). (p. 212).

Para este autor, é a esse segundo significado que está ligada a sua própria concepção de saberes docentes. Conforme Tardif e Raymond (2000, p. 210), a experiência profissional e pessoal e a aprendizagem com os pares devem ser consideradas para a construção dos saberes docentes, pois uma pessoa que ensina durante vários anos tem sua identidade confundida com ou carrega algo de sua atividade. Muito de sua existência é caracterizada por sua atuação profissional. Portanto, tornamo-nos professores e professoras a partir de nossa atuação e do que a ela incorporamos.

Tornar-se professor ou professora está relacionado ao tempo. Tempo de trabalho e de aprendizagem, pois "[...] se o trabalho modifica o trabalhador e sua identidade, modifica também, sempre com o passar do tempo, o seu saber trabalhar". (TARDIF; RAYMOND, 2000, p. 210). Por essa lógica não seria possível acreditar que há um tempo de aprendizagem e um tempo do trabalho. Como vimos, no caso do magistério, a aprendizagem passa por um período de escolarização, mas esta deve ser articulada com uma formação prática, o que contraria uma racionalidade técnica do saber que supõe uma "[...] resolução instrumental de problemas baseada na aplicação de teorias e técnicas científicas construídas em outros campos [...]", como a pesquisa em laboratórios, por exemplo.

$\mathrm{Na}$ visão de Tardif e Raymond (2000), ao contrário do que propõe a racionalidade técnica, as situações cotidianas e/ou práticas exigem que as/os trabalhadores, neste caso 
as/os docentes, desenvolvam ao longo do trabalho saberes gerados do próprio processo de trabalho e nele fundamentados. Concordamos com o autor quando afirma que justamente esses saberes exigem tempo, prática, experiência, hábito, entre outros.

É importante não negligenciar "[...] as dimensões temporais do saber profissional, ou seja, sua inscrição na história de vida do professor e sua construção ao longo de uma carreira" (TARDIF; RAYMOND, 2000, p. 216).

Observamos, portanto, que tais autores concordam que todo e qualquer sistema de educação para ser modificado, transformado e melhorado precisa estar sintonizado com a formação dos profissionais que atuam na educação. Também consideram a formação docente extremamente necessária para a efetivação das mudanças na educação em geral, apontando a escola como lócus da formação continuada e base da formação inicial (TAMBORIL, 2005).

Porém, ser espaço privilegiado para a sustentação da formação inicial não significa que a escola seja a única fonte formativa a fundamentar a formação inicial, sustentando uma concepção pragmática de educação. Da mesma forma, não significa organizar acadêmicos e acadêmicas dos cursos de graduação para irem à escola, olhá-la e pouco ou nada enxergar (ou, talvez, ver somente o que ela não tem), e voltar para a Universidade falando do que falta à escola. É preciso, sim, evitar rupturas, bloqueios, visões puramente fenomênicas dos processos educativos, que não buscam a realidade concreta. A formação pedagógica para o magistério vai além da pura teoria ou prática pura. Não há a possibilidade de só uma ou outra. Os estudos sobre a vida cotidiana nos ajudam a pensar sobre isso (HELLER, 1972).

Não nos esqueçamos que, no dizer de Charlot (2005, p. 91), "ser professor é defrontarse incessantemente com a necessidade de decidir imediatamente no dia-a-dia da sala de aula. Uma coisa está acontecendo na sala de aula e o professor tem que decidir sem ter tempo suficiente para refletir". Assim, o que nos resta? Confirmar isso e dizer: "nada podemos fazer se o dia-a-dia da escola é assim?" Busquemos outros caminhos.

Tanto a idéia de Charlot, sobre a urgência dos processos pedagógicos, como o conceito de Heller sobre cotidianidade nos ajudam a pensar que a relação teoria e prática é fundamental para os processos formativos. Daí que, quanto maior o acesso ao fazer docente e sua relação com a teoria, maior a possibilidade de acertos, de não agir na cotidianidade pura, de trabalhar com uma práxis mais acertada. Construir a autonomia docente parece ser um caminho, mas de que autonomia se fala quando o assunto é ocupação profissional?

Nestes últimos anos tem ganhado terreno, principalmente nos discursos oficiais, envolvendo as políticas educacionais e as teorias, a idéia bastante pertinente no que diz respeito à formação docente: a idéia de autonomia profissional. Nesse sentido merece ressalva o que diz Contreras (2002), chamando a atenção para as concepções que têm sustentado tais discursos, pois segundo ele tais concepções mostram-se "[...] insuficientes, quando não claramente equivocadas, para poder formular o problema da autonomia dos professores" (p. 90). A autonomia não pode ser considerada unicamente como "[...] status ou atributo". Ou seja, "como autoridade unilateral do especialista [...]" (p.192), conforme propõe a concepção que vê o profissional como um especialista técnico; nem unicamente como "[...] responsabilidade moral individual [...]" (p.192), proposta fundada na concepção que pensa o profissional como profissional reflexivo, e; nem apenas como "[...] emancipação: liberação profissional e social das opressões" (p.192), de acordo com a concepção de profissional como intelectual crítico. Não que as duas últimas concepções não sejam fundamentais, mas porque isoladas apresentam limitações. 
Tardif (2003) aborda a questão da autonomia no âmbito da subjetividade. Para ele é preciso reconhecer que

[...] os professores de profissão possuem saberes específicos que são mobilizados, utilizados e produzidos por eles no âmbito de suas tarefas cotidianas. [...] o que se propõe é considerar os professores como sujeitos que possuem, utilizam e produzem saberes específicos ao seu ofício, ao seu trabalho (p. 228).

A autonomia, no contexto da prática de ensino, deve ser compreendida como um processo de construção permanente. Nessa perspectiva, está relacionada com as pessoas com as quais se trabalha. Representa, conforme Contreras (2002), "[...] uma busca e um aprendizado contínuos, uma abertura à compreensão e à reconstrução contínua da própria identidade profissional, ou de sua maneira de realizá-la em cada caso" (p.199).

No entender de Contreras (2002), a autonomia se desenvolve em um espaço de relações, não no isolamento. A autonomia profissional não significa o isolamento dos demais colegas, nem oposição à intervenção social na educação e nem ao princípio fundamental da responsabilidade pública. A autonomia significa exercício, construção e encargo prático com uma tarefa moral, da qual é responsável publicamente.

É preciso entender a genealogia dos saberes docentes, pois,

De fato, as experiências formadoras vividas na família e na escola ocorrem antes mesmo que a pessoa tenha desenvolvido um aparelho cognitivo aprimorado para nomear a qualificar o que a retém dessas experiências. Além de marcadores afetivos globais conservados sob a forma de preferências de tempo e de lugares para indexar e fixar essas experiências na memória (TARDIF; RAYMOND, 2000, p. 216).

Isso significa, de acordo com esses autores, que "os vestígios da socialização primária e da socialização escolar do professor ficam, portanto, fortemente marcados por referenciais do tempo e de lugares para indexar a fixar essas experiências na memória". (TARDIF, 2000, p. 216).

A estrutura temporal da consciência proporciona a historicidade que define a situação de uma pessoa em sua vida cotidiana como um todo e lhe permite atribuir, muita vezes a posteriori, um significado e uma direção à sua própria trajetória de vida (TARDIF; RAYMOND, 2000, p. 216).

Nesta perspectiva, pensar a autonomia docente é ter clareza de que os docentes produzem conhecimentos e podem produzir estratégias para ação. Evidentemente que esse processo leva em conta as características institucionais nas quais se desenvolve seu trabalho e a forma pela qual o contexto condiciona suas próprias maneiras de ver as coisas.

$\mathrm{Na}$ coleta de dados que fizemos sobre as razões de as professoras estarem no magistério da Educação Infantil, ressaltamos que das 25 (vinte e cinco) que devolveram os questionários respondidos, 24 (vinte e quatro) dizem atuar na Educação Infantil porque de fato gostam muito dessa etapa.

As professoras também informaram sobre seus ingressos na profissão. É interessante observar que a maioria fez opção, escolheu a profissão. Isso nos faz refletir sobre muitas análises superficiais que nos dão a entender que a profissão docente é profissão para quem não tinha outra coisa para fazer. A profissão docente é profissão escolhida. Escolhemos ser professores e professoras, não estamos nela por acaso.

Quanto aos saberes necessários para a docência na Educação Infantil, fizemos um recorte a partir das falas das próprias professoras. Suas idéias foram organizadas em quatro 
temáticas englobando um campo de conhecimento que, na opinião das professoras, deve constituir conhecimento para aquela que pretende atuar na etapa da Educação Infantil, sendo: a) atitudinais - relativo a valores, compreensão, paciência e amor; b) conceituais - sobre os conteúdos a serem socializados; c) teóricos - sobre os processos psicológicos de desenvolvimento (em seus vários aspectos) e aprendizagem; d) procedimentais/didáticos relacionados ao como fazer.

Sem desconsiderar a abrangência deste estudo, apenas voltado para o trabalho docente na Educação Infantil, e os limites da coleta de dados, fizemos algumas inferências sobre o que pensam as professoras em ralação aos conteúdos a serem socializados na Educação Infantil.

As professoras, de modo geral, enfatizam muito um conteúdo que não está escrito nos livros e que geralmente não se aprende pela leitura e pela fala: são os conteúdos atitudinais. Esse conteúdo aparece explicitamente: amor, carinho, paciência. Sabermos que não são suficientes, mas são componentes importantes para se lidar com seres (quaisquer que sejam) em processo de desenvolvimento. Porém somos levadas a pensar que talvez o sentimento de maternidade esteja presente e as professoras ainda carreguem a marca do magistério de quase um século: amor, carinho e paciência.

Interessante observar que os conhecimentos acerca dos conteúdos a serem socializados, ligados às diversas áreas (geográfico, histórico, biológicos, artísticos, matemáticos, lingüísticos, entre outros) não foram enfatizados pelas professoras, que são os conteúdos conceituais. Poucas professoras fizeram referências a alguns deles. Fica-nos a pergunta: será que as professoras não os consideram importantes para a socialização nessa etapa?

No entanto, as professoras apresentam outros saberes importantes, a nosso ver, fundamentais para a professora dessa etapa (e não só desta etapa): são os conhecimentos sobre os processos de desenvolvimento. Sabemos que conhecer os processos de desenvolvimento humano é fundamental, mas se este conhecimento não estiver conectado com os outros conteúdos e a didática, de nada adianta, visto que a transposição didática não acontecerá. Ou seja, as professoras saberão falar sobre os processos, mas não planejarão boas situações de aprendizagem a partir desses conhecimentos.

Para Tardif e Reymond (2000, p. 216), o saber deve ser entendido como, [...] "saber" um sentido amplo que engloba os conhecimentos, as competências, as habilidades (ou aptidões) e as atitudes dos docentes, ou seja, aquilo que foi muitas vezes chamado de saber, de saber-fazer e de saber-ser. (p. 212).

Vimos que as professoras destacam alguns conhecimentos didáticos como importantes para o trabalho na Educação Infantil, e uma delas destaca a experiência como fundamental. As pesquisas realizadas por Tardif e Reymond (2000), apontam que os saberes que são os sustentáculos para o ensino, da maneira como são vistos pelos professores e professoras,

[...] não se limitam a conteúdos bem circunscritos que dependeriam de um conhecimento especializado. Eles abrangem uma grande diversidade de objetos, de questões, de problemas que estão todos relacionados com seu trabalho. Não correspondem, ou pelo menos muito pouco, aos conhecimentos teóricos obtidos na universidade e produzidos pela pesquisa na área de educação: para os professores de profissão, a experiência de trabalho parece ser a fonte privilegiada de seu saberensinar (p. 213). 
O estudo nos possibilita inferir que a ênfase ainda está nos saberes produzidos pela universidade, mas não se restringem a eles. É possível que isso se deva à separação que a academia geralmente faz entre teoria e prática, formando professoras puramente teóricas que, na experiência, transformam-se em puramente práticas. No entanto defendemos que, quanto mais a formação inicial estiver atrelada à prática das escolas, do contexto real, muito maior será a possibilidade de formação de um profissional e de uma profissional capaz de construir sua autonomia, um profissional e uma profissional com condições de saber entrar e sair na cotidianidade, passível à discussão com outras pessoas, com a teoria e com as realidades vividas nas e pelas escolas.

Analisando o que nos informaram as professoras, e confirmando o que nos diz Tardif e Raymond (2000), os saberes apontados por elas como importantes e que o autor denomina de sentido amplo, provavelmente provém

[...] de fontes diversas (formação inicial e contínua dos professores, currículo e socialização escolar, conhecimento das disciplinas a serem ensinadas, experiências na profissão, cultura pessoal e profissional, aprendizagem com os pares, etc.) (p. 212).

Isso nos ajuda a inferir que é fundamental, para a formação inicial, melhorar a educação superior no sentido de aproximá-la das escolas, para que as teorias e as experiências possam ser compartilhadas, confrontadas, melhoradas. Isso no caso da formação de futuros docentes, pois para quem já está atuando, a parceria com as universidades e a formação de grupos de estudos nos parece fundamental. O necessário é a inter-relação entre estes saberes construídos por ambas para que não se tornem excludentes. A universidade não pode ser, e não deve ser, vista como espaço apenas da produção teórica, assim como a escola não pode ser olhada como aquele espaço que apenas aplica conhecimentos produzidos pelas agências de pesquisa.

\section{Algumas considerações}

Percebemos, a partir dos dados coletados, que há um distanciamento do poder público para com a formação de professores e professoras e que também ainda há uma visão da educação infantil como uma extensão da casa, onde a professora deve ser meio "parente" das crianças. Isso nos preocupa, pois o magistério, em qualquer série, mas em nosso caso, da Educação Infantil, exige mais que paciência, amor, compreensão, gostar de crianças, ser bem humorada e criativa. É preciso sim, além dos saberes voltados para o desenvolvimento infantil, os saberes da didática e dos conteúdos das áreas específicas a serem trabalhados em cada série bem como uma boa compreensão, por parte da professora, do mundo sócio-cultural em que vivemos, com todas as suas riquezas e mazelas. Um mundo de explorados e exploradores, em um estado de desumanidade acelerado, em que alguns seres humanos "são crianças por muitos anos" e outros "desconhecem o que consideramos como fundamentais para o ser criança". É papel da Universidade trabalhar a formação docente para este mundo atual, com toda a sua complexidade.

Assim, assumindo seu compromisso com a educação a Universidade tem um papel inconfundível na formação dos/das profissionais que atuarão na Educação Infantil, visto que os/as mesmos precisam dar conta das demandas colocadas pela sociedade atual - capitalista, excludente, impregnada pelos conceitos da modernidade - no sentido de garantir a todas as 
pessoas, desde a mais tenra idade, direitos já conquistados, sendo um deles, o acesso aos saberes produzidos pela humanidade.

Resta lembrar que a Universidade não representa o único espaço de formação, mas lugar pensado para tal, e por isso, não poderá se eximir da responsabilidade de formar bem aqueles e aquelas que atuarão na educação de crianças, adolescentes e adultos, pois estes, muitas vezes, contam apenas com a escola para a realização de um sonho por uma vida melhor.

Sem nos distanciarmos da convicção de que a formação inicial é apenas o começo de uma longa caminhada a ser complementada pela formação continuada - desenvolvida pelas escolas e/ou pelas Universidades, ou ainda, que poderá ser em parceria (ou não) coma as Universidades - elegemos uma formação profissional em que a teoria e prática sejam momentos indissociáveis na formação da professora e do professor da Educação Infantil para que o trabalho docente tenha sentido e seja menos doloroso para o professor e professora e para as crianças.

\section{Referências}

BRASIL. Congresso Nacional. Lei de Diretrizes e Bases da Educação Nacional n 9394 de 20 de dezembro de 1996.

CHARLOT, Bernard. Formação de professores: a pesquisa e a política educacional. In: PIMENTA, Selma Garrido; GHEDIN, Evandro (Org.). Professor reflexivo no Brasil: gênese e crítica de um conceito. 3. ed. São Paulo: Cortez, 2005.

CODO, Wanderley (Org.). Educação: carinho e trabalho. São Paulo: Vozes, 1999.

CONTRERAS, José. A autonomia de professores. Trad. Sandra Trabucco Valenzuela. São Paulo: Cortez, 2002.

ESTEVE, José Manuel. El estrés de los profesores: propuestas de intervención par su control. Educación u derechos humanos. Montevideo, n. ${ }^{\circ}$ 12, 1991.

O mal-estar docente: a sala-de-aula e a saúde dos professores. Trad. Durley de Carvalho Cavicchia. Bauru, SP: EDUSC, 1999.

FREITAS, Helena Costa Lopes de. Formação de professores no Brasil: 10 anos de embate entre projetos de formação. In: Educação e Sociedade, Campinas, vol. 23, n. 80, setembro/2002, p. 136-167. Disponível em http://www.cedes.unicamp.br.

HELLER, Agnes. 0 cotidiano e a história. Trad. Carlos Nelson Coutinho e Leandro Konder. Rio de Janeiro: Paz e Terra S.A, 1972.

OLIVEIRA, Dalila Andrade. A reestruturação do trabalho docente: precarização e flexibilização. In: Educação e Sociedade, Campinas, SP, vol. 25, n. 89, p. 1127-1144, Set./Dez, 2004. Disponível em http://www.cedes.unicamp.br.

TAMBORIL, Maria Ivonete Barbosa. Políticas públicas para a formação docente: um estudo em Porto Velho-RO. 2005. 220 f. Tese. (Doutorado em Psicologia). Instituto de Psicologia, Universidade de São Paulo, São Paulo, 2005.

TARDIF, Maurice; RAYMOND, Danielle. Saberes, tempo e aprendizagem do trabalho no magistério. In: Educação e Sociedade, ano XXI, n 73, Dezembro de 2000.

TARDIF, Maurice. Saberes docentes e formação profissional. 3. ed. Petrópolis: Vozes, 2003. 


\section{CULTURA E CURRÍCULO: PERCURSOS INDISSOCIÁVEIS NO PROCESSO DE FORMAÇÃO CONTINUADA DA PROFESSORA DOS ANOS INICIAIS}

\section{Maria Cândida Müller}

Freire (1996), no livro Pedagogia da Autonomia, apontou que "ensinar, exige pesquisa" e destacou que o conhecimento novo produzido supera outro que antes foi novo e que será ultrapassado por outro no futuro.

Assim, seguindo esta idéia de Freire, tão importante quanto conhecer o conhecimento existente e validado pela ciência moderna é estar aberto e apto à produção de conhecimentos que ainda não existem ou que são desconsiderados por essa mesma ciência, como os saberes da experiência feita, de que tanto nos alertou o autor.

E nesta perspectiva, buscar a transformação possível para uma escola mais dinâmica e viva, pautada na diversidade dos seus integrantes e nas culturas que compõem este espaço, na busca da superação de situações alienadoras e pasteurizadoras do cotidiano escolar, onde aparentemente só o conhecimento aceito como científico é estudado.

$\mathrm{Na}$ sala de aula, nós professoras temos como objeto de nosso fazer pedagógico o chamado "conhecimento sistematizado e acumulado pela sociedade", que foi produzido ao longo da história da humanidade, marcada pela história dos vencedores. No entanto, nossos estudantes trazem consigo outros tipos de conhecimentos, vivências e culturas que não necessariamente estão contemplados no chamado currículo formal da escola.

Knijnik (2004), pesquisadora na área de Etnomatemática, aponta em um de seus trabalhos que a escola tem praticado a política do conhecimento dominante, uma política que compartimentaliza, que engaveta o conhecimento do mundo, fazendo-nos pensar ser "natural" que a escola esteja organizada em disciplinas, que o tempo e espaço escolar sejam distribuídos em aulas de Matemática, Língua Portuguesa, História, Geografia, hora do recreio.

Esta compartimentalização, de tempo, espaço e conteúdo ocorre mesmo nos anos iniciais, onde apesar de uma única professora ser responsável pelo desenvolvimento das atividades pedagógicas, esta divisão também persiste.

Desta forma, considera-se natural que a escola seja assim, não nos é permitido pensar em uma estrutura diferente da que temos hoje neste espaço que não seja a divisão de disciplinas, a distribuição de horários, do espaço onde ocorrem as atividades, as diferentes séries e níveis de ensino.

Nesta perspectiva, determinados conteúdos, saberes construídos ao longo da história da humanidade e que não fazem parte da cultura dominante também ficam interditados ao espaço escolar. É quase impossível se pensar num currículo escolar que contemple outros conhecimentos que não os usuais "acumulados ao longo da história da humanidade".

Moreira e Candau (2003) relatam que nos inúmeros momentos de trabalho com docentes da educação básica, em diferentes cidades do país, encontram perguntas que 
evidenciam a dificuldade dos professores e professoras em tornar a cultura como eixo central do processo curricular e mais ainda como conferir uma orientação multicultural às suas práticas.

No entanto, estes mesmos autores apontam que há significativas experiências desenvolvidas que procuram "transcender o pluralismo benigno de visões correntes de multiculturalismo e afirmar as vozes e os pontos de vista de minorias étnicas e raciais marginalizadas de homens e mulheres das camadas populares". (MOREIRA; CANDAU, 2003, p.156).

Porém, apesar da existência destas experiências, os autores observam que não se pode considerar que uma "orientação multicultural emancipatória costume nortear as práticas curriculares das escolas e esteja presente, de modo significativo, nos cursos que formam docentes que nelas ensinam" (op. cit. p.157).

Nesta perspectiva, este texto apresenta a discussão de algumas idéias sobre currículo e sua relação com propostas de formação continuada de professores dos anos iniciais para o ensino de matemática.

\section{Cultura, currículo, matemática e formação do professor}

As relações entre escola e cultura são inerentes ao processo educativo, mas é preciso sempre se questionar qual a cultura que permeia o processo educacional, ou seja, ao se seguir os programas curriculares, qual cultura estamos privilegiando.

Nesse sentido, Paulo Freire alertou para a relevância da cultura dos esquecidos, das classes populares nos processos educativos, apontou para a importância de se considerar seus modos de dar sentido a suas vidas cotidianas, o que inclui como utilizar o conhecimento veiculado na escola para lidar com o seu mundo.

Padilha (2008) defende o diálogo crítico como alternativo às construções monoculturais em educação. $E$ o currículo é uma destas construções que se não se transformar em algo vivo e dinâmico que reconhece, respeita e valoriza as diferenças e semelhanças culturais, tenderá a homogeneizá-las.

A perspectiva educacional defendida por Padilha (2008, p. 2) nos remete "à discussão das conexões entre os vários conhecimentos e saberes humanos e suas manifestações socioculturais, socioambientais, relacionais e produtivas, visando a uma educação que promova realmente a inclusão social [...]".

A educação escolar beberá segundo este autor, na fonte das várias concepções curriculares, educacionais e políticas, mas não negará aqueles conhecimentos que foram deixados de lado ao longo da história da ciência moderna por não terem as características do chamado conhecimento científico.

A dicotomia entre teoria e prática que está arraigada na nossa formação profissional, apresenta uma visão fragmentada para a ciência, a educação, para a concepção de currículo e com certeza dificulta um olhar diferente sobre o espaço escolar, enfatizando a segmentação do mesmo.

Por exemplo, as dificuldades encontradas para o desenvolvimento de projetos interdisciplinares têm, de acordo com Padilha (2008), suas raízes nesta oposição teoria e prática. 
Nesta perspectiva o ensino de matemática é exemplar. Os estudantes passam pela educação básica e superior sem entender o sentido dos conceitos trabalhados pela matemática, possivelmente por esta cisão teoria e prática.

A chamada matemática escolar, que num processo de ressignificação nada mais é do que a matemática acadêmica com suas marcas eurocêntricas é um dos maiores exemplos da cultura dominante que permeia os currículos escolares.

A matemática estudada na escola é uma matemática histórica, isto é, pertence ao passado e está diretamente relacionada ao desenvolvimento da civilização ocidental. $\mathrm{Na}$ educação básica, os conteúdos matemáticos escolares são aqueles que foram produzidos especialmente no período Antiguidade (egípcios, babilônios) e sistematizados pelos gregos (Elementos de Euclides) e chegam ao máximo no que foi produzido até a revolução industrial.

É importante ressaltar que esta matemática histórica quando foi desenvolvida tinha a motivação do contexto em que estava sendo criada, no entanto ao ensiná-la nas escolas de hoje, este contexto não mais existe, o momento histórico é outro, os determinantes socioculturais também. Daí o grande desafio do educador e da educadora: ensinar aos alunos e alunas um conhecimento que perdeu o seu contexto de criação, mas que apesar disto continua sendo importante para a nossa sociedade.

D’Ambrosio (1996) afirma que do ponto de vista de motivação contextualizada, a matemática que se ensina nas escolas hoje é morta, poderia ser tratada como um fato histórico (p.31).

No entanto, esta matemática é ferramenta para um mundo altamente tecnologizado e o professor e a professora estão, como afirma Knijinik (2004), "inevitavelmente comprometidos em possibilitar, em favorecer, em facilitar o acesso aos saberes matemáticos hegemônicos que operam a sociedade contemporânea" (p.2).

Neste contexto, a educação para a cidadania e consequentemente a incorporação desta perspectiva ao ensino de matemática torna-se fundamental. Uma reconceituação de currículo como uma estratégia para a ação educativa defendida por D’Ambrosio pode ser um dos caminhos para a incorporação desta discussão no espaço escolar.

A passagem de um currículo estruturado, cartesiano, anterior à prática educativa por um currículo dinâmico que reflete o momento sociocultural e a prática educativa nele inserida é fundamental para uma mudança no enfoque dado ao ensino de matemática hoje. D'Ambrosio (1996) afirma que "o currículo dinâmico reconhece que nas sociedades modernas as classes são heterogêneas, reconhecendo-se entre os alunos interesses variados e uma enorme gama de conhecimentos prévios" (p.89).

Ainda, segundo este autor, o currículo visto como estratégia de ação educativa leva à troca de informações, conhecimentos e habilidades entre professor/alunos, por meio de uma socialização de esforços em direção a uma tarefa comum. Cada um contribui com o que sabe com o que tem, com o que pode, levando seu empenho ao máximo na concretização de um objetivo comum.

Desta forma, a matemática que se estuda na escola também pode estar relacionada ao momento em que vivemos, e não ser apenas mais um tópico na seqüência de conteúdos que devem ser desenvolvidos.

Ao se discutir currículo tem-se necessariamente que discutir os conteúdos e as práticas de ensino destes conteúdos. $E$ assim, volta-se para a discussão sobre a dicotomia entre teoria e prática que está arraigada na nossa formação profissional. 
De acordo com Padilha (2008, p.5), "quando dicotizamos teoria e prática estamos diante de uma concepção fragmentada de ciência e currículo, que opera com lógicas excludentes". Esta visão fragmentada que hierarquiza as ciências, as culturas e saberes, impossibilita uma concepção de currículo que contemple e trabalhe com a diversidade e as diferenças de uma forma natural, numa lógica de integração e não de exclusão.

A busca de alternativas que privilegiem a união dialética entre teoria e prática propicia a construção de um currículo em ação (GERALDI, 2008), onde a seleção de bibliografia, os registros e sistematizações das experiências, a escolha de materiais didático-pedagógicos possibilitará um processo educacional carregado de sentido para os alunos e alunas.

Neste sentido, a formação permanente do professor possibilita a reflexão do professor sobre sua prática, analisando as contradições encontradas no dia-a-dia, capacitando-o para esta análise e uma possível mudança a partir desta reflexão, criando condições para que construa seu currículo em ação de acordo com Geraldi (2008).

Ripper (1996), ao discutir as dificuldades da formação do professor no contexto do uso das tecnologias, aponta para a necessidade de redefinição do papel do professor para que este também desenvolva uma visão social da sua função enquanto professor.

Isto implica que o professor deve compreender sua prática como uma prática social, sendo ele um ator vital deste processo (KRAMER, 1989). Além disso, esta autora aponta que "... os mecanismos de formação do professor (no caso, em serviço) devem ser percebidos como prática social inevitavelmente coerente com a prática que se pretende implantar na sala de aula entre professores e alunos" (KRAMER, 1989).

Braga (1996) apresenta os caminhos propostos para a formação continuada do professor discutida por Kramer:

[...] Kramer sugere algumas maneiras de como a formação em serviço pode favorecer a
melhoria da qualidade de ensino: pensando a prática, buscando novos conhecimentos,
transformando essa prática; favorecendo o acesso e a análise dos conhecimentos em
jogo; abrindo espaço para o pedagógico, superando a alienação e o afastamento dos
profissionais da escola em relação ao ensino; fortalecendo as escolas, redefinindo o
papel dos especialistas (de supervisor para desafiador ou coordenador das
discussões); oferecendo elementos de análise crítica sobre o papel do professor;
propiciando a construção do Projeto Pedagógico da escola (BRAGA, 1996, p. 66).

Retomando a idéia de Freire (1996) com relação à formação de professores, quando aponta que o conhecimento novo produzido supera outro que antes foi novo e que será ultrapassado por outro no futuro, refletindo com isso que "ensinar exige pesquisa" e consequentemente ser professor significa ser um pesquisador.

Assim, tão importante quanto conhecer o conhecimento existente sobre como se ensinar, como trabalhar os conteúdos escolares, como construir um currículo, é estar aberto e apto à produção de conhecimentos que ainda não existem, é participar de experiências de formação que permitam ao professor repensar sua prática através da pesquisa. Como Freire afirmou, ensinar, aprender e pesquisar lidam com estes aspectos do ciclo do conhecimento (conhecer e estar aberto e apto à produção de conhecimentos). 


\section{GETEMAT: uma proposta de formação continuada para o ensino de matemática ${ }^{27}$}

O Grupo de Pesquisa - GEP (Grupo de Estudos Pedagógicos) - dentre os diversos projetos na linha de pesquisa de Formação e Condição Docente, desenvolve o Projeto de Pesquisa GETEMAT.

O GETEMAT - Grupo de Estudo e Trabalho Pedagógico de Ensino de Matemática tem como principal objetivo desenvolver uma proposta de formação continuada para professoras ${ }^{28}$ dos anos iniciais tendo como eixo de discussão o ensino da matemática.

A proposta de formação continuada em serviço O GETEMAT tem por objetivo a melhoria do trabalho pedagógico dos professores dos anos iniciais que atuam na rede pública de Vilhena $(\mathrm{RO})$ e se desenvolve através de dois eixos.

O primeiro eixo é constituído por cursos de formação específicos para aprimoramento do conhecimento matemático relacionado aos conteúdos dos anos iniciais do Ensino Fundamental. O segundo, e principal, contempla como já foi a apresentado a formação de grupos de estudo para discussão de aspectos teóricos relevantes à prática em sala de aula, estudando os diversos conteúdos de Matemática sob a ótica do ensino dos mesmos nos anos iniciais do Ensino Fundamental.

Esta proposta está baseada em experiências já realizadas na área de formação de professores, que privilegiam o acompanhamento do professor durante sua capacitação, e a efetiva integração dos estudos realizados ao seu cotidiano de trabalho. Especialmente, nos trabalhos de formação continuada em serviços desenvolvidos pelo Grupo de Pesquisa LEIA (Laboratório de Educação e Informática Aplicada) da Faculdade de Educação da UNICAMP, que privilegiam a criação de espaços de estudo e pesquisa nas escolas onde os professores buscam alternativas de formação.

Nesta perspectiva o fortalecimento do grupo de professores na escola em que desenvolvem um projeto inovador, efetivamente cria a possibilidade de formação de uma comunidade científica educacional de discussão e consequentemente uma melhoria do trabalho docente.

Pretende-se com o desenvolvimento do GETEMAT possibilitar às professoras dos anos iniciais condições para construírem o chamado currículo em ação. Mais ainda, utilizando a categoria do inédito - viável proposta por Freire (1981) procura-se, ao trabalhar na perspectiva de formação proposta pelo GETEMAT, transcender uma concepção de trabalho pedagógico desprovido de sentido tanto para o educador quanto para o educando.

De acordo com Freitas (2005), a categoria do inédito-viável está relacionada à compreensão da história como possibilidade, da qual decorre uma posição utópica que se opõe à visão fatalista da realidade. Ainda de acordo com esta autora, esta categoria.

[...] relaciona-se ao entendimento de que a realidade não é, mas está sendo e, portanto, pode ser transformada. Tal perspectiva é própria da consciência crítica que compreende a historicidade construindo-se a partir do enfrentamento das situaçõeslimites que se apresentam na vida social e pessoal (FREITAS, 2005, p.6).

Sendo assim, o inédito-viável é "uma proposta prática de superação, pelo menos em parte, dos aspectos opressores percebidos no processo de conhecimento que toma como

\footnotetext{
${ }^{27}$ Projeto financiado pelo CNPq, Edital n55/2008 - CT Amazônia. Processo 575443/2008-1.

${ }^{28}$ Adota-se a terminologia professoras por serem mulheres a grande maioria dos professores que atuam neste período da Educação Básica. 
ponto de partida a análise crítica da realidade" (FREITAS, 2005, p.7). No caso da proposta do GETEMAT, é a busca de superação das dificuldades encontradas pela professora dos anos iniciais para trabalhar com matemática junto aos seus alunos e alunas.

A formação do professor que está em serviço possibilita a reflexão sobre sua prática, analisando as contradições encontradas no dia-a-dia, capacitando-o para esta análise e uma possível mudança a partir desta reflexão.

O GETEMAT é desenvolvido segundo os princípios da pesquisa-ação. Este tipo de pesquisa permite que os sujeitos em estudo possam se desenvolver profissionalmente de "dentro para fora", pois tem como ponto de partida as preocupações e interesses das pessoas envolvidas na sua prática profissional. (ENGEL, 2000, p. 183).

Além disso, de acordo com Thiollent (1996, p. 17), "com a pesquisa-ação, os pesquisadores pretendem desempenhar um papel ativo na própria realidade dos fatos observados". O GETEMAT atua de forma significativa nos espaços escolares, procurando a partir do conhecimento da realidade, propor ações que possam modificar esta realidade.

Thiollent, citado em Pimenta (2005, p.523), afirma que

\begin{abstract}
A pesquisa-ação tem por pressuposto que os sujeitos que nela se envolvem compõem um grupo com objetivos e metas comuns, interessados em um problema que emerge num dado contexto no qual atuam desempenhando papéis diversos: pesquisadores universitários e pesquisadores (professores no caso escolar). Constatado o problema, o papel do pesquisador universitário consiste em ajudar o grupo a problematizá-lo, ou seja, situá-lo em um contexto teórico mais amplo e assim possibilitar a ampliação da consciência dos envolvidos, com vistas a planejar as formas de transformação das ações dos sujeitos e das práticas institucionais.
\end{abstract}

Assim, os grupos de estudo e trabalho pedagógico têm a função de constituir os sujeitos da pesquisa - ação, ou seja, o grupo com objetivos e metas comuns interessados em um problema que emerge do contexto da escola.

Ao realizar-se dentro do contexto escolar e mais precisamente na sala de aula a
pesquisa-ação pode constituir uma estratégia pedagógica, um espaço de
conscientização, análise e crítica [...]. Os professores que vivenciam esta modalidade
de pesquisa têm a possibilidade de refletir sobre as suas próprias práticas, sua
condição de trabalhador, bem como os limites e possibilidades do seu trabalho. [...]
Dessa forma, a práxis pedagógica dos professores envolvidos na pesquisa, partindo da
própria ação docente, refletida, fundamentada teoricamente e sistematizada se constitui
uma modalidade de formação contínua com amplas possibilidades transformadoras e
emancipatórias (PIMENTA, 2005, p. 526).

$\mathrm{Na}$ nota de rodapé do seu texto Pedagogia da Autonomia, Freire (1996, p. 32) apresentou a seguinte idéia:

\begin{abstract}
Fala-se hoje, com insistência, no professor pesquisador. No meu entender o que há de pesquisador no professor não é uma qualidade ou uma forma de ser ou de atuar que se acrescente à de ensinar. Faz parte da natureza da prática docente a indagação, a busca a pesquisa. $O$ de que se precisa é que, em sua formação permanente, 0 professor se perceba e se assuma, porque professor, como pesquisador.
\end{abstract}

De acordo com Freitas (2005), Paulo Freire por conta da sua própria experiência como professor defendeu a constituição de espaços coletivos de formação, a fim de que se neste espaço se desenvolvam práticas de observação, registro, reflexão e discussão permanentes sobre $o$ ato de ensinar.

Neste sentido, observa-se que a proposta de metodologia baseada na pesquisa-ação para o projeto GETEMAT procura evidenciar estas idéias apresentadas por Freire. 


\section{Referências}

BRAGA, A. J. P. Do Mobral ao computador: a implantação de um projeto de informática educativa na educação de jovens e adultos. 1996. Dissertação de Mestrado em Educação, Faculdade de Educação, UNICAMP, Campinas.

D'AMBROSIO. U. Educação Matemática - da teoria à prática. Campinas (SP): Papirus, 1996.

ENGEL, G. I. Pesquisa-ação. Educar, Curitiba, Editora da UFPR, n. 16, p. 181-191. 2000.

FRANCO, M. A. S.. Pedagogia da Pesquisa-Ação. Educação e Pesquisa, São Paulo, v. 31, n. 3, p. 483-502, set./dez. 2005.

FREIRE, P.. Pedagogia do oprimido. São Paulo: Paz e Terra, 1981.

Pedagogia da autonomia. São Paulo: Paz e Terra, 1996.

FREITAS, A. L. S. Pedagogia do inédito-viável: contribuições de Paulo Freire para fortalecer o potencial emancipatório das relações ensinar-aprender-pesquisar. V Colóquio Internacional Paulo Freire - Recife, 19 a 22 de setembro, 2005.

GERALDI, C. M. G. Produzindo inéditos viáveis na escola pública. Mimeo, 2008.

KNIJNIK, G. O que os movimentos sociais têm a dizer à Educação Matemática? In: VII ENCONTRO NACIONAL DE EDUCAÇÃO MATEMÁTICA, 2004, Recife. Anais do VII Encontro Nacional de Educação Matemática. Recife: Universidade Federal de Pernambuco, 2004. Disponível em: http://www.sbem.com.br/files/viii/pdf/15/PA06.pdf. Acesso em: 01 out. 2009.

KRAMER, S. Melhoria da qualidade do ensino: o desafio da formação de professores em serviço. Revista Brasileira de Estudos Pedagógicos, Brasília, v. 70, n. 165, p. 189-207, ago., 1989.

MOREIRA, A. F. B.; CANDAU, V. M. Educação escolar e cultura(s): construindo caminhos.

Revista Brasileira de Educação, n. 23, Maio/Jun/Jul/Ago 2003, p. 156-68. Disponível em:

http://www.scielo.br/pdf/rbedu/n23/n23a11.pdf. Acesso em: 01 out. 2009.

PADILHA, P. R. Educar em todos os cantos: por uma educação intertranscultural. In: I SEMINÁRIO DE EDUCAÇÃO, 2008, Vilhena-RO. Anais do I SED. Vilhena: Departamento de Pedagogia - UNIR/Campus de Vilhena, Vilhena, 2008. 1 CD-ROM.

PIMENTA, S. G. Pesquisa-ação crítico-colaborativa: construindo seu significado a partir de experiências com a formação docente. Educação e Pesquisa, São Paulo, v. 31, n. 3, p. 521539, set./dez. 2005.

RIPPER, A. V. O preparo do professor para as novas tecnologias. In: OLIVEIRA, V. B. de (Org.). Psicopedagogia e Informática, São Paulo, SENAC, 1996, p. 55-84.

THIOLLENT, M. Metodologia da Pesquisa-ação. São Paulo: Cortez, 1996. 


\section{PROGRAMA DE FORMAÇÃO DE PROFESSORES ALFABETIZADORES:RESULTADOS DE UMA EXPERIÊNCIA DE FORMAÇÃO CONTINUADA}

\section{Edna Maria Cordeiro}

Ao longo da história da educação, poucas foram as oportunidades dadas aos professores para que se manifestassem sobre suas práticas pedagógicas, no entanto, são freqüentemente responsabilizados pela má qualidade do ensino. Várias ações institucionais vêm sendo introduzidas no universo escolar: propostas curriculares, planos educacionais, sistemas de avaliação etc. Os professores não têm opinado a respeito, como se fossem profissionais incapazes de manifestarem-se sobre o que os afeta diretamente.

$\mathrm{Na}$ atualidade há uma consciência de que a formação continuada de professores é um desafio relacionado com a reflexão sobre a prática docente. Em virtude desta modificação, as políticas de formação do profissional da educação básica - a exemplo do PROFA - defendem uma formação centrada numa construção coletiva, a favor da concepção reflexiva do educador, em contraposição ao caráter tecnicista e conteudista, e a favor da valorização da profissão docente.

A formação continuada de professores constitui-se fator imprescindível para uma educação que atenda as reais necessidades da comunidade educativa. Nessa perspectiva da necessidade de formação permanente para a ação pedagógica, Paulo Freire $(1996$, p. 32) afirma a importância da pesquisa para o desenvolvimento do fazer docente:

Não há ensino sem pesquisa e pesquisa sem ensino. Enquanto ensino continuo buscando, reprocurando. Ensino porque busco, porque indaguei, porque indago. Pesquiso para constatar, constatando, intervenho, intervindo educo e me educo. Pesquiso para conhecer o que ainda não conheço e comunicar ou anunciar a novidade.

Dada a importância da prática pedagógica desenvolvida a partir da pesquisa e ação permanentes, as políticas públicas de formação continuada de professores precisam permitir aos docentes, melhoria das competências pedagógicas, no âmbito da teoria e da prática, com ênfase na reflexão crítica do fazer docente.

O Programa de Formação de Professores Alfabetizadores - PROFA, destinado aos professores que ensinam a ler e escrever no Ensino Fundamental foi implantado como uma alternativa de formação continuada que pretendia contribuir para uma mudança de abordagem pedagógica, no que se refere à didática da alfabetização e a metodologia de formação de professores. Propunha uma abordagem educativa construtivista, a partir da problematização e elaboração de hipóteses de aprendizagem, caracterizando uma prática docente reflexiva. Tal desafio lançado pelo programa em questão instigou o desejo de investigar as contribuições do PROFA para o desenvolvimento de uma prática docente reflexiva e crítica. 
Assim, define-se o pressuposto central desta investigação entendendo que as políticas públicas de formação de professores, devem assumir papel de destaque como estratégia de desenvolvimento de competências voltadas para uma prática docente reflexiva e crítica. Então buscou-se investigar as contribuições do PROFA para o desenvolvimento da prática docente e analisar em que medida os objetivos do PROFA foram alcançados.

É necessário atentar para uma das mais importantes características da formação profissional docente, o fato desta formação constituir-se num processo de reflexão durante e sobre as experiências vivenciadas ao longo da vida pessoal e profissional; e não um amontoado de cursos e seminários. Para Nóvoa (1997) é preciso considerar as experiências do tempo de aluno - tanto na educação básica, como no curso de graduação - quando se construíram algumas representações e modelos de prática profissional, inicialmente seguindo exemplos, com o passar do tempo, por meio de modelos próprios de atuação docente.

Sabendo da relação existente entre as políticas públicas de formação de professores e a atuação docente, foram investigadas as seguintes questões: O PROFA contribuiu para o desenvolvimento de uma atuação docente reflexiva e crítica? Em que medida os objetivos do PROFA foram alcançados?

A pesquisa de campo foi realizada durante o ano de 2006 em Porto Velho, onde existem setenta escolas públicas estaduais, divididas em nove pólos. O levantamento de dados desta investigação foi realizado em um grupo de formação em serviço - PROFA, do Pólo VI, composto por vinte e nove professores de escolas da rede pública estadual de ensino.

Para este estudo foi realizada uma investigação de abordagem qualitativa, devido às características das questões e objetivos que norteiam a pesquisa, bem como em virtude da complexidade da realidade investigada. Estruturou-se a partir da coleta de dados, realizada através de entrevistas parcialmente estruturadas com seis professoras participantes do PROFA. Tal amostragem foi definida voluntariamente, quando em reunião com o grupo em formação, 6 professoras manifestaram a intenção de fazer parte da investigação como entrevistadas. A quantidade da amostra também justifica-se em função do instrumental de coleta de dados - entrevista - pois uma quantidade maior inviabilizaria a adequada análise dos dados.

Além do estudo de caso, tornou-se necessária a realização da pesquisa bibliográfica e documental. A bibliográfica justificou-se pela necessidade de relacionar os conhecimentos teóricos com a pesquisa de campo; já a pesquisa documental encontrou sua relevância no fato de que para realizar a análise da atuação do PROFA, toma-se por base os objetivos e a metodologia do referido programa, expressos no manual de apresentação.

A pesquisa bibliográfica e documental somam-se aos dados levantados através das entrevistas. Optou-se pela entrevista parcialmente estruturada, composta por uma série de questões, apresentados verbalmente em uma ordem prevista, mas na qual o entrevistador pode acrescentar perguntas de esclarecimento. Segundo Laville e Dionne (1999, p. 188-189), na entrevista parcialmente estruturada, os dados que se pretendem levantar são expressos em "temas particularizados".

Os dados coletados pelas entrevistas foram estruturados de forma a possibilitar a transcrição integral das falas. Após a transcrição foi realizada a validação junto às entrevistadas, para então proceder a uma leitura preliminar com vistas ao conhecimento do todo e, em seguida as opiniões das professoras foram analisadas a partir de "enunciados" representativos, caracterizando a análise de conteúdo. 
Após a interpretação dos objetivos do PROFA e análise da transcrição das entrevistas conjunto de depoimentos relativos a cada questão, destacando as falas mais relevantes para a pesquisa, realizou-se a análise comparativa entre os resultados alcançados pela implementação da Formação Continuada de Professores em Rondônia e os resultados esperados pelo programa.

Para a análise dos dados buscou-se referência na perspectiva da formação continuada do professor reflexivo, bem como em sua prática reflexiva e crítica, mais especificamente na prática pedagógica reflexiva e crítica é defendida por Freire (2002, p.68), quando afirma que "ninguém educa ninguém, ninguém educa a si mesmo, os homens se educam entre si, mediatizados pelo mundo". Portanto faz-se necessário o pensar e refletir constante na prática e sobre a prática, para compreensão das formas de apropriação da aprendizagem, das relações sociais, seus interesses e possibilidades.

Também não se pode excluir do referencial analítico a visão de Nóvoa (1997), que por sua vez, propõe a formação continuada de professores fundamentada nas tendências interativo-construtivistas, estruturadas a partir dos contextos e da dialética a elas inerente. Sendo assim priorizam a atitude investigativa, a crítica e a reflexão.

Para a apresentação da análise comparativa dos resultados alcançados pela implementação da formação continuada de professores e os resultados esperados pelo programa, foram selecionadas citações representativas da atuação dos objetivos do PROFA. Também foram consideradas as orientações do programa e o referencial teórico pertinente.

Os programas de formação continuada em serviço, a exemplo do PROFA precisam promover a independência intelectual dos professores para que não fiquem a espera do repasse de técnicas, que imaginam resolver as dificuldades relativas às práticas pedagógicas. Nesse sentido é preciso gerar um desequilíbrio nas concepções e práticas pedagógicas incorporadas pelos docentes, ao invés de técnicas, dinâmicas e informações, garantir momentos de aprendizagens nos quais os professores construam um processo ativo de investigação teórico-prática dos problemas educativos de suas salas de aula para, então, avançar no conhecimento de teoria e da prática educativa.

A formação do professor passa por um processo de crescimento pessoal e aperfeiçoamento profissional, além da transformação da cultura escolar, que inclui a implementação e consolidação de novas práticas participativas e de gestão democrática. Conforme Nóvoa (1999), a formação do professor crítico reflexivo implica três tipos de desenvolvimento: pessoal, profissional e organizacional.

Para análise e discussão da problemática proposta, o quadro teórico foi organizado e delineado pelo cenário do objeto investigado. Iniciou-se pela construção do balizamento teórico do professor reflexivo. Em seguida desenhou-se o contexto histórico e as concepções da formação de professores, com o objetivo de situá-lo na contemporaneidade.

No desenvolvimento desta investigação buscou-se a compreensão e análise reflexiva sobre as contribuições das políticas públicas de formação de professores para uma atuação docente reflexiva e crítica. Também buscou-se referência na atuação docente dos professores em formação, no contexto político-educacional específico da escola pública, compreendendo dessa forma o perfil dos docentes em formação através dos programas de formação, neste caso no PROFA.

O desafio de promover o domínio da leitura e da escrita de todos os alunos é um dos desafios primordiais a serem enfrentados pelos sistemas de ensino, uma vez que os domínios 
da leitura e da escrita são essenciais não só ao desenvolvimento da escolaridade, como também ao exercício da cidadania.

O PROFA foi implantado em Rondônia na rede estadual de ensino no período de 2001 a 2002, em parceria com o Ministério da Educação (MEC), e em 2004 por iniciativa da Secretaria Estadual de Rondônia (SEDUC-RO) com recursos próprios desta secretaria. A implantação do programa a nível nacional e estadual se deu em virtude dos baixos índices de aprovação na $1^{\text {a }}$ série, período em que as crianças são alfabetizadas.

O programa em questão é um curso de formação em serviço com 180 horas, no qual $75 \%$ do tempo é dedicado a estudos em grupo e $25 \%$ para estudos individuais realizados pelo professor, com leituras e atividades de escrita. Há materiais impressos, com apresentação do programa, guia de orientações metodológicas e coletânea de textos; além de vídeos com 30 programas aglutinados em três módulos: Processo de aprendizagem, Propostas didáticas 1 e 2.

Os módulos são compostos de unidades equivalentes a um ou mais encontros, ocorridos uma vez por semana no horário destinado ao planejamento. Em Rondônia os professores das séries iniciais do Ensino Fundamental possuem contratos de trabalho de 40 horas semanais, distribuídas 20 horas para o exercício da docência e 20 horas para o planejamento das aulas.

No PROFA três atividades são permanentes, ou seja, ocorrem em todos os encontros: Leitura Compartilhada de textos literários, realizada pelo professor formador; Rede de Idéias, momento em que os professores compartilham suas idéias, dão opiniões, manifestam dúvidas, a partir das tarefas propostas; e os trabalhos pessoais, que envolve situações de leitura e/ou escrita a serem realizadas fora do grupo, com o objetivo de complementar o que foi tratado no encontro.

Embora o público-alvo do programa seja formado pelos professores que alfabetizam, ele está aberto a outros profissionais da Educação que pretendam aprofundar seus conhecimentos sobre o ensino e a aprendizagem no período da alfabetização.

Os resultados referentes ao grupo do qual fizeram parte as professoras entrevistadas, apontam para o desenvolvimento de reflexões e ações voltadas para o respeito aos saberes do educando, para a formação continuada centrada na escola e a permanência de estudos em grupo como possibilidade de melhoria da prática pedagógica, conforme exemplificado em alguns depoimentos abaixo:

\footnotetext{
Assim, é, eu acho que respeitar o que o aluno sabe [...] nunca pensar ou achar que ele não sabe de nada, respeitar o que ele já tem, e a partir daí começar o trabalho, e também a questão da criança produzir [...] Ela ser também instrumento da sua aprendizagem [...] (PROFESSORA 6).

A própria escola participar da elaboração do programa [...] oportunidade pra levar um das escolas onde será aplicado, pra ser elaborado. Apesar de ter vindo um material bem elaborado [...] se fosse com gente da escola, sairia um pouco melhor (PROFESSORA 2).

[...] aqui é outra realidade [...] eles deviam ver isso (PROFESSORA 3).

Os professores precisam fazer grupos de estudo pra melhorar o trabalho em sala de aula (PROFESSORA 4).
}

Dentre os principais avanços percebidos estão: a apropriação, pela maioria das professoras, de novos conhecimentos, reforçando outros que dominavam, a construção de novas competências; marcando assim a passagem de um estado menor para um domínio maior de conhecimento, refletindo sobre suas aprendizagens e compreensão dos conteúdos 
abordados, num processo de auto - regulagem, tomando decisões coerentes e autônomas frente ao trabalho de alfabetização. Avanços compreendidos a partir das falas a seguir:

[...] já sabia alguma coisa, eu fiz vários cursos, aí eu queria saber mais [...] (PROFESSORA 5).

[...] tudo que envolve o processo de alfabetização eu procuro participar, pra aprender mais, pra ver as novidades e ver o que tá mudando (PROFESSORA 6).

[...] ensine ao aluno coisas que venha a servir [...] o aluno tem que ser crítico e saber se virar na vida lá fora, fora do mundo da escola [...] tá sempre inovando com os conteúdos (PROFESSORA 2).

[...] eu aprendi que só há aprendizagem quando há reflexão sobre a mesma [...] isso daí ficou bem claro pra mim [...] a questão de você aprender a refletir mais, a questionar mais, sempre buscando a aprendizagem do aluno [...] (PROFESSORA 4).

Através da análise dos relatos transcritos, constata-se que o investimento na formação continuada, viabilizado pelo PROFA - numa perspectiva reflexiva, avança para uma construção individual e coletiva da prática pedagógica. No entanto ao relacionar os avanços ocorridos com os esperados pelo programa, é perceptível um descompasso entre o proposto e o alcançado. O programa de formação pretendia atingir os seguintes objetivos:

Ampliar o universo de conhecimento dos professores cursistas sobre a alfabetização e a reflexão sobre a prática profissional.

Subsidiar o trabalho do professor, em termos teóricos, metodológicos e organizacionais, oferecendo-lhe uma dimensão coletiva e institucional.

Garantir ao professor o direito de aprender a ensinar - através da Formação Contínua - para assegurar ao aluno o direito à aprendizagem (BRASIL, 2001, p. 11).

Com base nos relatos das entrevistas notou-se que "ampliar o universo de conhecimento sobre a alfabetização e a reflexão sobre a prática" foi o objetivo melhor desenvolvido no decorrer do processo de formação continuada, uma vez que a metodologia do PROFA viabiliza o acesso ao conhecimento teórico referente ao processo de alfabetização numa perspectiva construtivista, além de possibilitar um movimento de reflexão sobre a ação.

O segundo objetivo do PROFA, "subsidiar o trabalho do professor, em termos teóricos, metodológicos e organizacionais, oferecendo-lhe uma dimensão coletiva e institucional", não poderia ter sido totalmente alcançado, pois a dimensão institucional só poderia ser contemplada com uma formação continuada elaborada a partir de pesquisa das reais necessidades da instituição escolar. Portanto faz-se necessário estabelecer como princípio básico - a reflexão conjunta e comprometida dos atores desse processo educativo sobre suas próprias práticas.

Há um objetivo que apresenta controvérsia em sua própria formulação: "Garantir ao professor o direito de aprender a ensinar - através da Formação Continuada - para assegurar ao aluno o direito à aprendizagem" (ibidem), pois se o programa privilegia um processo de alfabetização construtivista, portanto dialógico, ao professor cabe o desenvolvimento de práticas pedagógicas problematizadoras, nas quais o aluno deve ser sujeito de sua própria aprendizagem. Sendo assim, para que o professor deve desenvolver a competência de "aprender a ensinar?" Não seria mais apropriado desenvolver-se para mediar a construção dos conhecimentos de seus alunos e dele próprio, numa perspectiva dialógica?

Tais compreensões são motivos expressivos para repensar a organização da formação continuada, pois embora tenham ocorrido consideráveis avanços, privilegiados pela metodologia do PROFA, o fato dele não ter sido elaborado a partir das necessidades da escola, não permitiu um real envolvimento institucional. Espera-se que a formação continuada em serviço garanta espaços institucionalmente planejados para a construção e reconstrução 
de saberes. Nesta perspectiva o professor assume o lugar de profissional da docência em formação e por sua vez passa a ter maiores possibilidades para estabelecer relações entre a realidade da sala de aula e as teorias, como também passa a desenvolver uma atitude mais reflexiva e ativa diante de sua prática pedagógica.

A formação continuada só se torna construtora de conhecimentos quando é permanente, pois a passagem de uma prática docente centrada na transmissão do conhecimento para outra baseada na sua construção, não nasce de um dia para o outro. Segundo Freire (2001, p.97), "será a análise crítica de nossa problemática, a ser feita e refeita constantemente, que irá dando a escola o que precisamos".

A prática não pode ser vista como algo que vem de fora, mas como algo embutido na teoria a partir da reflexão permanente. É possível defender, pela pesquisa levada a efeito, que os profissionais de educação devem assumir a necessidade de recriar a formação continuada em serviço, promovendo-a como a diretriz proposta por Imbernón (2001) que valoriza a descoberta, a construção de conhecimentos, a fundamentação teórica, a reflexão e a construção de teorias, tendo como referência a prática pedagógica.

A formação continuada precisa levar o professor a uma prática reflexiva, buscando incorporar dados necessários a uma atividade dinâmica, refletindo o mundo em que vivemos que se renova e se relaciona a cada instante. Segundo Freire (2001, p. 40):

\footnotetext{
Nas relações que o homem estabelece com o mundo há, por isso mesmo, uma pluralidade na própria singularidade. $\mathrm{E}$ há também uma nota presente de criticidade. $\mathrm{A}$ captação que faz dos dados objetivos de sua realidade, com os laços que prendem um dado a outro, ou um fato a outro, é naturalmente crítica, por isso, reflexiva, e não reflexa, como seria na esfera dos contatos (FREIRE, 2001, p. 40).
}

O professor, em sua prática, deve procurar o entendimento das relações que se processam no interior do contexto escolar e identificar de que maneira essa trama interfere nos resultados de sua prática profissional.

Ressalta-se, ainda, que a prática pedagógica deve ser pautada pelo desafio de conceber a escola como um ambiente educativo, no qual trabalhar e formar-se não sejam atividades distintas, mas correlatas.

O professor, em sua prática, deve procurar o entendimento das relações que se processam no interior do contexto escolar e identificar de que maneira essa trama interfere nos resultados de sua prática profissional. Nesse processo ocorre a reelaboração constante dos saberes da docência, que compreende os saberes iniciais, os da experiência e os pedagógicos, os quais se confrontam entre si, no cotidiano das práticas, num processo coletivo de troca de experiências e práticas, para constituir novos saberes resultantes da prática docente. Para Pimenta (2003, p. 21) nesse contexto, a formação contínua "ganhou força [...] uma vez que aí explicitam as demandas da prática, as necessidades dos professores para fazerem frente aos conflitos e dilemas de sua atividade de ensinar".

Conforme Schön (2000, p. 41), esforços na criação e negociação democrática de ações voltadas à formação, numa perspectiva prático-reflexiva, encaminham os professores à compreensão da importância de "aprender a ver o processo de aprendizagem como o trabalho prático [...] de mudança, de reconstrução contínua, sem fim", portanto faz-se necessário romper o círculo vicioso teoria versus prática estabelecido na formação docente. 
Ressalta-se, ainda, que a prática pedagógica deve ser pautada pelo desafio de conceber a escola como um ambiente educativo, no qual trabalhar e formar-se não sejam atividades distintas, mas correlatas.

Observa-se que, no campo da formação contínua de professores, têm sido realizadas experiências sobre a importância da prática pedagógica, valendo-se do resultado da própria experiência para, a partir da vivência, criar novas relações pedagógicas, visto que os relatos dos professores servem de referência à compreensão do processo de formação e do trabalho que se desenvolve em sala de aula. Nessa perspectiva, a formação do professor deve ir além da transmissão de conhecimentos ou atualização docente, pois a finalidade primordial da formação do professor é o desenvolvimento da capacidade refletir sobre a própria prática docente, com a intenção de compreender e refletir sobre a realidade social e o exercício da docência.

Os programas de formação contínua em serviço, a exemplo do PROFA precisam promover a independência intelectual dos professores para que não fiquem a espera do repasse de técnicas, que imaginam resolver as dificuldades relativas às práticas pedagógicas. Nesse sentido é preciso gerar um desequilíbrio nas concepções e práticas pedagógicas incorporadas pelos docentes, ao invés de técnicas, dinâmicas e informações, garantir momentos de aprendizagens nos quais os professores construam um processo ativo de investigação teórico-prática dos problemas educativos de suas salas de aula para, então, avançar no conhecimento de teoria e da prática educativa.

Segundo Freire, em sua obra Pedagogia da Indignação (1997, p. 114) para haver mudança na prática educativa, se faz necessária a permanência dos estudos - em virtude do "inacabamento" do ser humano. Do ponto de vista coerentemente progressista a melhoria na qualidade da educação implica a formação permanente dos educadores. Para Freire (2003), a formação permanente se funda na prática de analisar a prática. É pensando sua prática, naturalmente com a presença de pessoal altamente qualificado, que é possível perceber embutida na prática uma teoria não percebida ainda, pouco percebida ou já percebida, mas pouco assumida.

A melhoria na qualidade dos cursos de formação contínua constitui-se um dos pilares para a valorização docente, pois é preciso investir no professor, no profissional responsável pela iniciativa do diálogo crítico com os alunos e envolver o professor no contexto atual de mudanças por que passa o cenário educacional, fazendo-o perceber-se como um dos principais atores desse processo. Concomitantemente, se faz necessário repensar as condições de trabalho, as propostas salariais, o plano de carreira, o clima de trabalho e outros temas afins.

A pesquisa realizada demonstra que as propostas de formação continuada precisam considerar o processo de teorização pré-existente em cada docente, permitindo assim que ela possa traduzir suas expectativas e sugestões - elaboradas durante os encontros de formação - em estratégias metodológicas propiciadoras de aprendizagens para todos os seus alunos.

Reafirma-se, portanto a necessidade da implementação de políticas públicas de formação permanente, destinadas a assegurar 0 desenvolvimento profissional dos professores, numa perspectiva reflexiva e crítica. No entanto, por conta da descontinuidade dos programas de formação docente, os espaços de reflexão na ação e sobre a ação são limitados. É preciso tornar a escola um espaço privilegiado de discussão e combate à exclusão social, tendo os professores como agentes desta transformação. 
Embora os objetivos do PROFA não tenham sido totalmente alcançados, os dados demonstram que o público alvo apresenta disposição e interesse em aprender e incorporar à docência os princípios de uma concepção reflexiva no fazer docente, mesmo que essa escolha possa mudar a base da estrutura sob a qual sentem segurança para sua prática pedagógica. Portanto, a melhoria na qualidade da educação implica na formação permanente dos educadores - fundamentada na prática de refletir a ação pedagógica, pois é pensando sua prática, com o auxílio dos formadores que se torna possível ao professor a teoria inserida na prática, para então assumi-la, como possibilidade de superar a instabilidade entre a teoria e prática docente.

O PROFA gerou desequilíbrios nas formas de pensar e agir dos pesquisados, principalmente no tocante a práticas "bancárias" e "construtivistas", mas para que esse desequilíbrio possa se encaminhar para uma real mudança na prática docente, o processo de construção de conhecimento profissional do professor precisa ser contínuo.

Torna-se fundamental que a formação continuada seja parte do projeto pedagógico das escolas para que os professores, ao definirem o que farão num determinado período letivo, também estabeleçam o que precisarão estudar para a efetivação daquele projeto pedagógico. Nesta perspectiva, é condição primordial a organização de espaços nos quais os docentes possam refletir sobre suas práticas desenvolvidas no cotidiano escolar e construam alternativas de superação dos problemas.

É também imprescindível a ocorrência da reflexão sobre a prática como elemento constitutivo das políticas de formação, principalmente porque essa leitura crítica desvelará espaços de tensão a serem trabalhados. Porém, a reflexão, ao tempo em que contribui para a superação de limites e construção de possibilidades, deve fundamentar-se em sólidas bases teóricas e epistemológicas - sempre tendo por princípio o processo democrático na formação de professores.

\section{Referências}

BARDIN, Laurence. Análise de Conteúdo. Trad. Luís Antero Reto; Augusto Pinheiro. Lisboa: Edições 70, 1995.

BRASIL. Programa de Formação de Professores (PROFA): Documento de apresentação. Brasília: Ministério da Educação - Secretaria de Educação Fundamental, 2001.

FREIRE, Paulo. Pedagogia da Autonomia - saberes necessários à prática educativa. Rio de Janeiro: Paz e Terra, 1996.

UNESP, 1997.

Pedagogia da Indignação: cartas pedagógicas e outros escritos. São Paulo:

FREIRE, Paulo. Educação e atualidade brasileira. 2. ed. São Paulo: Cortez, 2001.

Política e educação. 7. ed. São Paulo: Cortez, 2003. (Coleção Questões da Nossa

Época; v. 23)

IMBERNÓN, Francisco. Formação docente e profissional: Formar-se para a mudança e a incerteza. São Paulo: Cortez, 2001.

LAVILLE, Christian.; DIONNE, Jean. A construção do saber: Manual de metodologia da pesquisa em ciências humanas. Porto Alegre: Artmed, 1999.

NÓVOA, Antonio. (Org.). Profissão Professor. Porto, Portugal: Porto Editora, 1999.

(Coord.). Os professores e sua formação. Porto: Porto Editora, 1997. 
PIMENTA, Selma Garrido. Didática, didáticas específicas e formação de professores: construindo saberes. In: Concepções e práticas em formação de professores - diferentes olhares. Rio de Janeiro: DP\&A. Goiânia, Alternativa, 2003.

SHÖN, Donald. A. Educando o profissional reflexivo: um novo desing para o ensino e a aprendizagem. Trad. Roberto Cataldo Costa. Porto Alegre: Artmed, 2000. 


\title{
UM OLHAR SOBRE O CICLO BÁSICO EM ROLIM DE MOURA - RONDÔNIA
}

\author{
Bianca Santos Chisté \\ Luzenir da Mota Alves
}

\section{Questões primeiras}

Nas últimas décadas a aprendizagem da leitura e da escrita tem sido objeto de discussão acentuada, tanto nas esferas educacionais, quanto político e social, visto que, o fracasso do sistema educacional em alfabetizar as crianças da classe popular torna-se cada vez mais evidente. Procurando caminhos para amenizar a situação alguns estados implantaram na rede, ainda na década de 60 , os ciclos escolares, acreditando ser uma oportunidade de garantir a alfabetização de todas as crianças, já que o tempo para isso, em alguns casos, era considerado curto e comprometedor do processo de aprendizagem.

Entre os autores que discutem sobre a temática no Brasil, alguns enfatizam que o conceito diverge da forma como é empregado em âmbito acadêmico, pedagógico e político (ARROYO, 2002; GROSSI, 2004). Outros, além de reconhecer que as pesquisas nessa área ainda são tímidas, destacam a importância de conhecermos os efeitos negativos que os ensaios inovadores propostos pelos estados acarretaram na qualidade do ensino (PATTO, 2005), bem como de direcionarmos o foco para práticas e processos em ação no cotidiano escolar.

Entre os argumentos daqueles que criticam os ciclos destaca-se a idéia de que o ele foi entendido como um amontoado de séries, e usado como estratégia para aprovar automaticamente os/as estudantes, elevando com isso as estatísticas educacionais, camuflando a democratização do conhecimento. Todavia, estudos revelam que ele representa uma tentativa de superar "a excessiva fragmentação do currículo que decorre do regime seriado durante o processo de escolarização", (BARRETO; MITRULIS, 2001, p. 103), bem como, o rompimento das formas organizativas que privilegiam os processos seletivos.

Esta organização articula outros aspectos que fortalecem a proposta, tais como: concepção de aluno, de educação escolar gratuita e obrigatória, processo avaliativo, acompanhamento paralelo e recuperação, concepção de conhecimento e teoria de aprendizagem fundamentada pela proposta, composição e consideração de turmas heterogêneas dentre outras, enfim, novas formas de se pensar os tempos e os espaços escolares, que afetam os sujeitos envolvidos no processo de escolarização.

Entre os diversos aspectos sob os quais o ciclo pode ser discutido, elegeu-se, para este artigo, uma análise sobre algumas dificuldades que as educadoras, enfrentavam em sua atuação em escolas com esse regime. Para isso ouviram-se, em um contexto de discussão e 
reflexão sobre o andamento do ciclo, as professoras ${ }^{29}$ que atuavam nas séries iniciais do ensino fundamental da rede Estadual de Educação em Rolim de Moura - RO, no ano de 2007. Busca-se, então nesse artigo, refletir sobre a organização do sistema escolar, haja vista que, no ideário da sociedade e da própria comunidade educacional, a modalidade de ensino, por si só, garante o ensino e a aprendizagem das crianças, e não um conjunto de condições externas e internas à escola.

\section{O que dizem os estudos}

A implantação do ciclo no país ocorreu em um período de redemocratização do ensino, quando a seriação, forma de organização adotada na maioria das escolas brasileiras, passou a ser questionada quanto aos seus pressupostos e concepções norteadoras. Assim, educadores preocupados com o aumento do fracasso e da evasão escolar, elaboraram propostas para amenizar e/ou erradicar práticas reprodutoras e concepções cristalizadas. Libâneo (1990, p.60) afirma que

[...] o amadurecimento da consciência crítica por parte de alguns educadores que procuram contestar a pedagogia liberal capitalista e denunciar o caráter reprodutor da escola, iniciou-se na segunda metade da década de 70 , um movimento em torno do papel da educação escolar através da divulgação de obras críticas à educação, estrangeiras e nacionais.

Destacam-se, a partir dos estudos de Barreto e Mitrulis (2001), outros aspectos que impulsionaram o sistema educacional a buscar uma nova maneira de organização das modalidades de ensino:

- A intenção de regularizar o fluxo de alunos ao longo da escolarização, eliminando ou diminuindo a repetência;

- Tentativa de superar a excessiva fragmentação do currículo;

- A ordenação do tempo escolar;

- Universalização das oportunidades de acesso dos alunos à escola;

- Prejuízos que causam à organização e ao financiamento do sistema de ensino;

- As nefastas conseqüências no plano pessoal, familiar e social causadas pela reprovação;

- O desestímulo à aprendizagem causado pela reprovação;

Ao tratar sobre ciclo, Grossi (2002) apregoa que a forma de organização do ensino em ciclo se apóia em opiniões simplistas, que não se sustentam e se contradizem, dentre essas visões a autora destaca:

- A repetência é causada pela avaliação inadequada;

- Denuncia-se a injustiça de um aluno ser reprovado por ponto quando é usado o sistema de notas numéricas;

- Denuncia-se a prova como um instrumento de poder a serviço do autoritarismo do professor. Aprender é um processo, portanto é indevido avaliá-lo por seu produto;

- Que um processo é contínuo e não pode ser subdivididos em séries acoplada a um ano letivo;

${ }^{29}$ Utilizamos o gênero feminino ao abordarmos sobre a pesquisa realizada, devido encontramos somente mulheres atuando no Ciclo Básico de Aprendizagem no ano da investigação. 
- Advogam-se a continuidade do processo de aprender, pela inadmissibilidade de um ou milhares de alunos repetirem séries;

Grossi (2004) acrescenta ainda, que não se assegura a aprendizagem mudando a forma de organizar o ensino, mas sim com uma boa prática para ensinar, o que ocorre paulatinamente e concomitantemente com estudo, reflexão e ação.

Por outro lado, Arroyo (2002) argumenta que o ciclo respeita os tempos de vida e sua especificidade enquanto tempos cognitivos, tempos de formação do sujeito cognitivo, do sujeito ético, do sujeito ativo, do sujeito pra intervenção na sociedade, para intervenção na natureza etc., ou seja, a concepção de ciclos centra-se nos educandos e em seu desenvolvimento. Essa idéia consolida o conceito de educação como formação humana, que lida com seres humanos concretos, sociais e culturais, e não só com mentes que aprendem a ler e escrever, dotados exclusivamente do aspecto cognitivo.

Entretanto, ambos o estudiosos comungam do ideário que a reprovação, a repetência ou qualquer outra forma de exclusão, são práticas escolares medonhas e que precisam ser combatidas, não pela aprovação automática, mas sim pela garantia efetiva da aprendizagem. É imperativo reestruturar a prática por intervenção da reflexão da ação docente, que permita a construção ou reconstrução do conhecimento pelo educando gerando assim uma aprendizagem significativa.

Neste sentido, observamos que há indicativos que nos permitem afirmar que as políticas de ciclos, ao desestabilizarem a proposta tradicional de organização da prática escolar, tendem a estimular professoras a construírem novas referências para o ensino e a aprendizagem a partir de novas afinidades e influências mútuas no cotidiano do espaço escolar, porém, quando as práticas pedagógicas concretas e sua complexidade não são consideradas, quando as educadoras são silenciadas ou não ouvidas pela equipe que concebe as propostas, as mudanças previstas acontecem morosamente, quando não retrocedem. É o que nos revela o próximo tópico da discussão.

\section{Ciclo: desafios e possibilidades}

A organização da escolaridade em ciclos, implantada em Rondônia, em 1998, a partir da Instrução Normativa $n^{\circ}$. 004/1998, caracteriza-se como uma proposta de reorganização curricular com o objetivo de "minimizar os altos índices de evasão e repetência nas séries iniciais do Ensino Fundamental". De acordo com a Instrução Normativa que orientou a implantação do Ciclo no seu Artigo $1^{0}$ :

O Ciclo Básico de aprendizagem se constitui numa estratégia pedagógica e organizacional, oportunizando maior tempo ao aluno para o domínio de processos de leitura, escrita e das operações matemáticas em seus aspectos fundamentais, dando continuidade ao processo educativo, num bloco único, totalizando 02 (dois anos) letivos, aglutinando os objetivos e atividades da $1^{\mathrm{a}}$ e $2^{\mathrm{a}}$ séries do Ensino Fundamental Regular, não havendo retenção do aluno até o final do ciclo (RONDÔNIA, 1998).

O mesmo documento foi reeditado sem alterações nos anos de 1999 e 2001, sob os números 001/GAB/DE/SEDUC/99 (RONDÔNIA, 1999) e 003/GAB/GE/SEDUC/2001 (RONDÔNIA, 2001). Com a mudança de governo, em 2002, a Secretaria de Estado da Educação "implantou" o Projeto Caminhar (RONDÔNIA, 2002), com mesmos objetivos e propostas dos documentos anteriores, desconsiderando que as escolas já trabalhavam com 
essa modalidade organizativa. A implantação do Projeto foi realizada sem a devida avaliação e discussão sobre as potencialidades, as dificuldades e os problemas que a organização acarretava em âmbito escolar. Durante os 10 anos de ciclo em nenhum momento as/os educadoras/es foram ouvidas e/ou consultadas pelos representantes da Secretaria da Educação e sua equipe.

Em 2007, as escolas foram informadas, via ofício circular (№. 0211/07 - GAB/SEDUC), que o Projeto Caminhar, não seria mais desenvolvido pela SEDUC/RO, deixando a cargo das instituições escolares a decisão de continuarem ou não com o então denominado Ciclo Básico de Aprendizagem - CBA. Na cidade de Rolim de Moura, essa situação chegou ao ápice, no início letivo do mesmo ano, diante das inúmeras solicitações e da inquietude das professoras e dos professores em repensar essa forma de organizar o ensino.

Antes da tomada de decisão, promovemos encontros com as/os professoras/es das séries iniciais do ensino fundamental e demais profissionais que atuam nas escolas estaduais, para estudarmos sobre as formas de organizar a educação escolar, o que impulsionou a necessidade dessa organização, e se os problemas enfrentados no ciclo estava, relacionados à forma de disposição do ensino. Os elementos apontaram para alguns aspectos que evidenciaram a singularidade entre as modalidades de organização, bem como, algumas problemáticas em torno desta mesma questão. Em termos gerais, problemas e dificuldades permeiam todos os modelos de dispor o ensino, porém, de acordo com os dados levantados alguns são peculiares a cada um.

Após refletirem sobre as diferentes interfaces que englobam as organizações da escolarização e de analisarem os problemas que enfrentavam no CBA, as educadoras e as demais participantes do encontro elencaram as dificuldades enfrentadas no campo pedagógico e estrutural. O quadro abaixo evidencia algumas das observações realizadas:

\begin{tabular}{|c|c|}
\hline $\begin{array}{l}\text { Dificuldades enfrentadas no âmbito } \\
\text { pedagógico }\end{array}$ & $\begin{array}{llll}\begin{array}{l}\text { Dificuldades enfrentadas } \\
\text { estrutural }\end{array} & \text { no âmbito } \\
\text { estrat } & & \\
\end{array}$ \\
\hline $\begin{array}{l}\text { - Crianças chegam com nível muito } \\
\text { distante para a II etapa; } \\
\text { - Professor sem clareza da proposta de } \\
\text { trabalho com o CBA; } \\
\text { - Falta de clareza quanto aos } \\
\text { conhecimentos que os/as alunos/as terão } \\
\text { que se apropriar até o final da I etapa do } \\
\text { CBA; } \\
\text { - Professores que não tem afinidade com } \\
\text { a alfabetização; } \\
\text { - Coordenadora pedagógica com pouco } \\
\text { conhecimento teórico/prático para ajudar } \\
\text { as/os docentes no fazer pedagógico; } \\
\text { - Falta de parcerias e de coletividade; } \\
\text { - Pouca formação continuada/prática } \\
\text { pedagógica; } \\
\text { - Formação continuada sem linha teórica } \\
\text { definida e condizente com a proposta do } \\
\text { ciclo. }\end{array}$ & $\begin{array}{l}\text { - Salas de aula superlotadas; } \\
\text { - Inclusão de alunos com deficiência em sala } \\
\text { de aula superlotada; } \\
\text { - Falta de material de apoio pedagógico, de } \\
\text { impressão, de computador; } \\
\text { - Carteiras insuficientes para atender à } \\
\text { demanda; } \\
\text { - Rotatividade de alunos. } \\
\text { - Acervo da biblioteca restrito, inadequado e } \\
\text { desatualizado; } \\
\text { - Espaço inadequado para o atendimento } \\
\text { das crianças no horário extra-sala de aula; } \\
\text { - Ausência de profissionais especializados - } \\
\text { psicólogo/a, fonoaudiólogo/a; } \\
\text { - Formação de uma sala de alunos retidos } \\
\text { no ano seguinte ao final do Ciclo. } \\
\text { - Muitas fichas de acompanhamento e de } \\
\text { avaliação; para serem preenchidas pelo/a } \\
\text { educador/a. }\end{array}$ \\
\hline
\end{tabular}


As educadoras apontaram que, com exceção, das crianças que chegam na $2^{\mathrm{a}}$ etapa sem estarem alfabetizadas, as demais situações críticas são encontradas em qualquer modalidade de organizar o ensino. Esse é um dos pontos mais discutidos pelas alfabetizadoras, visto que, a eliminação da reprovação entre as séries acentua a heterogeneidade das crianças de uma mesma turma, forçando-as a trabalharem, ao mesmo tempo, com crianças que estão iniciando a aprendizagem da leitura e da escrita e outras que apresentam uma apropriação considerável dessas competências.

Entretanto, mesmo diante do desafio de trabalhar com classes tão heterogêneas, acreditavam que a eliminação entre as duas séries iniciais, além de diminuir o índice de abandono e retenção, oportuniza maior tempo à criança para a aquisição da leitura e da escrita. Apesar de haver certa supremacia no quantitativo das dificuldades no campo estrutural em oposição ao pedagógico, os pontos listados em relação à prática de ensino revelaram a necessidade de organizar adequadamente os objetivos de ensino; de discutir e promover mudanças na concepção de ensino, de objeto a ser ensinado, de aprendizagem, de avaliação, a partir de uma educação humanista; em assegurar maior tempo dos alunos na escola e pensar nas maneiras de instituir o tempo e o espaço dentro do âmbito escolar. Isto é o que enunciam e anunciam Barreto e Mitrulis (2001, p. 103-104):

\begin{abstract}
A opção por esse regime vem acompanhada, em geral, de outras proposições relativas a aspectos de organização dos sistemas escolares com os quais se apresenta fortemente articulada: concepção de educação escolar obrigatória, desenho curricular, concepção de conhecimento e teoria de aprendizagem que fundamentam o ciclo, processo de avaliação, reforço e recuperação, composição de turmas, enfim, novas formas de ordenação dos tempos e espaços escolares que envolvem os diferentes atores sociais afetados pelos ciclos.
\end{abstract}

Dessa forma, a lógica que permeia cada modalidade organizativa, corrobora que os problemas e dificuldades enfrentadas hoje pelas escolas não estão relacionados simplesmente à modalidade organizativa de ensino, agrega-se principalmente a falta de políticas educacionais adequadas, pois como afirma Kramer, (2003, p. 117), a "prática pedagógica para ser aprimorada necessita de decisão política e ação política". Decisões e ações que se desloquem do discurso oral e do papel e concretizem-se dentro das instituições credenciadas a fomentar e produzir conhecimentos.

O que fazer diante da problemática colocada? Uma das possibilidades primeiras, e talvez a mais fundamental de todas, seja a compreensão da realidade educacional, permitindo com isso conhecer suas potencialidade e limitações, e diante de suas possibilidades saber o que se pode e o que se deve fazer. Portanto, direcionar o olhar na e para dentro da escola permite que o grupo pense nos fatores que interferem negativamente na qualidade do ensino, e em possíveis encaminhamentos com o intuito de amenizar as dificuldades levantadas, não negando a responsabilidade cabível ao Estado.

Se por um lado, é possível afirmar, a partir das discussões realizadas, que a implantação e a consolidação do ciclo possuem determinados aspectos de responsabilidade do Estado - Secretaria de Educação, por outro se admite que compete à comunidade escolar algumas atribuições que tornam o fazer pedagógico mais produtivo e dinâmico. Nesse sentido o próprio grupo problematizou algumas situações dramáticas que estavam vivenciando, apontando possíveis caminhos para superá-las, discutindo quem, como e quando fazer, como exemplificaremos a seguir: 


\begin{tabular}{|c|c|c|}
\hline Problemática & Encaminhamento & Como fazer \\
\hline $\begin{array}{l}\text { - Crianças } \\
\text { que chegam } \\
\text { na } 2^{\mathrm{a}} \text { etapa } \\
\text { não } \\
\text { alfabetizadas }\end{array}$ & $\begin{array}{lr}\text { - Fazer } & \text { parceria } \\
\text { com } & \text { outros } \\
\text { professores } & \text { e } \\
\text { professoras } & \text { e/ou } \\
\text { outros profissionais; } \\
\text { - Desenvolver } \\
\text { projetos; } \\
\text { - Assegurar dentro } \\
\text { da } \\
\text { momentos r escola } \\
\text { estudar. }\end{array}$ & 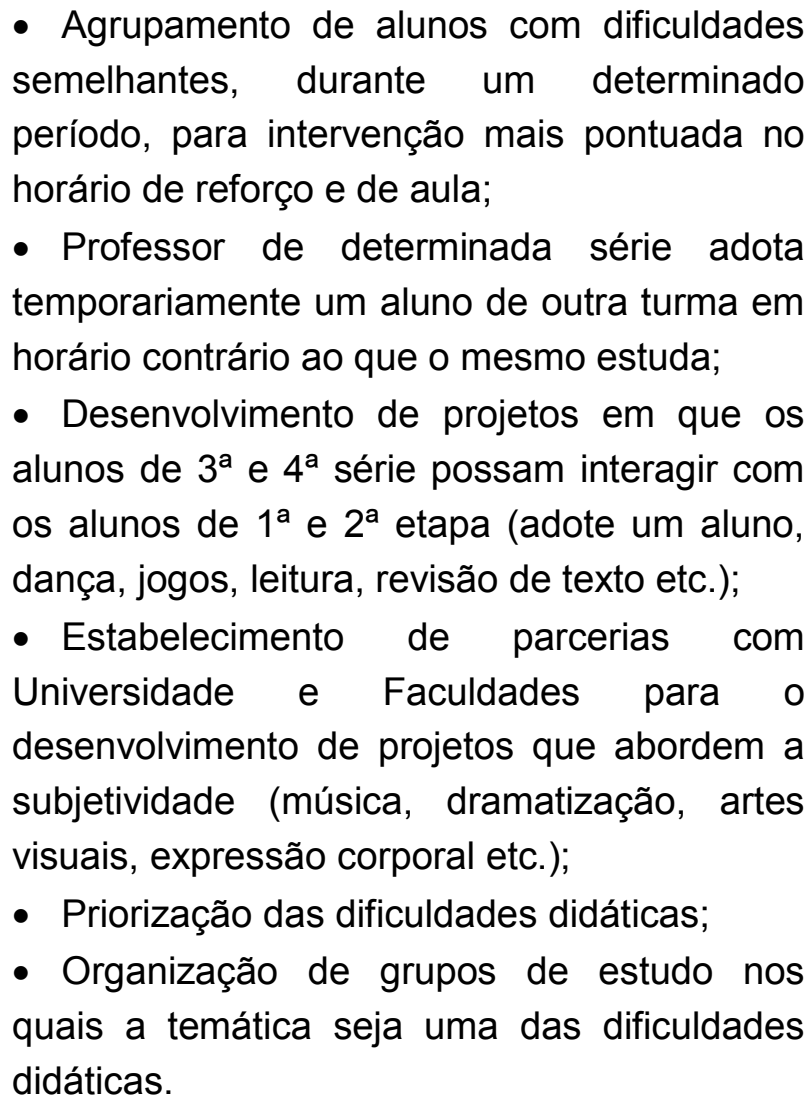 \\
\hline
\end{tabular}

A formação de sala dos "retidos" é outro desafio que a escola ciclada enfrenta. Esses sujeitos acabam sendo marginalizados e estigmatizados por não acompanharem a aprendizagem da turma. Essa conduta, como diz Santos (2002, p. 24), “(...) constitui-se em perversa prática de exclusão, mais cruel ainda que a reprovação, pois obscurece o fenômeno de exclusão escolar e social representada pelo fracasso escolar", com isso perpetua-se a desigualdade social. A solução paliativa encontrada pelas instituições alvo das discussões foi redistribuir os alunos reprovados. Porém, sem um investimento na formação das educadoras e dos educadores, sem acompanhamento e sem um trabalho permanente e duradouro de reflexões, a eficácia das medidas é momentânea.

Sem esquecer que a responsabilidade educacional depende, sobretudo, "de garantir as condições para que as práticas desenvolvidas sejam entendidas como práticas sociais, e seus atores sejam percebidos como sujeitos autores dessas práticas", (KRAMER, 2003, p. 187), ou seja, dos tópicos abordados no primeiro quadro, alguns são de obrigação do Estado, dentre eles destacam-se:

- Aquisição de carteiras adequadas às crianças menores;

- Investimento na formação continuada de todos os profissionais da educação com sólida base teórica e claramente definida;

- Construção de espaço para laboratório de aprendizagem;

- Regulamentação do número máximo de aluno por sala de aula;

- Aquisição de material de apoio pedagógico e tecnológico;

- Contratação de profissionais especializados: psicólogo, fonoaudiólogo; 
- Contratação de educadoras dos demais profissionais de serviços gerais;

- Ampliação e atualização do acervo bibliográfico das escolas;

Todavia, esses e outros problemas, que rondam o sistema educacional, estão longe de ser resolvidos, visto que, a concepção que permeia o "imaginário" da maioria dos nossos governantes e sua equipe, limita-se a pensar que na e para educação basta o aluno, o professor, quadro e giz. Outros ainda acrescentam que, qualquer um pode ser educador, reduzindo-os a condição de peões da escola. De acordo com Patto (2005), a vida das escolas e a dinâmica institucional têm no centro a presença do Estado-patrão,

[‥] um patrão que paga mal, seleciona como pode, não oferece condições materiais, pedagógicas e psicológicas adequadas ao exercício da profissão, desenvolve uma política tecnicista de capacitação docente e avalia a qualidade dos serviços prestados apenas por indicadores numéricos, sempre passíveis de manipulação (PATTO, 2005, p. 23).

Nessa perspectiva é preciso pensar que essa forma de agir favorece tão somente a repetição, a mesmice, a massificação e a manutenção das desigualdades, reforçando práticas cristalizadas. Acrescentamos que como resultado dos estudos e das discussões algumas escolas optaram em voltar à seriação, mesmo enxergando que os problemas apontados independem da modalidade organizativa. Em que isso ajuda, se as dificuldades levantadas muitas se apresentam tanto no ciclo como na seriação?

\section{Conclusões provisórias}

Considerando os estudos e análises feitas, constatamos que a legitimidade dos fundamentos da organização escolar em ciclos é partilhada pelas educadoras, porém tem demonstrado também enigmas na sua consolidação. Sendo assim, acreditamos que seja necessário acréscimo na qualidade da organização da prática na e da escola para não desviar a qualidade de ensino. Sabemos das inúmeras alusões no que diz respeito à diminuição da evasão escolar, defasagem idade/série e retenção.

Os estudos apontam para a necessidade de atuação na formação docente com o objetivo de praticar mudanças no exercício da docência, auxiliando no diálogo entre o ensino e a aprendizagem, bem como, a necessidade de dar voz aos professores no desenvolvimento das políticas, uma vez que são eles os responsáveis pela transformação escolar.

Não basta postular no papel ações, mas sim oferecer condições para que as mesmas sejam desempenhadas com o máximo de qualidade possível. Um exemplo disso, é a garantia do atendimento ao aluno em horário extra-escolar defendida pelo projeto de implantação do Ciclo. Entretanto, todas as escolas públicas do estado de Rondônia vivenciam o dilema de atender seus educandos, ora debaixo de árvores, ora no pátio da escola, ou na quadra poliesportiva, quando não dividem o mesmo espaço físico com mais quatro ou cinco grupos de alunos de diferentes educadores.

A questão central não é a repetência e/ou a evasão, mas sim a não-aprendizagem de um grande contingente de crianças, jovens e adultos. Por isso, questionamos: há uma organização mais adequada para um projeto que tenha como horizonte a plena formação dos educandos e das educandas? Que organização seria essa? Acreditamos que não importa o termo usado, ciclo ou série, a questão é garantir o acesso de todos à educação e assegurar sua permanência por meio de aprendizagens concretas, pois a democratização do ensino, 
como apregoa as novas políticas públicas educacionais, vai além de colocar "toda a criança na escola".

\section{Referências}

ARROYO, M. As séries não estão centradas nem nos educandos nem em seu desenvolvimento. In: BRASIL, Câmara dos Deputados. Solução para as não-aprendizagens: série ou ciclo? Brasília: Coordenação de Publicações, 2002.

BARRETTO, E. S. de S.; MITRULIS, E. Trajetória e desafios dos ciclos escolares no País. Estudos Avançados. São Paulo, vol.15, n. 42, p. 103-140, Maio/Agosto, 2001.

GROSSI, E. P. (Org.). Ciclos: como areia no alicerce. São Paulo: Paz e Terra, 2004.

Por que séries e não ciclos? In: BRASIL, Câmara dos Deputados. Solução para as não-aprendizagens: série ou ciclo? Brasília: Coordenação de Publicações, 2002.

KRAMER, S. Por entre as pedras. Arma e sonho na escola. São Paulo: Ática, 2003.

LIBÂNEO, J. C. Democratização da escola pública. A pedagogia crítico-social dos conteúdos. São Paulo: Loyola, 1990.

PATTO, M. H. S. Exercícios de Indignação: escritos de educação e psicologia. São Paulo: Casa do Psicólogo, 2005.

RONDÔNIA. Instrução Normativa 004 de 10 de fevereiro de 1998. Fixa as diretrizes e normas para operacionalização do ciclo básico de aprendizagem. Governo do Estado de Rondônia. Porto Velho, Secretaria de Estado da Educação, 1988.

RONDÔNIA. Instrução Normativa 001 de 05 de julho de 1999. Fixa normas para operacionalização do ciclo básico de aprendizagem nas unidades escolares da rede pública estadual de ensino. Governo do Estado de Rondônia. Porto Velho. Secretaria de Estado da Educação, 1999.

RONDÔNIA. Instrução Normativa 003 de 17 de setembro de 2001. Fixa normas para operacionalização do projeto caminhar nas unidades escolares da rede pública estadual de ensino. Governo do Estado de Rondônia, Porto Velho: Secretaria de Estado da Educação, 2001.

RONDÔNIA. Projeto caminhar CBA. Governo do Estado de Rondônia. Porto Velho: Secretaria de Estado da Educação, 2002.

SANTOS, A. F. T. A promoção automática é mais perversa ainda do que a reprovação. In: BRASIL, Câmara dos Deputados. Solução para as não-aprendizagens: série ou ciclo? Brasília: Coordenação de Publicações, 2002. 


\section{EDUCAÇÃO COMO DIÁLOGO DE SUJEITOS: AS CULTURAS NO ESPAÇO ESCOLAR ${ }^{30}$}

Flávia Pansini

Há poucos anos o Brasil se inseriu no debate sobre multiculturalismo e interculturalidade o que também suscitou por parte de alguns pesquisadores e pesquisadoras a discussão sobre a cultura no espaço escolar. Como conseqüência dessas discussões, percebemos a escola brasileira e o próprio poder público como um todo realizando um discurso no qual pregam a necessidade de reconhecer a multiplicidade de vozes e identidades presentes no espaço educativo, tendo como exemplo visível dessa apreensão a inserção do tema Pluralidade Cultural como um dos eixos transversais dos Parâmetros Curriculares Nacionais (PCNs).

Essas discussões em torno do assunto acompanham a complexidade vivida no mundo contemporâneo e estão inseridas em uma visão pós-moderna de sociedade amplamente marcada pela diversidade étnica, sexual, religiosa, de gênero, classes sociais, padrões culturais e lingüísticos, entre outros.

Entretanto, para alguns autores, as situações assistidas neste espaço específico demonstram que a pedagogia desenvolvida no cenário escolar ainda permanece alicerçada em práticas que ocultam ou desvalorizam as condições de vida de grupos sociais minoritários e/ou marginalizados, tornando-se um espaço que para Santomé (2004) pode ser retratado como opressor, injusto e colonizador. De acordo com este autor, a ação desencadeada pela escola, muitas vezes, contribui para legitimar as características da cultura dominante conduzindo a um processo de ocultação das diversas culturas populares.

Tendo em vista que o diálogo entre sujeitos pressupõe antes de qualquer coisa, o respeito à voz de cada um dos envolvidos/as, é que proponho que façamos uma inversão na proposta inicial desta mesa, discutindo primeiramente sobre a questão da cultura no espaço escolar, uma vez que as duas questões estão intimamente interligadas e não podem ser pensadas separadamente. Gostaria assim, de discutir como se apresentam as diferenças culturais no espaço escolar, como a escola lida com isso e que implicações se colocam para o estabelecimento de uma prática dialógica.

Antes, porém, convém esclarecer que estarei abordando o sentido do termo cultura em uma acepção plural que indica os distintos modos de vida, valores e significados partilhados pelos diferentes grupos. Sem me estender numa explicação sobre isso partirei de uma definição antropológica na qual segundo Canen e Moreira (2001, p. 18) a cultura corresponde aos "significados que os grupos compartilham, ou seja, aos conteúdos culturais. Cultura identifica-se, assim, com a forma geral de vida de um dado grupo social” (Grifo do autor). A

${ }^{30}$ Texto escrito para participação em mesa-redonda no II Seminário de Educação: Interculturalidade, políticas públicas e Educação Escolar. Rolim de Moura - Rondônia, 12 a 15 de outubro de 2009. 
essa acepção acrescentarei também o caráter político e ideológico da cultura de modo a superar o paradigma da neutralidade que a princípio comportou essa visão antropológica. Assim, mais do que o modo de vida de um determinado grupo, a cultura será definida como propõe Carlos Rodrigues Brandão (1986, p. 16) como "algo que existe e se reproduz sob determinadas condições, que espalha desigualdades e antagonismos e que pode ser intencionalmente transformada".

Neste texto, apoiada em estudos realizados durante minha pesquisa de mestrado defendida no ano de $2008^{31}$, bem como em recentes leituras, proponho-me a tecer algumas considerações sobre diversidade cultural, cultura escolar e diálogo em educação. Certamente minha intenção não é, nem poderia ser, esgotar a discussão: pretendo apenas contribuir para que nos aproximemos das principais discussões realizadas até o momento. Meu argumento central é que as reflexões sobre o panorama das escolas em relação ao tema podem nos ajudar a criar estratégias que nos aproxime de uma prática educativa que respeite as diversas culturas e seja capaz ainda de promover o diálogo entre os sujeitos.

\section{As culturas no espaço escolar}

Para iniciarmos este diálogo sobre as culturas no espaço escolar, penso que dois textos publicados no ano de 2005 em uma obra organizada por Tomaz Tadeu da Silva são importantes para fomentar a discussão. O primeiro de autoria de Jurjo Torres Santomé (2005) que tem por título "as culturas negadas e silenciadas no currículo" e o segundo escrito por Claude Grignon (2005) que tem como título "cultura dominante, cultura escolar e multiculturalismo popular". É claro que muitos autores e autoras brasileiros, principalmente Canen e Moreira (2001), Moreira e Candau (2003, 2008) e Candau (2005) têm discutido estas mesmas questões. Entretanto, os dois textos que citei são de uma clareza impressionante na maneira como abordam o assunto.

O pesquisador Jurjo Torres Santomé mostra em seu texto que o espaço escolar é marcado por uma diversidade cultural na qual convivem:

- Classes sociais: classe dominante e classe trabalhadora;

- Grupos étnicos;

- Grupos geracionais: infância, juventude e terceira idade;

- Espaço: culturas regionais, contexto urbano e "rural";

- Gênero: mundo feminino, masculino, homossexuais e lésbicas;

- As pessoas com diferenças física ou psíquica.

- Comunidades religiosas.

Todos esses grupos na opinião do autor têm suas características culturais próprias que envolvem as formas de vida, a maneira como compreendem as idéias, atitudes, linguagens, práticas, instituições e formas de organização. Além de possuírem uma gama de práticas culturais que se revelam nas formas, textos, cânones, arquitetura, mercadorias produzidas em massa, e assim por diante, tais práticas podem também ser diferenciadas de acordo com o tempo e o espaço. Assim, de certa forma a escola apresenta-se como um lugar de fronteira

31 PANSINI, F. Multiculturalismo e formação de professores/as: uma pesquisa no curso de Pedagogia da Universidade Federal de Rondônia. 152 f. Dissertação (Mestrado) - Campus de Guajará Mirim, Universidade Federal de Rondônia, Guajará-Mirim, 2008. 
cultural, de zona de contato uma vez que estas diversas culturas convivem no seu interior, não como isoladas ou puras, mas como mestiças, caracterizando a cultura escolar como uma cultura híbrida.

Se por um lado o autor considera a escola como um espaço hibrído que abriga diferentes grupos, por outro, mostra que a maior parte destas culturas se constitui como vozes ausentes nas práticas da cultura escolar. Para ele, ao analisarmos as propostas curriculares e os conteúdos selecionados na maioria das instituições escolares é possível perceber uma forte presença das culturas chamadas hegemônicas em detrimento das culturas citadas anteriormente.

Em conformidade com as exemplificações utilizadas em seu texto, as pesquisas brasileiras vêm problematizando e denunciando a tendência escolar em valorizar apenas a cultura das classes dominantes, provocando um silenciamento de vários grupos pertencentes às minorias. De acordo com Candau (2008), a educação de um modo amplo e a escola de forma particular, geralmente pouco se preocupam em discutir a cultura das minorias, seus valores e crenças uma vez que é sua tarefa principal, ao contrário disso, fazer com que tais culturas se congreguem passivamente à cultura socialmente e economicamente valorizada. Observa-se, por exemplo, uma grande preocupação em preparar para a sobrevivência em um mundo de consumo e exploração. Como aponta a autora:

\footnotetext{
Promove-se uma política de universalização da escolarização, todos/as são chamados a participar do sistema escolar, mas sem que se coloque em questão o caráter monocultural e homogeneizador presente na sua dinâmica, tanto no que se refere aos conteúdos do currículo quanto às relações entre os diferentes atores, às estratégias utilizadas nas salas de aula, aos valores privilegiados, etc. (CANDAU, 2008, p. 21).
}

Nessa perspectiva é que, do ponto de vista curricular, os conteúdos escolares dedicam uma atenção exclusiva às culturas consideradas hegemônicas ao mesmo tempo em que ocultam ou desvalorizam as culturas populares, contribuindo para que as vozes dos grupos sociais minoritários e/ou marginalizados que não dispõem de estruturas importantes de poder sejam, conforme aponta Santomé (2005, p. 161), "silenciadas, quando não estereotipadas e deformadas, para anular suas possibilidades de reação".

Ao agir desta maneira a escola passa a assumir um caráter excludente ao definir que apenas determinadas culturas e determinadas formas de conhecimento podem ser consideradas como legítimas. Nesse mote, muitas vezes os conhecimentos locais são apenas um dentre outros que não são considerados dignos de uma abordagem como, por exemplo, o conhecimento manual. Como conseqüência disso, raramente a cultura considerada legítima é aquela a que pertencem os/as alunos/as. Valoriza-se a cultura exterior ao mundo das crianças, à sua realidade local, para priorizar outras formas culturais.

Para exemplificar melhor este caráter excludente, basta que tomemos como tema de análise, entre tantos possíveis, a realidade das pessoas com necessidades educativas especiais que a partir da Lei 9394, Lei de Diretrizes e Bases da Educação Nacional tem respaldado o direito de se educarem nas redes regulares de ensino. Entretanto, a realidade vivenciada por estes sujeitos neste ambiente revela não apenas o silenciamento de suas formas de vida como tem produzido o avesso do que se espera em relação a uma prática inclusiva. A ilustração seguinte, produzida a fim de chamar nossa atenção em relação à cultura surda e a cultura das pessoas cegas é um espelho desta realidade: 


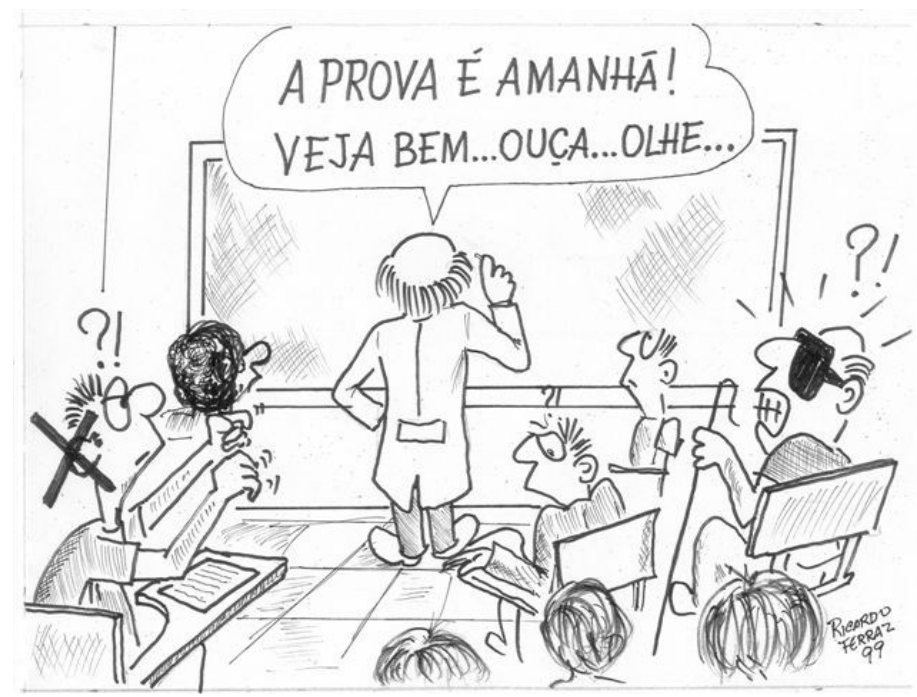

Fonte: http://www.planetaeducacao.com.br/acessodehumor/flog.asp

Justamente pelo fato de desconsiderarem as principais formas de manifestações dos alunos é que, de acordo com Santomé (2005), ainda é muito raro no espaço das salas de aula, que os/as professores/as desafiem os alunos e alunas a refletir e investigar sobre as questões relacionadas com a vida e a cultura dos grupos mais próximos do contexto local em que estão inseridos/as. Para ele, os materiais e o próprio currículo não oferecem qualquer elemento com o qual esses/as educandos/as possam se identificar - suas crenças, conhecimentos, destrezas e valores são ignorados. Em geral, o local é encarado como um estigma, algo que, dentro de uma prática colonizadora é necessário ocultar ou, pelo menos, não problematizar. Também Jean-Claude Forquim analisa que é impossível falar em uma educação multicultural crítica se não for considerada a cultura dos/as alunos/as. Segundo ele:

\begin{abstract}
Um ensino pode estar endereçado a um público culturalmente plural sem ser, ele mesmo, multicultural. Ele só se torna multicultural quando desenvolve certas escolhas pedagógicas que são, ao mesmo tempo, escolhas éticas ou políticas. Isto é, se na escolha dos conteúdos, dos métodos e dos modos de organização do ensino, levar em conta a diversidade dos pertencimentos e das referências culturais dos grupos de alunos a que se dirige, rompendo com o etnocentrismo explícito ou implícito que está subentendido historicamente nas políticas escolares "assimilacionistas", discriminatórias e excludentes (FORQUIM, 2000, p. 61).
\end{abstract}

Ampliando a linha de pensamento destacada por Santomé, em seu texto Claude Grignon (2005, p.180) estabelece um paralelo entre os principais elementos das culturas populares e das culturas dominantes. Após evidenciar as diferenças fundamentais de cada uma, o autor argumenta que as ações desenvolvidas pela escola contribuem "diretamente para o reforço das características uniformes e uniformizantes da cultura dominante, e ao enfraquecimento correlativo dos princípios de diversificação das culturas populares".

Assim, a escola conduz espontaneamente ao monoculturalismo uma vez que privilegia na escolha dos conteúdos e procedimentos escolares, dos recursos materiais selecionados, na organização do tempo e do espaço, nas experiências de ensino e aprendizagem e nas formas de avaliação, práticas restritas a cultura dominante.

Da mesma forma, a hierarquia escolar produz a supervalorização das chamadas disciplinas científicas e a secundarização dos saberes referentes às artes e ao corpo, além de reforçar o dualismo entre a razão e a emoção, entre a teoria e a prática, entre o conhecimento 
formal e a cultura erudita, promovendo a legitimação de saberes socialmente reconhecidos e estigmatização de saberes populares.

As principais características desta cultura escolar silenciadora e heterofóbica são por um lado, à produção de um espaço narrativo privilegiado e a afirmação de histórias eurocêntricas e patriarcais, identidades sociais e experiências culturais de alguns/algumas estudantes, principalmente os que pertencem à classe média e, por outro, o reforço da desigualdade e subordinação, ao mesmo tempo em que marginaliza ou apaga as vozes, as experiências e as memórias culturais dos/as assim chamados/as estudantes da "minoria".

Tendo em vista que tais práticas anulam as vozes de uma grande parcela de estudantes que freqüentam as escolas brasileiras, quais as implicações deste modo de pensar e agir em relação ao diálogo entre sujeitos?

A idéia do diálogo está implícita no ato de escutar a voz de cada um. De acordo com o dicionário Aurélio, o diálogo pode ser definido como uma "Fala alternada entre duas ou mais pessoas; conversação. Troca ou discussão de ideias, opiniões" (FERREIRA, 2001, p. 234). Para Paulo Freire (2001), o diálogo é uma relação de troca de experiências e a vivência de uma escuta respeitosa entre os sujeitos envolvidos no processo.

Ao realizar sua análise sobre a educação anti-dialógica, de certo forma Freire contribui de modo direto para o estabelecimento de relações entre os dois temas, ou seja, a valorização das culturas no espaço escolar e a possibilidade de diálogo. Para ele, a ausência do diálogo nos remete a questão da valorização e preservação das identidades dos alunos. O que eles possuem de mais relevante e que faz parte de suas histórias de vida, de suas famílias, os valores que consideram como importantes - tudo isso parece ser desconsiderado pela escola contribuindo para que haja uma perda da identidade que é um dos elementos fortes de criticidade e que faz parte de um processo de auto-afirmação de suas marcas pessoais. Nas palavras de Freire, "em geral, a escola interrompe e mesmo destrói autoritariamente esse processo, trazendo sua identidade padrão ditada por uma determinada norma culta, cuja ideologia não permite investigar e dialogar com a leitura anterior da criança" (FREIRE, 2001, p, 141).

Partindo destes conceitos e confrontando com a realidade escolar, é possível dizer que a forma como a escola trabalha com as diferenças culturais resulta na ausência do estabelecimento do diálogo. De fato, seria demagogia falar em diálogo entre sujeitos quando uma das partes apenas escuta e não tem a possibilidade de também se manifestar.

Nesse sentido, Antônio Boaventura de Sousa Santos (2000, p. 30) afirma que um dos desafios da educação contemporânea é justamente pensar sobre "como é possível realizar um diálogo inter-multicultural quando algumas culturas foram reduzidas ao silêncio e as suas formas de ver e conhecer o mundo se tornaram impronunciáveis"?

Ao fazer tal questionamento o autor parte de estudos que mostram que há uma grande contradição entre a riqueza de culturas presentes no espaço escolar e a maneira como estas culturas são reconhecidas.

Assim, seguindo a lógica da valorização de uma única cultura, aos poucos a escola foi perdendo a essência de uma prática dialógica. De acordo com Geraldi (1995), esta tendência à perda do valor da prática dialógica se dá em partes porque a escola se preocupa muito mais em encaminhar os conteúdos de ensino e não em reconhecer aquilo que os educandos podem oferecer de seu universo de convívio. Nesse sentido, as falas em sala de aula servem apenas 
para conduzir os momentos em que o professor tem por finalidade trabalhar determinado conteúdo, restringindo o verdadeiro sentindo do diálogo que é a comunicação.

\begin{abstract}
De modo geral, as falas em aula são tomadas como "meio", como atividades instrumentais de acesso e apropriação de um conhecimento que se erige como tema ou assunto destas falas. Ou seja, o diálogo (exposição do professor ou trabalho entre professor e alunos) normalmente topicaliza um certo tema. Este é considerado como o que se tem a aprender. Fala-se sobre ele; lê-se sobre ele. Nestas interlocuções afloram informações e conformações do tema. Crê-se que foi aprendido quando, com correção conceitual, sobre ele se fala, sobre ele se produz. Há no entanto outra aprendizagem implícita que se dá precisamente no processo que conduziu esta aprendizagem: porque os temas destas interlocuções são constituídos como "conteúdos de ensino" prontos, acabados, aos quais cabe ao aprendiz "aceder"; porque a interlocução de sala de aula se caracteriza mais como "aferição" de incorporação do que já estava pronto, acabado; porque os sujeitos envolvidos se sujeitam às compreensões do mundo que se lhes oferecem na escola, o que se aprende propriamente é que tudo na ciência está pronto (mi[s]tificação do conhecimento), que resta apreendê-lo e que, se não se apreende, o déficit não é das explicações científicas, mas do sujeito que explica ou do sujeito que apreende (GERALDI, 1995, p. 8).
\end{abstract}

A mesma situação descrita por Geraldi pôde ser observada em nossa realidade em duas ocasiões: na primeira, durante a pesquisa de especialização (OLIVEIRA; PANSINI, 2006) na qual se observou que a ação dialógica ficava prejudicada, pois as docentes limitavam as possibilidades de comunicação e trocas aos conteúdos que pretendiam ensinar. Por outro lado, percebeu-se que o confronto entre um conhecimento dito "científico" e o saber popular restringia o diálogo com a cultura das crianças e que na relação comunicativa o dialogo entre as docentes e entre os próprios alunos só acontecia quando autorizado pela docente.

Verificou-se nesta pesquisa, que geralmente pouco se ouve a voz dos estudantes em sala de aula. A autoridade do/a professor/a prevalece na maioria das vezes e, quando os/as estudantes são autorizados/as a falar, geralmente trata-se de um conteúdo de ensino. Raramente há espaço para que haja manifestações sobre sua própria vida.

Na segunda ocasião que ocorreu durante a pesquisa de mestrado, se observou que os currículos dos cursos de formação de professores possuem grandes limitações em relação à temática da cultura e da prática dialógica. De acordo com um dos entrevistados pela pesquisa, a discussão sobre a própria diversidade cultural não está presente nos debates que são realizados com os/as futuros/as professores/as. Nas suas palavras: "Se você pegar o projeto do curso de Pedagogia, mesmo o projeto mais recente que vem sendo discutido ele não aborda a questão de uma demanda específica local. Não se fala nesse diálogo de culturas..." (Professor A/P.V.).

Essa situação confirma a opinião de alguns autores que destacam a necessidade de desenvolver uma pedagogia multicultural, ao mesmo tempo em que lançam, como sendo um dos principais desafios para a sua construção, a pouca atenção dada ao tema nos projetos de formação de professores/as vigentes no país. De acordo com Candau (1998) as questões sobre educação intercultural e seu impacto sobre o processo de ensino não têm sido incluídas de forma sistemática nos cursos de formação docente.

A autora evidencia que, a inclusão do conceito de multiculturalismo nos cursos de formação pode beneficiar as reflexões sobre a problemática enfrentada pelos educadores/as no cotidiano escolar, relacionadas principalmente ao atendimento às diferenças.

Se o diálogo é fundamental para a valorização das culturas no espaço escolar, para a troca e para a abertura aos grupos que até o momento foram excluídos desse processo, 
devemos, a partir destes elementos, pensar e construir alternativas para a superação deste modelo escolar descrito como colonizador, monocultural, silenciador e heterofóbico.

Como aponta McLaren (2000), é preciso empenhar-se na tarefa de transformar o aspecto excludente da escola em relação às práticas culturais, econômicas e sociais nas quais os/as educandos/as estão inseridos/as. Não existe uma proposta crítica que não seja engajada com tais transformações.

Para tanto, estas alternativas precisam estar vinculadas a uma proposta que busque, além do reconhecimento das identidades que são plurais, analisar de que modo a sociedade, através de seus próprios mecanismos de desenvolvimento, como por exemplo, a fabricação da desigualdade induzida pelo capitalismo, atua na produção das diferenças. (MCLAREN, 2000).

Cabe a escola, portanto, analisar como, em nome do lucro de uma única classe dominante, tais diferenças são reforçadas e reproduzidas na escola. Embora reconhecendo a complexidade do assunto, o que evidentemente requer novas discussões, gostaria de tecer algumas considerações a título de encerramento.

\section{Finalizando: alternativas para a superação da escola monocultural}

Os estudos realizados sobre a cultura no espaço escolar mostram uma realidade em que diferentes desafios surgem em relação às diferenças culturais e o diálogo. Com relação ao tema que discutimos, fica claro que se por um lado, a diversidade cultural representa uma oportunidade de enriquecimento do espaço escolar e do próprio currículo, por outro, não se observa que esteja havendo algum tipo de esforço das instituições educativas para que estes culturas sejam acolhidas de modo a também ter voz própria neste espaço.

Assim a questão da diversidade cultural tem sido deixada às margens das próprias discussões sobre currículo que ocorrem nas escolas.

Estas reflexões apontam para a necessidade cada vez maior de buscarmos alternativas que possam privilegiar o diálogo entre os sujeitos, o conhecimento de suas especificidades de modo que as questões de identidade e de diferença não sejam pautadas unicamente pela busca de poder, mas pelo princípio da igualdade. Nessa perspectiva apontamos algumas sugestões, entre elas, que a escola possa, na medida em que se sensibilizar para esta problemática:

- Promover discussões em torno dos elementos constitutivos das identidades dos próprios professores;

- Possibilitar reflexões pessoais sobre a própria identidade e sobre como diferentes aspectos dessa identidade influenciam as experiências pedagógicas, bem como as formas de significá-las;

- Instigar a criação de novos desenhos do mapa-múndi compreendendo sua construção e explicitando o etnocentrismo nele evidenciado;

- Realizar com os/as alunos/as análises de autobiografias, narrativas pessoais, romances, poesias, músicas, filmes, anúncios, etc.;

- Estimular a participação em experiências comunitárias;

- Questionar a legitimação do conhecimento e do discurso pedagógico atual;

- Colocar o estudante em contato com diversos campos e vias do saber, da experiência, da realidade;

- Desenvolver práticas sensíveis aos valores das minorias étnicas. 
A idéia é a de que, ao olharmos e refletirmos sobre as práticas historicamente constituídas no espaço escolar, possamos ampliar a quantidade de vozes que realmente são ouvidas no espaço escolar.

Vale ressaltar que, a formação inicial desempenha um importante papel na medida em que torna possível que futuros profissionais discutam sobre essa temática. Para isso, é necessário que os currículos dos cursos de formação sejam organizados com base em categorias como cultura, conhecimento, poder, história, linguagem, diferença, discriminação, identidade; entre várias estratégias, os cursos deveriam trabalhar no sentido de:

- Oferecer cursos que abordem questões polêmicas envolvendo diversidade cultural e preconceitos, cursos sobre a história de um grupo oprimido;

- Promover mesas-redondas com a participação de pessoas de padrões culturais diversos;

- Realizar críticas de artigos polêmicos publicados na imprensa;

- Realizar análises de situações de discriminação e elaborar ensaios com a utilização de diferentes fontes;

- Analisar etnografias de escolas que atendem estudantes de distintos grupos culturais, etc.

Assim, é fundamental que os cursos de formação desenvolvam uma proposta de ensino articuladora às questões sobre educação e cultura, a partir do uso de estratégias que permitam uma formação profissional pautada na construção e na valorização de competências pedagógicas, comprometidas com a diversidade cultural, e no desenvolvimento de um ensino culturalmente relevante, ou seja, articulador de uma conciliação entre a cultura escolar e a cultura trazida de casa, a fim de instigar os/as alunos/as a fazerem "[...] um exame crítico dos processos e conteúdos educacionais e questionar qual a função deles/as na criação de uma sociedade verdadeiramente democrática e multicultural". (LADSON-BILLINGS; HENRY, 2000, p. 51 , grifos das autoras).

Enfim, não é mais possível que estejamos alheios as formas pelas quais a própria escola tem se negado a estabelecer um diálogo com seus estudantes e suas formas culturais. Portanto, penso que os educadores em conjunto com a sociedade podem se beneficiar de pesquisas como as que citei neste texto, que procuram favorecer a construção de uma escola multicultural. Se aos poucos, seja por meio de eventos como este, vamos tomando consciência das dificuldades inerentes a temática, não podemos deixar de enfrentar o desafio da exclusão a que muitas vozes são submetidas.

\section{Referências}

BRANDÃO, C. R. A educação como cultura. 2. ed. São Paulo: Brasiliense, 1986.

CANDAU, V. M. Pluralismo multicultural, cotidiano escolar e formação de professores. In: (Org.). Magistério: construção cotidiana. 2. ed. Petrópolis: Vozes, 1998, p. 237-250. Multiculturalismo e educação: desafios para a prática pedagógica. In: MOREIRA, A. F.

B.; CANDAU, V. M. (Org.). Multiculturalismo: diferenças culturais e práticas pedagógicas. Petrópolis, RJ: Vozes, 2008. p. 13-37.

Sociedade Multicultural e educação: tensões e desafios. In:

Cultura(s) e educação: entre o crítico e o pós-crítico. Rio de Janeiro: DP\&A, 2005. p. 13-38. 
CANEN, A.; MOREIRA, A. F. B. (Org.). Ênfases e omissões no currículo. Campinas, SP: Papirus, 2001.

FERREIRA, A. B. de $H$. Miniaurélio Século XXI escolar: o minidicionário da língua portuguesa. 4. ed. Rio de Janeiro, Nova Fronteira, 2001.

FORQUIN, J. O Currículo entre o relativismo e o universalismo. Revista Educação e Sociedade. v. 21, n 73, Dez. p. 2000.

FREIRE, P. Pedagogia dos sonhos possíveis. São Paulo: Editora Unesp, 2001. Professora Sim, Tia Não: Cartas a quem ousa ensinar. 3. ed. São Paulo: Olho d'Água, 1993.

GERALDI, J. W. Portos de Passagem. 3. ed. São Paulo: Martins Fontes, 1995

GRIGNON, C. Cultura dominante, cultura escolar e multiculturalismo popular. In: SILVA, T. T. da. (Org.) Alienígenas na sala de aula: uma introdução aos estudos culturais em educação. 6. ed. Petrópolis, RJ: Vozes, 2005. p. 178-189.

LADSON-BILLINGS, G; HENRY, A. Confundindo as fronteiras: vozes da pedagogia libertadora africana nos Estados Unidos e Canadá. In: TRINDADE, A. L. da. (Org.) Multiculturalismo: mil e uma faces da escola. 2. ed. São Paulo: DP\&A, 2000. p. 33-62.

MCLAREN, P. Multiculturalismo revolucionário: pedagogia do dissenso para o novo milênio. Porto Alegre: Artmed, 2000.

MCLAREN, P.; GIROUX, H. Formação do professor como uma esfera contra-pública: a pedagogia radical como uma forma de política cultural. In: MOREIRA, A. F. B.; SILVA, T. T. da. (Org.). Currículo, Cultura e Sociedade. 8. ed. São Paulo: Cortez, 2005, p. 125-154.

MOREIRA, A. F. B.; CANDAU, V. M. (Org.). Multiculturalismo: diferenças culturais e práticas pedagógicas. Petrópolis, RJ: Vozes, 2008.

Educação escolar e cultura(s): construindo caminhos. Revista Brasileira de Educação. $n^{\circ}$. 23. Rio de Janeiro, Mar/Ago, 2003. p. 156-168.

OLIVEIRA, M. de F.; PANSINI, F. O ensino da leitura e escrita numa perspectiva cultural: reflexões sobre alfabetização e letramento. Monografia de Especialização. Rolim de Moura: Universidade Federal de Rondônia, 2006.

SANTOMÉ, J. T. A imperiosa necessidade de uma teoria e prática pedagógica radical crítica: Diálogo com Jurjo Torres Santomé. In: Revista Currículo Sem Fronteiras. v. 4, n. 2, Jul/Dez., 2004. p. 5-32.

SANTOMÉ, J. T. As culturas negadas e silenciadas no currículo. In: SILVA, T. T. da. (Org.) Alienígenas na sala de aula: uma introdução aos estudos culturais em educação. 6. ed. Petrópolis, RJ: Vozes, 2005. p. 159-177.

SOUSA SANTOS, B. A crítica da razão indolente: Contra o desperdício da experiência. São Paulo: Cortez, 2000. 


\title{
EDUCAÇÃO E DIVERSIDADE: DESAFIOS À PRÁTICA PEDAGÓGICA
}

\author{
Marli Lúcia Tonatto Zibetti
}

\section{Introdução}

Há décadas temos acompanhado os processos de exclusão de uma parcela significativa de crianças e jovens que, após anos de luta pelo ingresso nas escolas, acumulam histórias de insucesso e são levados a deixá-las, ou nelas permanecendo, sentem-se igualmente alijados do direito de aprender. As causas desse fracasso têm sido atribuídas ora aos estudantes e às suas famílias, ora à incompetência de educadores e educadoras, em análises dicotômicas que ideologicamente desconsideram os demais fatores envolvidos no processo educacional.

A construção de uma escola capaz de garantir aprendizagens a todos e a todas, passa, necessariamente, pela superação das dificuldades que as escolas têm encontrado para trabalhar com a diversidade humana que se materializa no interior das salas de aula. Assim há algum tempo esta temática tornou-se alvo de investigações no Grupo de Estudos e Pesquisas em Psicologia e Educação na Amazônia - GEPPEA, pois compreender melhor as concepções e práticas presentes no interior das escolas, considerando os determinantes externos que as influenciam é condição para a superação desta trajetória de insucesso educacional.

Pretendemos neste texto, problematizar a forma como têm sido entendidas as diferenças presentes no cotidiano escolar e suas conseqüências para o fracasso, bem como as necessárias transformações nesse espaço para que seja possível construir uma educação que acolha a diversidade como elemento constitutivo das relações humanas.

\section{Diversidade e Fracasso Escolar}

É tema corrente na atualidade o direito à diversidade, o respeito às diferenças, a inclusão de todos e todas nos processos educacionais. No dicionário (HOUAISS, 2001) o termo diversidade é definido como "a qualidade daquilo que é diverso, diferente, variado, conjunto variado, multiplicidade". Ou seja, basta que olhemos uns aos outros para constatarmos que somos diferentes em muitos aspectos que vão desde os biológicos (sexo, problemas orgânicos, etnia) até a diversidade nas histórias de vida, na cultura ou nas condições sociais de existência. A diversidade nos constitui enquanto seres humanos, pois para sobreviver transformamos a natureza pelo trabalho e assim produzimos cultura. Ou seja, diferentes formas de trabalhar e viver originam modos diversos de pensar, vestir, comer, sentir, expressar, etc.

$\mathrm{Na}$ educação, muitas vezes, as discussões sobre diversidade são travadas em contextos a-históricos em que se parte do princípio de que todos têm as mesmas 
oportunidades e a solução dos conflitos se daria pela aceitação das diferenças que nada teriam a ver com a questão econômica ou social. Assim a inclusão é discutida apenas do ponto de vista escolar, como se as instituições educacionais não estivessem inseridas em uma sociedade excludente e injusta. Discute-se a diversidade de religião, gênero e etnia, descolada da questão social. Ou seja, os pobres podem ser incluídos desde que aceitem ocupar os espaços da forma que lhes forem destinados pelos que possuem o poder de "conceder esse direito" e desde que aceitem as regras que vigoram nesses espaços, sem questioná-las.

Costa (2008) esclarece que ao longo dos últimos vinte ou trinta anos as normas políticas e econômicas em vigor têm produzido um grande contingente de excluídos, "uma massa de expurgados" como efeito colateral da ordem e do progresso econômico. Esses "outros" e "outras" têm sido descritos/as como atrasados/as, subdesenvolvidos/as, pobres, prémodernos/as, primitivos/as, violentos/as, improdutivos/as, etc. "A globalização produziu e continua a produzir um 'refugo humano' que precisa ser descartado, jogado no lixo, e talvez sem chances de reciclagem" (COSTA, 2008 p. 494).

Àqueles e àquelas que não se encaixam nos modelos sociais pré-estabelecidos pelo sistema produtivo, restam os encaminhamentos aos sistemas de saúde cujos profissionais da área psi descrevem, classificam, nomeiam, medem, diagnosticam e tratam os problemas de conduta explicados como anomalias, desvios da ordem. São pessoas que não se adéquam às diferentes instâncias das instituições sociais produtivas e, portanto, são encaminhados aos setores encarregados de receber e readaptar os que necessitam de uma nova forma de funcionamento. (COSTA, 2008).

Desta maneira também são vistas as crianças e jovens que não são alcançados/as pela pedagogia em vigor em nossas escolas e continuam a ser encaminhados/as aos/às médicos/as e psicólogos/as e ao reforço escolar, ou laboratórios de aprendizagem. $E$ assim, conforme alerta Costa (2008) ao mesmo tempo em que a sociedade tem produzido uma legislação e um discurso cada vez mais avançados no sentido de acolher as diferenças, também temos produzido nas escolas um numeroso conjunto de "outros" que não conseguimos incluir no processo de aprender.

\footnotetext{
Como a diferença não é uma marca no sujeito, mas algo que se constitui nas formas de "olhar", o aprimoramento das técnicas de ver, das lentes dos especialistas, e a proliferação de óticas possibilitadas pela sociedade da mídia e do espetáculo, vêm permitindo apreciar um sempre crescente contingente de "outros", antes invisíveis. Aliás, enxergar, marcar, classificar e retirar da sala de aula essas diferenças emergentes, que perturbam a velha ordem da escola moderna, tem sido uma das estratégias adotadas pelas professoras e professores para poder controlar e civilizar um grupo menor de alunos "normais" que permanecem relativamente acomodados em suas carteiras (COSTA, 2008, p. 495).
}

Para a autora, se faz urgente discutir o fenômeno da "proliferação da diferença" no cotidiano escolar, para além da visão de que a diferença está sempre em alguns "outros" como os negros, os índios, os deficientes físicos. A diferença na escola também está servindo para identificar os alunos e alunas que não se enquadram nos padrões escolares. Como a escola não sabe lidar com eles e elas, procede aos encaminhamentos para as terapias capazes de "torná-los" normais. Estes encaminhamentos têm contribuído para que a escola justifique sua incapacidade de ensinar a estas crianças e jovens os conhecimentos considerados válidos. Ocorre que o número de sujeitos "fora dos padrões" está cada vez maior e isso leva ao questionamento da lógica vigente. 
Embora a produção teórica que tem combatido esta leitura das "diferenças" no espaço escolar a partir dos trabalhos de Patto $(1997,1999)$ tenha alcançado relevância nacional como evidenciam os muitos trabalhos desenvolvidos por uma abordagem crítica de psicologia escolar (SOUZA, 1997; MACHADO, 1997, 2007; COLLARES; MOYSĖS, 1996; MOYSĖS, 2001), aspectos apontados pela autora na obra "A produção do fracasso escolar - Histórias de submissão e rebeldia" ainda não foram superados.

$\mathrm{Na}$ verdade, o que vemos no ambiente educacional brasileiro é a agudização desse quadro. Pois, se de um lado as crianças de seis a catorze anos encontram-se dentro da escola, de outro vemos que a escola continua sem condições de garantir aprendizagens aos sujeitos que outrora expulsava. E se antes eles eram excluídos pelas constantes reprovações, hoje a escola não sabe o que fazer com eles dentro da escola e continua encaminhando-os para os serviços de psicologia ou então para os Conselhos Tutelares, cujo poder de intervenção tanto no âmbito do sistema de saúde, quanto na instituição familiar, os tem transformado em mais uma instância para solicitação de socorro por parte das escolas.

Sabemos que os professores e as professoras exercem um papel político e ético estratégico no processo de ensino e estão diretamente implicados com os resultados desse trabalho. Entretanto, entendendo-se a educação como conseqüência de um conjunto de elementos que se conjugam e estão intimamente relacionados, pensamos que outras instâncias do processo educacional precisam ser envolvidas como co-responsáveis por esse quadro. Referimo-nos aqui aos elaboradores das políticas públicas e ao conjunto dos profissionais envolvidos de alguma forma com a educação, desde os gestores até os pesquisadores. Conforme destaca Costa (2008, p. 496):

\footnotetext{
Vendo-se a educação formal institucionalizada como um poderoso espaço narrativo, os discursos que aí circulam produzem e reforçam as desigualdades. As disciplinas escolares, seus conteúdos, rituais e práticas, bem como as formas de gestão e administração das escolas e dos eus estudantis, são territórios marcados por hierarquias e perversas estratégias de subordinação e marginalização. Os discursos dominantes da cultura, como tem sido o caso dos "saberes que realmente valem" - $\square$ as disciplinas -, ou das "visões de mundo verdadeiras" - $\square$ as narrativas da filosofia ocidental, por exemplo, a do sujeito moderno centrado e racional -, circulam no espaço escolar como se fossem completamente "naturais", indiscutíveis, livres de qualquer suspeita.
}

Estas questões precisam ser levadas em conta quando discutimos a emergência de termos diferentes no cenário das pesquisas e estudos educacionais para que não ocorram transformações apenas na aparência e deixemos intactas as estruturas de opressão e exclusão.

Este alerta é importante no momento em que vemos que as transformações no mundo contemporâneo, especialmente aquelas relacionadas à globalização das informações, associadas às constantes migrações e imigrações de grandes contingentes de pessoas por diferentes motivos, sejam aqueles decorrentes de conflitos bélicos, políticos ou religiosos, bem como das crises econômicas, têm levado cada vez mais as pessoas a conviverem com grupos culturalmente distintos, influenciando e sendo influenciadas pela diversidade, em maior ou menor grau, dependendo das relações de poder existentes entre elas.

Estes cenários têm trazido à tona discussões relativas às relações culturais no processo educacional, influenciando as produções teóricas sobre monoculturalismo, multiculturalismo e interculturalismo. Necessário se faz, entretanto, advertir que, embora os termos sejam recentes, a preocupação com esta problemática não é nova no Brasil, visto que 
a construção de um projeto educacional que tome como ponto de partida a cultura dos sujeitos envolvidos encontrava-se no cerne da produção teórica de Paulo Freire desde a década de 1960. Admitimos que a complexidade das relações sociais e interculturais do mundo contemporâneo gera novas formas de elaboração do conhecimento no campo da pesquisa e da prática pedagógica. O que questionamos, porém, é a contribuição que estas produções têm trazido para o cotidiano escolar.

Não podemos permitir, nesse novo cenário de conceitos e termos emergentes, a predominância de abordagens que desconsiderem como as culturas hegemônicas alcançaram tal status. Ou seja, o domínio de uma cultura sobre outra é decorrência do poder econômico e político dos grupos sociais que as representam. Assim, não é possível uma abordagem crítica de mudança no contexto educacional sem que se considerem as profundas desigualdades econômicas da sociedade brasileira, como afirma Gatti (In CAIADO, 2008, p. 368): "Reconhecimento e respeito à diversidade não quer dizer descompromisso com desigualdades que aviltam a própria condição humana."

Do ponto de vista educacional a diversidade não tem sido entendida como uma riqueza, mas sim como um problema, uma dificuldade, pois os sujeitos cujos comportamentos não atendem às expectativas dos educadores, sejam nos ritmos de aprendizagem, nos comportamentos adotados em sala de aula, na condição financeira, ou na composição de seu "grupo familiar" têm um percurso problemático no âmbito escolar. E são essas diferenças que são trazidas à tona quando se discutem as razões do fracasso, conforme evidenciam os fragmentos recortados das entrevistas realizadas com educadores/as durante pesquisas em escolas públicas da rede Estadual de Rolim de Moura.

\section{FRAGMENTO 1}

Entrevistadora: Por que você acha que esses meninos estão parados no processo de alfabetização?

Orientadora Educacional: [...] eu acho que são esses problemas familiares mesmo, essa carência deles eu percebo assim que aquele aluno que o pai acompanha a mãe acompanha o rendimento dele é outro, agora aqueles que os pais nunca vão, vão só pra matricular esses alunos geralmente são aqueles que dão problema na aprendizagem e comportamento. A gente já chegou a essa conclusão, a gente mesmo fala na questão da aparência: aquele aluninho sujinho, sabe aquele ali? Possivelmente ele vai ser um aluno que vai ter dificuldade de aprendizagem e de comportamento. Não é questão de camiseta furada, chinelinho havaiana, a gente está falando de higiene mesmo né? Esses alunos a gente já meio que conseguiu diferenciar ele.

\section{FRAGMENTO 2}

Entrevistadora: E na tua opinião, porque que você acha que essas crianças não atingiram o que se esperava delas nesse contexto dos dois anos da alfabetização...

Coordenadora Pedagógica: [...] ó pode até dizer assim que vai ficar piegas o que vou dizer agora, mas eu acho que continua sendo o contexto familiar [...] é no contexto familiar, quer dizer, geralmente são crianças, filhos, que moram só com a mãe [...] são geralmente crianças 
que os pais, às vezes, a gente diz às vezes porque a gente não vai afirmar, que às vezes esses pais não têm estrutura nenhuma em relação ao cuidado com essas crianças.

\section{FRAGMENTO 3}

Entrevistadora: Porque você acha que essas crianças não conseguem aprender, não conseguem acompanhar a turma?

Coordenadora Pedagógica: Porque eles são mais lentos, até o raciocínio. Às vezes a questão familiar! Então é onde o professor teria que realmente se desdobrar em cima desse aluno, mas na verdade isso não acontece porque infelizmente, eu digo isso mesmo porque eu sou assim muito clara nas minhas colocações, a gente não tá sabendo trabalhar porque nós, professores, já parece que estudamos e mesmo tendo aí pessoas que estão trabalhando em cima disso e vendo a questão do aluno que precisa de mais ajuda, parece que a gente tá preparado pra trabalhar com a criança que não dá trabalho.

\section{FRAGMENTO 4}

Entrevistadora: Como é que vocês se sentem em relação aos resultados do processo de alfabetização obtido por esta escola?

Professora 1: A criança vem pra sala sem o básico. O básico que eu digo é o caderno e o lápis, os outros materiais, um lápis de cor, uma cola. Você não vai fazer a criança escrever a tarde inteira né, nem vai ficar só falando, mas esses outros materiais, um lápis de cor, uma cola né, ele não tem.

Professora 2: A escola tem que dar.

Professora 1: Têm uns que acham que a escola tem obrigação de dar o lápis deles, o caderno; eu tenho aluno que vem descalço pra escola, tem dia que ele traz o caderno, tem dia que não traz. E a mãe já foi chamada várias vezes...

Professora 3: A família não liga!

Professora 1: [...] é direto a criança não tem! E como é que deixa a criança vir pra escola sem material? Vai fazer o quê na escola?

Professora 2: A maior preocupação nossa na escola, que eu percebi, é que a família está preocupada com o trabalho, falta de diálogo em casa, porque se o pai está presente ou a mãe, ou uma avó, mesmo que está sem pai mas se tem uma avó que cativa: "Oh! meu filho você vai pra escola pra aprender, você é capaz!" Não, isso a gente não tem.

No discurso das educadoras comparecem preconceitos que indicam como as diferenças são explicadas na escola. As crianças que não avançam no processo educacional são aquelas provenientes de famílias que destoam do estereótipo de família perfeita composta por pai, mãe e filhos; aquelas que não aparentam a higiene esperada pela escola, que não trazem o material "necessário", ou ainda, são lentas "até o raciocínio". E como afirma a própria educadora "a gente tá preparado pra trabalhar com a criança que não dá trabalho". Conforme Pereira e Backes (2008, p. 02):

A grande questão é como transformar esse espaço que ainda reproduz preconceitos e estereótipos, que exclui os que nele não se adéquam, em um espaço no qual se 
construa a cidadania plural, na qual diferentes pessoas, de diversas culturas e vozes interajam, sem que as suas diferenças sejam motivo de opressão.

O espaço escolar é um espaço de intercultura no qual acontecem transformações, desconstruções e hierarquias. O que somos e pensamos, nossas aspirações e ações, enfim nossas identidades são construídas pelas relações sociais de poder. E essas relações são travadas em contextos diversos e à educação não cabe apenas o papel de reprodutora das desigualdades sociais em desigualdades escolares. É possível (e necessário!) encarar a escola como uma realidade histórica que pode ser transformada pela ação humana e assim assumir a perspectiva de que a educação pode colaborar e participar do processo de emancipação do homem.

Mas para que isso ocorra, precisamos ampliar o foco de nossas análises considerando as condições em que funcionam atualmente nossas escolas públicas: que espaços físicos e pedagógicos existem para que possamos discutir a diversidade que desafia o trabalho homogêneo realizado em nossas salas de aula? Que formações têm recebido nossos professores e professoras para que construam este olhar plural, esta capacidade de atender de forma criativa as diversas demandas de um conjunto tão diverso de sujeitos?

Nossas vivências nas instituições escolares nos autorizam a dizer que não temos conseguido construir esta escola. Continuamos fazendo uma escola igual para os diferentes. Organizamos classes de primeira série, fornecemos aquele tempo e aquele conteúdo da mesma forma para todos, e aqueles ou aquelas que não derem conta de responder às metas estabelecidas são considerados problemáticos e julgamos não ser nossa responsabilidade ensiná-los.

Assim fazemos a escola, da educação infantil ao ensino superior. Como modificar este funcionamento de forma a atender os ritmos, as necessidades, as dificuldades de cada um? Como retirar das quatro paredes de uma única sala e da responsabilidade de um só professor ou professora os resultados obtidos pelos alunos e alunas? Que modificações serão necessárias nos espaços, nas condições e nos tempos dessas escolas para que seja possível aproximar os pontos de chegada de quem foi obrigado a sair de pontos de partida tão diversos?

\section{Algumas provocações, a título de encerramento...}

As políticas públicas de universalização da escolarização sempre vieram atreladas à defesa de superação das desigualdades sociais por meio da educação. E este discurso tem contribuído para que as famílias, crianças e jovens que freqüentam a escola, apeguem-se a esta promessa e tenham expectativas de ascensão social a partir do acesso à escola.

O que temos visto nos últimos anos é que estas expectativas não se cumpriram e as discussões agora se voltam para a qualidade do ensino oferecido nas escolas públicas. Entretanto, a discussão deste problema não tem sido feita de forma ampla e nem têm sido considerados os inúmeros estudos produzidos sobre a problemática do fracasso escolar, seja do ponto de vista da psicologia ou da sociologia. Os mesmos preconceitos denunciados há tempos pelas pesquisas nas referidas áreas, permanecem intactos nos discursos de educadores e da classe política, apenas com a diferença de que os primeiros apontam para as famílias e as crianças como as responsáveis pelo fracasso, enquanto os últimos 
responsabilizam unicamente os educadores e a precária formação dos mesmos pelos péssimos resultados obtidos.

Conforme afirma Leonardo Boff (2001, p. 09):

\begin{abstract}
A cabeça pensa a partir de onde os pés pisam. Para compreender, é essencial conhecer o lugar social de quem olha. Vale dizer: como alguém vive, com quem convive, que experiências tem, em que trabalha, que desejos alimenta, como assume os dramas da vida e da morte e que esperanças o animam. Isso faz da compreensão sempre uma interpretação.
\end{abstract}

Nossas análises são sempre construídas a partir do lugar que ocupamos e este olhar parcial, incompleto, faltante, precisa ser modificado pela convivência com o outro, pela aproximação com as distintas realidades que nos envolvem. A nós professores e professoras falta uma aproximação ao cotidiano dos alunos e alunas, à vida real que vivem fora da escola, para que não continuemos esperando trabalhar com "modelos" idealizados de aprendizes, construídos teoricamente ou a partir de vivências adultocêntricas, culturalmente marcadas por visões de classe, idade, grupo social e/ou religião.

Aos políticos falta o contato com o "chão" das inúmeras escolas existentes nesse país. Desde aquelas que funcionam embaixo de lonas e folhas de palmeira nos acampamentos de Sem Terra, Sem Tetos e outros tantos grupos cuja identidade tem sido forjada na luta pelos seus direitos, até aquelas construídas e esquecidas pelo poder público nas periferias urbanas que não têm atendidas suas necessidades mais elementares como água, carteiras, cadeiras, livros, espaços físicos para atividades diferentes e acesso à tecnologia, condições indispensáveis para a construção de uma escola de qualidade.

Aos pesquisadores e pesquisadoras falta assumir a parceria com as instituições escolares de educação básica de forma a fazer chegar até elas as inúmeras produções teóricas esquecidas nas prateleiras das bibliotecas universitárias, ou nas livrarias, tão longe dos profissionais a quem se destinam, cujos salários mal garantem a manutenção das necessidades básicas de sobrevivência. Cabe às instituições de ensino superior, assumir de fato a articulação entre ensino, pesquisa e extensão, pois a excessiva valorização da pesquisa tem transformado as universidades em excelentes produtoras de críticas e renovação imensa de conceitos. Entretanto a responsabilidade de levar estas produções ao cotidiano escolar, revendo-as à luz dos problemas cotidianos e assim contribuindo para forjar as mudanças necessárias, não tem sido assumida pelos pesquisadores, com louváveis exceções. Ou seja, temos produzido muitos discursos sobre diversidade, mas nossas ações têm se caracterizado como exploradoras, colonizadoras e centradas na valorização do conhecimento científico e acadêmico. Conforme defende Barbosa (2008, p. 05)

\begin{abstract}
As novas perspectivas sobre as culturas da infância, as culturas familiares e a cultura escolar podem, certamente, nos auxiliar a pensar em um novo modelo de escolarização de qualidade para as crianças brasileiras, que entreteça culturas e não as negue. Uma escola que seja plural, mas não excludente. Uma escola que possa "escutar" as crianças e se construir para e com elas. Que escute o barulho do confronto, faça emergir os mal-entendidos, compreenda as diferenças nos modos de recepção e significação, ajuste as lógicas de cada grupo cultural, analise as relações de poder e hierarquia entre eles, proponha processos de inserção social de todos.
\end{abstract}

Entendemos que ainda há um longo caminho a ser percorrido para que possamos efetivamente construir processos de escolarização que permitam a pluralidade de vozes no espaço escolar. E este é o desafio que nos anima a seguir adiante. 


\section{Referências}

BARBOSA, Maria Carmem Silveira. Culturas da Infância. Disponível em www.portalensinando.com.br/ensinando/principal/conteudo.asp?id=5479 Acesso em 04 out. 2008.

BOFF, Leonardo. A águia e a galinha: uma metáfora da condição humana. 37. ed. Petrópolis, RJ: Vozes, 2001.

CAIADO, Kátia Regina Moreno. Práticas pedagógicas: a diversidade na escola inclusiva. In. PERES, Eliane. et al. (Org.) Trajetórias e Processos de ensinar e aprender: sujeitos, currículos e culturas. Livro 3. Porto Alegre: EdiPUCRS, 2008. (p. 361-375).

COLLARES. Cecília A. L.; MOYSÉS. Maria Aparecida. A. Preconceitos no cotidiano escolar: ensino e medicalização. São Paulo: Cortez, 1996.

COSTA, Marisa Vorraber. Currículo e Pedagogia em tempos de proliferação da diferença. In PERES, Eliane. et al. (Org.) Trajetórias e Processos de ensinar e aprender: sujeitos, currículos e culturas. Livro 3. Porto Alegre: EdiPUCRS, 2008. (p. 490-507).

HOUAISS, Antônio; VILLAR, Mauro Salles. Dicionário Houaiss da língua portuguesa. Rio de Janeiro: Objetiva, 2001.

MACHADO, Adriana Marcondes. Avaliação e fracasso: a produção coletiva da queixa escolar, in: AQUINO, J. G. (Org.) Erro e fracasso na escola: Alternativas teóricas e práticas. São Paulo: Cortez, 1997. (p.73-89).

MACHADO, Adriana Marcondes. Novos possíveis no encontro da psicologia com a educação. São Paulo: Casa do Psicólogo, 2007.

MOYSÉS, Maria Aparecida Afonso. A Institucionalização invisível: Crianças que nãoaprendem-na-escola. Campinas, SP: Mercado das Letras; São Paulo: FAPESP, 2001.

PATTO, Maria Helena Souza. A produção do fracasso escolar: Histórias de submissão e rebeldia. São Paulo: Casa do Psicólogo, 1999.

. Para uma crítica da razão psicométrica. Psicologia USP. v. 8, n.1, 1997, (p. 47-62).

PEREIRA, Renilda Lino; BACKES, José Licíno. Educação Intercultural: Uma construção possível! Disponível em http://www.rededesaberes.org/eventos/anais/textos/pdf/GT\%20\%202/EDUCA \%C7\%C3O\%20INTERCULTURAL \%20UMA \%20CONSTRU\%C7\%C30\%20POS S\%CDVEL.pdf> Acesso em 11 de out. 2008.

SOUZA, Marilene Proença Rebello de. A queixa escolar e o predomínio de uma visão de mundo. In: MACHADO, A. M; SOUZA, M. P. R. (Org.). Psicologia escolar: em busca de novos rumos. São Paulo: Casa do Psicólogo, 1997. (p.17-34). 


\title{
TER, FAZER E PENSAR A EXPERIÊNCIA: UMA SAÍDA EPISTEMOLÓGICA PARA COMPREENDER O COTIDIANO E TODA A SUA DIVERSIDADE
}

\author{
Orestes Zivieri Neto
}

Esse estudo é resultado de recentes reflexões desenvolvidas acerca das pesquisas nos/dos/com os cotidianos das escolas tendo em Oliveira e Alves (2008) suas mais nobres representantes no Brasil, as quais procuram fundir aos trabalhos de Josso (2004) na discussão sobre "Experiências de Vida e Formação" e também à formação docente com a discussão de Tardif (2004) sobre saberes docentes, em especial os saberes da experiência.

Nosso desafio é sem dúvida olhar para o cotidiano e, mais particularmente, para as experiências construídas no e a partir dele, mergulhando o mais profundamente possível, para dele vislumbrar toda a complexidade e conexões a que estão sujeitos todos esses saberes. Não queremos negar o cotidiano em todas as suas possibilidades, como servis investigadores da lógica do paradigma moderno, sem antes fazer o que diz Alves (2008), que para compreender a complexidade do cotidiano é preciso: "o sentimento do mundo", "virar de ponta cabeça", "beber em todas as fontes" e "narrar a vida e literaturizar a ciência". E, de forma magnífica, explica:

\begin{abstract}
O modo de "ver" dominante no mundo moderno deverá ser superado por um "mergulho" com todos os sentidos no que desejamos estudar, a este 'mergulho' temos chamado, pedindo licença ao poeta Drumond, de 'o sentimento do mundo [...] Querer saber mais, buscando respeitar aquilo que Lefrebvre (1991) chama de 'a humilde razão do cotidiano', [...] exige do/a pesquisador/a, a isto dedicado, que se ponha a sentir o mundo e não só a olhá-lo, soberbamente, do alto. Não há para nós a postura do isolamento da situação possível a outra postura epistemológica. Nós também estamos vivendo e produzindo conhecimento no cotidiano. Assumir, portanto, esse nosso compromisso e comprometimento são garantia de que não vamos nos iludir com uma possibilidade inexistente. Não há outra maneira de se compreender a lógica do cotidiano senão sabendo que nela estamos inteiramente mergulhados. [...] Buscar entender, de maneira diferente do aprendido, as atividades do cotidiano escolar ou do cotidiano comum, exige que estejamos dispostos a ver além daquilo que os outros já viram e muito mais: que sejamos capazes de mergulhar inteiramente em uma determinada realidade buscando referências de sons, sendo capazes de engolir sentindo variedades de gostos, caminhar tocando coisas e pessoas e se deixando tocar por elas, cheirando os cheiros que a realidade vai colocando a cada ponto do caminho diário.
\end{abstract}

Queremos apenas "ter experiências" sem tê-las provocado; outras vezes provocando "fazer experiências" e, finalmente depois, para nosso deleite "pensar sobre as experiências" (JOSSO, 2004, p. 51).

Pedimos, então, licença para o nosso primeiro mergulho no compromisso de "narrar a vida e literaturizar a ciência", flexionar ora o "nos" tão difundido pela ciência moderna, ora o "eu" em minhas vivências, em meu mergulho.

Por essa razão e, levando em conta todo o nosso contágio por essa torrente de informações e experiências, apresentamos esse artigo, dividido em duas seções, da seguinte 
forma: Na primeira parte intitulada: Vamos ao fato. Saberes da experiência - aproximo os trabalhos das pesquisas nos/dos/com os cotidianos, com os trabalhos de Tardif (2002), mais especificamente os saberes da experiência. Na segunda: É preciso coragem. Alçando o primeiro vôo - trago a narrativa de uma experiência vivida e tento analisar a luz da teoria de Josso (2004), já citada acima.

Esperamos que, objetivamente, o nosso texto possa de alguma forma servir como análise para todos os neófitos, como eu, dessa nova tendência epistemológica que emerge. $E$ agora vos convido a mergulhar ou alçar esse primeiro vôo comigo. Decidam-se, o tempo urge e não podemos vacilar. Todos e todas estão convidados.

\title{
Vamos ao fato. Saberes da experiência
}

De todas as tipologias de conhecimento/saberes dados (TARDIF; LESSARD; LAHAYE, 1991; TARDIF, 2002; PONTE, 1994, 1995; SHULMAN,1998; GAUTHIER et al, 1998), a que naturalmente encontra maior dificuldade em postular-se, é sem dúvida alguma, o saber da experiência, evidentemente por sua fonte de referência originar-se do e no cotidiano. Parte disso deve-se ao fato do paradigma moderno considerar conhecimento somente aqueles validados pela ciência, colocando em xeque todos os demais conhecimentos que, por ventura, não se enquadrarem em seus padrões epistemológicos. A exemplo do que nos diz Alves (2008, p.16):

\begin{abstract}
Aprendemos com todos os setores dominantes, durante os últimos quatro séculos, que os modos como se cria conhecimentos nos cotidianos não tem importância ou estão errados e, por isto mesmo, precisam ser superados. Isso se traduz em uma situação na qual não os notamos, achando que é 'assim mesmo'. Resulta que não fixamos, não sabemos como são e, menos ainda, sabemos como analisar os processos de sua criação ou como analisá-los para melhor compreendê-los. Além disso, esses conhecimentos são criados por nós mesmos em nossas ações cotidianas o que dificulta uma compreensão de seus processos, pois aprendemos com a ciência moderna que é preciso separar, para estudo, o sujeito do objeto. Esses conhecimentos e as formas como são tecidos exigem que admitamos ser preciso mergulhar inteiramente em outras lógicas para apreendê-los e compreendê-los.
\end{abstract}

O desafio reside, portanto, em afirmar e ao mesmo tempo insistir, e não negar, que os saberes da experiência, tanto quanto as pesquisas nos/dos/com o cotidiano escolar são espaçotempo $^{32}$ de saber, criação, imaginação, memória, solidariedade e acima de tudo de grande diversidade e vivo.

Ainda que os saberes da experiência, oriundos das classificações de Tardif (2002), sejam de uma classe profissional, no caso dos saberes docentes, sua natureza reside no fato de originar-se do trabalho cotidiano dos professores que, em sua lida diária em sala de aula constroem, criam, modelam, readaptam, improvisam, etc., situações que são validadas pelo próprio processo de aprendizagem de seus alunos constituindo, assim, um campo de certezas e estratégias para enfrentar os inusitados da vida cotidiana.

\footnotetext{
32 Termo cunhado por Nilda Alves e Inês Barbosa de Oliveira (2008, p.11) e que mantemos a sua explicação. "A junção de termos e sua inversão, em alguns casos, quanto ao modo como são 'normalmente' enunciados nos pareceu, há algum tempo, a forma de mostrar os limites para as pesquisas nos/dos/com os cotidianos, do modo dicotomizado criado pela ciência moderna para analisar a sociedade."
} 
Em suas características trazem a marca de serem plurais, porém, inicialmente é preciso considerar como diz Larrosa (2002, p.27):

[...] Por isso, o saber da experiência é um saber particular, subjetivo, relativo, contingente, pessoal. Se a experiência não é o que acontece, mas o que nos acontece, duas pessoas, ainda que enfrentem o mesmo acontecimento, não fazem a mesma experiência. O acontecimento é comum, mas experiência é para cada qual sua, singular e de alguma maneira impossível de ser repetida. O saber da experiência é um saber que não pode separar-se do indivíduo concreto em quem encarna.

O saber da experiência origina-se, preliminarmente, de um processo de aquisição "[...] no modo como alguém vai respondendo ao que vai the acontecendo ao longo da vida e no modo como vamos dando sentido ao acontecer do que nos acontece" (Ibidem, p.27). E é ai, exatamente, que temos a sua desvalorização, pois o conhecimento do qual temos entendimento e do qual se tornou paradigma da sociedade moderna é objetivo, nos é externo e é tal qual uma mercadoria que pode ser adquirida, consumida, apropriada, por todos e todas.

Nesse sentido, seu desprestígio encontra-se justificado em sua subjetividade que, no caso de uma categoria profissional, pode pluralizar e diversificar um ambiente de trabalho que, eminentemente, se constituiria em um espaçotempo de saber, criação, imaginação, memória, solidariedade e, acima de tudo, de grande diversidade e vivo (como já dissemos acima).

Por essa razão, não se pode idealizar ou hipotetizar a realidade, como se fosse possível simulá-la; é necessário que essa análise privilegie os saberespráticas ${ }^{33}$ dos sujeitos cotidianos que, dado à sua condição contextual e sob a perspectiva complexa é também capaz de objetivar o mundo em que vive, pois como nos diz Najmanovich (2001, p. 93-94, apud FERRAÇO, 2007, p.9-10):

\begin{abstract}
O sujeito, desde a perspectiva das ciências da complexidade, é uma "unidade heterogênea", organização emergente da interação de suborganizações entre as quais se destacam a cognição, a emoção e a ação, que são as formas de interação do sujeito com o mundo. "O sujeito não é um ser, uma substância, uma estrutura ou uma coisa senão um devir nas interações". O sujeito não é o dado biologicamente, mas o construído no intercâmbio em um meio social humano, que por sua vez está em interação constante com outros contextos. É através dos vínculos sociais de afeto, de linguagem, de comportamentos que o sujeito vai se auto-organizando.
\end{abstract}

Na classificação proposta por Tardif (2002, p. 49) define-se saberes da experiência como o "conjunto de representações a partir das quais os professores interpretam, compreendem e orientam sua profissão e sua prática cotidiana em todas as suas dimensões“.

Dessa forma, ao constituir-se profissional, todo o conhecimento, concepção e ou crença formadora estarão predispostas ao enfrentamento de situações concretas, que comumente não são aventadas, concebidas e definidas e, naturalmente, exigirão uma parcela de improvisação e de habilidades pessoais e também de capacidades para resolver situações variáveis e transitórias.

A exemplo do que nos diz Tardif, Lessard e Lahaye (1991, p. 220):

(...), o(a)s próprio(a)s professore(a)s, no exercício de sua função e na prática de sua profissão, desenvolvem saberes específicos, fundados em seu trabalho cotidiano e no conhecimento de seu meio. Esses saberes brotam da experiência e são por ela validados. Eles incorporam-se à vivencia individual e coletiva sob a forma de habitus e de habilidades, de saber fazer e de saber ser. Podemos chamá-los de saberes da experiência ou da prática.

\footnotetext{
${ }^{33}$ Termo cunhado por Nilda Alves e Inês Barbosa de Oliveira (2008).
} 
Destaca-se também que, em razão dos saberes docentes envolverem diversos tipos de ações que demandam competências do professor, e por serem essencialmente não idênticos e tampouco mensuráveis, passa-se assim, a solicitar das circunstâncias diárias certas sabedoria para argumentar e para agir conforme os fatos, os afetos, as normas e os papéis. Desse modo, torna-se, impossível o estabelecimento de unidade racional de ações.

Os saberes da experiência, por estarem, então, em ação direta com a prática, colocamse em uma posição formadora, pelo fato de se revelarem como um processo de aprendizagem inicialmente decidido por mim em minha formação anterior. Dentro desses conhecimentos, que podem ser retraduzidos ou adaptados, a fim de resolver os problemas da prática educativa, elimino o que me parece inútil. A partir daí escrevo minha história, através do estilo que desenvolvo ao ensinar, dentro das técnicas e procedimentos que passarei a utilizar, ou mesmo nas marcas pessoais, que estabelecerei como profissional e que "(...) se expressam, então, através de um saber ser e de um saber-fazer pessoais e profissionais validados pelo trabalho cotidiano" (TARDIF, 2002, p.181).

Assim, essas idéias aqui tramadas - pesquisa nos/dos/com o cotidiano e saberes da experiência trazem a marca de que, nos devidos espaçostempos, tecem a vida e constroem os saberesfazeres ${ }^{34}$ dos indivíduos que nela se inserem. A tentativa de aproximação se justifica por ambas sofrerem as mesmas discriminações epistemológicas, pois na primeira teríamos a ordem dos saberes imanentes dos sujeitos ordinários do cotidiano, no outro, ainda, que se coloca o mesmo sujeito no patamar de uma categoria profissional, seus saberesfazeres são de igual forma relegados a uma pseudo-epistemologia ou subciência.

\section{É preciso coragem. Alçando o primeiro vôo}

Tal como passarinho alçando o primeiro vôo e, ao mesmo tempo, imaginando-se um competentíssimo beija-flor, que ao plainar em pleno vôo, em um esforço indescritível de manter-se plainado sob um mundo gigantescamente em movimento e difícil de captar, tamanha a sua complexidade. É na imagem do impossível olhar do beija-flor, não da perspectiva estática e paralisante, mas da possibilidade do olhar mais alargado possível, para captar o mundo vivo em um movimento estonteante, que podemos ao final, como numa atitude de pleno gozo, sobrevoar as agora enormes flores, para delas extrairmos o néctar do pólen e seguirmos nossa viagem extasiante.

Com o mesmo sentimento do pequeno pássaro em seu primeiro vôo e também o pequenino, mas competente beija-flor (sem querer parecer presunçoso) submirjo-me com essa metáfora no universo miúdo, mas complexo e grandioso do cotidiano, para dele extrair experiências, como nos indica Josso (2004, p.51), ao sugerir as modalidades de elaboração para a devida compreensão do processo de construção da experiência:

a) "ter experiências" é viver situações e conhecimentos durante a vida, que se tornaram significativos, mas sem tê-los provocados.

b) "fazer experiências" são as vivências de situações e acontecimentos que nós próprios provocamos, isto é, somos nós mesmos que criamos, de propósito, as situações para fazer experiências.

\footnotetext{
${ }^{34}$ Termo cunhado por Nilda Alves e Inês Barbosa de Oliveira (2008).
} 
c) "pensar sobre as experiências", tanto aquelas que tivemos sem procurá-las (modalidade a), quanto aquelas que nós mesmos criamos (modalidade b).

Para explicar tal processo, adiciona um jogo de entendimento sob as perspectivas das construções das experiências no âmbito da elaboração a posteriori e a priori, que intentaremos elucidar.

Numa primeira etapa, diz que estaríamos no nível das experiências construídas a posteriori, caracterizada como um momento de "suspensão de automatismo" porque, na verdade, interromperá com uma lógica que não nos permite integrá-la a ordem do conhecido, deixando-nos de certa forma "afetivamente perturbados" - é então o que denominamos imprevisto, espanto. Alerta-nos quanto à possibilidade de compreender as etapas que serão desencadeadas entre o momento em que estivermos focalizados, e naturalmente, o uso que faremos do que foi extraído da vivência.

$\mathrm{Na}$ segunda etapa seria o estado decorrente do fato de ter vivido uma situação particular e começar "uma análise interior do que foi experimentado, sentido, observado seletivamente." (Ibidem, p.52)

E na terceira etapa, após o esforço de interiorizar o desconhecido, colocamo-nos na condição de estar com outros, no processo natural de interação humana, que se vale da linguagem para simbolizar ao outro o que se passou e o que aprendemos com a experiência, num total empreendimento de interpretação social e cultural da experiência.

Já na quarta etapa, teríamos o armazenamento da experiência juntamente com as demais variantes ou, então, seu enquadramento em uma nova categoria, entretanto, com a possibilidade de transferências para outros contextos, ou ainda de dinamizá-la para eventuais situações.

Quanto à experiência construída a priori, Josso (2004) nos dirá que se trata da experiência científica e a experiência de formação em situação educativa. Acrescenta ainda que sua distinção quanto ao processo a posteriori reside no fato de iniciar previamente com a formalização, nomeação ou simbolização da experiência, valendo-se de observações e práticas de conhecimento. "É o grau de sistemática e de organização, bem como de adequação dos meios metodológicos ao objeto de experiência, que, neste ponto, fará a diferença quanto à qualidade ou à precisão entre as experiências desta categoria". Para desfechar as idéias apontadas por Josso (2004, p. 53), a mesma acrescenta a modalidade seguinte:

\begin{abstract}
"Pensar as suas experiências" (modalidade c) diz respeito não a uma experiência, a uma vivência, particular, mas a um conjunto de vivências que foram sucessivamente trabalhadas para se tornarem experiências. Neste campo, reflexões como: "o que eu extraio como conhecimento e saber-fazer do conjunto destas experiências?", por exemplo, orientam o trabalho biográfico, qualquer que seja a temática escolhida (exemplos: a história de minha formação, a história de minha relação afetiva, a história de minha relação ao trabalho, a história de minha relação ao meu corpo e à minha saúde, a história de meus projetos, a história de minha criatividade etc.).
\end{abstract}

Com essa perspectiva, passo a narrar à experiência por qual passei e, que, dado a nossa contaminação pelo paradigma das ciências moderna, enquadrá-la-ia no campo de problemas não formalizados pela investigação supracitada, insistindo em que dado a nossa cegueira intelectual, preliminarmente, ou enxergo todos os fatos mensuráveis para posterior análise, ou seleciono apenas aqueles que dizem respeito à temática de meu interesse, impedindo de vê-lo sobre todas as suas arestas. Essa narrativa enquadra-se perfeitamente na 
modalidade "ter experiência", sem tê-la previamente provocada, conforme descrição dada por Josso (2004), e sua temática encontra-se arraigada na grande maioria das pesquisas em educação.

Dia: $17 / 04 / 2008$.

Naquela manhã assistiria a duas aulas com a professora Claudia e duas com a professora Rita. Realizei os registros com a professora Claudia nas duas primeiras aulas e tudo transcorreu dentro da normalidade possível. A professora Rita, com quem iria após o intervalo anunciou-me que daria uma aula com calculadora. Como tinha preocupação de que muitos não trouxessem, pediu à coordenação pedagógica umas cinco emprestadas, pois iria trabalhar em dupla. O sinal tocou encerrando com o intervalo.

Lá fui eu e a professora Rita para sala do $6^{\circ}$ Ano, duas aulas geminadas. No caminho, a professora me anunciava, para o meu espanto, que havia nessa sala garotos de apenas 11 a 12 anos de idade na média ${ }^{35}$, alunos com sérios problemas com o Conselho Tutelar, alguns até pagando pena. É claro que apesar dos meus interesses de estudos serem outros, essa discussão deixou-me com algumas indagações que se juntavam a outras conversas com os demais professores da escola a despeito da violência na escola.

Pus-me a perguntar: "O que está acontecendo com a Escola? Por que a escola não tem conseguido, juntamente com a família, superar esse problema? Por que a família se distancia cada vez mais da escola e, ainda. a julga como má formadora e preparadora de seus filhos?"

Entramos na sala e a professora, após cumprimentá-los e eu me dirigir ao final da sala, levantou quantos haviam trazido calculadora e, como imaginava muitos sequer haviam se lembrado. Tranqüilizou-os dizendo que havia pedido algumas emprestadas para escola. Pediu então, em seguida, que formassem duplas e, enquanto distribuía as calculadoras para as duplas que estavam sem, que eles revissem as atividades dadas na aula anterior.

Isso tudo em meio a um barulho ensurdecedor, pois todos falavam ao mesmo tempo e a professora, sempre muito cordial, solícita, amável e calma, pedia para se tranquilizarem e ficarem em seus lugares.

Ao meu lado estava a dupla em que dois dos garotos me surpreenderiam. Apesar dos incessantes apelos da professora para que os dois ficassem em seus lugares aguardando a chegada da calculadora, quando viram que faltaram exatamente 02(duas) calculadoras, apesar de a professora estar garantindo que iria buscar as que estavam faltando, no meio de sua fala, o garoto Luís levantou-se e disse:

-A senhora ta doida, quanto tempo to falando aqui, ô? A senhora não me enxerga não?

A professora apesar de ouvir tudo isso, foi rapidamente a direção, trouxe as duas calculadoras e entregou às duas duplas que estavam sem o equipamento.

Logo que Luís pegou a calculadora, começou apertar todas as teclas ao mesmo tempo e, ao chegar à carteira, a batê-la sobre a mesa. Interrompi a aula da professora pedindo licença e dirigindo-me a Luís, isso com a professora já junto de mim, pedi-lhe que entregasse ao seu amigo, pois ele não sabia mexer e tampouco valorizar o que era público.

\footnotetext{
${ }^{35} \mathrm{Na}$ média, pois naturalmente existem em quantidade muito pequeno alguns com idade superior, tipo 14 anos. 
Luís fingia não nos ouvir, ficava cantando baixinho e, depois de muita insistência nossa, passou a calculadora ao amigo, mas vez ou outra a tomava numa pura demonstração de insatisfação, revolta ou sei lá o quê.

Foi então que a professora solicitou-me que falasse com eles sobre a responsabilidade do material escolar, que era público e, portanto, de que mais gente necessitaria, por exemplo, daquela calculadora.

A aula da calculadora dado pela professora Rita ficou muito legal porque, fora a atividade instrumental de uso da calculadora, pudemos também falar de política pública educacional e de forma interessante, com a participação de alguns alunos.

O sinal bateu encerrando a aula e, antes de ir embora a professora Rita pegou o caderno de Luís e escreveu um bilhete para seus pais, afim de que a escola pudesse conversar com os mesmos.

Dirigindo-se à sala dos professores, a professora Rita disse-me que seria muito bacana se eu pudesse estar no dia em que os pais do garoto viessem e eu me coloquei a disposição.

A experiência colocava-nos diante daquilo que o cotidiano não dá conta de prever, exatamente por não ser estático e nem tampouco mecânico. Também mostrava-nos o quão multifacetado pode ser um olhar, e aí sim estatizante, pois pode retratar apenas um fio do emaranhado complexo da grande teia, que compõe o nosso universo do dia-a-dia. Imersos em nossas indagações tentamos interpretar o acontecido, buscando em nossos fundamentos referencias que explicasse o ocorrido.

Nossa narrativa continua, demarcando, para isso, o espaço da experiência ocorrida em sala de aula e fora dela. Destacamos apenas, que motivados por uma série de outras narrativas sobre a violência, surgidas na sala dos professores em razão do acontecido, mergulhamos na história do Luís na tentativa de elucidar e também verificarmos as medidas adotadas pela escola.

A professora Rita chamou a Coordenação Pedagógica e vieram a Orientação e a Supervisão Escolar e, em meio a tantos incidentes que ultimamente têm ocorrido na escola, falavam com uma naturalidade sobre o episódio que me instigava.

No entanto, quando indaguei sobre o histórico de Luís para a Orientadora, todos foram unânimes em afirmar que, após a retirada das medidas disciplinares da escola, eles estavam à mercê da Justiça e do Conselho Tutelar.

E aí a minha surpresa dobrou, triplicou, quando a orientadora referindo-se ao histórico do Luís disse:

- Olha professor, a última vez aconselhei, o pai e a mãe, a pedirem auxílio a um psicólogo, para podermos ter acesso a algumas medidas que, tanto a escola quanto eles, família, poderiam ter para ajudar o Luís. Na verdade, continuou, o Luís é adotivo dessa família, que conhecia muito o seu pai. A mãe verdadeira, após a separação virou prostituta e não quis mais saber dele, a ponto de hoje não morar mais aqui, fiquei sabendo, recentemente, que está na Espanha. O pai foi para Curitiba procurar emprego e melhorar de vida, deixou o Luís com alguns parentes; chegando lá não se sabe por que se suicidou e o garoto sequer viu mais o pai. A família atual do Luís diz não agüentar mais e você vê, também, que a escola não sabe mais o que fazer.

Acrescentou ainda, agora a Supervisora, que o garoto Luís havia vindo de outra escola a qual, para não expulsá-lo, tinha realizado uma troca com um outro garoto que, pasmem, no 
ano anterior tinha invadido a sala dos professores e colocado veneno na garrafa de café, já analisado pela justiça inclusive. Luís, logo depois da troca entre as escolas, ao chegar no $5^{\circ}$ Ano, pegou seu estilete e passou no braço de um outro colega de sala, que lhe rendeu uma pena que cumpre no Centro Neurológico de Pessoas Portadoras de Deficiência da cidade.

Fui para casa nesse dia com o coração dilacerado e com a cabeça pegando fogo. Em outro dia, retornando à mesma escola, fui informado de que não me ligaram quando da vinda dos pais adotivos do Luís, pois ambos disseram à coordenação pedagógica que já não agüentam mais e estão pensando em entregá-lo ao Conselho Tutelar para uma nova adoção. Novamente o espanto e novamente as indagações: "o que fazer?" O que está acontecendo com as familias e as escolas? Ainda sem respostas para tais indagações, em minhas andanças pelas escolas, vez ou outra tenho me deparado com histórias meio semelhantes.

Saio dessa forma do mergulho, mas ainda com a roupa totalmente encharcada, trazendo uma série de perguntas, no momento, sem respostas. Talvez possamos continuar a pensar nas medidas que a escola pública pode adotar para melhorar essa questão que tanto a aflige.

Quanto a mim e a professora Rita, após a vivência da experiência, temos pensado e aprendido com as histórias de violências que às vezes se iniciam nos próprios lares de nossas crianças, marcando suas vidas para sempre e as nossas também. De tudo, reconhecemos, que dado à complexidade dos contextos socioculturais existentes, cada vez mais nos damos conta de nossa pequenez no trato cotidiano e, nesse caso, com todo o tipo de violência que nos ronda.

\section{Considerações finais}

À saída do mergulho, ainda que encharcado, há sempre um caminho para o autoconhecimento, pois, ao tentar encontrar as raízes lógicas para entender as multifacetas do cotidiano, enxergo-me como que inventando o cotidiano no espaçotempo em que me insiro nos saberesfazeres que vou construindo sozinho e em interação com outros e tudo isso é universal, posto que ninguém escapa der ter experiências e pensar sobre elas.

Assim, a ciência moderna nega esses saberes por que os enxerga sob a ótica objetiva, em que sujeito e objeto são coisas distintas, e a subjetividade contamina a racionalidade de fazer ciência.

No entanto, cada vez mais no damos conta que não se trata de uma negação, mais sim de uma miopia que reduz e paralisa o cotidiano, pois o enxerga sob a parcialidade do automatismo dos atos. Poderíamos, sim, dizer que o automatismo diário é, realmente, um recurso bastante óbvio do cotidiano, pois permite o ordenamento e a classificação do dia-a-dia a ser gerido por cada indivíduo. E esses indivíduos não fazem e não são sempre do mesmo jeito, estão em constantes mutações e isso não seria resultado de suas cotidianidades em movimento?

Se relegarmos os sujeitos do cotidiano à condição de meros reprodutores de seu dia-adia, apenas por considerarmos suas subjetividades, não teríamos a própria evolução cientifica comprometida?

Mas esse texto não é e não foi uma discussão entre o valor dos saberes científicos e saberes cotidianos, senão uma tentativa de diálogo que consiga produzir uma epistemologia 
metodológica nos/dos/com os cotidianos, elevando assim mais a condição de se fazer investigações, que sejam capazes de colocar os sujeitos em meio as suas subjetividades e objetividades.

Por essa razão buscamos nos trabalhos de Oliveira e Alves (2008), Ferraço (2007) e Garcia (2008) fundamentações que argumentem a favor da consolidação de práticas investigativas, que tragam um novo olhar aos saberes da experiência construídos nos/dos/com os cotidianos.

Intentamos a narrativa de uma experiência, de acordo com Josso (2004), sem nenhum tipo de provocação, que nos tem feito refletir sobre os nossos atos, pensamentos, atitudes, olhares, etc.

Finalmente, longe de esgotar essa discussão que, por sua natureza polêmica instiga a cada vez mais buscarmos a nossa auto-formação podendo, assim, aprimorar os nossos olhares, nossos ouvidos, nossos mergulhos, nossos vôos, nossos sentimentos, etc., mostrando-nos o cotidiano como é modesto, mas complexo; único, mas diverso; pequeno, mas grandioso; individual, mas plural, homogêneo, mas heterogêneo etc.

\section{Referências}

CERTEAU, M. A invenção do cotidiano I: artes de fazer. Petrópolis: Vozes, 1994.

CARCIA, Regina L.; ZACCUR, Edwiges. Cotidiano e diferentes saberes. Rio de Janeiro: DP\&A, 2006.

GARCIA, Alexandra. Em busca das escolas na escola: por uma epistemologia das "balas sem papel". Educação e Sociedade, Campinas, v.28, n.98, p.1-17, jan./abr.2007.

FERRAÇO, Carlos E. Pesquisa com o cotidiano. Educação e Sociedade, Campinas, v. 28, n.98, p.1-21, jan./abr.2007.

JOSSO, Marie-Christine. Experiência de Vida e Formação. São Paulo: Cortez, 2004.

MAURíCIO. Lúcia V. et al. (Org.) Vozes da Educação. Memórias, histórias e formação de professores. Petrópolis: DP/Rio de Janeiro: Faperj, 2008.

OLIVEIRA, Inês B. Certeau e as artes de fazer: as noções de uso, tática e trajetória na pesquisa em educação. In: OLIVEIRA, I. B.; ALVES, N. Pesquisa no/do cotidiano das escolas: sobre redes de saberes. Rio de Janeiro: DP\&A, 2008. p. 49-64.

OLIVEIRA, Inês B.; ALVES, Nilda. Pesquisa no/do cotidiano das escolas: sobre redes de saberes. Rio de Janeiro: DP\&A, 2008.

TARDIF, Maurice. Saberes docentes e formação profissional. Petrópolis: Vozes, 2002.

TARDIF, Maurice.; LESSARD, Claude.; LAHAYE, Louise. Os professores face ao saber: um esboço de uma problemática do saber docente. Teoria e Educação: Porto Alegre, $n^{\circ} 4,1991$, p.215-233. 


\section{DIÁLOGO INTERCULTURAL: CURRÍCULO, INCLUSÃO DIGITAL E IDENTIDADE CULTURAL}

Neide Borges Pedrosa

\section{A experiência que motivou a pesquisa}

$\mathrm{Na}$ base da presente reflexão situa-se uma primeira experiência de inclusão digital com docentes indígenas na REN - Representação de Ensino, localizada em Ji-Paraná / Rondônia, no ano de 2006.

Trata-se de um curso oferecido pelo NTE - Núcleo de Tecnologia Educacional da REN, em parceria com o Programa de Informática Aplicada à Educação - PROINFO/MEC, com carga horária de 36 (trinta e seis) horas.

Teve por objetivo motivar e instrumentalizar docentes indígenas para o uso do computador como ferramenta auxiliar da prática pedagógica escolar; docentes e lideranças indígenas, naquela ocasião já estavam se mobilizando e preparando suas escolas para implantar as TIC - Tecnologias da Informação e da Comunicação. Em suas aldeias já haviam sido instalados um gerador e computadores para os serviços administrativos.

De certa forma, estavam sensibilizados para incorporar a informática à suas práticas escolares, de modo que os artefatos tecnológicos pudessem agregar valor às atividades de formação das novas gerações pelas quais são responsáveis.

A aldeia mais próxima de Ji-Paraná fica a sessenta quilômetros do meio urbano do Município; outras, que têm o território bem extenso, vão até o limite do Estado do Mato Grosso e muitas chegam a se espalhar por vários estados da região. O transporte terrestre é dificultado por estradas ruins e, no tempo das águas, tornam-se atoleiros. Os que moram a aproximadamente duzentos quilômetros da cidade usam barcos, passando, às vezes, todo um dia dentro deles, quando não há enchentes. Do contrário, ficam impossibilitados de chegar ao município, pois, não conseguem atravessar os rios.

Como se vê, apesar de motivados, existia uma série de dificuldades, relativas ao contexto, para os docentes indígenas participarem do curso desenvolvido.

A capacitação dos indígenas foi realizada durante três meses, nos últimos três dias úteis de cada mês. Nesses dias, os docentes indígenas vinham à cidade para receberem seus salários do Estado; costumavam, porém, passar tempos sem o fazerem, pois, não consideravam o salário a questão mais importante da vida deles; em conseqüência faltavam ao curso..., quando a data do pagamento coincidia com a colheita da castanha do Pará a maioria deles faltava porque a tradição da colheita falava mais alto.

A capacitação, com apenas 36 (trinta e seis) horas foi uma prévia em termos dos primeiros contatos com o computador; apesar de terem boa vontade e disposição para 
aprender vários fatores prejudicaram o desenrolar do curso; por faltarem muito, quando voltavam para as já poucas aulas mensais haviam se esquecido muito do que fora "aprendido".

Outros fatores estiveram presentes nesta experiência, ora dificultando ora facilitando o proposto. Em especial, há de se destacar a questão da dimensão cultural, mais especificamente, a da comunicação entre professoras multiplicadoras do órgão regional de ensino e docentes indígenas. Os diferentes dialetos de uma língua de forte tradição, e na qual são alfabetizados na própria escola, exigiu que se recorresse, em muitas situações, aos intérpretes durante o curso, de modo a se evitar desistências, evasões.

Por outro lado, foi programado um conteúdo básico que lhes permitisse interagir com a máquina e com os outros (e-mail, msn, etc). Ao mesmo tempo em que viviam uma experiência prazerosa de descobertas houve quem questionasse o direito de escolher o que queria aprender.

$\mathrm{Na}$ avaliação do curso, a maioria dos docentes indígenas manifestou-se satisfeita, interessada e até solicitou mais oportunidades de aprenderem usar a Internet, demonstrando compreender o alcance desta conquista.

No entanto, alguns consideraram a proposta como algo imposto a eles e queriam discutir e decidir pelo conteúdo do curso e não, submeterem-se a um estudo "decidido pelo branco".

As professoras multiplicadoras "bem intencionadas" depararam-se com este posicionamento, apesar de interagirem com a expectativa positiva dos indígenas em relação aos benefícios que os computadores poderão trazer para as escolas de suas aldeias.

Não se chegou, propriamente, a um impasse, mas, o sentimento aí manifestado serviu como um alerta para a equipe responsável pela experiência: a questão não diz respeito apenas à preocupação de se "conectar" a escola indígena ao mundo globalizado pela tecnologia, nem apenas de se respeitar o direito, do cidadão indígena, de ter acesso aos avanços científicos e tecnológicos. Vai mais além: reclama o olhar responsável, crítico, cidadão de uma busca de inclusão digital que respeite a diversidade e as múltiplas culturas.

\section{Potencializando o tema com uma postura interdisciplinar}

Na condição de Professora Assistente da Universidade Federal de Rondônia - Campus de Ji-Paraná, cujo Mestrado em Ciências e Práticas Educativas voltou-se para a pesquisa acerca do uso da informática em educação, é que se acompanhou a experiência antes relatada.

Chamou especial atenção o fato de que o docente indígena, além de não querer continuar à margem das novas tecnologias - computadores e outras mídias - anseia por produzir material didático específico em sua língua e voltado para a preservação de sua cultura, lutando pelo direito à identidade de seu povo.

Neste contexto, enquanto povo indígena que luta para ser reconhecido como povo, que possui cultura e jeito de ver o mundo diferenciado, têm clareza de que precisam ter acesso às tecnologias e informações do mundo globalizado, até para se fortalecerem e lutar por seus interesses e sobrevivência. Ou seja, a preservação de sua cultura e de sua autonomia pressupõe o acesso ao conhecimento, de forma também autônoma, contrapondo-se a uma "conquista" manipulada quando tal processo não se dá através de um diálogo intercultural. 
A experiência de capacitação de docentes indígenas em Ji-Paraná, então, gestou um projeto de pesquisa mais complexo: como promover a inclusão digital dos povos indígenas da Terra Igarapé Lourdes, em Ji-Paraná / Rondônia, fundando-se numa premissa de humanização pela tecnologia?

Quais pressupostos, e em que área do conhecimento buscá-los, seriam capazes de embasar uma política inclusiva, ao mesmo tempo, marcada por um compromisso emancipatório?

Sentiu-se, por isso, necessidade de recorrer a áreas de conhecimento cujo objeto de estudo oferecesse conteúdo para se responder a determinados questionamentos, indispensáveis à sistematização do referencial teórico da pesquisa em andamento.

Daí buscar-se interlocução com a questão da identidade cultural como pressuposto para a elaboração de currículos coerentes com as premissas da educação contemporânea, preocupada com a superação dos mecanismos de controle e dominação que dão suporte à sociedade de mercado em que, hoje, se vive.

Mas como essa mesma sociedade, por força do avanço científico e tecnológico, tornouse uma sociedade da informação e do conhecimento, entrecruzam-se valores e crenças por vezes conflitantes, caracterizando-se, este cenário, por um dado nível de complexidade que reflete, e torna também complexa, a prática pedagógica escolar.

Por isso mesmo, o projeto de pesquisa Diálogo Intercultural: currículo, inclusão digital e identidade cultural trabalha uma proposta que vai além de simples constatação, que não se reduz a uma abordagem metodológica descritiva, focado apenas na caracterização de como a tecnologia da informação está chegando na aldeia indígena.

Acreditando que a evolução tecnológica e humana só tem sentido se for alicerçada num processo de emancipação humana, adota-se uma perspectiva crítica ao reconhecer que a tecnologia, tanto serve para a emancipação como para a dominação.

Neste sentido, reconhece, também, na situação concreta das escolas indígenas da Terra Igarapé Lourdes de Ji-Paraná / Rondônia, que o computador se torna um elo imprescindível de ligação entre aquela comunidade e o mundo, sem se alienar de sua realidade, desde que sua chegada se dê no contexto de uma visão crítica e reflexiva.

Enquanto importante ferramenta cognitiva, além do desenvolvimento da aprendizagem, poderá promover uma integração bem sucedida que torne possível o registro e o resgate da cultura daquela aldeia.

Além disso, poderá promover sua cidadania, colocando-os em contato com outras aldeias num processo importante de troca de informações através da Internet, que possibilite arregimentar forças na luta por suas causas, num autêntico movimento emancipatório.

Para cumprir a função socializadora da educação escolarizada as instituições precisam mediar o acesso aos conhecimentos que promovem a inserção dos sujeitos no seu meio e no momento histórico em que vivem.

A educação o faz selecionando, organizando, desenvolvendo práticas e processos avaliativos que se constituem mecanismos sociais que provêm de espaços mais amplos e que no seu interior refletem valores e crenças a serem internalizados em função de interesses que extrapolam o espaço escolar (SACRISTÁN, 2000).

Dessa forma, concilia interesses dos que estão sendo inseridos socialmente com os interesses dos que com isto se beneficiam: os grupos dominantes, que para se sustentarem, tanto econômica quanto politicamente, precisam de sujeitos engajados no seu tempo e 
espaço. Com escolhas conscientes ou não a educação participa desse processo, sendo, em certa medida, responsável pela reprodução da sociedade à qual serve.

Para Sacristán (2007) a globalização acentua desigualdades que estão na base das relações entre povos e culturas, levados a reafirmar seus traços culturais, ao se defenderem dos enfrentamentos postos por uma interdependência marginalizadora, excludente. Por isso mesmo, embora se fale de "escolhas" aqui se reconhece o fato de que a transformação em curso resulta de uma conjugação de fatores que afetam o modo de vida da aldeia, suas necessidades e práticas, as quais demandam um esforço de integração, uma superação de condições objetivas de exclusão.

Esse esforço de integração não se dá sem enfrentamentos e sem exacerbação de traços culturais; a cultura e a vontade desses povos, submetida à imposição de um fenômeno globalizador que suprime a diversidade compõe um cenário que não pode ser desconhecido da educação ao definir o currículo. Ou melhor, a educação é diretamente afetada pelas mudanças decorrentes do processo de globalização, principalmente porque os critérios de inclusão passaram a ser determinados pela lógica de mercado, prevalecendo-se os critérios de produtividade e de competitividade (SACRISTÁN, 2007).

Isso acarreta novas exigências, tais como, reconstruir permanentemente a visão de realidade, desenvolver uma análise crítica do conceito de cultura na escola o qual tem se ampliado com o objetivo de os sujeitos se sentirem incluídos, compreender como os comportamentos básicos de transmissão de saberes se alteram com os recursos tecnológicos, hoje, disseminados (SACRISTÁN, 2007).

Aprofundando-se na análise das novas exigências que colocam para a educação na sociedade contemporânea, é preciso reconhecer o papel central do professor na configuração da prática educativa escolar.

Sacristán (2000) considera que mesmo "moldados" pelo currículo produzido pelo contexto mais amplo, o docente, na condição de sujeito ativo também o influencia, pois, é o docente quem traduz, na prática, tal currículo.

Com isso se quer dizer que o compromisso do educador para com seus alunos, além da dimensão técnica que possui, tem uma dimensão política: ele escolhe os caminhos mais significativos para os alunos e constrói uma prática pedagógica que deixa de ser neutra, na medida em que, buscando torná-la significativa para os alunos ele precisa articulá-la com seu meio, expectativas, interesses - ou seja, com sua cultura - e, a partir daí emerge um compromisso com o meio social concreto em que vivem.

O fenômeno da globalização precisa ser compreendido quando se quer discutir a prática educativa escolarizada, ou seja, as diferentes dimensões do currículo no cotidiano da escola.

Essa busca de compreensão passa, inicialmente, por uma discussão conceitual, que, se supõe, seja capaz de referenciar a análise do impacto do fenômeno sobre as políticas públicas definidas (e levadas a efeito) em relação às práticas pedagógicas que acontecem no interior das escolas.

O termo "globalização", entre tantos outros conceitos pelos quais tem sido abordado, no dizer de Burbules e Torres (2004, p.11), diz respeito ao "surgimento de novas formas culturais, de meios e tecnologias de comunicação globais, todos os quais moldam as relações de afiliação, identidade e interação dentro e através dos cenários culturais locais". 
A partir do conceito selecionado - não por acaso - pode-se admitir que, na sociedade contemporânea, contradições e conflitos entre o "local" e o "global" tornam-se mais evidentes, na medida em que as práticas sociais tendem, cada vez mais, a se submeterem a "mudanças" que não refletem, necessariamente, escolhas dos sujeitos sociais nelas envolvidos. Isso porque a ideologia da "inevitabilidade" cuida de impedir que a autonomia dos Estados resista a uma nova ordem mundial, afetando a cultura e a educação de cada um.

Cumpre, aqui, então, esclarecer o motivo da seleção de tal conceito: pretende-se discutir, no contexto de uma pesquisa acerca do uso das TIC - Tecnologias da Informação e da Comunicação, em escolas de duas aldeias indígenas da Amazônia, como vem se dando, no Brasil, a interlocução entre a inclusão digital e os valores locais, entre a cultura globalizada e as necessidades, interesses, expectativas dessas comunidades.

Buscar-se-á interpretar e compreender os significados visíveis e os latentes que o docente indígena a elas atribui, bem como, o sentimento que experimentam, ao usá-las, frente ao desafio de serem contemporâneos ao mesmo tempo em que preservam sua cultura.

Nesse sentido é que a globalização precisará ser considerada na pesquisa proposta: até que ponto esse processo ameaça a capacidade de resistir dos indígenas? É possível transformar o ensino e a aprendizagem da escola indígena, conectá-la com seu tempo e com um espaço mundializado, sem distanciá-la de sua cultura e práticas sociais?

Há de se reconhecer, entretanto, que a "aldeia global" dos dias de hoje supõe compartilhar experiências muito além das circunstâncias locais, que tornam o longe algo muito próximo, o conhecimento mediato em saberes imediatos, interrelações entre os muito diferentes e os desiguais, tudo isso mediado pelas tecnologias da informação e da comunicação.

Como compartilhar experiências, no entanto, difere-se do significado atribuído ao conceito de globalização, ao longo dos estudos em andamento dever-se-á aprofundar nas concepções que aí se entrecruzam de modo a se ter clareza de como, num mundo marcado pelo rápido avanço científico e tecnológico, o professor indígena participa e promove a inclusão digital em sua Terra. As dimensões, contradições e conflitos presentes nessa transformação das práticas sociais das aldeias indígenas em discussão, indicarão suas escolhas em termos de formação de professores e currículo da escola indígena.

O que já se percebeu, na experiência que deu origem à pesquisa, é que autonomia e resistência estão presentes no cenário dessa realidade mais particular que se tornou objeto de estudo da referida pesquisa.

O significado social da experiência educativa é discutido por Apple (2006), reportandose ao pensamento de Bourdieu: analisa que o sociólogo francês faz uma avaliação nãoromântica das relações de classe que permeiam a relação existente entre cultura, poder e economia na educação e na sociedade como um todo.

Pode-se depreender a partir das análises de Apple (2006) e do conjunto de leituras que embasam o presente estudo, que apesar do caráter de organização responsável pela reprodução da ordem social e econômica dominante, este fenômeno não tem a neutralidade, a ingenuidade que, aparentemente, pode-se supor que tenha.

Para o autor, Bourdieu teve o mérito de pôr em evidência a complexidade das relações entre cultura, economia e poder, realizando uma análise estrutural que permite compreender possibilidades e limitações da educação no contexto das conexões que se dão entre conhecimento e poder. 
Ele faz uma análise que denomina de "relacional" - aquela que envolve compreender a atividade social "ligada ao grande grupo de instituições que distribuem recursos, de forma que determinados grupos e classes têm sido historicamente ajudados" (APPLE, 2006, p. 44). Defende que categorias ideológicas e econômicas, essenciais para a produção de agentes que exercem os papéis econômicos e que, também, produzem significados alienantes (úteis para uma atuação sem muitos questionamentos) participam da construção destas relações, que são hegemônicas.

Os educadores, numa análise que faz com base no pensamento de Gramsci, participam desse grupo como intelectuais que se articulam organicamente com o poder. Ou seja, por trás da instituição escola e através de seus agentes, conhecimentos são selecionados, reinterpretados e distribuídos sem a declarada e pretensa neutralidade científica, numa ação política e direta em termos de relação entre capital cultural e controle econômico e social.

Assim, a concepção de dimensão hegemônica do currículo "como um todo de valores, crenças e ações de fora da instituição de ensino, aceitos via conhecimento senso comum pelos agentes educacionais, compromissados com a ordem econômica e social que contextualiza sua prática" (APPLE, 2006, p. 43-44) permite, aqui, afirmar que tais agentes distanciam-se do papel emancipador que, acredita-se, todo processo educativo deveria assumir.

O pensamento pedagógico contemporâneo pode contribuir para tal estudo, para a busca de resposta para tais indagações, de modo especial, no Brasil, com a concepção emancipadora de educação de Paulo Freire.

Trata-se de uma concepção que, privilegiando uma abordagem ampla do conceito de educação isto é, que vai além de um processo restrito ao domínio escolar, assume um caráter emancipatório, na medida em que propõe a transformação da sociedade, ao se comprometer com sujeitos sociais dominados.

Paulo Freire defende uma pedagogia do oprimido, consubstanciada numa postura crítica cuja visão de mundo seja condição para se "desnaturalizar" a marginalização e a exclusão. Uma postura que exige clareza política em diálogo com uma dada competência, no sentido de que a apropriação de uma leitura crítica possa mediar saídas alternativas viáveis e realistas.

Segundo Freire (1980) essa proposta corresponde a um movimento em que uma consciência historicamente condicionada pelas estruturas dominantes rompe com as condições objetivas, provocando conflitos indispensáveis à emergência de uma percepção estrutural da realidade. No seu dizer, "é alentador tratar de desmistificar a realidade: é o processo pelo qual aqueles que antes haviam estado submersos na realidade começam a sair, para se reinserirem nela com uma consciência crítica." (FREIRE, 1980, p. 75)

Além da opção por uma educação libertadora enquanto princípio uma proposta crítica supõe uma ação transformadora. Com isto se quer dizer ser necessário uma prática pedagógica humanizadora, dialogal, entre sujeitos, que não repita a relação dominante dominado da sociedade mais ampla no espaço da educação, da formação humana.

A prática pensada, para Paulo Freire, seria então um permanente movimento de construção de uma educação emancipadora, seria a abordagem metodológica fundamental para se estabelecer um currículo comprometido com a cidadania, uma vez que num 
comportamento co-intencional professores e alunos voltar-se-iam para a realidade como sujeitos, buscando conhecê-la de maneira crítica e dialogal.

Com as concepções de Paulo Freire muitas outras entrarão em interlocução, quando do aprofundamento no estudo do tema ora tratado, de modo a se compreender processos e práticas pedagógicas e, a partir daí, discutir a formação enquanto elemento essencial para se efetivar uma concepção teórica de currículo que corresponda à educação requerida pela imensa maioria das sociedades, neste terceiro milênio.

No bojo do pensamento freireano estão os pressupostos para o uso das TIC numa perspectiva crítica e emancipatória. Mas, entre os autores que, especificamente, tratam da informática na educação é possível, também, aprofundar a compreensão da relação existente entre o desenvolvimento do pensamento crítico e o uso das TIC. Recorrendo a Jonassen (2000), quando o autor faz a fundamentação conceitual para utilização do computador como ferramenta cognitiva.

Inspirando-se nas políticas públicas vigentes no país a pesquisa busca reposta para a seguinte questão: Existe uma relação entre o uso das TIC, a formação do pensamento crítico e a pretendida inclusão social, proclamada como um dos pilares básicos da educação brasileira?

Buscando responder à questão proposta, sente-se necessidade, em primeiro lugar, de explicitar o significado da espiral de aprendizagem, concepção que supera a idéia de ciclo na construção do conhecimento com o uso do computador.

Valente (2002) analisa que a construção do conhecimento ocorre num processo relacional do sujeito com outros sujeitos e/ou objetos. Dessa interação, podem decorrer mudanças conceituais, que partem de abstrações empíricas e chegam à reconstrução ou reorganização de conhecimentos, enquanto ato mental reflexivo.

Em sua discussão, demonstra que o processo em análise sugere uma certa ordem e idéia de repetição em contraposição à idéia de constante aprimoramento e crescimento contínuo do conhecimento, mais coerente com uma idéia de espiral, ou seja, idéia que explica melhor como o aprendiz processa a construção do conhecimento, na interação com o computador.

Isso porque, ainda acompanhando o raciocínio do autor em questão, em cada ação do ciclo descrição - execução - reflexão - depuração, níveis mais sofisticados de conhecimentos são incorporados, em decorrência da reflexão realizada pelo aprendiz, ao interagir com o computador.

Nessa medida, considera-se que não se pode falar de uma certa ordem, nem reduzir essas ações à idéia de repetição que o ciclo encerra, porque a reflexão de cada aprendiz, em momentos e/ou situações diferentes, envolve conceitos, percepções, estratégias por ele utilizadas que mudam e são revisitadas a cada momento e situações diferentes.

Daí, sob um dado aspecto, a importância da interação aprendiz - computador, em termos de desenvolvimento do pensamento crítico. As decisões tomadas pelo aprendiz durante esse processo não são lineares. Desencadeiam questionamentos, dúvidas, experimentações... busca de resposta para os problemas que se the apresentam, gerando pesquisa e reflexão.

Em função das contingências aí presentes, mais do que apropriar-se de saberes produzidos e acumulados, ao longo da história da humanidade, o aprendiz é desafiado a pensar, criar, encontrar soluções. Estabelece-se, assim, um processo de pensar e aprender, mais amplo e complexo, que justifica o significado dado pelo autor à espiral de aprendizagem. 
Quando isso se dá no nível da ação coletiva, ainda que virtual, acontece um processo efetivo de auto-regulação da aprendizagem através da reflexão sobre a própria experiência, favorecendo perceber e analisar os percalços, avanços e resultados do sujeito que aprende. Trata-se, de uma das formas mais concretas (a da aprendizagem à distância) de se referir ao aluno como sujeito da aprendizagem.

\title{
Para Prado (1996)
}

\begin{abstract}
o ponto central é que essa formação está fundamentada na reflexão sobre a própria experiência que o aprendiz realiza no seu ambiente de trabalho. Essa formação baseada em uma prática cria mecanismos de reflexão que acontecem em diferentes níveis, os quais podem ser explicados a partir da recontextualização do ciclo que ocorre na interação aprendiz - computador.
\end{abstract}

Como o uso do computador no processo da aprendizagem surgiu e foi enfatizado pelo viés cognitivo, essa postura que considera o sujeito-aprendiz na sua complexidade - ser que pensa, age, sente - significa um avanço na relação homem-ferramenta de trabalho.

Diz respeito à inteireza do ser que conhece, mas o faz percebendo as próprias competências e limites, descobrindo na interação com o professor, e/ou companheiros de aprendizagem, o sentido da cooperação, a dimensão social e afetiva presentes nesse processo. É necessário aprofundar estudos que permitam compreender e visualizar melhor a dimensão emocional que permeia esse processo, não apenas reconhecendo o papel da autoestima na aprendizagem individual, mas, também, a contribuição que isso pode trazer para o avanço do conhecimento, em benefício da sociedade como um todo.

Tem-se que essa abordagem resulta num nível de consciência que favorece assumir responsabilidade pela construção de maneiras próprias de se solucionar problemas; ao contrário dos posicionamentos ainda resistentes ao uso do computador para aprender, analisando-se pelo aspecto até aqui tratado, a essa abordagem crítica é possível corresponder o que se defende denominar compromisso emancipatório das TICs com o sujeito aprendiz.

Jonassen (2000) trata com bastante objetividade a questão contida nesse estudo: defende como principal razão para a utilização dos computadores como ferramentas cognitivas o fato de que os mesmos envolvem, necessariamente, os alunos no pensamento crítico. $O$ autor considera os computadores como ferramentas para pensar, como formas de representação do conhecer, que aí estão para os sujeitos aprenderem: dão acesso à informação, abrem espaço para que sejam capazes de discutir e interpretar a informação, organizar e representar o conhecimento pessoal.

Esse mesmo autor ainda defende que o computador, enquanto ferramenta cognitiva está a serviço da construção do conhecimento, provocando a capacidade de conhecer, numa abordagem construtivista, por conseqüência, significativa para o sujeito cognoscente. Dessa forma, argumenta que o aluno, como sujeito ativo, interpreta o mundo exterior, reflete sobre suas interpretações e, não apenas, armazena interpretações feitas pelo professor. Nesta perspectiva, por sua dimensão reflexiva, o aprendiz conduz o próprio processo de cognição, deliberando sobre os rumos que deseja, pode ou deve imprimir a ele, comprometendo-se com a ação de aprender, com todo o processo de construção do próprio saber.

O autor citado assume uma perspectiva construtivista na construção do conhecimento e, ao fazê-lo, fundamenta, conceitualmente, as ferramentas cognitivas como sendo "ferramentas informáticas adaptadas ou desenvolvidas para funcionarem como parceiros 
intelectuais do aluno, de modo a estimular e facilitar o pensamento crítico e a aprendizagem de ordem superior" (JONASSEN, 2000)

Ao tratar da questão com esse enfoque, põe em evidência o fato de que os alunos são levados a pensar profundamente sobre o conteúdo em estudo, tornando-os aptos a decidir, mas, sobretudo, a propor soluções inovadoras.

Exercer o pensamento crítico torna-se o objetivo das ferramentas cognitivas; indo além dos modelos tradicionais, o pensamento crítico e concebido por Jonassen (2000) como pensamento reflexivo que viabilize idéias originais, que não se limitam à lógica factual das concepções tradicionais.

Propõe, então, que se trabalhe com um Modelo de Pensamento Complexo (JONASSEN, 2000, p. 38-45), baseado na superação de competências separadas, ou seja, num sistema interativo: um pensamento elementar de conteúdo que se articula com uma reorganização do conhecimento (pensamento crítico) e que, num movimento de síntese, é capaz de gerar conhecimento novo (pensamento criativo).

No ponto de partida do pensamento criativo está o acesso e a interpretação da informação, além da sua análise e avaliação. Uma vez ocorrida essa interação entre o conhecimento aceite e o conhecimento crítico, o pensamento criativo exige ir além, fundandose em três componentes principais: sintetizar, imaginar e elaborar.

As ferramentas cognitivas são, conceitualmente, os recursos usados para representar a compreensão que permite fomentar tais competências, indispensáveis ao pensamento crítico e ao pensamento criativo.

Retoma-se, aqui, a pergunta que norteou o presente estudo: Existe uma relação entre o uso das TIC, a formação do pensamento crítico e a pretendida inclusão social, política pública declarada da educação brasileira?

Ao encaminhar uma resposta para a questão inicialmente posta, parte-se do pressuposto de que políticas públicas inclusivas precisam ser integradas, para não caírem numa abordagem fragmentada sem efetividade, ou seja, que não leva a resultados.

Esse posicionamento é motivado pelo fato de que a problemática da inclusão/exclusão é complexa e não se resolve, de maneira simplista com ações pontuais como, por exemplo, quando se fala da inclusão digital como garantia de inserção e de ascensão no mercado de trabalho.

Para se discutir esse aspecto, é necessário remetê-lo para o campo da cidadania; Canclini (2005, p.103) afirma que

\footnotetext{
Conquista-se cidadania não só obtendo respeito às diferenças, mas contando com os mínimos competitivos em relação a cada um dos recursos capacitadores para participar da sociedade: trabalho, saúde, poder de compra e os outros direitos sócio-econômicos, junto com a "cesta" educativa, informacional, de conhecimentos, ou seja, as capacidades que podem ser usadas para conseguir melhor trabalho e maiores rendas.
}

No entanto, a inclusão como condição imprescindível de cidadania não pode ser considerada de maneira reducionista, somente pelo viés da alfabetização / inclusão digital, como o senso comum tem abordado.

No desenvolvimento desse estudo, a ênfase ao pensamento crítico pôs em evidência a dimensão defendida, ao discutir o uso das TIC como fator de inclusão. Não se trata de absolutizar o acesso à informação como condição de participação; mais importante que isso seria desenvolver competências capazes de fazer de cada cidadão o sujeito ativo da 
construção do seu destino pessoal, capaz de analisar, avaliar, decidir, mas, sobretudo, de definir soluções para os problemas que enfrenta no seu cotidiano. E é nesse sentido, que o uso das TIC, nos termos defendidos nesse estudo, responde às políticas públicas inclusivas, já que não se reduzem a instrumentalizar trabalhadores para o mercado de trabalho.

A experiência que motivou a pesquisa demonstrou que a autonomia e resistência cultural estão presentes no cenário da formação de docentes indígenas e desta forma um projeto de inclusão social não poderia deixar de contemplar uma reflexão sobre a própria experiência que o professor vivencia no seu ambiente de trabalho, possibilitando a aquisição das diferentes linguagens possibilitadas pela tecnologia, em especial o uso do computador, de forma contextualizada e crítica.

\section{Referências}

APPLE, M. W. Ideologia e currículo. Tradução Vinicius Figueira. 3. ed. Porto Alegre: Artmed, 2006.

BURBULES, N. C.; TORRES, C. A. (Org.). Globalização e educação, São Paulo: Artmed, 2004.

FELDMANN, M. G. Formação de professores e o ensino da arte na escola brasileira. São Paulo. Revista PUCVIVA ano $6 \mathrm{n}^{\circ} 222$ out./dez/2004.

FORQUIN, J. C. Escola e Cultura: as bases sociais e epistemológicas do conhecimento escolar: Porto Alegre: Artes Médicas, 1987.

GARCIA CANCLINI, N. Diferentes, desiguais e desconectados: mapas da interculturalidade. Trad. Luís Sérgio Henriques. RJ: Ed. UFRJ, 2005.

GRAMSCI, A. Os intelectuais e a organização da cultura. Rio de Janeiro: Civilização Brasileira, 1978.

JONASSEN, D. H. Computadores, ferramentas cognitivas: Desenvolver o pensamento crítico nas escolas. Portugal: Porto Editora, 2000.

PRADO, M. E. B. B. O uso do computador na formação do professor: um enfoque reflexivo da prática pedagógica. Campinas: UNICAMP/Faculdade de Educação. (Dissertação de Mestrado).

SACRISTÁN, G. A educação que ainda é possível - ensaios sobre uma cultura para a educação. Porto Alegre: Artmed, 2007.

O currículo: uma reflexão sobre a prática. Tradução Ernani F. da F. Rosa. 3. ed. Porto Alegre: Artmed. 2000.

Poderes instáveis em educação. Porto Alegre: Artes Médicas. 1999.

VALENTE, J. A. A espiral da aprendizagem e as tecnologias da informação e comunicação: repensando conceitos In: JOLY, M. C. A tecnologia no ensino: implicações para a aprendizagem. São Paulo: Casa do Psicólogo, 2002. 


\title{
AS POLÍTICAS PÚBLICAS DE EDUCAÇÃO DO CAMPO EM RONDÔNIA: INTERVENÇÃO ESTATAL A SERVIÇO DO IMPERIALISMO
}

\author{
Marilsa Miranda de Souza
}

\section{Introdução}

A pretensão deste artigo é analisar as relações de dependência do Estado brasileiro frente às estratégias de expansão do capitalismo em sua fase superior e analisar as políticas públicas educacionais para a educação do campo financiadas pelos organismos internacionais em Rondônia. Essas políticas se articulam em torno de um objetivo comum: controlar o território amazônico e apoderar-se de suas riquezas.

No caso do campo rondoniense a situação é grave. A frente agropecuária e o agronegócio avançam promovendo uma situação caótica de mercantilização e destruição da natureza por meio de políticas imperialistas gestadas e financiadas pelas agências de regulação multilaterais (Organização Mundial do Comércio - OMC, Fundo Monetário Internacional - FMI, Banco Mundial, etc.) que afastam a cada dia a intervenção do Estado Nacional e consolidam a política norte americana de controle direto do território amazônico (CAMELY, 2006).

O objetivo central das políticas públicas financiadas pelos referidos organismos na América Latina é de expandir o capitalismo a partir de uma nova forma de acumulação e divisão internacional do trabalho produzida pela profunda crise do capitalismo atual e assegurar a hegemonia norte americana sobre as semicolônias inserindo-as na sociedade do consumo.

A educação articula-se a essas políticas públicas de controle de território, por isso o Banco Mundial preocupa-se especialmente com a educação do campo na Amazônia, financiando projetos e programas que estimulam os camponeses/as a deixarem o campo ou inserirem-se nos novos modelos produtivos impostos pelo mercado.

\section{A ação do imperialismo no campo e a destruição da agricultura camponesa}

A ação do imperialismo em Rondônia remonta a história da Amazônia destacando-se nos ciclos da borracha, do ouro, da cassiterita, dos grandes investimentos agropecuários, dos programas de controle do território e exploração de recursos naturais por meio de programas como SUDAM, PROTERRA, POLONOROESTE, PLANAFLORO, ZEE - Zoneamento Econômico-Ecológico, etc. Nos últimos anos, o capital vem avançando de forma cada vez mais voraz, iniciando um novo ciclo de exploração, dessa vez sobre os solos da Amazônia, por meio do chamado agronegócio. 
O latifúndio vem se expandindo devido aos processos de mecanização e commodities, chamado pelos capitalistas de $\mathrm{AGRONEGÓCIO}{ }^{36}$, que preferimos chamar de latifúndio de novo tipo, como forma de ressaltar seu verdadeiro caráter: ser um latifúndio. Agronegócio é nome dado à agricultura capitalista. No Brasil o termo é inadequado, pois o que vigora aqui com nome de agronegócio não é uma empresa essencialmente capitalista, mas uma empresa semicapitalista onde vigora as relações semifeudais e um forte vínculo com o imperialismo. Devido ser mais produtivo e empregar novas tecnologias o chamamos de novo tipo, mas não podemos chamá-lo de agronegócio. Agronegócio é uma palavra nova, mas tem origem no sistema de plantation norte americano e refere-se ao modelo de desenvolvimento agropecuário capitalista. É a nova roupagem da agricultura capitalista, para que seja vista como moderna e produtiva. O latifúndio de novo tipo, é antes de tudo uma construção ideológica que tenta transformar a imagem do latifúndio atrasado e semifeudal em latifúndio produtor de riqueza.

O latifúndio de novo tipo significa mais concentração de terra e conseqüentemente sua expansão pelas fronteiras agrícolas com a pecuária e a monocultura da soja, tornando ainda mais aguda as contradições e injustiças sociais. Em essência, o latifúndio de novo tipo significa a perpetuação da grande propriedade latifundiária baseada na exploração de relações semifeudais de produção, por manter relações de semiservidão e outras formas precárias de trabalho. Para camuflar sua face excludente, busca-se a combinação com a agricultura realizada pelos camponeses pobres, como se não houvesse nenhuma contradição nas formas de produzir, e o pior; busca-se a fragmentação de seus sujeitos. Os paupérrimos seriam os camponeses e os mais estruturados economicamente seriam os agricultores familiares. Essa divisão é utilizada pelo Estado para manter uma parte dos camponeses, como aliados da burguesia, de forma que não percebam a desigualdade gerada pelo latifúndio capitalizador da renda da terra.

As ocupações de terra ferem profundamente a lógica do latifúndio de novo tipo. $O$ Estado brasileiro busca de todas as formas conter a efervescência no campo criminalizando o Movimento Camponês e intervindo militarmente. As lutas no campo têm se intensificado porque a reforma agrária de mercado, orientada pelos interesses do capital internacional, (especialmente nos governos de Fernando Henrique Cardoso e Luiz Inácio Lula da Silva) também não passa de um mecanismo para manutenção e fortalecimento do latifúndio. Dentre as políticas recentes de "reforma Agrária", também financiadas pelo Banco Mundial, estão o Banco da Terra e o Projeto de Crédito Fundiário e Combate à Pobreza Rural.

Do ponto de vista ecológico, esse modelo de desenvolvimento do campo representa uma verdadeira tragédia. Os "pacotes tecnológicos" desenvolvidos pela chamada Revolução verde, destinados a maximizar a produção, tentam criar as condições ideais para o cultivo, eliminando os competidores e predadores naturais com agrotóxicos e corrigindo os solos com fertilizantes químicos. O meio ambiente se torna artificial e simplificado, destinado apenas a produzir lucro imediato para satisfazer a gana do capital. Busca-se a homogeneização dessas práticas pela intensiva utilização de máquinas agrícolas, equipamentos pesados, agrotóxicos e

\footnotetext{
${ }^{36}$ O conceito de "agribusiness" foi proposto pela primeira vez em 1957, por Davis e Goldberg, como a soma das operações de produção e distribuição de suprimentos agrícolas, processamentos e distribuição dos produtos agrícolas $e$ itens produzidos a partir deles. Disponível em: http://www.portaldoagronegocio.com.br. Acessado em: 01/10/2009.
} 
fertilizantes, sementes modificadas, etc. Essas práticas causam impactos sócio-ambientais profundos aos ecossistemas simples e complexos: degradam os solos, destroem as águas devastam a floresta, destroem a diversidade genética de plantas e animais e contaminam com agrotóxicos os alimentos que chegam à mesa da população.

O desenvolvimento da agricultura capitalista na forma do latifúndio de novo tipo expressa essencialmente os interesses do capital internacional que subordina a política pública congregando todas as ações governamentais em relação à questão agrária. $\mathrm{Na}$ Amazônia esse processo é evidente. Camely no seu estudo sobre as ONGs do Acre afirma ter o imperialismo norte americano dividido a Amazônia em dois campos.

\begin{abstract}
O imperialismo norte-americano, através de suas agências internacionais dividiu a Amazônia em áreas de produção intensiva de produtos agrícola onde a inversão de capitais norte-americanos e japoneses alcança uma longa faixa que parte do centrooeste do Brasil até a Amazônia Ocidental e espaços destinados à proteção ambiental, grandes áreas de florestas, geralmente controladas por organizações norte-americanas (CAMELY, 2006, p.06).
\end{abstract}

Desta forma fica fácil entender o crescimento vertiginoso do latifúndio de novo tipo em Rondônia e a vigilância norte americana sobre nosso território. A presença dos camponeses e extrativistas, como denuncia Camely, é um empecilho para o domínio da região.

Esse modelo, além de causar fortes danos ambientais, fragmenta e decompõe a agricultura camponesa. Os camponeses são excluídos do campo, não são incorporados pelo mercado urbano e muitas vezes são empurrados para ecossistemas extremamente frágeis, como é o caso dos camponeses migrantes em diversas áreas da Amazônia. O custo desse processo de modernização tem sido alto. Representa maior concentração de terra, maior exclusão social e, sobretudo, intensos danos ambientais, o que não deixa dúvidas de que é um modelo insustentável contra o qual se colocam os camponeses.

\title{
O Banco Mundial e a educação do campo em Rondônia
}

Como apresentamos, a ingerência do Banco Mundial está presente nas políticas de exploração de recursos naturais pelo capital multinacional e no controle geopolítico da região. Mas a principal ação do Banco Mundial no Brasil, diz respeito à educação que de forma abrangente e sistêmica direciona e conduz a passos largos o processo de privatização da educação pública. Quase toda a política educacional atual é fruto de uma influência do Banco Mundial, conforme estudos de Hadad (1998), Tommasi (1996), Rosar (1999), entre outros.

A política educacional ditada pelo Banco Mundial visa formar "capital humano" para atuar num sistema produtivo reestruturado, conforme as novas técnicas de exploração do trabalho.

\begin{abstract}
La capacidad de um país para aplicar la tecnologia moderna a la producción agrícola e industrial depende em gran medida de la calidad de su capital humano (...) La cantidad de adultos de los países em desarrollo com el nível de instrucción necesario para producir, adquirir, adaptar y aplicar las tecnologias modernas a la producción agrícola industrial es peligrosamente baja (BANCO MUNDIAL, 1990, p.12).
\end{abstract}

É aí que entra a educação do campo, pois o Banco Mundial tem uma "preocupação" imensa com o espaço do campo brasileiro pelos vultosos lucros que ele produz às economias hegemônicas. As metas, como expressa o próprio Banco, é de ampliar a utilização das 
tecnologias modernas, ampliar o número de consumidores e disseminar o latifúndio de novo tipo.

\begin{abstract}
La productividad de los agricultores reviste especial importância, dado que gran parte de la fuerza laboral de los países em desarrollo se dedica a la agricultura de subsistencia. Para evaluar los efectos de la educación sobre la producción agrícola, se compara la producción de los agricultores que ham alcanzado distintos níveis de educación (BANCO MUNDIAL, 1990, p.2).
\end{abstract}

Nota-se que o Banco Mundial preocupa-se com a produtividade, com o lucro da agricultura e com a qualificação da força de trabalho. Se a "grande parte da força de trabalho nos países em desenvolvimento se dedica à agricultura de subsistência" é necessário minar e destruir esse tipo de agricultura e garantir o êxodo dos camponeses para a cidade. Quando isso não é possível, pelo menos que estes melhorem seus conhecimentos para adequar-se às novas tecnologias agrícolas e entrar para o mercado consumidor de produtos químicos como os agrotóxicos fertilizantes e sementes transgênicas produzidas por empresas monopolistas como a Mon Santo. Vejamos a clareza com que o Banco expõe seus objetivos em relação à educação dos camponeses:

Los conocimientos de aritmética elemental ayudan a los agricultores a estimar los rendimientos de actividades anteriores y los riesgos de actividades futuras, em tanto que el saber leer y escribir les ayuda a aplicar apropiadamente la tecnología agrícola moderna (por ejemplo, los productos químicos agrícolas, los fertilizantes artificiales y las nuevas variedades de semillas) ya a llevar registros (BANCO MUNDIAL, 1990, p. 4).

Se os outros projetos de "desenvolvimento sustentável" (conceito produzido na esfera do imperialismo norte americano) financiados pelo Mundial na Amazônia visam controle de território, especialmente as áreas de fronteiras, a educação muito pode contribuir nesse processo.

Para garantir seus objetivos, os projetos educacionais financiados pelo referido Banco na década de 1990, o chamado Projeto Nordeste, serviu como um termômetro na implementação de projetos para a área de educação que resultou no Projeto FUNDESCOLA 01 (School Improvement Project FUNDESCOLA 01). Atuando nas regiões Norte e CentroOeste, em 10 estados e 181 municípios, serviu como projeto piloto para a implantação de outras versões: FUNDESCOLA II e III. A intenção do Banco com o FUNDESCOLA é ajudar a "garantir crianças melhor preparadas para participar ativamente, como cidadãos produtivos, de uma sociedade democrática" (BANCO MUNDIAL, 1998, p.02).

O projeto estava pautado em 04 componentes: Fortalecimento da Gestão Escolar, Desenvolvimento de Modelos Pedagógicos, Adequação de Prédios Escolares e Fornecimento de Mobiliário. Podemos dividir as ações do projeto em duas grandes áreas: 1- Programa de apoio à escola e às secretarias de educação (que se divide em duas coordenações, a de Gestão e a de Padrões Mínimos) e 2-Modelos pedagógicos para a formação continuada de professores (que possui a Coordenação de Modelos Pedagógicos), como também suas subdivisões: Programa de apoio à escola e às secretarias de educação; Plano de Desenvolvimento da Escola (PDE); Planejamento Estratégico da Secretaria (PES); Projeto de Adequação dos Prédios Escolares (PAPE); Modelos pedagógicos para a formação continuada de professores; Programa de Apoio a Leitura e Escrita (PRALER); Gestão da Aprendizagem Escolar (GESTAR); Novos Rumos da Avaliação Escolar; Fortalecimento do Trabalho da Equipe Escolar e Escola Ativa. 
Dentre essas ações, o projeto GESTAR, a ESCOLA ATIVA e o Projeto de Adequação dos Prédios Escolares (PAPE) foram os que mais prejudicaram a educação do campo na Amazônia Ocidental, principalmente o Estado de Rondônia. A Escola Ativa se caracteriza como uma "metodologia de ensino destinada às classes multisseriadas da zona rural e das periferias dos centros urbanos" e foi responsável pelo fechamento de muitas escolas do campo, especialmente as escolas multisseriadas que oferecem ensino das séries iniciais.

O processo de destruição das escolas multisseriadas em todo o país iniciou-se em 1990. Para tender as novas orientações do imperialismo em retirar os camponeses do campo para ceder lugar ao latifúndio de novo tipo, o MEC por meio do FUNDESCOLA lança a proposta de centralização ou nucleação das escolas do campo com o argumento de que o nível de aprendizagem dos alunos é inferior nas escolas multisseriadas, que há altos índices de repetência e evasão e má formação dos professores, etc. A UNESCO e o Banco Mundial por meio de pesquisas sobre o desempenho das escolas multisseriadas na África, na Ásia e América Latina chegaram a conclusão que essas escolas são amplamente inferiores aos das seriadas, desta forma, orientam que devem ser fechadas ou organizadas a partir do Programa Escola Ativa.

As escolas multisseriadas foram desativadas e aglutinadas sob a forma de núcleo, ou pólo. Em Rondônia se popularizou com o nome de escola-pólo. O FUNDESCOLA nas ações do Projeto de Adequação dos Prédios Escolares (PAPE) lançou aos municípios a proposta de financiar a construção de escolas-pólo. A maioria dos municípios de Rondônia adotou essa política. Construíram escolas-pólo, fecharam as escolas multisseriadas e desde então as crianças são transportadas a longas distâncias em ônibus precários, também financiados pelo Banco Mundial através dos programas Caminho da Escola e o Programa Nacional de Apoio ao Transporte do Escolar - PNATE.

O transporte escolar passou a fazer parte da agenda educacional e se gasta muito mais com esse elemento de despesa do que com as demandas de cunho pedagógico, formação de professores, melhoria das condições de trabalho, etc. Municípios como Rolim de Moura, Ariquemes e Colorado D'Oeste em Rondônia gastam de seu orçamento mais de um milhão de reais anualmente com transporte escolar, como identificamos em pesquisa realizada no ano de 2008, uma vez que os recursos repassados pelos programas do Banco Mundial não são suficientes.

Com a nucleação das escolas, os alunos são transportados de ônibus, deixando seu espaço de produção, afastando-se de sua realidade. A rotina de convivência camponesa foi alterada e passou a ter uma lógica urbana. Para estudar os filhos dos camponeses devem levantar de madrugada, pois a viagem até a escola é muito longa. As crianças e jovens permanecem um período na escola e, às vezes, quase o mesmo tempo viajando, em péssimos meios de transporte e estradas esburacadas, sem nenhuma segurança. $O$ não atendimento das crianças na comunidade em que vivem é um forte estímulo para que os camponeses abandonem o campo para o latifúndio e a monocultura representada pelo latifúndio de novo tipo. As escolas-pólo funcionam com projetos pedagógicos alheios à realidade e aos interesses dos sujeitos do campo, em muitas delas foram implantadas o projeto GESTAR e ESCOLA ATIVA, que deixou de fazer parte apenas do universo das escolas multisseriadas.

A prática de execução de todos esses programas do FUNDESCOLA materializa-se através de atividades de consultoria, capacitação de formadores e disseminação da proposta na localidade de implantação, com duração de cursos entre 40 e 120 horas, caracterizados 
como capacitação ou retroalimentação em estratégias metodológicas, utilizando material pedagógico que chegam aos professores/as como "pacotes" educacionais, com kit's pedagógicos, livros e Guias de Aprendizagem, que devem ser seguidos rigorosamente para não comprometer sua funcionalidade. Conforme Rosar, "as possíveis intenções implícitas do projeto, quais sejam de apenas 'reproduzir', 'treinar', sem que se amplie a capacidade de reflexão e de produção de novos conhecimentos elaborados coletivamente, numa perspectiva crítica" (ROSAR, 1999, p.170).

A educação dos camponeses sempre foi desprezada. O campo possui os maiores índices de evasão, repetência, distorção idade-série, má qualidade do ensino. O campo é historicamente o lugar da exclusão, pobreza e resistência popular. O Banco Mundial conhece bem este terreno, por isso propôs o projeto Escola Ativa para vários países da América Latina. Começou com a Colômbia em 1980 e estendeu-se para o Brasil, Argentina, Chile, Costa Rica, Equador, Guiana, Guatemala, Honduras, Paraguai e República Dominicana. No Brasil a Escola Ativa foi implantada em 1997 no Norte e no Nordeste, considerados pelo Banco como ZAP - Zonas de Atendimento Prioritário.

Em Rondônia o projeto teve inicio em 1999 com 7 municípios (Porto Velho, Candeias, Itapuã, Nova Mamoré, Campo Novo, Buritis e Cujubim. Em 2000 foi estendido para Ji-Paraná, Ouro Preto D'Oeste, Theobroma, Presidente Médici, Nova União, Urupá, Jarú, Governador Jorge Teixeira, Vale do Paraíso e Mirante da Serra, Segundo informações do relatório 2008 da coordenação da Escola Ativa na SEDUC, nos últimos anos ocorreram expansões internas, o número de escolas aumentou, os municípios de Nova União e Urupá, Ouro Preto D'oeste por exemplo aumentaram em 100\% a Escola Ativa. Em Urupá atinge hoje todas as 28 escolas e Ouro Preto todas as 25 escolas. Com essa expansão interna também o município de Ji-Paraná estendeu o programa em 2008 para todas as suas 97 escolas multisseriadas, capacitou 22 supervisores e diretores e 61 professores. No município de Nova União a Escola Ativa se estendeu a partir de 2008 nas 26 escolas multisseriadas e capacitou cerca de 30 professores na metodologia do programa.

Rondônia possui 52 municípios destes, 32 já desenvolveram a Escola Ativa. Os que não têm mais Escola Ativa é porque não tem mais escolas multisseriadas no campo, ou seja, já fecharam todas. Em 2008 o programa atendeu a 5.097 alunos de $1^{\text {a }}$ a $4^{\mathrm{a}}$ série no campo rondoniense e capacitou 266 professores de 213 escolas.

A proposta pedagógica da Escola Ativa fundamenta-se no escolanovismo e apresentase como um "novo" e redentor modelo. Seu objetivo é superar o ensino tradicional valorizando a participação do aluno como sujeito do processo de aprendizagem, reorientar o papel docente como orientador da aprendizagem e reforçar sua a formação em serviço. Essa proposta fundase nas pedagogias neopragmáticas que visam preparar o aluno para as novas exigências do mercado capitalista que almejam trabalhadores "participativos" "flexíveis", "polivalentes", com "competência" para resolver problemas que envolvam a multifuncionalidades do trabalho no processo de produção e aceite o trabalho precarizado e instável dentro da lógica da qualidade total como objetivo central do capital em garantir a produtividade e o controle das relações de trabalho. Isso está muito claro nas publicações do Banco Mundial a respeito da educação. Utiliza-se de terminologias como "produtos", "insumos", "clientela" na área educacional como se estive tratando de uma empresa, da mesma forma em que solicita como consultores profissionais da área de administração e economia para elaborar ou realizar consultorias em questões educacionais. É uma visão puramente mercadológica. 
O GESTAR é um programa de gestão pedagógica da escola, orientado para a formação continuada de professores do Ensino Fundamental, avaliação diagnóstica e reforço da aprendizagem dos estudantes. Seu objetivo é melhorar o desempenho escolar dos estudantes nas disciplinas de Língua Portuguesa e Matemática. O programa utiliza recursos da educação a distância e atende professores do Ensino Fundamental. Os módulos de formação contêm os conteúdos e exercícios a serem aplicados em sala de aula. De forma tecnicista a formação adestra e conduz os professores/as a modelos previamente elaborados na esfera do próprio Banco Mundial.

O GESTAR e a Escola Ativa são uma junção do tecnicismo e do escolanovismo. Identificamos nos seus módulos que buscam organizar o processo de aquisição de habilidades, atitudes e conhecimentos específicos para que os indivíduos se adaptem ao capitalismo global. Aos professores cabem apenas aplicar os exercícios dos módulos com informações precisas e rápidas. Tudo é mensurável, objetivo. Os professores devem buscar as respostas no final do livro e o aluno deve receber e fixar essas informações.

A formação em Língua Portuguesa e Matemática é uma meta dos organismos internacionais. No documento de Jotiem essa meta está expressa. Os camponeses precisam dominar os rudimentos da matemática e da língua, pois são essenciais para o desenvolvimento dos novos consumidores, de força de trabalho minimamente preparada para operar a tecnologia da mecanização agrícola, do uso de insumos, etc. como já ressaltamos.

A educação da língua, a matemática básica é aplicada como treinamento às classes subalternas do capitalismo (as burguesias continuarão a ter uma educação centrada nos conhecimentos universais, na arte, na literatura, etc.). O aprender a fazer, aprender a aprender, no sentido prático, tecnicista, torna visível à metafísica do materialismo e do idealismo, onde a prática se torna o único critério. É a anti-teoria, a anti-ciência, é o pragmatismo na sua forma pós-moderna.

\section{Por uma educação pública de qualidade como direito de todos os sujeitos do campo}

Em Rondônia, o impacto dessas políticas educacionais na educação do campo é ainda mais grave, pois o campo é formado por um conjunto de povos com uma identidade fundada nas diferenças biológicas, históricas e culturais. Um verdadeiro mosaico de costumes, de valores, de jeitos de ser, de falar, formando essa fantástica diversidade cultural formada por dezenas de povos indígenas, negros, brancos, nativos e migrantes que almejam uma educação realmente científica, voltada à sua realidade.

Investigar as políticas de educação do campo torna-se necessário num contexto de imensas contradições que vem sendo apontadas pelas organizações dos camponeses que reivindicam autonomia para construção de políticas públicas de educação. Há quase um vazio em relação às propostas pedagógicas que tomem o campo como referência; no próprio âmbito das teorias educacionais críticas. Para romper com esse vazio é preciso definir o lugar social que a educação pode ocupar na construção de um projeto de sociedade e o que entendemos por escola do campo. A escola do campo deve assumir uma identidade, um compromisso ético/moral com os participantes de nossas práticas educacionais; comprometida com a intervenção social e com a cultura do povo do campo incorporando as lições da educação popular na vida da escola, no jeito de ensinar e aprender. Deve construir nela o espaço público, não apenas pelo seu caráter estatal; construir coletivamente um currículo que 
expresse o movimento da realidade e processá-lo como conteúdos universais, encarando a escola não apenas como lugar de transmissão de conhecimento, mas como um verdadeiro centro de formação humana, que contemple a relação com o trabalho na terra, com a cultura e os saberes de seus sujeitos.

\section{Conclusão}

A apropriação de terras em toda a Amazônia por corporações estrangeiras teve inicio da década de 60 e coincide com financiamentos, planos de desenvolvimento regional, fortalecimento do latifúndio, entre outras. O controle do território pelo imperialismo norteamericano se apresenta na geopolítica por meio de zoneamentos dirigidos pela SAE (Secretaria de Assuntos Estratégicos) pelo controle de áreas protegidas, etc. São imensas faixas de solo, subsolo e espaço aéreo destinadas a desterritorialização que só poderá ser garantida com a desocupação humana do campo.

Por isso, não há como discutir as políticas públicas educacionais na Amazônia sem discutir as relações de poder do capital sobre seu território por meio do modelo e agricultura vigente, fundada na concentração da propriedade da terra. Os mecanismos de controle ideológico da população amazônica e sua retirada estratégica de áreas de interesse do imperialismo têm sido planejados e executados por meio das políticas educacionais. Essa é uma questão que tem gerado inúmeros debates e possibilidades de pesquisa. É preciso avançar no estudo das políticas educacionais para educação do campo e suas conseqüências para seus sujeitos, pois a realidade demonstra que o grande capital descobriu na educação dos povos do campo da Amazônia um novo canteiro de negócios. O desafio que se coloca hoje para os povos do campo é resistir contra essas políticas e construir uma proposta popular de educação do campo articulada aos processos mais amplos da luta pela transformação social.

\section{Referências}

BANCO MUNDIAL. Avaliação da Assistência do Banco Mundial no País, 1998. Disponível na Internet via www.url:http://bancomundial.org.br. Documento acessado em 13 de outubro de 2009.

BANCO MUNDIAL. EI mejoramiento de la educación primaria em los países em desarrollo: examen de las opciones de política. Documento apresentado na Conferência de Educação para Todos, Bangkok, 5 a 9 de março de 1990.

CAMELY, Nazira Correia. Os agentes do imperialismo na Amazônia Ocidental. Rio de Janeiro: Cebraspo, Boletim 49, 2006.

HADDAD. Sérgio. Os bancos multilaterais e as políticas educacionais no Brasil. In: VIANNA, Jr. A. Estratégias dos bancos multilaterais para o Brasil. Brasília: Instituto de Estudos Sócio-econômicos/Rede Brasil, 1998.

SEDUC - Secretaria Estadual de Educação do Estado de Rondônia. Relatório da Escola Ativa. Porto Velho, 2008.

ROSAR, Maria de Fátima Felix. A dialética entre a concepção e a prática da gestão democrática no âmbito da educação básica no Brasil. Educação e Sociedade, dez. 1999, vol.20, no. 69, p.165-176. ISSN 0101-7330. 
TOMMASI Lívia De; WARDE, Mirian Jorge. HADDAD, Sérgio. (Org.). O Banco Mundial e as políticas educacionais. São Paulo, Cortez/PUC/Ação Educativa, 1996. 


\title{
A PARTICIPAÇÃO DAS MULHERES CAMPONESAS NO MOVIMENTO SOCIAL DO CAMPO: UM ESTUDO NA REGIÃO DO CONE SUL DO ESTADO DE RONDÔNIA ${ }^{37}$
}

\author{
Maria Ivonete Barbosa Tamboril \\ Juracy Machado Pacífico \\ Juliane Oliveira \\ Klésia Regina Gregória Prudente
}

\section{Introdução}

Sabemos que historicamente as mulheres lutam para que seus direitos sejam assegurados e possam exercer plenamente sua cidadania. Apesar dos avanços e das conquistas ainda se faz necessário que as mulheres, no campo e nas cidades, assegurem sua participação na sociedade a fim de fortalecer os espaços conquistados e melhorar as relações de gênero. Dentre as propostas dos movimentos de mulheres no Brasil, a participação das mulheres não só na base do próprio movimento, mas também em suas direções, ou seja, nas tomadas de decisões é uma pauta freqüente. Esta conquista possibilitaria não só o reconhecimento de seu papel, mas também a integração de suas reivindicações. Nesta perspectiva, consideramos relevante analisar a participação das mulheres camponesas nos movimentos social e sindical do campo, bem como sua presença nas instâncias organizativas e deliberativas, nos municípios que compõe a região do Cone Sul em Rondônia, e assim contribuir na reflexão acerca das relações de gênero no interior destes movimentos.

A pesquisa realizada, de abordagem qualitativa, elegeu como fonte dos dados:

Pesquisa Documental: Para este estudo foi considerado documento qualquer registro escrito que pudesse ser usado como fonte de informação, referente aos movimentos - social e sindical - constituídos no campo, relacionados com suas instâncias organizativas e deliberativas seja produção local, regional ou global.

Entrevistas individuais: As entrevistas foram realizadas seguindo algumas das orientações metodológicas de Meihy (2002), que discorre acerca dos procedimentos que devemos adotar ao realizar este tipo de tarefa. Para ele a entrevista é uma das fases do projeto e possui as seguintes etapas: Pré-entrevista; Entrevista e Pós-entrevista. Nesta pesquisa realizamos entrevistas únicas e diretivas com pessoas que participam dos movimentos - social e sindical do campo, a saber: dois dirigentes e três mulheres camponesas.

Grupos Focais: O grupo focal enquanto técnica de coleta de dados em pesquisas qualitativas vem sendo utilizada por pesquisadores e pesquisadoras de diferentes áreas no campo das ciências sociais e humanas, principalmente quando desejam apreender informações

\footnotetext{
${ }^{37}$ Pesquisa financiada pelo CNPq.
} 
resultantes da interação grupal. Gaskell (2002, p. 75) considera como objetivo do grupo focal o de "estimular os participantes a falar e a reagir àquilo que outras pessoas no grupo dizem", sendo uma de suas características centrais, "uma sinergia que emerge da interação social", o que, para ele, significa ser o grupo mais do que a soma das partes. Como esta técnica privilegia "a reflexão expressa através da 'fala' dos participantes, permitindo que eles apresentem, simultaneamente, seus conceitos, impressões e concepções sobre determinado tema", (CRUZ-NETO; MOREIRA; SUCENA, 2002), um bom roteiro de debate é essencial na condução do grupo. Na realização desta tarefa a definição e realização de alguns procedimentos foram fundamentais para sua execução: a escolha dos participantes; o planejamento das sessões (elaboração do roteiro); a escolha do local e a preparação do material; a Transcrição das sessões.

$\mathrm{Na}$ organização do material empírico, optamos pela análise de conteúdo, tendo como principal referência às contribuições de Laurence Bardin (1977/1995). Para a autora, a análise de conteúdo, corresponde a "um conjunto de instrumentos metodológicos cada vez mais sutis em constante aperfeiçoamento, que se aplicam a 'discursos' (conteúdos e continentes) extremamente diversificados". O que é considerado comum a todas estas técnicas é a inferência. (BARDIN, 1977/1995, p. 9). Esta opção nos levou a trabalhar com organização categorial a fim de que pudéssemos realizar nossas inferências em função dos objetivos da pesquisa. Após a preparação do material estudamos cada registro como uma totalidade organizada.

No texto o conteúdo das falas foi identificado apenas como "Entrevista - Homem Camponês, 2007" ou "Entrevista - Mulher Camponesa, 2007". O ano refere-se ao ano da coleta dos dados.

\section{Apresentação e análise dos resultados: o que os dados revelam sobre as organizações}

A pesquisa documental possibilitou identificarmos os dados acerca das associações e ou organizações existentes nos municípios que compõem a região do Cone Sul do estado de Rondônia, área de abrangência geográfica do estudo, a saber:

1. Corumbiara: identificadas 31 organizações, destas 26 são denominadas Associações, 3 são cooperativas, e 2 sindicatos. Neste universo somente uma associação de mulheres. $O$ período de criação destas associações varia entre 1994 e 2007. O ano de criação da Associação das Mulheres da Vitória da União (ASMUVIU) foi 1999. Exceto a ASMUVIU cuja direção e sócias são camponesas, apenas em 5 delas identificamos na composição das direções, mulheres, não mais que uma ou duas.

2. Cerejeiras: registradas 19 Associações formalizadas, destas, apenas treze estavam funcionando. Também identificamos a existência de um Sindicato de Trabalhadores Rurais. O ano de criação destas varia entre 1985 a 2000, estando bem diversificado os anos. Nestas associações não identificamos a presença das mulheres nas direções, sendo apenas percebidas em algumas delas na condição de sócias.

3. Cabixi: a pesquisa apontou a existência de 14 associações, destas somente uma tem atualmente uma mulher em cargos de direção, nas demais a participação até como sócias é bem limitada ainda. Nos registros da EMATER identificamos seis grupos informais de mulheres e três grupos de jovens, além de uma cooperativa. 
4. Chupinguaia: existem 11 associações, em 8 delas todos os dirigentes são homens e apenas 2 tem a participação das mulheres sendo uma e duas respectivamente. $\mathrm{Na}$ associação dos Agricultores e Agricultoras do Novo Plano (AGRINOVA) a direção é composta por mulheres e o estatuto desta associação define que a presidência tem que ser exercida por mulheres. Neste município também encontramos um grupo de mulheres informal.

5. Colorado do Oeste: identificamos a existência de 14 associações em funcionamento, destas, 6 possuem nas direções uma ou duas mulheres em cargos, geralmente o de secretária. Identificamos pelo menos umas 10 consideradas desativadas e 6 cooperativas, 1 grupo de jovem e 1 de mulheres informal e 1 Sindicato de Trabalhadores Rurais.

6. Vilhena: confirmamos a existência de 19 associações. Nestas, não foram identificadas à presença das mulheres nas direções nos cargos de presidente, vice ou tesoureiro. Destes cargos, $100 \%$ são preenchidos por homens, as mulheres quando muito apareciam nas atas de registros de composição era no máximo em cargos de secretária. Neste município existe 1 Sindicato de Trabalhadores Rurais, também sem representatividade feminina.

Além destas associações, encontramos ainda uma presença muito forte do Movimento de Pequenos Agricultores (MPA) na região, sendo predominante nos municípios de Colorado do Oeste, Cabixi e Cerejeiras.

Analisando os dados mencionados é possível afirmar que a presença de mulheres camponesas nas direções das associações ou dos sindicatos de trabalhadores rurais na área de abrangência do estudo é imperceptível, sendo mais gritante no município de Vilhena, onde a ausência das mulheres em cargos de direção é inexistente.

\section{O que pensam os sujeitos da pesquisa sobre a participação das mulheres nos movimentos social e sindical no campo}

\section{Participação}

Segundo dirigentes a participação das mulheres tanto nos movimentos quanto em suas direções ou instâncias deliberativas ainda é extremamente precária e pouco representativa, apesar dos esforços do próprio movimento para ampliar esta representatividade. Embora valorizem a participação feminina, as mulheres também reconhecem a pouca participação delas e do papel quase sempre de ouvinte dentro da organização. Em relação à participação das mulheres na direção do MPA, identificamos algumas ocupando cargos na coordenação estadual ou regional, no entanto a representação na direção geral do movimento ainda é desigual. Os aspectos mencionados podem ser observados nas afirmações:

Nessas associações praticamente só participa os produtores, a participação de mulheres é muito pouco. (Entrevista - Mulher Camponesa, 2007).

Eu vejo essa questão, ela é de super importância, mas vejo uma timidez muito grande das mulheres. As mulheres ainda estão muito como ouvinte na organização, no movimento. (Entrevista - Mulher Camponesa, 2007).

Eu acho que elas têm medo de correr atrás da luta, de buscar a realidade do nosso povo, do nosso meio ali [...] eu acho assim que as nossas raízes está ficando oculta, coberta, às vezes a gente que mora no sítio tem vergonha de falar que é um sitiante ou falar que é uma roceira. Muitas mulheres eu acho que o medo delas não é tanto, assim por causa, no nosso grupo lá, não é porque os homens não quer que elas participe, eles até dão força, eles fala assim que tem reunião tem que ir, elas mesmo que não quer ir. (Entrevista - Mulher Camponesa, 2007). 
No MPA, são mais homens do que mulheres, porque a questão é que a mulher não pode estar na direção por ela simplesmente ser mulher, a gente entende o processo de formação das companheiras, no sentido que ela possa se sentir bem no debate e ajudar a construir ainda e ainda prevalecer. O número masculino ainda é maior, se dentro do movimento se discute em $50 \%$ homens, $50 \%$ mulher, uma metade. Aí se discute no grupo, vamos colocar mulher, aí a mulher vai representar o município, mas chega lá só o homem que fala, porque ela ainda encontra essa dificuldade, de sair naquele espaço, discutir também, tem essa questão, que a mulher não pode ficar naquele espaço simplesmente pra estar. Ela tem que estar no espaço, mas ela tem que ser protagonista desse espaço. (Entrevista - Mulher Camponesa, 2007).

\section{Divisão do trabalho: na roça e em casa}

Para muitas mulheres a discussão sobre divisão do trabalho doméstico reproduz ainda as desigualdades entre homens e mulheres, por meio da repetição de práticas seculares onde a responsabilidade de cuidar da casa, dos filhos e do marido são atribuições da esposamulher. A estas tarefas foram se acumulando as de ajudar ao marido a produzir o sustento da família, ou seja, para elas se antes o trabalho era mais o doméstico agora também tem o da roça. Nos relatos das mulheres mais jovens a colaboração nas tarefas da roça e da casa está mais dividida entre elas e os parceiros. Atribuem a isto as mudanças introduzidas nas relações em casa, demonstram ainda certa percepção de que transformações vêm ocorrendo nos atuais relacionamentos e percebem bem isso de uma geração para outra.

[...] as mulheres, elas tem um trabalho em casa, mas também na roça, [...] Houve um tempo em que as mulheres criavam os filhos e cuidava da casa. Agora elas fazem as mesmas coisas que é parir, cuidar dos meninos, da casa, lavar, passar e também cuidar da roça. No geral, os homens não ajuda, [...] quando chega em casa o homem toma banho e vai pra rede e ela se vira. (Entrevista - Mulher Camponesa, 2007).

É assim, eu trabalho na roça, plantando café aí chego em casa, ele se lava e vai deitar na rede e eu vou fazer almoço, varrer casa, lavar roupa não mão, porque não tenho energia, na mão, tenho cinqüenta anos, nunca veio energia pra minha casa. Por isso eu estou na luta, pra ver se melhora, porque é muito sofrido, então o marido vai deitar tranqüilo e eu vou fazer comida, [...]Daí eu fico cansada, chego cansada, vou fazer comida, varrer a casa, lavar a roupa, tratar das coisas, os porcos sem água, água pras galinhas, essas coisas faço só, quando volta pra roça, volta os dois de novo. (Entrevista - Mulher Camponesa, 2007).

[...], por exemplo, a minha mãe vai fazer o serviço da roça, meu pai faz o serviço da roça, no entanto na hora do serviço doméstico enquanto meu pai descansa é minha mãe que faz todo o serviço, isso é claro, em minha casa. (Entrevista - Mulher Camponesa, 2007).

[...] quando chegava em casa eu ia lavar vasilha, fazer janta ele ia tratar de porco, molhar horta, minha lata de flor, sempre a gente, se os meninos estavam sujos ele pegava levava pro banheiro, dava banho, então a gente tinha parceria em tudo.Mas eu nunca fui essa mulher de ficar acomodada. (Entrevista - Mulher Camponesa, 2007).

[...] quando eu vou pra roça, quando chego em casa, meu marido ajuda em tudo, se tem a criança pra dar banho ele dá banho, se vai fazer janta ele faz tudo que eu peço pra ele fazer ele faz. Então, não espera um pelo outro. (Entrevista - Mulher Camponesa, 2007).

\section{Geração de renda}

Muitas mulheres contribuem significativamente na geração de renda, produzindo o sustento da família, o que acarreta ainda mais os desafios de conciliar as tarefas domésticas com a da roça. Daí a necessidade de estarem também organizadas, participando dos movimentos, prioritariamente sindicalizadas, já que em algumas regiões são elas que tocam a terra e asseguram a produção de alimentos.

[...] eu trabalho é tirando leite lá em casa mesmo, [...] eu levanto todo dia quatro horas mais meu piá e meu marido, [...] nós planta mandioca, planta cana, fazer rapadura, tem muito esterco, mexo com criame de porco, eu tenho uma linha de leite em meu nome, laticínio Multibom, eu tenho uma camionete que puxa o leite, eu tenho uma liderança de 
produtor que se eu fazer uma reunião lá em casa que passa convite pra eles, vai tudo te ouvir, lá no meu terreiro, [...].(Entrevista - Mulher Camponesa, 2007).

[...] hoje aqui em Corumbiara quem vive na terra pequena igual eu vivo tem três ou quatro alqueires de terra eu tenho e que me ralar, tenho que vender as coisas, eu faço feira, eu faço as coisas de casa e eu vou vender. Pra gente conseguir tirar um sustento ali, porque aqui não ta fácil não em cima de terra pequena. Então, mulheres que os maridos tem a terra pequena, eles prefere ir pra fazenda e deixar a terra só por conta das esposas. [...]. (Entrevista - Mulher Camponesa, 2007).

[...] ela é filiada, o esposo não é, "eu acho que vou filiar ao sindicato, porque eu vivo disso, é o que eu sei fazer é roçar meu pastinho" a terra dela é dois alqueires, "tirar leite da minha vaca de manhã, ferver pros meus filhos tomar, plantar mandioca pra não precisar buscar do vizinho, plantar uma banana pra não precisar comprar no mercado. Vim do mercado só arroz e feijão" [...]. (Entrevista - Mulher Camponesa, 2007).

\title{
Relações de gênero
}

De acordo com as mulheres participantes do estudo, os maridos ou os companheiros com que elas convivem quando se trata de assegurar que elas participem em pé de igualdade dos movimentos, muitos ainda resistem. Todavia, percebem que as coisas estão mudando e novas relações entre homens e mulheres se construindo. Os homens também demonstraram percepção acerca do assunto, conforme relatos abaixo:

\begin{abstract}
Meu marido até disse que eu posso ir, mas em casa ele diz pra mim não ir! (Entrevista - Mulher Camponesa, 2007).

Também mostrar que agente é capaz. Nós somos mulheres e se diz que é sexo frágil, que não tem nada disso, mas também mostrar que tem capacidade de lutar, não só os homens e a mulher também querer mudar este tipo de vida que é tão opressora, é através de luta. Se ela ficar de braços cruzados ela não vai conseguir mudar nada. Porque quem mais sofre é a mulher, não tem energia é a mulher, não tem uma casa, é a mulher, o homem já é mais tranqüilo.

Não podia perguntar o que passou na reunião, ficava com ele mesmo. Hoje não, hoje é diferente. (Entrevista - Mulher Camponesa, 2007).

Eu tenho a sensação que as mulheres, por exemplo, minha mãe era mais obediente do que eu [...]. [...] da minha mãe pra mim, convivência dela com o meu pai é bem diferente de mim com o meu marido, [...] quando chegava um homem na casa a mulher não saia da cozinha nem na sala receber o homem, elas ficavam sempre mais distante. Hoje tanto faz o homem tando em casa ou não a gente recebe, com respeito, não tem nada a ver, [...].(Entrevista - Mulher Camponesa, 2007).
\end{abstract}

\section{Formação política}

O grupo revelou reconhecer que para ampliar a participação das mulheres é necessário investir mais em formação, o que elas traduzem dizendo que falta muito esclarecimento. Apesar disso, os grupos de base do MPA apontaram maior preocupação com a discussão de gênero e de acordo com seus militantes já iniciaram estes debates nas reuniões dos grupos, além de estudos de materiais referentes a esta temática.

Para melhorar a participação das mulheres, é preciso investir mais na formação. (Entrevista - Homem Camponês, 2007).

[...] a porta de conhecimento é isso que falta, as mulheradas não tem conhecimento das atividades delas. E então eu acho que pra nós pegar mais conhecimento a mulherada dentro do movimento do sindicato tem que ser feito trabalho de esclarecimento pra elas, [...] falta muito esclarecimento, tem que ser feito um trabalho pra esclarecer pra mulherada. (Entrevista - Mulher Camponesa, 2007).

É discutida a relação de gênero, [...] hoje a nossa maior dificuldade com o grupo de família, quando eles se reúne, é de no mês, uma hora, duas horas, o tempo são restrito pra discutir essas questões e nós sentimos dificuldade que nós não temos questão específica pra discutir com as mulheres, não tem companheira pra iniciar, dirigir, discutir, que é totalmente diferente quando nós vamos fazer um encontro com mulheres que vai os homens dirigindo, a gente encontra dificuldade de abertura de debate quando vai as mulheres, tem essa dificuldade, é, a gente tem dado iniciativa ao discutir a relação de gênero, nós não conseguimos mudar o objetivo do grupo de base se não mudar a questão de gênero. (Entrevista - Homem Camponês, 2007). 


\section{Dificuldades}

As dificuldades para participar dos movimentos e mais ainda, para assumirem cargos de direção estão ligadas a idéia de que são pouco capazes já que tais funções exigem muito conhecimento e se convencem da superioridade masculina, muitas vezes legitimando-a. Além disso, o acúmulo de tarefas seja em casa ou na roça, acrescido da desigualdade entre a repartição destas tarefas, faz com que elas se distanciem cada vez mais dos espaços de liderança. Outra dificuldade apontada é que as mulheres acreditam pouco em suas capacidades, parece não acreditarem muito em si mesmas, o que leva a não assumirem cargos de direção, acrescida esta idéia de que muitos homens ainda sustentam a tese de que as mulheres não precisam participar dos movimentos, seja por desconfiança em relação à parceira ou porque a presença feminina ainda é muito irrisória o que as inibe.

É difícil participar porque a gente tem a casa pra cuidar e tem também a dificuldade que nem é sempre que o marido é de acordo que a gente possa participar de todas as coisas, não é mesmo? Que nem nesse encontro, eles [referindo-se aos maridos] não fica contente da gente vim, de jeito nenhum, ninguém fica. (Entrevista - Mulher Camponesa, 2007).

Têm muitas que não vão na reunião e a gente sabe que é o marido que não quer que ela vá, que não leva, porque eles vão e elas não aparecem, então por quê? (Entrevista - Mulher Camponesa, 2007).

[...] nós era assim: a gente só ia pra roça, pra casa, cuidar de casa, na igreja aos domingos e não se participava de nada. [...] é longe um sítio do outro, muito longe. Que nem eu, aonde eu participo da reunião é $6 \mathrm{~km}$ longe de onde eu moro, o dia que tem que ir pra reunião, vou de bicicleta que meu marido me leva na garupa que eu nem sei andar de bicicleta [...] e muitas vezes eu fui até a pé.

[...] os homens conversa entre si, geralmente os homens fala mais nas reuniões porque eles estão sempre assim na reunião de coordenador, coordenador sempre está lá nosso grupo tem dois coordenadores homens que tem, tinha uma secretária, ela desistiu porque acho que ela não gostou de levar isso. (Entrevista - Mulher Camponesa, 2007).

Eu acho que eles acha que as decisões deles são mais importante, eu acho que eles pode decidir as coisas com mais firmeza, mulher já tem que conversar com eles, então eles já acham melhor deixar nós assim, meio por baixo. (Entrevista - Mulher Camponesa, 2007).

Eu vejo assim, parece que elas não tão acreditando nelas próprias [...] porque elas têm capacidade de assumir uma direção de um sindicato ou de tá na frente de um movimento [...] e exercer qualquer tipo de atividade [...].(Entrevista - Mulher Camponesa, 2007).

[...] a gente sente uma certa discriminação, mas na realidade os produtores não gosta de levaram suas esposas para participarem e a gente convida, inclusive a gente tem uma associadas, sempre convida a participar junto com as esposas e crianças nessas reuniões, mas infelizmente não vão, vão os maridos. (Entrevista - Mulher Camponesa, 2007).

\section{Avanços e conquistas}

$\mathrm{Na}$ opinião das participantes da pesquisa a trajetória do movimento registra avanços e conquistas das mulheres nas organizações e nos movimentos, e para elas representa uma enorme conquista. Apesar da carência das mulheres nas direções, é reconhecido o crescimento da sua presença na base dos movimentos.

Este espaço a gente conquistou, as mulheres conquistou! Mas eu vejo que neste sentido a participação das mulheres é de super importância, não é possível construir liberdade com a mulher dentro de casa, é possível que haja uma atividade de equipe, um conhecimento onde os dois possam ajudar conjuntamente é neste sentido que a gente trabalha a questão de grupo de base. (Entrevista - Mulher Camponesa, 2007). Quando [...] fala, na verdade o que tem acontecido é um espaço de conquista das mulheres, os homens ainda precisam esperar muito ideologicamente para compreender que as mulheres têm uma tarefa fundamental dentro da luta. (Entrevista - Mulher Camponesa, 2007). 
Agora assim, na base organizada do movimento nos tem bastante participação das mulheres [...] agora como função dentro na direção do sindicato é diferente [...] então na base do movimento nos tem a participação até boa das mulheres... (Entrevista Mulher Camponesa, 2007).

[...] eu acho importante. Porque antes, as mulheres sempre eram deixadas um pouquinho de lado e hoje eu creio que até os homens perceberam que as mulheres pensam coisas boas, tem coisas boas travada na mente. [...] pela lei o estatuto já força certa porcentagem e são obrigados, [...] então eu acho que é um privilégio que a mulherada tá tendo delas serem obrigadas a participar que os homens não conseguem fazer nada sem essa porcentagem feminina no grupo deles e creio que é importante que a gente às vezes dentro da casa da gente só fica pensando em enxada por que os lavradores só pensam nisso. (Entrevista - Mulher Camponesa, 2007).

Embora as categorias apresentadas abordem temáticas diferenciadas elas apontam para uma convergência relacionada às relações de gênero e a manifestação do poder no âmbito do público ou do privado. A suposta superioridade masculina está presente seja nas funções "naturais" das mulheres camponesas que são as de parir, cuidar da cria, alimentá-la ou no prolongamento destas funções em relação aos maridos, a casa e a roça.

\section{Comentários e considerações}

A execução do Projeto de Pesquisa "Mulheres Camponesas nos movimentos social e sindical no campo" significou para nós, pesquisadoras e alunas envolvidas na proposta, um período extremamente proveitoso e rico para nossa formação pessoal e intelectual. Neste percurso foi possível um estudo mais aprofundado acerca da história das mulheres e das relações de gênero, além de conhecermos mais de perto a realidade das organizações do campo, pois o olhar criterioso e o rigor científico que somente a realização de uma pesquisa demanda é uma chance singular de trocas e de aprendizagens sobre o objeto a ser compreendido.

Data do início dos anos de 1980, a luta das mulheres trabalhadoras do campo para construírem sua própria organização e representatividade. Segundo elas, a luta pelo Reconhecimento e Valorização das Trabalhadoras Rurais, levou-as a outras batalhas, como a da libertação da mulher, do direito de sindicalizar-se, ter sua própria documentação, assegurar seus direitos previdenciários e assegurar sua participação na política partidária. Nesta trajetória uniram-se a outras mulheres e em 1995, criaram a Articulação Nacional de Mulheres Trabalhadoras Rurais, organização que aglutinou as mulheres de diferentes movimentos dentre eles, o Movimento dos Trabalhadores Rurais Sem Terra - MST, a Pastoral da Juventude Rural - PJR, o Movimento dos Atingidos pelas Barragens - MAB, o Movimento dos Pequenos Agricultores - MPA, a Comissão Pastoral da Terra - CPT e de vários Sindicatos de Trabalhadores Rurais.

Segundo o Movimento de Mulheres Camponesas a categoria - camponês - envolve a unidade produtiva camponesa centrada no núcleo familiar, que se dedica a produção agrícola e artesanal autônoma com o propósito de satisfazer as necessidades de sua família. Além disso, busca identificar a melhor forma de comercializar parte da produção a fim de garantir os recursos necessários para aquisição dos demais bens e serviços de que necessita e que não produz. Neste cenário, a mulher camponesa é definida como aquela que de uma forma ou de outra, produz o alimento e assegura o sustento familiar.

O Movimento de Mulheres Camponesas agrega mulheres das mais diversas profissões ou afazeres cotidianos, mas estreitamente relacionados com as atividades e a vida no campo, 
assim consideradas mulheres camponesas: as agricultoras, meeiras, ribeirinhas, posseiras, bóias-frias, diaristas, arrendatárias, parceiras, extrativistas, quebradeiras de coco, pescadoras artesanais, sem terra, assentadas, acampadas. Sejam elas indígenas, negras, descendentes de europeu representando uma enorme diversidade em nosso país.

Atualmente, no Brasil, o movimento está organizado em dezoito estados incluindo Rondônia e nesta trajetória de pouco mais de vinte anos, acumulou muitas lutas e vitórias podendo ser creditado não só o reconhecimento profissional da mulher trabalhadora rural, mas também o salário maternidade e a aposentadoria aos 55 anos.

Na região do Cone Sul, área de abrangência de nossa pesquisa foi possível além de identificar as organizações sociais existentes refletir acerca da participação das mulheres camponesas tanto nos movimentos existentes quanto nas suas instâncias organizativas e deliberativas.

Os dados nos autorizam a afirmar que na região o movimento mais importante quando se trata de assegurar ou fomentar a participação das mulheres é o MPA, nos demais, tanto associações quanto aos sindicatos de trabalhadores rurais a presença das mulheres é ainda muito insignificante se comparada com a dos homens.

Historicamente as mulheres sempre estiveram em situação de desigualdade e de tão arraigadas tornaram-se naturais as relações desiguais entre homens e mulheres, manifestas através da divisão do trabalho doméstico, do domínio de seus corpos ou da eliminação da presença das mulheres dos espaços de poder e da tomada de decisão. Uma característica das sociedades urbanas é o reconhecimento da crescente participação das mulheres no mercado de trabalho, o que não acontece com as mulheres camponesas, já que suas atividades são consideradas trabalho doméstico, com isso produz-se uma invisibilidade do trabalho da mulher camponesa se comparada a das mulheres urbanas.

Segundo o Relatório sobre a Situação da População Mundial, de 2002, o número de mulheres pobres é superior ao de homens; sua carga horária de trabalho é maior e grande parte de seu tempo é despendido em atividades consideradas "trabalho doméstico", portanto não remuneradas, o que a impede de ter acesso aos bens sociais. De acordo com o Censo Demográfico do IBGE (2000), a população existente no campo é de aproximadamente 32 milhões, o que corresponde a $31 \%$ da população brasileira. Desse universo, $45,5 \%$ são mulheres e, diferentemente daquelas do meio urbano, sua escolaridade é inferior a dos homens.

Apesar dos avanços significativos seja nas conquistas de seus direitos ou relacionados com a própria organização muitos obstáculos ainda precisam ser superados e no caso das mulheres camponesas, a implementação de políticas afirmativas, de geração de renda, acesso a educação e a saúde, é condição fundamental para o exercício da cidadania.

\section{Referências}

BARDIN, Laurence. Análise de conteúdo. Lisboa-Portugal: Edições 70, 1995. CRUZ-NETO, Otávio; MOREIRA, Marcelo Rasga; SUCENA, Luiz Fernando Mazzei. Grupos focais e pesquisa social qualitativa: o debate orientado como técnica de investigação. Disponível em: < http://www.abep.nepo. unicamp.br>. Acesso em: 26 mar. 2003. 
GASKELL, George. Entrevistas individuais e grupais. In: BAUER, Martin W; GASKELL, George. Pesquisa qualitativa com texto, imagem e som: um manual prático. 2. ed. Petrópolis: Vozes, 2002.

MEIHY, José Carlos Sebe Bom. Manual de História Oral. 4. ed. rev. e ampl. São Paulo: Loyola, 2002. 


\title{
O CURSO DE LICENCIATURA INTERCULTURAL NA UNIR: HISTORIOGRAFANDO INTERCULTURALIDADE
}

\author{
Josélia Gomes Neves
}

Depende de mim, depende de nós, escuto um silêncio, ouço uma voz que vem de dentro e enche de luz, toda a nossa tribo, somos todos índios!

Vinícius Cantuária ${ }^{38}$

A Constituição Federal de 1988 amplia o conceito de educação para todas as pessoas (art. 205), levando em conta entre outros aspectos, as demandas dos povos indígenas por acesso à Universidade, no que diz respeito à formação docente. A Lei de Diretrizes e Bases da Educação Nacional (LDB) de Nº 9394 de 1996 referenda as premissas constitucionais (art. 78-79) e o Plano Nacional de Educação (PNE) de 2001 estabelece prazos para o Estado brasileiro alcançar este objetivo (Meta $\mathrm{N}^{\circ}$. 17). Desta forma, as comunidades indígenas uma vez que têm ampliado a educação básica em suas aldeias, agora buscam o acesso às Universidades, entendidas como locais atualmente estratégicos na luta pela autonomia.

Com base nesta política de direitos, no diálogo com os movimentos indígenas e considerando sua pauta formativa, a Fundação Universidade Federal de Rondônia - UNIR, uma instituição de educação superior situada na Amazônia brasileira (que completou em julho de 2009, 27 anos de existência, aprovou na reunião do Conselho Universitário (CONSUN) no âmbito do Programa de Apoio ao Plano de Reestruturação e Expansão das Universidades Federais (REUNI) ${ }^{39}$, no dia 24 de outubro de 2007 o Curso de Licenciatura em Educação Básica Intercultural, destinado à formação de docentes indígenas através da Resolução №. 9 com início definido para julho de 2009 no Campus de Ji-Paraná, Rondônia.

Um gesto que significa, sobretudo, um pequeno passo na direção da viabilização do direito a educação, do respeito às culturas tradicionais, na medida em que com esta ação favorece a permanência de docentes e estudantes indígenas em suas comunidades em um processo permanente de revalorização da Terra Indígena.

Ao propormos o tema Interculturalidade e Universidade: um diálogo possível, apostamos na possibilidade de um encontro a favor dos direitos dos povos da floresta amazônica, tendo em vista a atual situação pós-contato que sugere o estabelecimento de relações pautadas neste esforço de não só reconhecer as diferenças culturais, mas fundamentalmente construir propostas de enfrentamento a diferença na perspectiva de

\footnotetext{
${ }^{38}$ SOMOS todos índios. Vinícius Cantuária; Evandro Mesquita. Disponível em: http://letras.terra.com.br/vinicius-cantuaria/628213/corrigir.php. Acesso em 10/10/2008

${ }^{39}$ RONDÔNIA. UNIR. REUNI. Disponível em: http://www.unir.br/reuni arquivos/UNIR PROJETO REUNI.pdf Acesso 10/10/2008.
} 
aprendizagem coletiva. Quando falamos de Interculturalidade, queremos dizer que trata de um mecanismo com vistas a:

[...] contribuir para superar tanto a atitude de medo quanto a de indiferente tolerância ante o "outro", construindo uma disponibilidade para a leitura positiva da pluralidade social e cultural. Trata-se, na realidade, de um novo ponto de vista baseado no respeito à diferença, que se concretiza no reconhecimento da paridade de direitos. Tal perspectiva configura uma proposta de "educação para a alteridade", aos direitos do outro, à igualdade de dignidade e de oportunidades, uma proposta democrática ampla. (FLEURI, 2003, p. 7).

E a aposta neste diálogo desafiador leva em conta o fato de como estas relações têm se estabelecido ao longo do processo histórico, a origem da Universidade e a trajetória das comunidades indígenas. Os registros nos informam que a UNIR, criada pela Lei $\mathrm{n}^{\circ} .7 .011$ de 8 de junho de 1982 em substituição ao Centro de Ensino Superior de Rondônia, surge "[...] aproveitando o surto de crescimento e desenvolvimento de Rondônia [...]" (SILVA, 1984, p.132) em um contexto de consolidação da colonização em que as forças políticas da época não levaram em conta as características da Amazônia.

Características estas relacionadas à questão ambiental, "[...] os novos povoadores tudo ignoram; vêem a floresta como obstáculo. Seu propósito é tombá-la para convertê-la em pastagens ou em grandes plantios comerciais. [...]' (RIBEIRO, 1995, p. 308) ou as populações tradicionais. No caso das comunidades indígenas de Rondônia do dia para a noite viram seus territórios serem invadidos sem sequer ter tempo para elaborar uma explicação coerente a respeito, conforme ilustra Martins:

\footnotetext{
Posto Indígena Rio Roosevelt-RO, o sertanista Apoena Meireles está dedicado a difícil tarefa de convencer 200 índios Suruí de que - embora cercados por dois mil posseiros vindos do sul, armados e treinados em anos de invasões de terra - eles devem esperar por alguma coisa que mal podem compreender: a FUNAI, o INCRA, a Polícia Federal e sua justiça. (1979, p. 189)
}

Em decorrência disso, podemos listar uma série de outros exemplos para demonstrar esta situação: o caso da implantação do Processo de Assentamento Dirigido (PAD) Burareiro em plena Terra Indígena Uru-eu-Wau-Wau, na região de Ariquemes em 1974 que provocou tensões e conflitos entre colonos e indígenas pelo menos até 2005. Estes desdobramentos negativos para as comunidades indígenas ocorreram porque, entre outros aspectos, quem recebeu o lote pouco tempo depois vendeu para outros e assim sucessivamente, fato corriqueiro no processo de colonização de Rondônia.

De acordo com o Grupo de Trabalho Amazônico (GTA, 2008) órgãos oficiais e não oficiais realizaram em 2003 um Laudo de Vistoria e Avaliação dos recursos naturais e das benfeitorias com vistas a indenizações para os ocupantes, sendo que em 2005 é que foi concedida a liminar de reintegração da posse desta terra aos índios. O documento produzido pelo GTA (2008, p. 48) questiona o significado destas benfeitorias, uma vez que "[...] estas levaram a devastação do patrimônio natural, ou seja: a madeira foi vendida, animais silvestres foram mortos, igarapés foram soterrados, nascentes d'água desapareceram e os indígenas ficaram com o prejuízo. (2008, p. 48).

Este modelo de colonização, caracterizado como assentamento dirigido em função do suposto controle e administração por parte do estado apresentou uma série de distorções além da inserção em parte da Terra Indígena, em outros locais houve a insuficiência de estrutura para que os posseiros pudessem permanecer na terra, daí que: 
A grande massa de pequenos produtores que chegou a Rondônia e teve seus lotes conseguidos pelo INCRA está se extinguindo porque, porque todos na realidade foram usados para 'amansar a selva', visto que estes trabalhadores limpavam imediatamente seus lotes para uso próprio. Em seguida começavam os atritos. Os interesseiros poderosos exerciam pressão para comprar essas áreas já limpas, fazendo com que boa parte dos migrantes-colonos se retirasse: ou eles morriam, pelo 'balaço' ou teriam que ir embora. (PERDIGÃO; BASSÉGIO, 1992, p. 117-118).

Situações como estas, evidenciam que o fato do Estado de Rondônia possuir uma das mais significativas populações indígenas do país - cerca de 11 mil pessoas, 29 comunidades conhecidas, 23 Terras Indígenas que representam um total de $20,82 \%$ da área do estado (GTA, 2008), etnias como os Arara, Gavião, Cinta-Larga, Suruí, Karitiana, Karipuna, Tupari, Makurap, Kaxarari, dentre outros povos, além de 8 grupos isolados, todo este contexto, não garante a sua identificação enquanto estado indígena ou mesmo multicultural e plurilinguístico no imaginário da sociedade local.

No decorrer do processo histórico o que vamos observar é a produção da invisibilidade destas comunidades traduzidas na veiculação da idéia de que a Amazônia era um vazio demográfico, justificativa do Estado para atrair contingentes populacionais para a região com vistas a exploração colonizatória (BECKER,1990). A pouca visibilidade construída sobre os índios, apresentou ao mundo não indígena a concepção de que estes eram selvagens, sem religião ou direitos (LAPLANTINE, 1994). Entregues a própria sorte, enfrentaram sem a proteção do estado brasileiro e muitas vezes, tendo este como adversário, grupos armados ligados aos grandes grileiros de terras na violenta disputa pela ocupação da Amazônia. Neste processo foram quase dizimados nos anos de 1950 a 1980 (RIBEIRO, 1995).

A UNIR por sua vez, na década de 1980, enfatizava sua tarefa formativa oferecendo ao estado de Rondônia quadros principalmente para o funcionalismo público, em sua maioria, cursos de licenciatura tendo em vista a quantidade de pessoas de todos os lugares do Brasil que aqui chegavam. Após quase 20 anos, a partir de 2001, setores da UNIR, primeiro do Campus de Porto Velho e depois do Campus de Ji-Paraná, 2007 iniciam um debate sobre a pertinência de ofertas educacionais para a formação de docentes indígenas, considerando a conclusão de sua formação em nível médio, através do Projeto Açaí.

Na reunião do Departamento de Ciências Humanas e Sociais (DCHS) do Campus de Ji-Paraná, de 30 de março de 2007 foi discutido a solicitação oficial dos docentes indígenas da região central do Estado a respeito da educação superior tendo em vista que em Porto Velho a discussão não estava avançando. O teor do documento, de 29 de março de 2007, dia em que esta decisão foi tomada, afirmava que:

Nós professores indígenas, Gavião e Arara, da representação de Ji-Paraná nos reunimos no dia 29 de março de 2007 para discutirmos sobre o ensino superior indígena aqui na nossa região vimos que a discussão que estava sendo realizada pela comissão instaurada anteriormente e que vinha se reunindo em Porto Velho não estava avançando, resolvemos nos mobilizar aqui no nosso município. Neste primeiro encontro tivemos a presença da professora Josélia da UNIR, da maioria dos professores Arara e Gavião, da equipe da SEDUC, da Coordenação da Padereéhj entre outras pessoas. A professora Josélia nos colocou a disponibilidade da UNIR em apoiar esta iniciativa. Sendo assim, temos a honra de convidá-lo para a segunda reunião que acontecerá no dia 27 de abril na representação de ensino de Ji-Paraná a partir das $8 \mathrm{~h} 30 \mathrm{~min}$. Caso haja modificação na data avisaremos a representação de ensino de cada cidade ou seja, Cacoal, Espigão do Oeste e Alta Floresta. [...]. Esperamos contar com a presença de todos e assim fortalecer o movimento indígena em prol da educação. Atenciosamente, A Comissão. Josias Gavião, José P. Gavião, Ernandes Arara, Marli Peme Arara, Iran Gavião e Sebastião Gavião. 
Um outro diferencial entre as duas discussões, era que enquanto os estudiosos da questão indígena em Porto Velho propunham como encaminhamento a disputa em edital do Programa Pró-Licenciatura Indígena - PROLIND/MEC, para assegurar recursos tendo em vista a instalação e funcionamento do curso para professores e professoras indígenas em caráter finito, a equipe de Ji-Paraná defendia o oferecimento de propostas de formação para docentes indígenas em caráter permanente, que foi possibilitado pelo Decreto $n^{\circ}$. 6.096, de 24 de abril de 2007, que criou o Programa de Apoio a Planos de Reestruturação e Expansão das Universidades Federais (REUNI). Este Programa constitui uma das ações do Plano de Desenvolvimento da Educação (PDE), que tem como objetivo proporcionar às universidades federais condições necessárias para ampliação do acesso e permanência na educação superior.

O que fundamentou a decisão dos pesquisadores e pesquisadoras de Ji-Paraná, ao defenderem uma proposta de curso para os docentes indígenas em caráter permanente, foi o fato de esta proposta significar e assegurar um endereçamento permanente para as comunidades indígenas na Universidade, já que o PROLIND prevê recursos apenas durante a execução do projeto. A história da educação brasileira explicita que há uma descontinuidade nas políticas públicas, pois muitas vezes, estas não se constituem como propostas de estado, institucionalizadas e mais consistentes e, sim como propostas de governo, provisórias e esporádicas. Observamos também outras experiências, de caráter definitivo, principalmente o caso do Núcleo INSIKIRAM da Universidade Federal de Roraima (UFRR).

No âmbito do Programa REUNI, a UNIR através do Departamento de Ciências Humanas e Sociais do Campus de Ji-Paraná, criou o Curso de Licenciatura em Educação Básica Intercultural a partir das demandas apresentadas pelas comunidades indígenas, a formação de seus docentes em nível superior, contribuindo assim para a redução das profundas desigualdades ao possibilitar aos jovens e adultos de diferentes condições socioeconômicas e integrantes de diferentes grupos étnicos o acesso ao ensino superior em Rondônia. Esta decisão em âmbito local foi tomada na reunião de 30 de março de 2007, conforme registra a Ata do DCHS:

\footnotetext{
[...] o chefe do departamento abriu a reunião e pela ordem solicitou aos presentes incluir na pauta a solicitação dos professores indígenas a respeito do acesso ao ensino superior. A plenária concordou por unanimidade. [...] o professor Nelson novamente com a palavra colocou a necessidade de ouvir a solicitação dos docentes indígenas, após, aprovou por unanimidade que o Campus de Ji-Paraná, através do DCHS, encaminhará as providências no sentido de viabilizar a proposta [...].
}

Após a solicitação das comunidades indígenas para criação e implantação do curso de educação superior para habilitação de seus docentes e da decisão do Departamento de Ciências Humanas e Sociais (DCHS) do Campus de Ji-Paraná de encaminhar as providências neste sentido, o próximo passo foi solicitar da direção do referido Campus, a nomeação da Comissão por Portaria para elaboração do Projeto de Educação Superior Indígena em abril de 2007.

A elaboração do Projeto do curso superior foi ocorrendo mediante principalmente os encontros de final de cada mês, ocasião em que os docentes indígenas vinham das aldeias para a cidade de Ji-Paraná para receberem seus pagamentos e fazer compras. É interessante registrar a presença das lideranças nestes momentos como os pajés, caciques, coordenadores de entidades e outras pessoas respeitadas na comunidade. Ali conversávamos sobre o perfil do curso, através de questões orientadoras: quais as necessidades das comunidades, o que 
diz a legislação educacional, que tempo é suficiente para aprendermos e ensinar tudo isso que queremos? Além da equipe da Unir de Ji-Paraná, dos docentes e lideranças indígenas, funcionárias da Representação de Ensino da Secretaria de Estado da Educação (SEDUC) deram suas contribuições na elaboração do Projeto.

No entanto, mesmo em pleno processo de construção, havia um debate já instalado no Campus de Ji-Paraná e as evidências apontavam para outras propostas, onde parecia não haver lugar para o curso de Licenciatura Intercultural. Preocupados com esta questão, os indígenas enviaram mais um documento para o Campus de Ji-Paraná e o DCHS reafirmando seu desejo e direito de estudar, com vistas a assegurar o cumprimento do preceito constitucional, explicitado no artigo 205 da Constituição Federal.

Com o avanço das discussões do REUNI, ficou acordado que cada departamento e Campus deveriam apresentar suas propostas com vistas a sistematização final em Porto Velho. Neste sentido, o memorando de №. 72 de 5 de setembro de 2007, da Direção do Campus de Ji-Paraná (DCJP) para Reitoria, solicitava a inclusão do curso de licenciatura em educação básica intercultural no REUNI com o objetivo de formar professores indígenas para o ensino fundamental e médio nas áreas indígenas e anexa o histórico desta discussão na região central do estado de Rondônia.

No entanto mesmo com a aprovação do DCHS que foi fundamental e com o acompanhamento permanente das comunidades indígenas, aliados e aliadas, faltava ainda uma etapa importante, a aprovação do curso na $2^{a}$ instância local, o Conselho de Campus (CONSEC) formado por representantes de todos os cursos do Campus de Ji-Paraná. Daí que foi necessário uma ampla mobilização que contou principalmente com os movimentos sociais e a sociedade civil organizada de Ji-Paraná, traduzida em muitas ações: ida de grupos indígenas para Porto Velho por ocasião de uma reunião do CONSUN, órgão de representação máxima na Universidade, que não aconteceu em função de manifestação dos estudantes contrários a política do REUNI e também ações locais como diálogos com o Ministério Público e a realização de um abaixo-assinado de apoio a implantação do Curso de Licenciatura em Educação Básica Intercultural contendo a manifestação de várias entidades e segmentos da sociedade local.

No entanto, as dificuldades para aprovação no Campus de Ji-Paraná persistiam, o que atesta talvez a emergência da velha Rondônia colonizadora e anti-indígena, negadora da diferença, conforme registra a imprensa local ${ }^{40}$ :

O encerramento de uma Oficina de Criação para desenvolver o pensamento sobre a mídia, ministrado pela artista plástica Adriana Florense de São Paulo, foi marcado pelo apelo de representantes das etnias indígenas Arara e Gavião pela implantação na Universidade Federal de Rondônia - UNIR Campus de Ji-Paraná do curso de Licenciatura Intercultural em Educação Básica para Docentes Indígenas. Ainda que já exista em estados como o Mato Grosso, Mato Grosso do Sul, Amazonas e Roraima e já ter projeto pronto e aprovado pelo Departamento de Ciências humanas e Sociais do Campus de Ji-Paraná, a implantação do curso tem enfrentado resistências. 'Estamos muito agradecidos pelo engajamento de professores da UNIR com a nossa causa, pois gostaríamos que o curso viesse para Ji-Paraná. Falo isso em nome das comunidades indígenas que pedem socorro para serem ouvidas e atendidas'. Foram com estas palavras que Zacarias Gavião, coordenador da educação escolar indígena e Josias Gavião coordenador da Organização dos Professores Indígenas do Estado de

\footnotetext{
${ }^{40}$ INDÍGENAS reivindicam curso superior. Jornal Folha de Rondônia. $3^{\text {a }}$ feira, 8 de abril de 2008, JiParaná-RO.
} 
Rondônia - OPIRON buscaram sensibilizar representantes da UNIR presentes no encerramento da oficina. O Curso de Licenciatura Intercultural seria a continuidade do Projeto Açaí, que há cerca de três ano habilitou pelo menos 100 professores indígenas ao magistério. Agora, aqueles mesmos índios que participaram do Projeto Açaí reivindicam o curso superior para se tornarem, eles mesmos multiplicadores dentro de suas comunidades.

As aproximações entre a Universidade por meio de seus representantes máximos, Reitor, Vice-Reitora e as comunidades indígenas constituirá um marco significativo na construção de aliados estratégicos. A nosso ver, pode significar uma pequena sinalização da possibilidade de diálogo entre a Universidade e a Interculturalidade. Em agosto de 2007 houve a visita da Vice-Reitora na SEDUC de Ji-Paraná, ocasião em que dialogou com a maioria dos docentes indígenas, afirmando seu compromisso com a instalação da proposta do curso de educação superior para os indígenas. Dando continuidade ao movimento de sensibilização e mobilização, foi marcado posteriormente um encontro entre os professores e professoras indígenas e a Administração Superior da Unir, com a presença do atual Reitor, Pró-Reitor de Pós-Graduação e Pesquisa e a Pró-Reitora de Cultura, Extensão e Assuntos Estudantis em outubro de 2007. Na ocasião o reitor se comprometeu de envidar todos os esforços no sentido de fazer o curso acontecer. As falas abaixo traduzem um pouco do que significou aquele momento:

Estamos na luta há muito tempo por esta conquista na educação, somos 127 professores que se formaram no Projeto Açaí e desde lá a política sobre a formação continuada na universidade já está sendo pensada, tanto com as lideranças quando com as comunidades. Estamos querendo concretizar este sonho. A tendência nossa é que tenhamos este diálogo para entender como funciona a política do ensino superior. Ficamos muito felizes pela sua presença aqui. Queremos conversar e ter um diálogo aberto. Precisamos saber que caminho, temos que trilhar para chegar até a universidade. Se nós não chegar até vocês ninguém vai fazer isso para nós, ninguém melhor do que nós para dialogar com a universidade. Precisamos estabelecer uma parceria transparente.

(Z.K.Gavião.)

Há mais de três anos o Projeto Açaí foi concluído e não tivemos mais formação, este curso habilitou para atuar de $1^{\mathrm{a}}$ a $4^{\mathrm{a}}$ séries, necessitamos de formação diferenciada. Os alunos perguntam: 'por que não passamos de ano que nem o branco', precisamos habilitação para $5^{\mathrm{a}}$ a $8^{\mathrm{a}}$ pois existe uma demanda muito grande na Terra Indígena e temos medo que os alunos saiam da aldeia para estudar fora. Não queremos professor branco, queremos professores indígenas para trabalhar com nossos alunos. Essa luta está a muito tempo, não é de agora, há muito tempo estamos batalhando para isso. É importante a universidade atender essa nossa demanda, os professores indígenas querem se formar em Licenciatura Intercultural.

(J. S. Gavião)

Sou coordenador da Organização Padereéhj que representa 11 etnias e sou coordenador do NEI, Núcleo de Educação Indígena que reúne as entidades parceiras, inclusive as universidades, é uma honra estarmos junto contigo hoje, queremos dar continuidade ao mesmo assunto que tivemos ontem. Estamos nos aproximando da universidade e se aliando aos professores da universidade. Como poderemos ter acesso a universidade depois da formação do Projeto Açaí? Faz três anos que os professores indígenas não têm formação porque faltam projetos para garantir a continuidade da formação destes professores indígenas no estado de Rondônia. A legislação já garante isso, falta só um projeto para colocar em prática esse direito. Queremos colocar este direito em prática de forma justa, através da lei. Para isso queremos ouvir o senhor que é responsável por essa universidade e ouvir como podemos ser parceiros nesta luta. A nossa luta vai continuar para garantir acesso aos professores indígenas e também para os jovens que estão ingressando no ensino superior.

(H. P. Gavião)

Represento o meu povo, etnia Cinta Larga, e quero acrescentar a conversa dos demais, como estamos falando de ensino superior desde quando começou o Projeto Açaí, hoje queremos cursar a universidade onde podemos aprender mais para poder ensinar nossos alunos, nas nossas aldeias é só tem ensino até $4^{a}$ série e isso não é 
suficiente para nós povos indígenas, nossas lideranças cobram a gente e nós não temos como resolver isso. Por isso queremos que vocês que são autoridades nos ajudem queremos aprender como vocês brancos até o doutorado, quem sabe algum dia através desse primeiro passo poderemos ser alguém na vida, nem formação continuada e nem capacitação não temos mais. Como José falou, nossos alunos chegam ao final de nossa aprendizagem, não temos formação suficiente para continuar os estudos dos nossos alunos.

(A. Cinta Larga) Falo em nome dos Arara, nossa grande preocupação com essa discussão é a mesma dos parentes, temos essa expectativa de que podemos chegar na conclusão do nosso ensino, somos cobrados pelas nossas comunidades, criticados, passou da hora de darmos mais um passo para que nossas comunidades possam acreditar mais na gente, se não ingressarmos na universidade a comunidade poderá deixar de acreditar na gente. Queremos isso o mais rápido possível, precisamos da formação de profissionais em diversas áreas, contador, advogado, biólogo, não podemos esperar mais. Queremos nos aliar mais para abrir espaço para as comunidades indígenas do estado de Rondônia e do município de Ji-Paraná, nosso município está mais a frente da política da educação, mais interessado porque todos meses a gente vem aqui para discutir nossos interesses e ouvir nossos parceiros, podemos melhorar nossos conhecimentos, nossa relação, peço que daqui pra frente vocês possam levar essa mensagem aos parceiros de vocês, nós também temos sonhos. (S. Arara)

Muitos são os desdobramentos relativos ao processo de implantação do Curso de Educação Básica Intercultural, tanto para a UNIR como para as comunidades indígenas: a aprovação final do Projeto Pedagógico do Curso no Conselho Superior Acadêmico (CONSEA), a publicação do manual do(a) candidato(a) indígena, a realização do vestibular diferenciado, a contratação dos docentes, a aquisição de equipamentos e construção de espaço físico e a construção da Casa do Estudante Indígena, viabilizada pela Emenda Parlamentar do Gabinete do Deputado Federal Anselmo de Jesus/PT de Rondônia. É preciso continuar apostando neste diálogo.

\section{Permanência dos estudantes indígenas na Universidade}

As políticas públicas referentes à educação, inclusive em nível superior estão inexoravelmente ligadas ao binômio acesso e permanência: não basta só o acesso do estudante de origem popular, é preciso assegurar a permanência destes na Universidade. Pesquisas desenvolvidas pelo FONAPRACE - Fórum de Pró-Reitores de Assuntos Estudantis e Comunitários $(1997 ; 2004)$ informam da necessidade de articulação de ações na perspectiva da assistência estudantil: a permanência e a conclusão do curso por parte dos alunos e alunas em situação de vulnerabilidade socioeconômica, na perspectiva de inclusão social, melhoria do desempenho acadêmico e qualidade de vida.

Daí a necessidade de se produzir reflexões a respeito do acesso e permanência de estudantes indígenas no ensino superior como estratégia política que aliada a outros mecanismos têm a possibilidade de contribuir no debate de projetos em uma perspectiva futura para as comunidades indígenas. Penso que, sobretudo tem o desafio de se transformarem em espaços radicalmente interculturais:

Nossas universidades continuam sendo um deserto com relação aos povos indígenas. Precisamos indianizar nossas bibliotecas, restaurar a pedagogia da oralidade, criar novos cursos, forçar mudanças curriculares, a partir da presença e luta dos povos indígenas na Universidade. Se a Universidade tem sido tradicionalmente uma "fabrica de brancos" - entra índio e sai branco, é possível subverter essa realidade de 
homogeneização e monolitismo. É possível e necessário a construção de uma outra universidade, não para os índios, mas dos índios ${ }^{41}$.

Em nosso entendimento, a implantação do curso de Licenciatura em Educação Básica Intercultural na UNIR, requer da Universidade um repensar do seu jeito de ensinar e aprender, bem como de suas metodologias de ensino. É preciso rever o modelo de fragmentação do saber, a hegemonia do conhecimento acadêmico que se materializa em nosso cotidiano pedagógico, buscando incessantemente a construção do diálogo entre os saberes em uma perspectiva intercultural para que a Universidade assuma sua feição diferenciada:

\begin{abstract}
A escola, em todos os níveis, da aldeia à universidade, foi colocada para nos dominar, deixarmos de ser índios, perder nossa identidade, direitos, nossas terras e recursos naturais. A Universidade não tem sido diferente. Conservadora, formadora das elites dominadoras, ela tem sido um espaço de discriminação e fechado para os povos indígenas, até pouco tempo. Depois de muita luta, finalmente, parece que o acesso, permanência e transformação está em curso. Mas ainda tem um longo caminho a percorrer. Quem sabe milhares de indígenas aos poucos consigam subverter esse espaço fazendo o que fizeram com a maioria das escolas: de mecanismos de opressão foram transformados em instrumentos de fortalecimento da identidade, dos direitos e das lutas das comunidades e povos indígenas ${ }^{42}$.
\end{abstract}

No decorrer da discussão, elaboração e aprovação do curso para os indígenas, observamos que a Universidade explicita uma série de tensões, decorrentes talvez dos desafios em considerar o conhecimento a partir da diferença e de outras lógicas epistemológicas, não produzidas pela cultura ocidental, imposta como condição única de compreensão e concepção de mundo. Diante disso, indagamos: que Universidade aguarda os estudantes indígenas em Rondônia?

Neste debate, arrisco a responder que o contexto universitário que os indígenas vão encontrar tem a ver com descobertas, debates conceituais, instabilidades de cunho epistemológico e metodológico que apontam para a necessidade de se pensar questões desafiadoras, tais como: a relação entre as culturas locais e as culturas universais, o espaço acadêmico e o espaço da aldeia e outros com vistas a possível reelaboração do conhecimento. Mas, certamente um espaço de construção de aprendizagem para todos e todas através do esforço intercultural, conforme afirma o professor Otoniel, da aldeia Tey'kue:

Como acadêmicos entendemos mais algumas coisas e com as lideranças temos força para lutar, porém, a universidade não está preparada para nos receber. Por isso criamos nosso curso, o Teko Arandu, quando entendemos os dois lados, o do karaí (branco) e o nosso, ninguém nos segura. Esse é o nosso desafio ${ }^{43}$.

Uma outra preocupação diz respeito à necessidade de se pensar a vinculação entre os estudantes indígenas e as suas comunidades, para não acontecer do indígena se formar e com isso se distanciar de seu povo. Daí ser necessário, buscar cada vez mais o diálogo e a articulação entre as comunidades indígenas e os alunos e alunas, a partir do ingresso na Universidade até sua formação e retorno à aldeia. Neste sentido, a fala de uma liderança indígena da etnia Gavião por ocasião de uma reunião do Núcleo de Educação Indígena de JiParaná-RO, evidencia importantes aspectos dessa discussão:

\footnotetext{
${ }^{41}$ BRASIL. Os Povos Indígenas e as Universidades: o difícil caminho da descolonização. Disponível em: http://historia.seed.pr.gov.br/modules/noticias/article.php?storyid=20. Acesso em 20/10/2008.

${ }^{42}$ BRASIL. Os Povos Indígenas e as Universidades, ref. IV.

${ }^{43}$ BRASIL. Os Povos Indígenas e as Universidades, ref. IV
} 
Não é porque uso coisa do branco que vou perder minha cultura. Tem índio fazendo faculdade. Será que vão repassar para a comunidade? O nosso objetivo é fortalecer a educação diferenciada para que depois de conhecer a cultura do branco o índio retorne para a aldeia e use seus conhecimentos, sua formação em benefício do seu povo. $(\mathrm{H}$. G. NEI. Ata No. 05 de 2006)

Por fim, é necessário nos aproximarmos na condição de Universidade iniciante das experiências de outras instituições do ensino superior, para que com a possibilidade da troca, possamos ajustar nossas propostas e apontarmos a partir das demandas colocadas pelas comunidades indígenas os projetos de futuro. A necessidade permanente entre a Universidade e as comunidades indígenas pode ajudar a evitar ou minimizar situações como as descritas por Wilson Matos, advogado indígena Terena-Guarani: "Há 20 anos não tínhamos gente formada na Universidade e conquistamos bastante coisa. A Faculdade leva ao emprego e não à luta", ou ainda:

\begin{abstract}
Não se pode ter ilusões. Muita luta será necessária para a conquista de mudanças profundas nas universidades, para que se chegue a uma educação verdadeiramente intercultural, de mão dupla, e se transforme isso em políticas públicas em todas as instâncias, levando a uma efetiva ressignificação da universidade. Isso irá exigir muito debate, organização, rebeldia e coragem histórica. Essas conquistas serão fruto da luta do movimento indígena e seus aliados, da presença indígena nas Universidades e de uma ampla articulação nacional e continental ${ }^{44}$.
\end{abstract}

Uma preocupação futura presente na pauta de alguns setores da UNIR mais próximos da questão indígena, diz respeito ao acesso aos outros cursos, tendo em vista, especialmente, a formação técnica em áreas como administração, contabilidade, direito, saúde, ciências agrárias, e outras. Observamos que diversas universidades públicas, atentas às demandas indígenas por ensino superior, vêm oportunizando interessantes experiências no âmbito do acesso diferenciado dos povos indígenas aos espaços acadêmicos.

Nesta perspectiva, a Fundação Universidade Federal de Rondônia aprovou no âmbito do REUNI (2008) no tópico referente às políticas de inclusão, prevendo: "A ampliação de matrículas por meio de reserva de vagas para minorias étnicas. A partir do vestibular 2009 previsão de 02 vagas por cursos da UNIR para os povos indígenas". Resta a Universidade aprofundar o diálogo com as comunidades indígenas de Rondônia no intuito de atender as demandas por ensino superior desses e de outros segmentos, no entanto considerando seus saberes e processos sociais e históricos diferenciados.

Uma outra medida que tem favorecido o acesso dos povos indígenas pelo menos em um primeiro estágio, ampliando possibilidades de chances é a isenção total da taxa do vestibular. No ano de 2008, só em Porto Velho 38 estudantes indígenas foram beneficiados. Isso porque não incluímos os candidatos do vestibular diferenciado. Desde 2007 a Unir Campus de Porto Velho mantém um Projeto de Apoio Pedagógico aos estudantes indígenas dos anos finais do ensino fundamental e planeja de comum acordo com a FUNAI e os indígenas que já concluíram o ensino médio, o Pré-Vestibular Intercultural. Há pelo menos 32 inscrições, a EEEFM Castelo Branco, parceira no Projeto viabilizará uma sala a noite e a Universidade financiará os bolsistas. A referida atividade ainda não foi iniciada em função da dificuldade de deslocamento por parte dos estudantes.

Pensar as relações entre a Universidade e as Comunidades Indígenas através da Interculturalidade, considerando toda a trajetória histórica destas duas personagens, é algo

\footnotetext{
${ }^{44}$ BRASIL. Os Povos Indígenas e as Universidades, ref. IV
} 
extremamente desafiador. Mas, sabemos que a Fundação Universidade Federal de Rondônia, ao atender as reivindicações dos povos indígenas, cumpre uma etapa estratégica de suas obrigações formativas. Agora, com feição e identidade mais amazônida, enriquecida com todo este processo, pode saudar seus mais novos alunos e alunas indígenas! Sejam bem vindos e bem vindas nesta instituição, que possamos aprender e ensinar juntos nesta caminhada!

\section{Referências}

BECKER, Berta. Fronteira Amazônica: questões sobre a gestão do território. Rio de Janeiro: Editora Universidade Federal do Rio de Janeiro, 1990.

BRASIL. Constituição da República Federativa. (edição atualizada), 1988. Diretrizes e Bases da Educação Nacional. Lei 9394. Brasília, 1996. Plano Nacional de Educação. Lei 10. 172. Brasília, 2001.

BRASIL. Os Povos Indígenas e as Universidades: o difícil caminho da descolonização. Disponível em: http://historia.seed.pr.gov.br/modules/noticias/article.php?storyid=20. Acesso em 20 10/10/2008.

FLEURI, Reinaldo Matias. Intercultura e Educação. Disponível em: http://www.mover.ufsc.br/html/FLEURI_2003_Intercultura_e_Educacao Acesso 10/10/2008.

INDÍGENAS reivindicam curso superior. Jornal Folha de Rondônia. $3^{a}$ feira, 8 de abril de 2008, Ji-Paraná-RO.

LAPLANTINE, François. Aprender Antropologia. São Paulo: Brasiliense, 1994.

MARTINS, Edílson. Nossos Índios, nossos mortos: reportagens, entrevistas e artigos. 2. ed. Editora CODECRI, 1979.

GTA. Grupo de Trabalho Amazônico. Regional Rondônia. O fim da floresta? Porto Velho, 2008.

PERDIGÃO, Francinete; BASSEGIO, Luiz. Migrantes Amazônicos: Rondônia, a trajetória da ilusão. São Paulo: Loyola,1992.

PREZIA, Benedito; HOORNAERT, Eduardo. Brasil indígena: 500 anos de resistência. São Paulo: FTD, 2000.

RONDÔNIA. Fundação Universidade Federal de Rondônia. REUNI. Disponível em: http://www.unir.br/reuni arquivos/UNIR PROJETO REUNI.pdf Acesso 10/10/2008.

RIBEIRO, Darcy. O Povo Brasileiro: a formação e o sentido do Brasil. São Paulo: Companhia das letras, 1995.

SOMOS todos índios. Vinícius Cantuária; Evandro Mesquita. Disponível em: http://letras.terra.com.br/vinicius-cantuaria/628213/corrigir.php. acesso em 10/10/2008.

SILVA, Amizael Gomes da. No rastro dos pioneiros: um pouco da história rondoniana. Porto Velho: SEDUC, 1984. 


\section{Sobre as autoras e os autores}

\section{Bianca Santos Chisté}

Licenciada em Pedagogia, Especialização em Alfabetização e Mestrado em Ciências da Linguagem (2009) pela Universidade Federal de Rondônia (UNIR). Professora da Universidade Federal de Rondônia - Campus de Vilhena. Desenvolve pesquisas junto aos grupos de Pesquisa: Grupo de Estudos e Pesquisas em Psicologia e Educação na Amazônia (GEPPEA) e Grupo de Estudos Pedagógicos (GEP) e Grupo de Estudos e Pesquisas Sociolingüísticas (GEPS). E-mail: bia_chiste@yahoo.com.br

\section{Corinta Maria Grisolia Geraldi}

Graduada em Pedagogia pela Faculdade de Filosofia Ciências e Letras de Santo Ângelo. Mestre e Doutora em Educação pela Universidade Estadual de Campinas - UNICAMP. Professora da UNICAMP, onde participa do Grupo de Estudos e Pesquisas sobre Educação Continuada - GEPECIFE/Unicamp. E-mail: corintageraldi@yahoo.com.br e gepec@unicamp.br

\section{Edna Maria Cordeiro}

Pedagoga com habilitação em supervisão escolar e docência pela Universidade Federal de Rondônia (UNIR). Mestre em Educação pela Universidade Lusófona de Humanidades e Tecnologias (ULHT). Professora no Curso de Pedagogia da UNIR - Campus de Vilhena. Desenvolve pesquisas junto ao Grupo de Estudos Pedagógicos (GEP) e GEPS - Grupo de Estudos e Pesquisas Sociolingüísticas. E-mail: cordeiroedna@unir.br

\section{Flávia Pansini}

Licenciada em Pedagogia pela Fundação Universidade Federal de Rondônia (UNIR). Mestre em Ciências da Linguagem pela Universidade Federal de Rondônia. Professora do Departamento de Educação da UNIR - Campus de Rolim de Moura. Desenvolve pesquisas junto ao Grupo de Estudos e Pesquisas em Psicologia e Educação na Amazônia (GEPPEA). E-mail: flaviapansini3@yahoo.com.br

Josélia Gomes Neves

Licenciada em Pedagogia (UNIR). Mestre em Desenvolvimento Regional e Meio Ambiente (UNIR). Doutora em Educação Escolar (UNESP). Docente do Curso de Pedagogia da UNIR Campus de Ji-Paraná. Líder do Grupo de Pesquisa em Educação da Amazônia (GPEA) Email: joshiva42@gmail.com 


\section{Juliane Oliveira}

Graduação em Pedagogia pela Fundação Universidade Federal de Rondônia (UNIR). Desenvolve pesquisas junto ao Grupo de Estudos Pedagógicos (GEP). E-mail: crisanjo@hotmail.com

\section{Juracy Machado Pacífico}

Licenciada em Pedagogia pela Fundação Universidade Federal de Rondônia (UNIR). Mestre em Psicologia Escolar pela Universidade de São Paulo (USP). Doutoranda em Educação Escolar pela Universidade Estadual Paulista. (UNESP). Professora no Curso de Pedagogia da UNIR - Campus de Vilhena. Desenvolve pesquisas junto ao Grupo de Estudos Pedagógicos (GEP). E-mail: ju.mapa@hotmail.com

\section{Klésia Regina Gregória Prudente}

Graduação em Pedagogia pela Fundação Universidade Federal de Rondônia (UNIR). Desenvolve pesquisas junto ao Grupo de Estudos Pedagógicos (GEP). E-mail: klesiaprudente@hotmail.com

\section{Luzenir da Mota Alves}

Licenciada em Pedagogia, Especialização em Alfabetização pela Universidade Federal de Rondônia. Professora da Rede Estadual de Rondônia. Atualmente exercendo a função de coordenação pedagógica na Representação de Ensino em Rolim de Moura. Desenvolve pesquisas junto ao Grupo de Estudos e Pesquisas em Psicologia (GEPPEA). E-mail: luzenir@brturbo.com.br

\section{Maria Cândida Müller}

Licenciada em Matemática pela Universidade Federal do Rio Grande do Sul (UFRGS). Mestre e Doutora em Educação pela Universidade Estadual de Campinas (UNICAMP). Docente do Curso de Pedagogia da UNIR - Campus de Vilhena. Desenvolve pesquisas junto ao Grupo de Estudos Pedagógicos (GEP) e atualmente é líder do Grupo. Também participa do Grupo de Estudos e Pesquisas Sociolingüísticas (GEPS). E-mail: maria.candida@unir.br.

\section{Maria Ivonete Barbosa Tamboril}

Graduada em pedagogia pela Fundação Universidade Federal de Rondônia (UNIR). Mestra e Doutora em Psicologia pela Universidade de São Paulo (USP). Professora do Departamento de Psicologia e do Programa de Mestrado Acadêmico em Psicologia (MAPSI) da UNIR Campus José Ribeiro Filho (Porto Velho-RO). Desenvolve pesquisas junto ao Grupo de Estudos Pedagógicos (GEP). ivabt@uol.com.br.

\section{Marilsa Miranda de Souza}

Licenciada em Pedagogia e Bacharel em Direito pela Universidade Federal de Rondônia (UNIR). Mestre em Desenvolvimento Regional e Meio Ambiente (UNIR). Doutoranda em Educação Escolar pela Universidade Estadual Paulista-UNESP. Professora do Departamento de Educação - UNIR/Campus de Rolim de Moura. Desenvolve pesquisas junto ao Grupo de Estudos e Pesquisas em Psicologia e Educação na Amazônia (GEPPEA) e Grupo de Estudos 
e Pesquisas Materialismo Histórico e Dialético na Educação (GEPMHDE). E-mail: msmarilsa@hotmail.com

\section{Marli Lúcia Tonatto Zibetti}

Pedagoga e doutora em Psicologia Escolar e do Desenvolvimento Humano pelo Instituto de Psicologia da Universidade de São Paulo. Professora do Departamento de Educação UNIR/Campus de Rolim de Moura. Coordena o GEPPEA: Grupo de estudos e pesquisas em Psicologia e Educação na Amazônia. Desenvolve pesquisas no campo da aprendizagem, saberes docentes e prática pedagógica. E-mail: marlizibetti@yahoo.com.br

\section{Neide Borges Pedrosa}

Graduada em Pedagogia, especialista em Informática Aplicada à Educação, Mestre em Ciências e Práticas Educativas pela Universidade de Franca, UNIFRAN. Atualmente está cursando Doutorado em Educação na área de currículo - PUC/SP. Professora assistente da Fundação Universidade Federal de Rondônia/ Campus de Ji-Paraná. Desenvolve pesquisas junto ao Grupo de Pesquisa em Educação da Amazônia - GPEA. E-mail: neibp@bol.com.br

\section{Orestes Zivieri Neto}

Doutor em Educação Escolar pela UNESP. Vice-líder do Grupo de Estudos e Pesquisas em Psicologia e Educação da Amazônia. Professor do Departamento de Educação da Fundação Universidade Federal de Rondônia - Campus de Rolim de Moura - RO. E-mail: orestesz@hotmail.com

\section{Paulo Roberto Padilha}

Mestre e doutor em Educação pela FE-USP, pedagogo, músico e Diretor do IPF. Autor dos livros: Educar em Todos os Cantos (São Paulo: Cortez/IPF, 2007), Currículo intertranscultural (São Paulo: Cortez/IPF, 2004), Planejamento dialógico (São Paulo: Cortez/IPF, 2001). Publicou também Município que Educa: nova arquitetura da gestão pública. São Paulo: Editora e Livraria Instituto Paulo Freire, 2009. (Caderno de Formação, 2) e Educação Cidadã, Educação Integral: fundamentos e práticas. São Paulo: Editora e Livraria Instituto Paulo Freire, 2010. (Educação Cidadã, 6). E-mail: padilha@paulofreire.org

\section{Reinaldo Matias Fleuri}

Doutor em Educação pela Universidade Estadual de Campinas (1988) realizou estágios de pós-doutorado na Università degli Studi di Perugia, Itália (1996), na Universidade de São Paulo (2004) e na Universidade Federal Fluminense (2010). Professor titular da Universidade Federal de Santa Catarina. E-mail: rfleuri@gmail.com 
